\title{
ANALISIS EKONOMI POLITIK PEMENUHAN HAK-HAK PEKERJA MIGRAN ASAL SULAWESI SELATAN DI MALAYSIA
}

ANALYSIS OF POLITICAL ECONOMY ON FULFILLMENT OF THE RIGHTS OF MIGRANT WORKERS FROM SOUTH SULAWESI

IN MALAYSIA

TESIS

Diajukan Untuk Memenuhi Persyaratan Magister pada Program Studi IImu Politik Universitas Hasanuddin

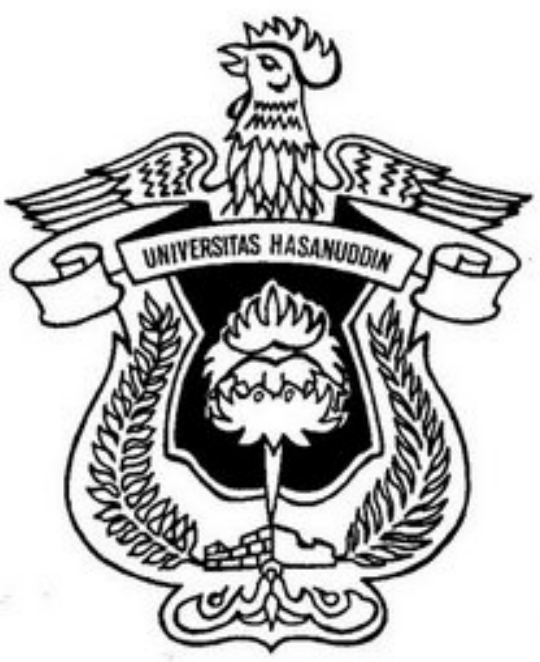

ACHMAD ZULFIKAR P4300214011

PASCASARJANA ILMU POLITIK FAKULTAS ILMU SOSIAL DAN ILMU POLITIK UNIVERSITAS HASANUDDIN 2016 
遂) (图)

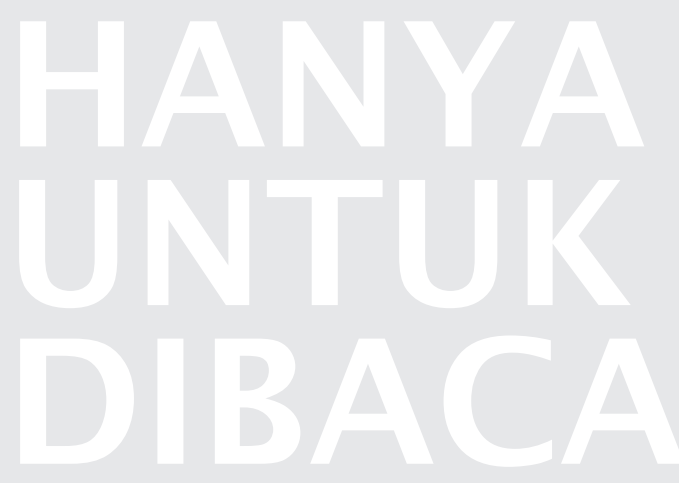




\section{TESIS}

\section{ANALISIS EKONOMI POLITIK PEMENUHAN HAK-HAK PEKERJA MIGRAN ASAL SULAWESI SELATAN DI MALAYSIA}

\section{Disusun dan diajukan oleh ACHMAD ZULFIKAR}

Nomor Pokok P4300214011

telah dipertahankan di depan Panitia Ujian Tesis

pada tanggal 22 Agustus 2016

dan dinyatakan telah memenuhi syarat

\section{Menyetujui}

Komisi Penasihat

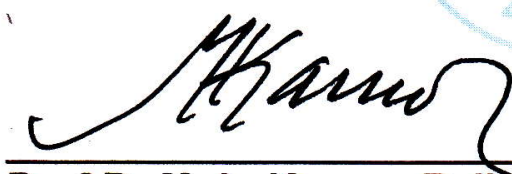

Prof.Dr.Muh. Kausar Bailusy, MA. Ketua

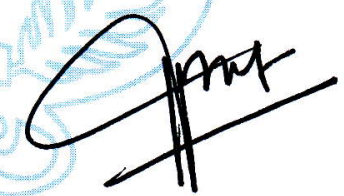

Dr. Gustiana, S.IP., M.Si. Anggota

Ketua Program Studi IImu Politik,
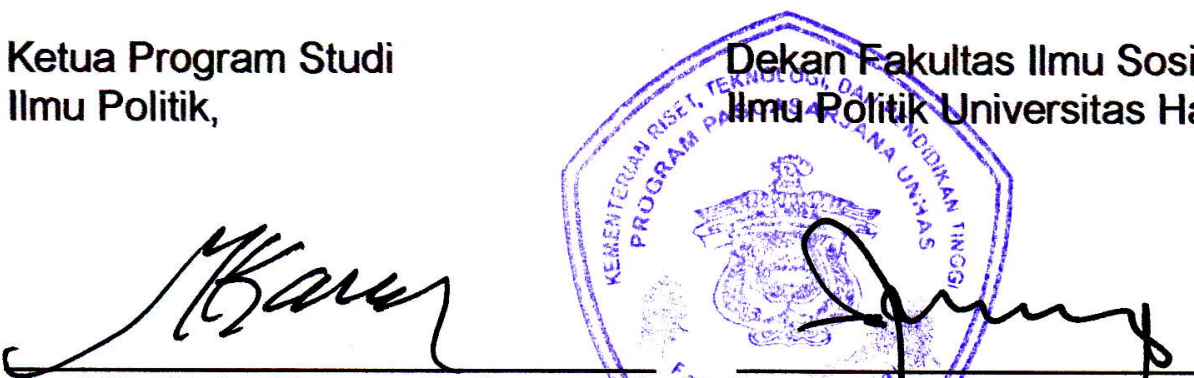

Prof.Dr.Muh. Kausar Bailusy, MA. Prof. Dr. A/Alimuddih Unde, M.Si.

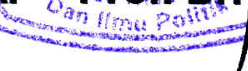




\begin{abstract}
ABSTRAK
ACHMAD ZULFIKAR. Analisis Ekonomi Politik Pemenuhan Hak-hak Pekerja Migran Asal Sulawesi Selatan di Malaysia (dibimbing oleh Muh. Kausar Bailusy dan Gustiana A. Kambo).

Penelitian ini bertujuan (1) menggambarkam pemenuhan hak-hak pekerja migran asal Sulawesi Selatan di Malaysia berdasarkan UU No. 39 Tahun 2004 pada masa prapenempatan dan (2). menggambarkan pemenuhan hak-hak pekerja migran asal Sulawesi Selatan di Malaysia berdasarkan UU No. 39 Tahun 2004 pada masa penempatan.

Penelitian ini dilaksanakan di Provinsi Sulawesi Selatan, Indonesia dan Tawau, Sabah, Malaysia. Metode yang digunakan adalah kualitatif dengan pendekatan studi kasus. Data diperoleh melalui wawancara dan studi pustaka. Data dianalisis menggunakan teknik reduksi data, penyajian data, dan penarikan kesimpulan.

Hasil penelitian menunjukkan bahwa pemenuhan hak-hak pekerja migran asal Sulawesi Selata di Malaysia pada masa prapenempatan dan masa penempatan yang dilaksanakan dengan benar akan signifikan bagi peningkatan ekonomi tenaga kerja Indonesia/pekerja migran Indonesia (TKI/PMI), negara penempatan (Malaysia) dan negara asal (Indonesia). Semakin tinggi tingkat pemahaman seseorang terkait prosedur yang legal, semakin berkurang TKI/PMI yang menempuh jalur ilegal/nonprosedural.
\end{abstract}

Kata kunci: ekonomi politik, hak asasi manusia, pekerja migran, Sulawesi Selatan, Malaysia

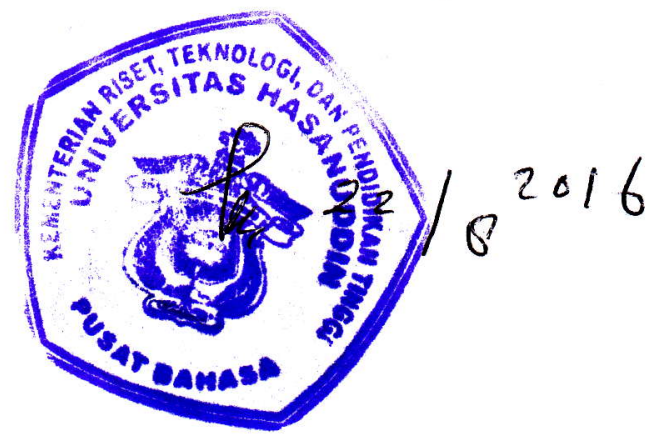




\section{ABSTRACT}

ACHMAD ZULFIKAR. Analysis of Political Economy on Rights Fulfillment of Migrant Workers from South Sulawesi in Malaysia (Supervised by Muh. Kausar Bailusy and Gustiana A. Kambo).

The aims of this research were (1) to describe and analyze rights fulfillment of migrant workers from South Sulawesi in Malaysia based on Regulations No. 39 Year 2004 prior to placement; (2) to describe and analyze rights fulfillment of migrant workers from South Sulawesi in Malaysia based on Regulations No. 39 Year 2004 after the placement.

The research was carried out in South Sulawesi Province of Indonesia and Tawau, Sabah, Malaysia. The research employed a qualitative method and a case study approach. Data were gathered through interviews and library research. Data were analyzed using data reduction technique, data presentation, and conclusion drawing.

The results showed that the right fulfillment of migrant workers from South Sulawesi in Malaysia both during pre placement and after placement contributed significantly to economic improvement of Indonesian migrant workers (TKI/PMI). This improvement benefited both Indonesia as supplying country and Malaysia as placement country. The better the awareness regarding legal procedure the smaller the chance for the migrants/workers to make use of illegal procedure.

Key words: Political economy; human rights; migrant workers; South Sulawesi; Malaysia

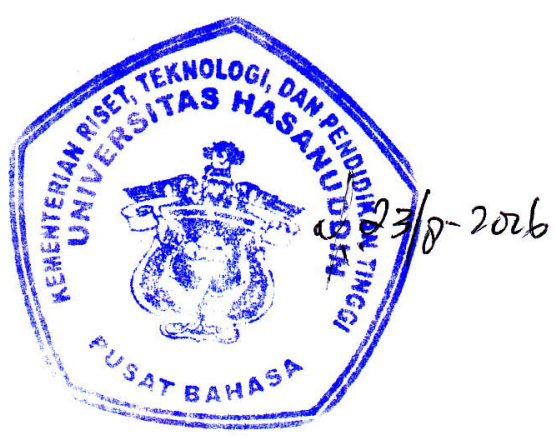




\section{PERNYATAAN KEASLIAN TESIS}

Yang bertanda tangan di bawah ini:

Nama : Achmad Zulfikar

NIM $\quad$ : P4300214011

Program Studi $\quad$ : Ilmu Politik

Menyatakan dengan s ebenarnya $b$ ahwa $t$ esis yang $s$ aya $t$ ulis i ni be nar-benar merupakan ha sil ka rya s aya s endiri, bu kan m erupakan pe ngambilalihan tulisan a tau pemikiran ora ng lain. A pabila di kemudian ha ri terbukti a tau da pat dibuktikan bahwa sebagian a tau ke seluruhan t esis i ni ha sil ka rya ora ng 1 ain, s aya be rsedia menerima sanksi atas perbuatan tersebut.

Makassar, 22 Agustus 2016

Yang menyatakan,

signed

Achmad Zulfikar 


\section{KATA PENGANTAR}

\section{Assalamu alaikum wr wb.}

Puji dan syukur penulis panjatkan ke hadirat Allah SWT atas rahmat dan karunia-Nya, serta shalawat dan salam penulis haturkan kepada Nabi Muhammad SAW yang telah membawa ummatnya kepada era pencerahan dari zaman kejahiliahan.

Alhamdulillah, penulis haturkan atas terselesaikannya Tesis berjudul "Analisis Ekonomi Politik Pemenuhan Hak-Hak Pekerja Migran asal Sulawesi Selatan di Malaysia". Hadirnya tesis ini di tangan pembaca tentu melalui proses panjang mulai dari awal studi penulis hingga penyelesaian studi yang melibatkan banyak pihak.

Oleh karena itu, melalui kata pengantar ini penulis menyampaikan penghargaan yang setinggi-tingginya kepada Ibunda Sitti Rabiah yang telah memberikan dukungan materiil, moril dan spiritual kepada penulis sehingga kesempatan untuk melanjutkan studi di jenjang Magister dapat terwujud hingga dapat penulis selesaikan. Selanjutnya kepada Ayahanda Baharuddin Nur, adikadik Akbar, Chaedar dan Kautsar yang senantiasa memberi semangat. Penulis juga menyampaikan penghargaan dan terima kasih kepada:

1. Ibu Prof. Dr. Dwia Tina Aries Pulubuhu, M.A. selaku Rektor Universitas Hasanuddin

2. Bapak Prof. Dr. Muhammad Ali, S.E., M.S. selaku Dekan Sekolah Pascasarjana Universitas Hasanuddin 
3. Prof. Dr. Andi Alimuddin Unde, M.Si. selaku Dekan Fakultas IImu Sosial dan IImu Politik Universitas Hasanuddin

4. Direktur Utama Lembaga Pengelola Dana Pendidikan yang telah memberikan pendanaan Beasiswa Tesis melalui perjanjian No. PRJ507/LPDP.3/2016

5. Prof. Dr. Muh. Kausar Bailusy, M.A. selaku Pembimbing I dan juga Ketua Program Studi (S2) Ilmu Politik Universitas Hasanuddin dan Dr. Gustiana A. Kambo, M.Si. selaku Pembimbing II dan juga Wakil Dekan I FISIP Universitas Hasanuddin. Terima kasih atas arahan dan bimbingan dari Prof dan Ibu dari awal menggagas ide hingga penyelesaian tesis. Serta didikan selama menjadi mahasiswa di S2 IImu Politik UNHAS.

6. Prof. Dr. Armin, M.Si., Dr. Nurlinah, M.Si. dan Muhammad Nasir Badu, Ph.D. selaku Penguji. Terima kasih atas masukan-masukan yang diberikan.

7. Seluruh dosen pengajar di S2 Ilmu Politik UNHAS, Prof. Dr. Mappa Nasrun, M.A., Prof. Dr. Muh. Kausar Bailusy, M.A., Prof. Dr. Juanda Nawawi, M.S., Prof. Dr. Armin, M.Si., Prof. Dr. Gau Kadir, M.A., Prof. Dr. M. Basir Syam, M.Ag., Dr. Muhammad Saad, M.A., Dr. Gustiana A. Kambo, M.Si., Dr. A. Samsu Alam, M.Si., Dr. Jayadi Nas, M.Si., Dr. Adi Suryadi Culla, M.A., Dr. Suryadi Lambali, M.A., Muhammad Nasir Badu, Ph.D. dan Drs. A. Yakub, M.Si. Terima kasih atas ilmu 
yang telah dibagikan Prof, Bapak dan Ibu, semoga menjadi amal jariah dan bermanfaat.

8. Keluarga Pasca Ilmu Politik Angkatan 2014 yang telah bersama menjalani perkuliahan: Ibu Fitriani, Kak Abdul Chalid (Boim), Kak Ghalib Alydrus, Bu Nurfadilah Nasiruddin, Bu Citra N. Fariaty, Bro Hardiman Wirahmat, Kak Nur Alfiyani, Bu Nurul Fibrianti (Lulu), Bung Aswar Thahir, Kanda Mattewakkan, Bung Muhammad Ridwan, Kak Nurlira Goncing, Kak Andi Fahry Makkasau, Bung Babra Kamal. Semoga tali persaudaran diantara kita tetap terjalin erat.

Penulis juga menyampaikan penghargaan dan terima kasih kepada seluruh informan penelitian:

1. Bapak R.Soes Hindharno, S.H., Direktur Jenderal Penempatan dan Perlindungan Tenaga Kerja Luar Negeri, Kemenaker RI

2. Bapak Krishna Djelani, Kepala Subdirektorat Pengawasan Kekonsuleran, Direktorat Perlindungan WNI dan BHI, Kemlu RI.

3. Bapak R. Wisantoro, Direktur Media dan Advokasi, Deputi III Bidang Perlindungan, BNP2TKI.

4. Bapak Dr. Syahrul Yasin Limpo, S.H., M.H., M.Si., Gubernur Sulawesi Selatan

5. Bapak Drs. H. Andi Marzkui Wadeng, Ketua Komisi E Dewan Perwakilan Rakyat Daerah (DPRD) Provinsi Sulawesi Selatan

6. Bapak Mohd. Agus Bustami, S.E., M.M., Kepala Balai Pelayanan Penempatan dan Perlindungan Tenaga Kerja Indonesia (BP3TKI) 
Makassar serta Ibu Tenri Ulleng, S.S., M.Pd., Kasi Penyiapan Penempatan, Ibu Nurmiati, S.Sos., M.M., Kasi Kelembagaan dan Pemasyarakatan Program, Ibu Imrana Syatar, S.E., M.M., Kasi Perlindungan dan Pemberdayaan, dan Bapak Zulkifli, S.E., Koordinator P4TKI Pare-Pare

7. Bapak Edy Sudjarwo, Kepala BP3TKI Nunukan dan Bapak Sigit Triwibawanto, S.E., Kasi. Perlindungan dan Pemberdayaan.

8. Konsulat Republik Indonesia di Tawau, Malaysia: Ibu Dian Ratri Astuti, Kepala Kanselerai/Fungsi Pensosbud, Bapak Prakoso Wicaksono, Fungsi Ekonomi dan Protokol Kekonsuleran dan Bapak Ujo Sujoto, Staf Teknis Imigrasi.

9. Bapak Suhaili bin Ismail, Senior Assistant Director, Pejabat Tenaga Kerja Tawau, Jabatan Tenaga Kerja Sabah, Kementerian Sumber Manusia, Malaysia

10. Ibu Mike Verawati, Project Officer Advokasi Buruh Migran berbasis Teknologi, LSM Migrant Care.

11. Bapak Dr. Syamsi Alang, M.M., Koordinator Fungsional Pengantar Kerja, Dinas Tenaga Kerja dan Transmigrasi Provinsi Sulawesi Selatan.

12. Bapak Andi Iskandar, Kepala Seksi Perluasan Kerja, Dinas Tenaga Kerja dan Transmigrasi Kota Makassar

13. Bapak Yusran, S.Pd., Kepala Bidang Penempatan Tenaga Kerja, Dinas Tenaga Kerja Kota Pare-Pare 
14. Bapak Mustamin Raga, Dinas Tenaga Kerja dan Transmigrasi Kabupaten Gowa

15. Ibu Andi Nagauleng, S.E., Direktur Utama PT. Amalindo Bhakti Persada, Pare-Pare (PPTKIS)

16. Ibu Kartini Baharuddin F., S,Ag, Kepala Kantor Konsorsium Asuransi Tenaga Kerja Indonesia (ASTINDO) Perwakilan Daerah Sulawesi Selatan

17. Bapak Mostyn bin Marsuki, Direktur Agensi Pekerjaan Mospia dan Ibu Mustaslifah binti Mostyn, Bagian Pengurusan Agensi Pekerjaan Mospia, Tawau, Malaysia..

Penulis mengucapkan terima kasih dan permohonan maaf kepada pihakpihak yang telah membantu dalam penyusunan tesis ini namun tidak dapat disampaikan satu per satu dalam kata pengantar ini. Semoga bantuan yang telah diberikan bernilai pahala di sisi Tuhan Yang Maha Esa.

Mengakhiri kata pengantar ini, penulis menyadari bahwa tesis ini masih perlu banyak masukan dan saran, maka dari itu penulis mengharapkan masukan dan saran konstruktif dari pembaca melalui email apa@kabarfikar.com. Semoga karya ini dapat berguna bagi semua pihak, pengembangan ilmu pengetahuan untuk kemajuan bangsa.

\section{Wassalamu alaikum wr wb.}

Makassar, 22 Agustus 2016 
DAFTAR ISI

Halaman Judul ...............................................................

Halaman Pengesahan ......................................................... ii

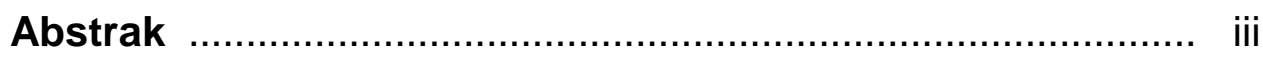

Pernyataan Keaslian Tesis ….............................................

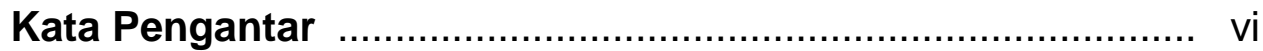

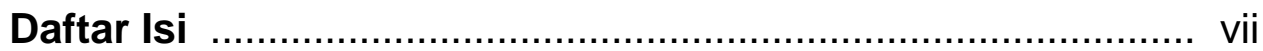

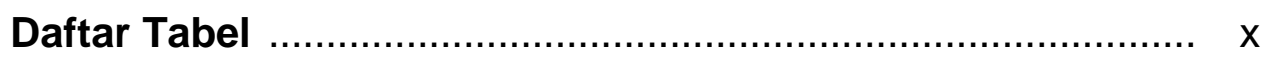

Daftar Grafik, Bagan dan Gambar ......................................... xii

Daftar Lampiran ............................................................... xii

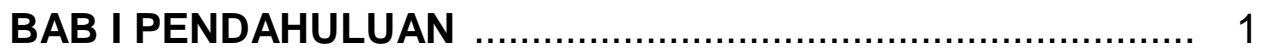

1.1 Latar Belakang Masalah ................................................. 1

1.2 Rumusan Masalah ............................................................ 13

1.3 Tujuan dan Manfaat Penelitian ...................................... 14

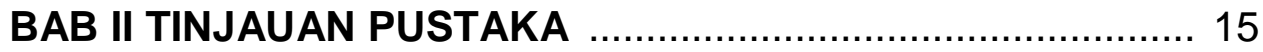

2.1 Perspektif Ekonomi Politik ............................................. 15

2.2 Ekonomi Politik Kelembagaan …………….................. 24

2.2.1 Peran Pemerintah ................................................. 33

2.2.2 Interaksi Pemerintah dan Swasta ........................ 43

2.2.3 Peran Masyarakat Sipil ……………………....... 46

2.3 Ekonomi Politik Sektoral ................................................ 48

2.4 Hak-Hak Pekerja Migran Indonesia ............................... 50

2.5 Hasil Penelitian yang Relevan ……………………...... 75

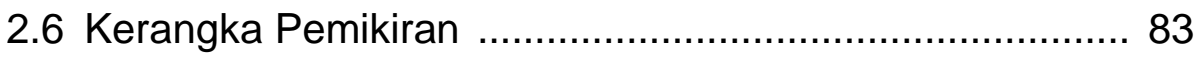


3.1 Tipe dan Dasar Penelitian .......................................... 86

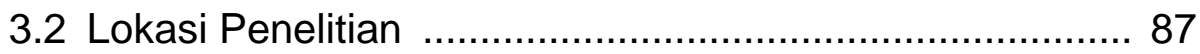

3.3 Sumber Data ........................................................... 88

3.4 Teknik Pengumpulan Data ................................... 88

3.5 Teknik Analisis Data ................................................ 92

3.5.1 Reduksi Data ............................................... 89

3.5.2 Penyajian Data ............................................ 94

3.5.3 Penarikan Kesimpulan .................................... 95

BAB IV GAMBARAN OBJEK PENELITIAN _........................ 97

4.1 Statistik Penempatan dan Negara Tujuan Pekerja

Migran Indonesia ............................................. 97

4.2 Pemetaan Masalah Pekerja Migran Indonesia ...............101

4.3 Statistik Pengaduan Pekerja Migran Indonesia .............106

4.4 Struktur UU No. 39 Tahun 2004 ..................................110

BAB V HASIL DAN PEMBAHASAN .................................112

5.1 Pemenuhan Hak-Hak Pekerja Migran Indonesia asal Sulawesi Selatan pada Masa Pra-Penempatan .......112

5.1.1 Peran Pemerintah ........................................112

5.1.2 Interaksi Pemerintah dan Swasta ......................124

5.1.3 Peran Masyarakat Sipil ...................................149

5.2 Pemenuhan Hak-Hak Pekerja Migran Indonesia asal Sulawesi Selatan di Malaysia pada Masa Penempatan ...........................................156

5.2.1 Peran Pemerintah .........................................156

5.2.2 Interaksi Pemerintah dan Swasta ......................168

5.2.3 Peran Masyarakat Sipil .......................................183 
BAB VI PENUTUP

191

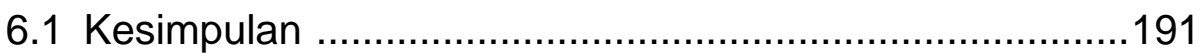

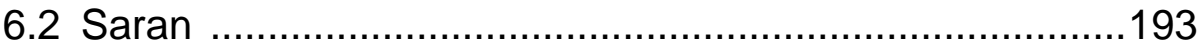

DAFTAR PUSTAKA 


\section{DAFTAR TABEL}

Tabel 2.1 Model-Model Ekonomi Politik dari

Metodologi dan Substansi

Tabel 2.2 Model-Model Interaksi Birokrasi (Pemerintah) dan

Dunia Usaha (Swasta)

Tabel 4.1 Penempatan Tenaga Kerja Luar Negeri Indonesia

Berdasarkan Provinsi Periode 2011-2015

Tabel 4.2 Negara Penempatan Tenaga Kerja Luar Negeri

Indonesia Periode 2011-2015

Tabel 4.3 Jabatan TKI di Negara Penempatan

Periode 2011-2015

Tabel 4.4 Status Pengaduan TKI 2012-2015 107

Tabel 4.5 Pengaduan Berdasarkan Provinsi 2012-2015 107

Tabel 4.6 Pengaduan Berdasarkan Negara Penempatan 2012-2015 108

Tabel 4.7 Pengaduan Berdasarkan Jenis Masalah 2012-2015 ...109

Tabel 5.1 Pengesahan Demand Letter Tahun 2014 dan 2015 ...114

Tabel 5.2 Daftar PPTKIS/Cabang di Prov. Sulawesi Selatan

Tahun 2015

Tabel 5.3 Bayaran Kos Kemasukan Tahun Pertama

Ditanggung Majikan

Tabel 5.4 Data Penempatan TKI ke Luar Negeri Kab/Kota

Se Sulawesi Selatan Tahun 2012-2015 144

Tabel 5.5 Negara Penempatan TKI Tahun 2012-2015

Se Wilayah BP3TKI Makassar (Makassar, Pare-Pare, Mamuju) . 145

Tabel 5.6 Pemenuhan Hak-Hak Pekerja Migran asal Sulsel pada Masa Pra-Penempatan

Tabel 5.7 TKI/WNI Deportasi Berdasarkan Jenis Kelamin

dan Jenis Dokumen 160

Tabel 5.8 TKI/WNI Deportasi Berdasarkan Asal Daerah 161 
Tabel 5.9 Senarai Syarikat di Wilayah Kerja KRI Tawau

Tabel 5.10 Data Tenaga Kerja Indonesia di Malaysia

170

Tabel 5.11 Data Jumlah Buruh (Pekerja) Migran Indonesia dan

Tanggungan di Wilayah Kerja Konsulat RI Tawau 171

Tabel 5.12 Kasus WNI/TKI Bermasalah 2014 dan 2015 173

Tabel 5.13 Pelayanan Bantuan kepada WNI/TKI Bermasalah

Tahun 2014 dan 2015 174

Tabel 5.14 Pelayanan Pengembalian Tuntutan Gaji WNI/TKI .....175

Tabel 5.15 Penanganan Kasus BP3TKI Makassar 2012-2015 ...176

Tabel 5.16 Jumlah Kasus BP3TKI Makassar

di Malaysia 2012-2015

Tabel 5.17 Pemenuhan Hak-Hak Pekerja Migran asal Sulsel pada Masa Pra-Penempatan 


\section{DAFTAR GRAFIK, BAGAN DAN GAMBAR}

Bagan 2.1 Sejarah dan Cabang IImu Ekonomi Politik ................ 17

Bagan 2.2 Model Hierarki Kebijakan Publik ............................... 40

Bagan 2.3 Jenis Klasifikasi Organisasi ...................................... 42

Bagan 2.4 Peta Pemangku Kepentingan Sektoral ....................... 50

Bagan 2.5 Skema Pikir Analisis Ekonomi Politik

Pemenuhan Hak-Hak Pekerja Migran Asal Sulawesi Selatan

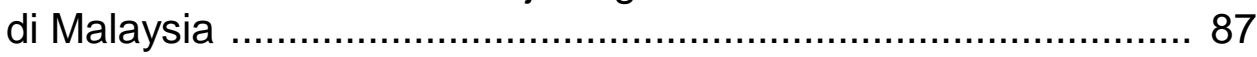

Bagan 3.1 Komponen-Komponen Analisis Data:

Model Interaktif

Grafik 4.1 Penempatan Tenaga Kerja Indonesia

Tahun 2011-2015

Gambar 5.1 Surat Izin Pengerahan dari BNP2TKI

Gambar 5.2 Surat Pengantar Rekrut (SPR) dari

Disnakertrans Sulsel.

Bagan 5.1 Skenario Biaya Rekrutmen ....................................137

Grafik 5.3 TKI/WNI Deportasi dari Malaysia 2012-2015 ..............161 


\section{BAB I}

\section{PENDAHULUAN}

\subsection{Latar Belakang Masalah}

Hak asasi merupakan bagian terpenting yang tidak dapat dipisahkan dari manusia, konsep ini memiliki dasar pijakan yang kokoh dari seluruh budaya dan agama. Pandangan dunia tentang Hak Asasi Manusia (HAM) adalah pandangan kesemestaan bagi eksistensi dan proteksi kehidupan dan kemartabatan manusia. Wacana HAM terus berkembang seiring dengan intensitas kesadaran manusia atas hak dan kewajiban yang dimilikinya. Namun demikian, wacana HAM menjadi aktual karena sering dilecehkan dalam sejarah manusia sejak awal hingga kurun waktu kini. Gerakan dan diseminasi HAM terus berlangsung bahkan dengan menembus batas-batas teritorial sebuah negara. ${ }^{1}$

Hak asasi manusia (HAM) masuk di Indonesia dan diterima, dipahami serta diaktualisasikan dalam bingkai formulasi kebijakan dan perkembangan sosio-politis. Dalam konteks reformasi, pemikiran ke arah bentuk jaminan HAM yang lebih kokoh semakin mendapatkan momentumnya. Perubahan Undang-Undang Dasar (UUD) 1945 adalah fakta sejarah sekaligus diyakini sebagai awal bagi penguatan demokrasi Indonesia yang berbasis perlindungan $\mathrm{HAM}^{2}$ Hak untuk bekerja dipenuhi oleh negara (pemerintah) sebagai tanggungjawab atas jaminan HAM warga negara. Hal ini terdapat pada UUD NRI 1945 pasal 27 ayat (2) yang

\footnotetext{
${ }^{1}$ Majda El Muhtaj. 2013. Dimensi-Dimensi HAM: Mengurai Hak Ekonomi, Sosial dan Budaya. Jakarta: Rajawali Pers. hh. 1-2.

2 Ibid. hh.2-3.
} 
menyatakan bahwa setiap Warga Negara Republik Indonesia berhak atas pekerjaan dan penghidupan yang layak bagi kemanusiaan.

Pemerintah Indonesia yang mengemban tugas untuk memenuhi hak warga negara untuk mendapatkan pekerjaan, saat ini belum mampu untuk menjalankan tugasnya dengan optimal. Rendahnya daya serap lapangan kerja di dalam negeri mengakibatkan terjadinya migrasi pekerja Indonesia ke luar negeri yang pelakunya disebut sebagai Tenaga Kerja Indonesia/Pekerja Migran Indonesia. Migrasi kerja ke luar negeri ini memberikan peluang dan harapan bagi TKI/PMI untuk mendapatkan penghasilan yang lebih besar dan kehidupan yang lebih baik.

Warga negara Indonesia yang mencari pekerjaan ke luar negeri ini mendorong pemerintah untuk merumuskan UU No. 39 Tahun 2004 tentang Penempatan dan Perlindungan Tenaga Kerja Indonesia di Luar Negeri. Hal ini sebagai upaya untuk memastikan bahwa pekerja migrant (TKI/PMI) yang ditempatkan mendapatkan perlindungan yang optimal di negara penempatan. Pada bagian pertimbangan, undang-undang ini menekankan aspek pemenuhan hak-hak asasi manusia sebagai inti dari pelaksanaan penempatan dan perlindungan TKI di luar negeri, selengkapnya sebagai berikut: (a) bekerja merupakan hak asasi manusia yang wajib dijunjung tinggi, dihormati, dan dijamin penegakannya; (b) hak setiap warga negara untuk memperoleh pekerjaam dan penghidupan yang layak baik di dalam maupun di luar negeri sesuai dengan keahlian, keterampilan, bakat, minat, dan kemampuan; (c) tenaga kerja Indonesia yang bekerja ke luar negeri sering dijadikan objek perdagangan manusia, 
kerja paksa, korban kekerasan, kesewenang-wenangan, kejahatan atas harkat dan martabat manusia, serta perlakuan lain yang bertentangan dengan hak asasi manusia; (d) negara wajib menjamin dan melindungi hak asasi warga negaranya yang bekerja baik di dalam maupun di luar negeri berdasarkan prinsip persamaan hak, demokrasi, keadilan sosial, kesetaraan gender, dan anti diskriminasi; (e) penempatan tenaga kerja Indonesia ke luar negeri perlu dilakukan secara terpadu antara instansi Pemerintah baik Pusat maupun Daerah dan peran serta masyarakat dalam suatu produk hukum yang memadai guna memberikan perlindungan yang maksimal.

Pemerintah Indonesia sebagai negara pengirim tenaga kerja juga perlu mempertimbangkan meningkatnya TKI/PMI secara signifikan dari tahun ke tahun. Kepala Desk Diaspora Kementerian Luar Negeri Republik Indonesia menyatakan bahwa pada tahun 2013, warga negara Indonesia (WNI) yang melakukan diaspora (migrasi internasional) diperkirakan mencapai 8-10 juta orang di seluruh dunia. Prakiraan ini termasuk pekerja migran Indonesia yang bekerja ke luar negeri. ${ }^{3}$

Pelaksanaan penempatan dan perlindungan TKI/PMI di luar negeri tidak hanya menjadi tugas pemerintah pusat, tetapi juga menjadi tugas pemerintah daerah asal TKI/PMI. BNP2TKI merilis data penempatan TKI berdasarkan Provinsi menempatkan Provinsi Jawa Barat, Jawa Tengah, Jawa Timur dan Nusa Tenggara Barat (NTB) di posisi empat teratas. Sedangkan Provinsi Sulawesi Selatan berada pada posisi kesepuluh

\footnotetext{
3 Antara News, (2013), Kemlu bentuk 11 Kelompok Kerja Kongres Diaspora http://www.antaranews.com/berita/384634/kemlu-bentuk-11-kelompok-kerja-kongresdiaspora, diakses 22 November 2015.
} 
dengan jumlah TKI/PMI yang ditempatkan cukup signifikan yakni: 13.948 (2011), 13.875 (2012), 10.358 (2013), 7.497 (2014) dan 2.259 (2015 per30 November).

Balai Pelayanan, Penempatan dan Perlindungan Tenaga Kerja Indonesia (BP3TKI) Makassar mencatat Kabupaten/Kota dengan penempatan TKI yang signifikan antara lain: Gowa, Bantaeng, Bulukumba, Jeneponto, Makassar dan Pinrang. Sedangkan negara penempatan/tujuan TKI di posisi teratas adalah Malaysia dengan persentase 90\% dari data empat tahun terakhir (2012-2015).

Indonesia dan Malaysia dalam pandangan M. R. Islam memiliki hubungan yang dalam dan terikat karena alasan historis, geografis, ekonomi dan kultural. Dalam aspek historis, sejak masa kolonial Inggris menguasai Malaya (sebutan Malaysia dan Singapura di masa kolonial Inggris), penduduk Indonesia sudah melakukan migrasi bahkan sampai menetap. Kegiatan ini menjadi lancar karena jarak geografis yang terbilang dekat. Dalam aspek ekonomi dikarenakan terjadinya interaksi antara masyarakat, maka perniagaan (jual beli) merupakan salah satu upaya yang dilakukan untuk memenuhi kebutuhan hidupnya. Kemudian dalam aspek kultural, Indonesia dan Malaysia memiliki kemiripan yang dikuatkan sebagai simbol bangsa "serumpun melayu". Kesadaran identitas sebagai sesama Melayu seharusnya saling mengisi dalam migrasi pekerja karena keduanya berpotensi besar mengembangkan hubungan yang saling menguntungkan (mutual benefits) baik dalam 
bidang ekonomi maupun politik, khususnya dalam sektor ketenagakerjaan. $^{4}$

Kedutaan Besar Republik Indonesia (KBRI) di Kuala Lumpur, Malaysia menyebutkan bahwa per-Oktober 2013 jumlah WNI yang terdata oleh perwakilan Indonesia di Malaysia sebanyak 2.591.447 jiwa dimana sebanyak 1.306.756 jiwa berstatus pekerja migran Indonesia (PMI) atau sebesar 50,42\% yang bekerja di berbagai sektor. Dari jumlah PMI tersebut, 550.422 jiwa bekerja di sektor perkebunan, disusul penata laksana rumah tangga (PLRT) sebanyak 240.130 jiwa, industri manufaktur sebanyak 177.684 jiwa, konstruksi 177.573 jiwa, servis/jasa (59.036 jiwa), pertanian (53.852 jiwa), bidang agrikultur lainnya (47.661 jiwa), peternakan/perikanan (265 jiwa) dan industri perminyakan (133 jiwa). ${ }^{5}$

Pekerja migran asal Sulawesi Selatan menurut data yang diperoleh dari BP3TKI Makassar menyebutkan bahwa pekerja ini dikontrak oleh perusahaan dan berstatus pekerja sektor formal, sebagian besar dipekerjakan oleh perusahaan perkebunan. Sedangkan pekerja asal Sulawesi Selatan tidak berminat menjadi Penata Laksana Rumah Tangga (PLRT) yang masuk dalam kategori pekerja sektor informal. Di samping itu, pemerintah provinsi Sulawesi Selatan juga mencanangkan program penempatan TKI di sektor formal yang menjadi bagian dari program kerja Gubernur Syahrul Yasin Limpo. Walaupun pemerintah daerah tidak

\footnotetext{
${ }^{4}$ M.R. Islam, Partnership Research Between Malaysia and Indonesia : A Case of Labor Welfare, Social Research Reports, Vol. 25, 2013, hh.7-8.

${ }^{5}$ Kedutaan Besar Republik Indonesia Kuala Lumpur. 2013. Data Tenaga Kerja Indonesia Tahun 2013. Kuala Lumpur: KBRI Kuala Lumpur.
} 
memiliki regulasi khusus yang mengatur penempatan TKI, hanya terbatas pada konsultasi dan koordinasi. ${ }^{6}$

Sektor perkebunan yang menjadi lapangan kerja pekerja migran asal Sulawesi Selatan perlu mendapatkan perhatian yang serius dari para pihak, dikarenakan minat pada sektor ini yang tinggi. Menurut Asrial Chaniago dari Asosiasi Pengusaha Indonesia (Apindo) dikutip dari Detik Finance menyatakan bahwa pekerja sektor perkebunan di Malaysia seperti di Sabah dan Serawak rata-rata mendapatkan gaji sekitar 800 ringgit atau setara dengan Rp 2,9 juta per bulan. Tetapi justru profesi pekerja di sektor perkebunan sama sekali tidak dilirik oleh masyarakat Malaysia. Bagi mereka, menjadi pekerja perkebunan tidak akan mencukupi kebutuhan hidupnya setiap bulan. Masyarakat Malaysia lebih memilih mencari pekerjaan di pusat kota Malaysia seperti Penang dan Johor, karena upah yang jauh lebih besar yakni minimal 900 ringgit atau sekitar Rp. 3,2 juta/bulan bergantung negosiasi gaji antara pekerja dan pengusaha. $^{7}$

Animo pekerja migran asal Sulawesi Selatan ke Malaysia semakin tinggi. Harian Amanah merilis berita sebanyak 74 Tenaga Kerja Indonesia (TKI) asal Sulawesi Selatan diberangkatkan ke Malaysia melalui Pelaksana Penempatan TKI Swasta (PPTKIS) PT Persada Duta Utama Kota Parepare. Sebelum diberangkatkan TKI tersebut dilepas oleh Walikota Pare-Pare. General Manager (GM) PT Persada Duta Utama

\footnotetext{
${ }^{6}$ Hasil Wawancara Pra-Penelitian di BP3TKI Makassar pada 29 Desember 2015.

${ }^{7}$ Detik Finance. 2014. Pekerja Perkebunan di Malaysia Didominasi TKI, Ini Alasannya http://finance.detik.com/read/2014/11/08/173138/2742842/4/pekerja-perkebunan-dimalaysia-didominasi-tki-ini-alasannya, diakses 2 Maret 2016.
} 
wilayah Indonesia Timur, Sarjimin, mengatakan TKI yang diberangkatkan tersebut sudah melalui seleksi tenaga kerja resmi sesuai prosedur Pemerintah yang berlaku. Salah seorang TKI, Wahdah asal Bulukumba, mengaku tertarik menjadi TKI karena tergiur gaji tinggi di Sarawak, Malaysia. la menyatakan bahwa kata orang di sana gajinya per hari 30 ringgit, dan bekerja di kebun kelapa sawit. la berangkat dengan suami dan anaknya. $^{8}$

Migrasi pekerja Indonesia ke luar negeri bermotif ekonomi terlihat dari pernyataan salah satu TKI asal Sulawesi Selatan. Sehingga tolok ukur dari keberhasilan proses migrasi ini pada pencapaian remitansi (kiriman uang) yang dikirimkan dari negara tujuan ke daerah asal. Tenaga kerja di Malaysia merupakan penyumbang devisa terbesar dibanding negara-negara tujuan TKI lainnya di kawasan Asia Pasifik. Hal ini diperkuat data Bank Indonesia dan BNP2TKI yang dikutip Suara Pembaruan menyebutkan bahwa remitansi yang masuk ke tanah air selama kurun waktu Januari-November 2013 mencapai US\$ 7.395.017.768 atau setara Rp 81.345.195.448.000 (kurs 1 US $\$=$ Rp. 11.000), khususnya PMI di Malaysia menempati posisi tertinggi dengan nilai US\$ 256.199.843 atau setara Rp. 2.818.198.273.000. ${ }^{9}$ Pekerja migran asal Sulawesi Selatan dalam kurun waktu Januari-November 2013 berkontribusi sebanyak US\$ 600.466 atau setara Rp. 6.329.142.616.

\footnotetext{
${ }^{8}$ Harian Amanah. 2016. 74 TKI asal Sulsel "Adu Nasib" ke Sarawak http://amanah.alharamnews.com/post/1232/74-tki-sulsel-adu-nasib-ke-sarawak, diakses 2 Maret 2016.

9 Suara Pembaruan. 2013. Remitansi TKI Tahun 2013 Capai Rp. 81,34 Triliun http://sp.beritasatu.com/ekonomidanbisnis/remitansi-tki-tahun-2013-capai-rp-8134triliun/47110, diakses 22 November 2015.
} 
Jumlah yang signifikan dari 6.420 TKI yang berkontribusi terhadap roda perekonomian di provinsi Sulawesi Selatan. ${ }^{10}$

Data Bank Indonesia mengenai remitansi tahun 2014 yang diterima BNP2TKI pada minggu pertama Februari 2015 menyebutkan remitansi yang dikirim TKI ke Indonesia dengan nilai US\$ 8.345.070.344 atau setara Rp. 105.982.393.368.800 dengan asumsi nilai tukar Rp. 12.700 per 1 US\$. Negara-negara tujuan Asia Pasifik masih menempati porsi terbesar terhadap perolehan remitansi sebesar US\$ 4.602.968.860 atau setara Rp. 58.457.704.522.000. Khususnya PMI di Malaysia tetap menempati posisi tertinggi dengan nilai US\$ 540.742.074 atau setara Rp. 32.267.424.339.800. ${ }^{11}$ Sedangkan pekerja migran asal Sulawesi Selatan berkontribusi sebesar US\$282.032 dari 4.419 orang setara dengan Rp. 3.452.083.270. ${ }^{12} \mathrm{Hal}$ ini juga terhitung sebagai kontribusi warga Sulawesi Selatan untuk menggerakkan roda perekonomian di daerah asal.

Keberadaan pekerja migran Indonesia (PMI) di Malaysia sebagai pahlawan devisa Indonesia yang turut berperan menggerakkan roda perekonomian di dalam negeri belum mendapatkan rasa aman dan nyaman dalam menjalankan profesinya. Masih rawannya kekerasan yang dialami PMI di Malaysia tergambar dari laporan fungsi ketenagakerjaan KBRI Kuala Lumpur 2011 yang merilis data kasus TKI formal/informal berdasarkan pengaduan langsung maupun surat tercatat. Tercatat kasus

\footnotetext{
10 BP3TKI Makassar. 2013. Laporan Penerimaan Remitansi TKI BP3TKI Makassar Tahun 2013. Makassar: BP3TKI Makassar.

${ }^{11}$ BNP2TKI. 2015. BI Mencatat Remitansi TKI Tahun 2014 sebesar Rp. 105,9 Trilyun http://www.bnp2tki.go.id/read/9887/BI-Mencatat-Remitansi-TKI-Tahun-2014-Sebesar-Rp1059-Trilyun, diakses 24 November 2015.

12 BP3TKI Makassar. 2014. Laporan Penerimaan Remitansi TKI BP3TKI Makassar Tahun 2014. Makassar: BP3TKI Makassar.
} 
di sektor formal sebanyak 254 kasus dengan persentase $24,08 \%$ dan kasus di sektor informal sebanyak 801 kasus dengan persentase 75,92\%. Total laporan yang masuk dalam laporan KBRI Kuala Lumpur sebanyak 1055 kasus. $^{13}$

Data di atas menggambarkan bahwa kasus TKI di sektor informal lebih mendominasi dibandingkan TKI di sektor formal. Lebih lanjut data data kasus TKI informal (legal maupun ilegal) di Malaysia tahun 2013 yang dirilis oleh Kedutaan Besar Republik Indonesia Kuala Lumpur per-31 Oktober 2015 menggambarkan bahwa persoalan pemenuhan hak-hak ekonomi seperti gaji tidak dibayar menempati posisi teratas dengan presentase 24\% dengan 292 kasus di proses dan 111 kasus selesai yang berjumlah 403 kasus dari total 1.693 kasus. Selanjutnya diikuti tidak betah kerja sebanyak 421 kasus (25\%), tidak sesuai perjanjian kerja sebanyak 168 kasus (10\%), eksploitasi sebanyak 162 kasus (10\%), dan pemutusan hubungan kerja (PHK) sepihak sebanyak 59 kasus (3\%). Selebihnya merupakan kategori non-labour cases.

BP3TKI Makassar mencatat permasalahan TKI ke luar negeri periode 2012-2015, khususnya penempatan di Malaysia. Pada tahun 2012 sebanyak 33 kasus, tahun 2013 sebanyak 18 kasus, tahun 2014 sebanyak 29 kasus dan tahun 2015 sebanyak 15 kasus. Permasalahan/kasus yang dihadapi pekerja migran asal Sulawesi Selatan antara lain: klaim asuransi, pemulangan jenazah, pemulangan TKI-B

\footnotetext{
${ }^{13}$ Kedutaan Besar Republik Indonesia (KBRI) Kuala Lumpur. 2011. Laporan Tahunan Fungsi Ketenagakerjaan Tahun 2011. Kuala Lumpur, h.9.
} 
(masa tinggal kadaluwarsa/overstay), pencarian ahli waris dan permohonan pemulangan TKI. ${ }^{14}$

Salah satu permasalahan yang dihadapi oleh pekerja migran asal Sulawesi Selatan adalah masa tinggal kadaluwarsa/overstay. Hal ini juga menjadi perhatian serius dari Kementerian Luar Negeri RI. Tabloid Diplomasi dalam artikel yang ditulis Lalu M. Iqbal, Direktur Perlindungan WNI dan BHI menceritakan kunjungan Menteri Luar Negeri ke salah satu perkebunan kelapa sawit terluas di Malaysia yang terletak di Selangor dan mempekerjakan sekitar 800 pekerja migran Indonesia. ${ }^{15}$

Dalam kesempatan tersebut, Menlu Retno melakukan pertemuan langsung dengan pekerja dan manajemen pengelola perkebunan. Salah satu yang keluhan yang disampaikan oleh para pekerja adalah terkait dengan izin tinggal yang prosesnya sangat lama yaitu sekitar tiga hingga enam bulan, sehingga dalam jeda waktu tersebut para pekerja migran tersebut tidak bisa bepergian kemana-mana. Padahal mereka juga memiliki keperluan untuk keluar dari perkebunan, misalnya keperluan untuk mentransfer uang dan membeli kebutuhan sehari-hari. Hal inilah yang menyebabkan banyaknya para pekerja yang ditangkap, padahal mereka sudah mengajukan izin tinggal namun belum disahkan. Terkait hal ini Menlu Retno meminta perhatian serius manajemen perkebunan dan

\footnotetext{
${ }^{14}$ BP3TKI Makassar. 2015. Data Permasalahan TKI ke Luar Negeri BP3TKI Makassar, 2012, 2013, 2014 dan 2015. Makassar: BP3TKI Makassar.

15 Lalu M. Iqbal, "Kontribusi PMI terhadap Kemajuan Malaysia: Perlu Diimbangi dengan Perlindungan dan Kesejahteraan" Tabloid Diplomasi No. 85 Tahun VIII 15 Februari-14 Maret 2015, h. 8.
} 
berjanji untuk membahasnya secara bilateral dengan pemerintah Malaysia dan akan meminta perhatian secara khusus. ${ }^{16}$

Pusat Sumber Daya Buruh Migran merilis berita tentang kondisi pekerja perkebunan sawit di Indonesia dan Malaysia yang semakin mengkhawatirkan dalam dua puluh tahun terakhir. Di kedua negara ini, populasi pekerja yang tidak terdokumentasi semakin tinggi. Di Indonesia, hanya 30 persen buruh yang tercatat sebagai buruh tetap, sementara 70 persen tidak tercatat sebagai buruh. Mereka biasa disebut sebagai buruh kontrak, kernet, dan buruh harian lepas. Sementara di Malaysia, buruh tidak berdokumen semakin meningkat setelah lahirnya kebijakan kontrak pendek pekerja di perkebunan sawit bagi pekerja migran. Sejak tahun 1990, Malaysia menerapkan peraturan baru tentang kontrak pekerja migran yang maksimal 3 tahun, dan hanya bisa diperpanjang dua kali masing-masing sebanyak satu tahun, yang disebut dengan skema 311. Dampaknya adalah buruh yang tetap bekerja memilih lari ke hutan ketika polisi Diraja Malaysia melakukan penertiban. ${ }^{17}$

Saurli Siagian, peneliti sosial dikutip Pusat Sumber Daya Buruh Migran menyatakan bahwa hak-hak dasar pekerja yang tidak terdokumentasi tidak bisa dipenuhi baik oleh pemerintah maupun perusahaan. Hal itu seperti hak atas upah layak, kesehatan, pendidikan, asuransi, hak pensiun, hak berorganisasi tidak diterima oleh sekitar tujuh juta pekerja perkebunan di Indonesia. Murni Sima dari Serikat Buruh

\footnotetext{
${ }^{16}$ Ibid.

${ }^{17}$ Pusat Sumber Daya Buruh Migran. 2015. Pekerja Perkebunan Sawit Indonesia dan Malaysia Makin Termarjinalkan http://buruhmigran.or.id/2015/03/24/pekerjaperkebunansawitindonesiadanmalaysiamakint ermarjinalkan/, diakses 2 Maret 2016.
} 
Perkebunan di Sabah (SPIEU) menyampaikan bahwa hanya di Sabah Malaysia saja, terdapat 112.000 orang pekerja Indonesia yang berdokumen lengkap, sekitar 200.000 orang bekerja tanpa dokumen yang sah dan lengkap. Buruh tanpa dokumen ini menjadi lahan kriminalisasi polisi. Seperti menjadi objek kekerasan, pemerasan, intimidasi dan selalu mengganggu ketertiban dan penyebab permasalahan. Anwar Maaruf dari Migran Center, mengungkapkan bahwa sumber-sumber buruh migran ke perkebunan perkebunan sawit berasal dari kantong-kantong desa miskin yang tersebar di berbagai Provinsi seperti pedesaan-pedesaan di Nusa Tenggara Timur, Sulawesi Selatan, Lombok, dan Sumatera Utara. ${ }^{18}$

Besarnya jumlah pekerja migran Indonesia yang melakukan migrasi kerja ke Malaysia seharusnya menjadi pertimbangan pemerintah dalam mengembangkan kebijakan yang efektif untuk menyediakan mekanisme penempatan yang sesuai dengan standar HAM. Di samping itu, pemerintah pusat dan daerah asal TKI/PMI perlu bersinergi untuk memastikan hak-hak pekerja migran Indonesia terlindungi dengan melakukan penyiapan yang baik pada masa pra-penempatan dan melakukan pengawasan pada masa penempatan. Pemerintah pusat yang diwakili BNP2TKI untuk mengawal proses penempatan dan perlindungan TKI seringkali menjadi pihak yang disalahkan apabila TKI di luar negeri mendapat masalah. Namun demikian, proses yang juga perlu dilihat yakni bagaimana pemerintah daerah yang merupakan asal daerah TKI

\footnotetext{
${ }^{18}$ Ibid.
} 
mengawal proses penyiapan TKI melalui Balai Pelayanan Penempatan dan Perlindungan TKI (BP3TKI) di daerahnya masing-masing.

Pihak-pihak yang berinteraksi dan menjadi aktor ekonomi politik dalam proses migrasi pekerja ini antara lain: pemerintah sebagai pihak yang memastikan bahwa proses penempatan telah berjalan sesuai prosedur sehingga TKI/PMI bisa diberikan perlindungan optimal di negara tujuan, perusahaan (Pelaksana Penempatan Tenaga Kerja Indonesia Swasta/PPTKIS) sebagai pihak yang merekrut telah memastikan bahwa TKI/PMI yang akan ditempatkan telah memenuhi standar dan kualifikasi yang dicantumkan dalam permintaan tenaga kerja (job order), dan TKI sebagai pihak yang akan/telah bekerja di luar negeri memiliki keterampilan yang sesuai dengan pekerjaannya. Interaksi di antara aktor ini dalam pemenuhan hak-hak pekerja migran asal Sulawesi Selatan akan dianalisis lebih lanjut dalam penelitian yang berjudul: Analisis Ekonomi Politik Pemenuhan Hak-Hak Pekerja Migran Asal Sulawesi Selatan di Malaysia.

\subsection{Rumusan Masalah}

Berdasarkan uraian latar belakang masalah di atas, maka rumusan masalah penelitian sebagai berikut:

1. Bagaimana pemenuhan hak-hak pekerja migran asal Sulawesi Selatan di Malaysia berdasarkan UU No. 39 Tahun 2004 pada masa prapenempatan?

2. Bagaimana pemenuhan hak-hak pekerja migran asal Sulawesi Selatan di Malaysia berdasarkan UU No. 39 Tahun 2004 pada masa penempatan? 


\subsection{Tujuan dan Manfaat Penelitian}

\section{Tujuan Penelitian}

Melalui penulisan tesis ini beberapa tujuan yang ingin dicapai oleh penulis, sebagai berikut:

1. Menggambarkan dan menganalisis pemenuhan hak-hak pekerja migran asal Sulawesi Selatan di Malaysia berdasarkan UU No. 39 Tahun 2004 pada masa pra-penempatan.

2. Menggambarkan dan menganalisis pemenuhan hak-hak pekerja migran asal Sulawesi Selatan di Malaysia berdasarkan UU No. 39 Tahun 2004 pada masa penempatan.

\section{Manfaat Penelitian}

Manfaat Akademik

a. Menunjukkan secara ilmiah analisis ekonomi politik pemenuhan hakhak pekerja migran asal Sulawesi Selatan di Malaysia yang merupakan implementasi kebijakan pemerintah pusat kepada pemerintah daerah.

b. Memperkaya kajian ekonomi politik untuk pengembangan keilmuan, khususnya bidang migrasi pekerja internasional.

Manfaat Praktis

a. Memberikan bahan rujukan kepada stakeholder untuk mengambil kebijakan yang efektif dalam pemenuhan hak-hak pekerja migran asal Sulawesi Selatan di Malaysia.

b. Memberikan pemahaman kepada masyarakat mengenai hak dan kewajiban pemerintah terhadap pekerja migran asal Sulawesi Selatan dan sebaliknya. 


\section{BAB II}

\section{TINJAUAN PUSTAKA}

Bab ini membahas enam bagian antara lain: Perspektif Ekonomi Politik, Ekonomi Politik Kelembagaan, Ekonomi Politik Sektoral, Hak-Hak Pekerja Migran Indonesia, Hasil Penelitian yang Relevan dan Kerangka Pemikiran.

\subsection{Perspektif Ekonomi Politik}

Proses formulasi teori ekonomi politik dalam lintasan sejarah sudah sangat lama. Clark (1998:21-23) dari perspektif ini menyatakan bahwa teori ekonomi muncul dan dapat dilacak dari periode antara abat 14 dan 16, yang biasa disebut masa 'transformasi besar' (great transformation) di Eropa Barat sebagai implikasi dari sistem perdagangan yang secara perlahan menyisihkan sistem ekonomi feudal pada abad pertengahan. Tumbuhnya pasar ekonomi baru yang besar tersebut telah memunculkan peluang ekspresi bagi aspirasi-aspirasi individu dan memperkuat jiwa kewirausahaan yang sebelumnya ditekan oleh lembaga keagamaan, negara dan komunitas. ${ }^{1}$

Selanjutnya, pada abad 18 mulai masuk abad pencerahan (enlightenment) yang marak di Perancis dengan para pelopornya, antara lain: Voltaire, Diderot, D’Alembert dan Condilac. Pusata gagasan dari perumus ide pencerahan itu adalah adanya otonomi individu dan eksplanasi kapasitas manusia (human capacity). Para pemimpin dari aliran ini mempercayai bahwa kekuatan akal akan dapat menyingkirkan

\footnotetext{
${ }^{1}$ Ahmad Erani Yustika, (2009), Ekonomi Politik: Kajian Teoretis dan Analisis Empiris, Yogyakarta: Pustaka Pelajar, h. 2.
} 
manusia dari segala bentuk kesalahan (mistake). Ide dari abad Pencerahan inilah, yang bertumpu kepada ilmu pengetahuan masyarakat (science of society), yang sebetulnya menjadi dasar teori ekonomi politik. Sedangkan istilah ekonomi politik (political economy) pertama kali diperkenalkan oleh Antoyne de Montchètien (1575-1621) dari Perancis, dalam bukunya yang bertajuk Tretise on Political Economy. Sedangkan dalam bahasa Inggris penggunaan istilah ekonomi politik terjadi pada 1767 lewat publikasi Sir James Steuart (1712-1789) berjudul Inequiry into the Principles of Political Economy. ${ }^{2}$

Ahli ekonomi politik di awal masa-masa itu mengembangkan ide tentang keperluan negara untuk menstimulasi kegiatan ekonomi (bisnis). Pasar dianggap masih belum berkembang pada saat itu, sehingga pemerintah memiliki tanggung jawab untuk membuka wilayah baru perdagangan, memberikan perlindungan (pelaku ekonomi) dari kompetisi dan menyediakan pengawasan untuk produk yang bermutu. Namun akhir abad 18, pandangan itu ditentang karena dianggap pemerintah (negara) bukan lagi sebagai agen yang baik untuk mengatur kegiatan ekonomi (beneficient director of economic activity), tetapi justru sebagai badan yang merintangi upaya untuk memperoleh kesejahteraan (Clark, 1998:23).

Perdebatan antara para ahli ekonomi politik itulah yang akhirnya memunculkan banyak sekali aliran dalam tradisi pemikiran ekonomi politik. Secara garis besar, mazhab itu dapat dibagi dalam tiga kategori, yakni: (1) aliran ekonomi politik konservatif yang diprakarsai oleh Edmund Burke; (2)

2 Ibid. h. 3. 
aliran ekonomi politik klasik yang dipelopori oleh Adam Smith, Thomas Malthus, David Ricardo, Nassau Senior dan Jean Baptiste Say; dan (3) aliran ekonomi politik radikal yang dipropagandakan oleh William Godwin, Thomas Paine, Marquis de Condorcet dan Karl Marx. ${ }^{3}$ Detil aliran-aliran ekonomi politik dapat dilihat pada Bagan 2.1.

Bagan 2.1 Sejarah dan Cabang Ilmu Ekonomi Politik

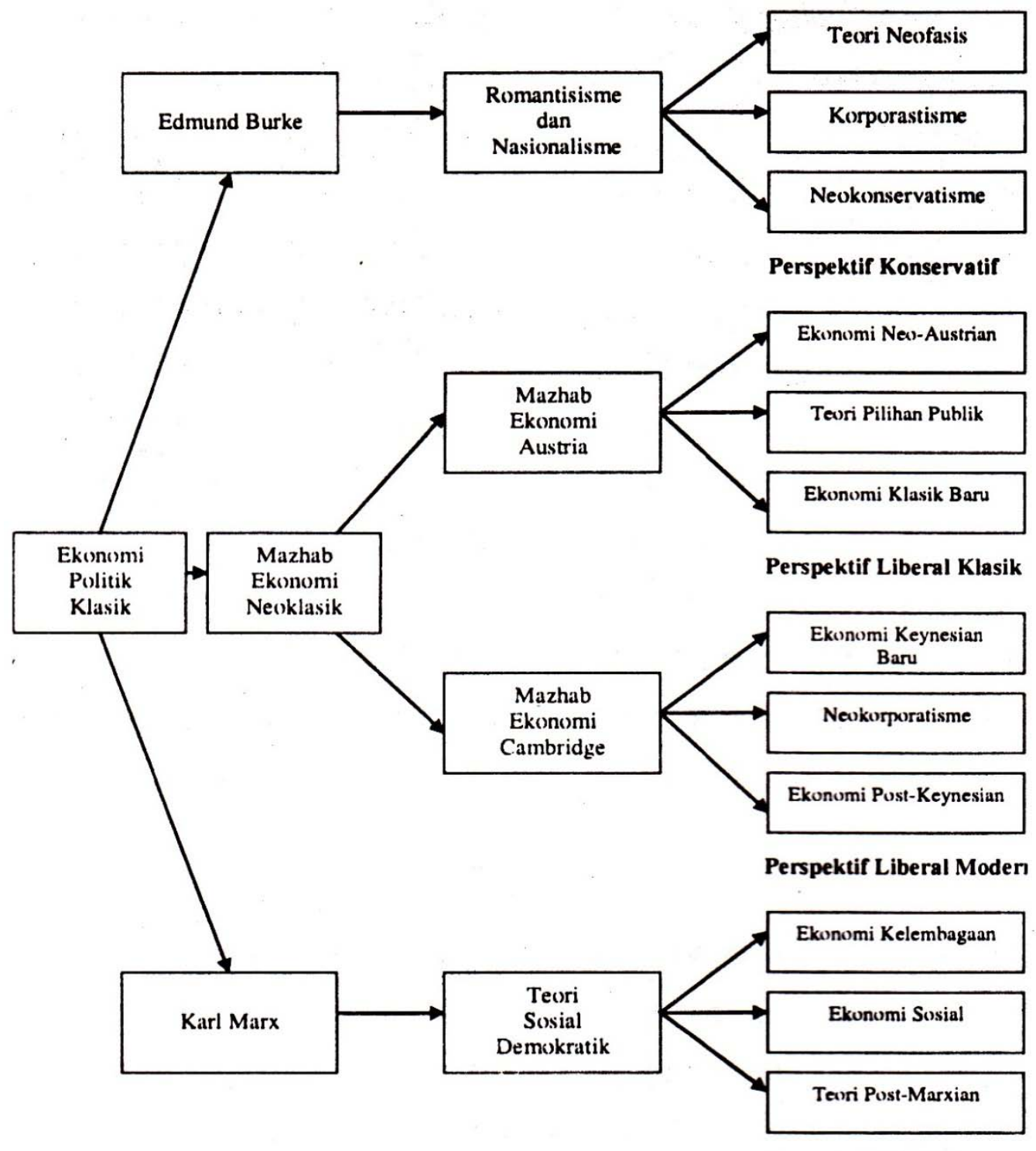

Perspektif Radikal

Sumber: Clark (1998:24) dalam Ahmad Erani Yustika (2009:4)

\footnotetext{
3 Ibid. hh. 3-4.
} 
Ekonomi politik secara definitif dimaknai sebagai interrelasi di antara aspek, proses, dan institusi politik dengan kegiatan ekonomi (produksi, investasi, penciptaan harga, perdagangan, konsumsi dan lain sebagainya) [Caporaso dan Levine, 1992:31]. Mengacu pada definisi tersebut, pendekatan ekonomi politik mengaitkan seluruh penyelenggaraan politik, baik yang menyangkut aspek, proses maupun kelembagaan dengan kegiatan ekonomi yang dilakukan oleh masyarakat maupun yang ditawarkan oleh pemerintah. Harus juga dipahami bahwa pendekatan ini meletakkan bidang politik subordinat terhadap ekonomi. Artinya, instrumen-instrumen ekonomi seperti mekanisme pasar (market mechanism), harga dan investasi dianalisis dengan mempergunakan pengaturan sistem politik, di mana kebijakan atau peristiwa ekonomi tersebut terjadi. Dengan kata lain, pendekatan ini melihat ekonomi sebagai cara untuk melakukan tindakan (a way of acting), sedangkan politik menyediakan ruang bagi tindakan tersebut (a place to act). Pengertian ini sekaligus meluruskan bahwa pendekatan ekonomi politik tidak dapat dicampur karena keduanya memiliki dasar yang berbeda. ${ }^{4}$

Ilmu ekonomi (economics) dan ilmu politik (politics) memang berlainan, dalam pengertian di antara keduanya mempunyai alat analisis sendiri-sendiri yang memiliki asumsi yang berlawanan (Caporaso dan Levine, 1992:7). Ekonomi dan politik bisa disejajarkan dengan pertimbangan keduanya mempunyai proses yang sama. Keduanya memiliki perhatian yang sama terhadap isu-isu sebagai berikut:

\footnotetext{
${ }^{4}$ Ibid. h.8.
} 
mengorganisasi dan mengkoordinasi kegiatan manusia, mengelola konflik, mengalokasikan beban dan keuntungan dan menyediakan kepuasan bagi kebutuhan dan keinginan manusia (Clark, 1998:6). Berdasarkan pemahaman ini, ekonomi politik mempertemukan antara bidang ekonomi dan politik dalam hal alokasi sumber daya ekonomi dan politik (yang terbatas) untuk dapat memenuhi kebutuhan masyarakat. Oleh karena itu, implementasi dari kebijakan ekonomi politik selalu mempertimbangkan struktur kekuasaan dan sosial yang hidup dalam masyarakat, khususnya target masyarakat yang menjadi sasaran kebijakan. ${ }^{5}$

Ilmu ekonomi secara definitif selalu merujuk pada tiga konsep berikut: (1) kalkulasi (calculation); (2) penyediaan materi (material provisioning) dan (3) meregulasi sendiri (self regulating) [Caporaso dan Levine, 1992:21-30]. Konsep tersebut dapat dijabarkan sebagai berikut. Ujung dari analisis ekonomi selalu berupaya untuk mencari kalkulasi hasil yang paling efisien di antara keterbatasan pilihan yang tersedia (constrained choice). Semakin efisien hasil yang diperoleh, maka semakin bagus pilihan yang diambil. Selain itu, kegiatan ekonomi selalu bertujuan untuk melakukan produksi (reproduksi) dan sirkulasi (distribusi). Dalam konteks ini, penyediaan material (barang/jasa) dalam kegiatan ekonomi selalu bersinggungan dengan desain struktur produksi. Terakhir, ekonomi berargumentasi bahwa pasar bisa mengatur dirinya sendiri. Pada titik inilah antara ekonomi dan politik (kelembagaan) itu terpisah. Kurang lebih analisis ekonomi bekerja dengan menggunakan tiga koridor tersebut. ${ }^{6}$

\footnotetext{
5 Ibid. hh. 8-9.

${ }^{6}$ Ibid. hh. 9-10.
} 
IImu politik juga berjalan dengan tiga konsep baku, yakni politik sebagai pemerintah (government), otoritas yang mengalokasikan nilai (authoritative allocation of values), dan publik (public) [Caporaso dan Levine, 1992:7-15]. Politik sebagai pemerintah jelas tugasnya untuk memberikan arahan dan mengeluarkan regulasi. Sifat pemerintah berupaya menyediakan panduan dan melakukan intervensi sehingga bertabrakan dengan sifat ekonomi yang mempercayai pasar bisa bekerja secara mandiri. Selanjutnya, politik juga mengalokasikan nilai-nilai. Konsep nilai dalam politik tidak setumpul nilai dalam ekonomi yang sering dimaknai sekedar efisiensi/laba. Dalam politik, nilai itu bekerja berdasarkan norma-norma yang hidup di masyarakat, seperti perlunya pemerataan/keadilan pembangunan. Kemudian politik sebagai publik bermakna bahwa luaran dari politik selalu merupakan urusan bersama (public concern), berbeda dengan ekonomi yang berkonotasi privat. ${ }^{7}$

Menurut Staniland (1985) pembauran antara ilmu ekonomi dan ilmu politik bisa menghasilkan satu dari dua metode analisis berikut: (1) metode analisis politik ekonomi (the political theory of economics) yaitu penerapan cara pendekatan yang berasal dari teori politik untuk memahami permasalahan-permasalahan ekonomi, dan (2) metode analisis ekonomi politik (the economics theory of politics) yaitu penerapan cara pendekatan yang bersumber dari teori ekonomi untuk memahami permasalahan-permasalahan politik. ${ }^{8}$

\footnotetext{
${ }^{7}$ Ibid. h. 10.

${ }^{8}$ Deliarnov. (2006). Ekonomi Politik. Jakarta: Penerbit Erlangga, h. 15.
} 
Metode analisis politik-ekonomi menggunakan teori politik untuk memahami berbagai permasalahan ekonomi, sebab jika didasarkan pada teori ekonomi saja, maka tidak mampu menerangkan secara memuaskan bagaimana suatu peristiwa ekonomi terjadi; bagaimana suatu proses ekonomi muncul; atau bagaimana perilaku aktor ekonomi dalam menghadapi proses atau peristiwa ekonomi tertentu. Berbeda dengan pakar ekonomi murni, pakar politik ekonomi, tidak akan berhenti pada analisis dari sekumpulan variabel atau parameter ekonomi pada saat mencoba memahami suatu peristiwa ekonomi, tetapi juga akan menyelidiki siapa saja aktor yang terlibat yang menyebabkan adanya perubahan dalam variabel atau parameter tersebut. Selain itu, mereka juga berusaha meneliti struktur sosial dan politik yang menghubungkan satu aktor dengan yang lainnya. ${ }^{9}$

Pakar ekonomi politik berusaha menjelaskan tindakan-tindakan ekonomi yang dilakukan oleh aktor-aktor tertentu pada saat mereka melakukan aktivitas politik. Menurut pakar ekonomi politik, di belakang kegiatan politik aktor tertentu ada motivasi ekonomi yang mendasarinya. Berdasarkan kajian ekonomi politik inilah muncul analisis perilaku kalaprente yang banyak dijumpai di negara-negara berkembang. Dengan menggunakan metode analisis kalap-rente ini dapat dipahami mengapa teori politik saja tidak dapat digunakan untuk memahami berbagai peristiwa politik di negara-negara sedang berkembang.

\footnotetext{
${ }^{9}$ Ibid. hh. 15-16.
} 
Caporaso dan Levine (1993) mengelompokkan model-model ekonomi politik sesuai "substansi" dan "metodologi" yang digunakan dalam analisis. Selengkapnya digambarkan pada tabel 2.1.

Tabel 2.1 Model-Model Ekonomi Politik dari Metodologi dan Substansi

\begin{tabular}{|l|l|l|}
\hline \multirow{2}{*}{ Metodologi } & \multicolumn{2}{|c|}{ Substansi } \\
\cline { 2 - 3 } & \multicolumn{1}{|c|}{ Ekonomi } & \multicolumn{1}{c|}{ Politik } \\
\hline \multirow{2}{*}{ Ekonomi } & $\begin{array}{l}\text { Sel 1: Pengaplikasian } \\
\text { Metodologi Ekonomi } \\
\text { dalam Substansi } \\
\text { Ekonomi (Ekonomi } \\
\text { Murni) }\end{array}$ & $\begin{array}{l}\text { Sel 2: Pengaplikasian } \\
\text { Metodologi Ekonomi } \\
\text { dalam Substansi Politik }\end{array}$ \\
\hline Politik & $\begin{array}{l}\text { Sel 3: Pengaplikasian } \\
\text { Metodologi Politik } \\
\text { dalam Substansi } \\
\text { Ekonomi }\end{array}$ & $\begin{array}{l}\text { Sel 4: Pengaplikasian } \\
\text { Metodologi Politik } \\
\text { dalam Substansi Politik } \\
\text { (Politik Murni) }\end{array}$ \\
\hline
\end{tabular}

Sumber: Caporaso dan Levine (1993) dalam Deliarnov (2006:16)

Metodologi ekonomi dalam substansi ekonomi (Sel 1) digolongkan dalam bidang ekonomi tradisional atau ekonomi murni yang biasa dipelajari oleh mahasiswa Fakultas Ekonomi. Hal-hal yang dipelajari biasanya terkait dengan perilaku agen-agen ekonomi dalam mengoptimalkan kesejahteraan masing-masing dalam pengaturan pada pasar, teori harga atau efisiensi dalam konsumsi, produksi dan alokasi. Begitu juga untuk substansi politik yang dibahas dengan metodologi yang dibahas dengan menggunakan metodologi politik (Sel 4) merupakan kajian bidang politik murni yang dipelajari mahasiswa pada Fakultas IImu Sosial dan Ilmu Politik. Hal yang dipelajari biasanya terkait dengan kekuasaan dalam arena politik. ${ }^{10}$

${ }^{10}$ Ibid. h. 16. 
Kedua kasus (Sel 2 dan Sel 3) menarik untuk dikaji. Jika substansi politik dikaji dengan metodologi ekonomi (Sel 2) yang dikaji adalah pengaplikasian metode-metode ekonomi dalam hal-hal yang menyangkut politik. Sedangkan, jika substansi ekonomi dikaji dengan metodologi politik (Sel 3) yang dipelajari dan dibahas adalah pengaplikasian metode-metode politik dalam aktivitas-aktivitas ekonomi. Penerapan metodologi ekonomi ke dalam keputusan-keputusan politik telah dikembangkan oleh pakarpakar sosial, seperti yang dilakukan oleh pakar ekonomi politik kelembagaan. Sedangkan aplikasi metodologi politik dalam aktivitasaktivitas ekonomi relatif agak sulit. ${ }^{11}$

Berdasarkan penjelasan pada bagian ini maka dapat dipahami bahwa perspektif ekonomi politik yang digunakan dalam penelitian ini tidak hanya menyatakan hubungan ilmu ekonomi dan ilmu politik yang bermakna eksplanatori (menjelaskan bagaimana keduanya terkait) maupun normatif (bagaimana seharusnya sifat perkaitan di antara kedua disiplin ilmu tersebut). Penggunaan ekonomi politik ini juga tidak hanya digunakan sebagai pembungkus topik bahasan untuk membuat penelitian ini lebih keren sehingga orang tertarik membacanya, sebagaimana disinggung oleh Staniland. Pemaparan dalam perspektif ekonomi politik di atas menjadi landasan bagi peneliti untuk mengembangkan analisis ekonomi politik pemenuhan hak-hak pekerja migran asal sulawesi selatan di Malaysia.

${ }^{11}$ Ibid. 


\subsection{Ekonomi Politik Kelembagaan}

Ekonomi politik kelembagaan merupakan salah satu cabang ilmu ekonomi politik yang digunakan untuk memecahkan masalah-masalah ekonomi maupun politik. Pandangan ini didasarkan pada kenyataan bahwa sebagian besar persoalan ekonomi maupun politik justru berada di luar wilayah ekonomi dan politik itu sendiri, yaitu dalam kelembagaan yang mengatur proses kerja suatu perekonomian maupun proses-proses politik. Studi tentang kelembagaan menempati posisi penting dalam ilmu ekonomi politik karena fungsinya sebagai mesin sosial sangat mendasar. Konteks ekonomi politik, institusi merupakan tulang punggung dari sistem ekonomi politik. Kelemahan dan kekuatan ekonomi dan politik suatu masyarakat dapat dilihat langsung dari kelemahan institutsi ekonomi dan politik yang mendasarinya. Oleh karena itu, kita perlu mengembangkan ekonomi politik kelembagaan, sebab baik buruknya sistem ekonomi dan politik sangat tergantung pada kelembagaan yang membingkainya. ${ }^{12}$

Analisis institusional minimal memiliki akar yang sangat kuat dari tiga disiplin ilmu sosial, yaitu ekonomi, sosiologi dan politik. Analisis institusional muncul pada akhir abad ke-19. Periode ini sangat penting sebab saat itu banyak sekali sistem-sistem kelembagaan berubah terutama dengan terciptanya konstitusi-konstitusi demokratis yang lebih formal. Saat itu hampir semua negara di Eropa mulai menjadikan hukum sebagai instrumen tidak hanya untuk pemegang kekuasaan, tetapi juga

12 Ibid. h. 95. 
bagi warga negara sebagai alat untuk melindungi diri mereka dari kekuasaan negara. (Bogason, 2000) $)^{13}$

Thorstein Veblen menyatakan kelembagaan sebagai norma-norma yang membentuk perilaku masyarakat dalam bertindak, baik dalam perilaku konsumsi maupun produksi. Hal ini sesuai dengan definisi yang dikemukakan Veblen (1926) tentang kelembagaan, yaitu sebagai: “... settled habits of thought common to the generality of men". Selanjutnya, Max Weber, Joseph Schumpeter dan Gunnar Myrdal mengembangkan pendekatan kelembagaan dari perspektif sosiologi. Ketiga tokoh ini lebih tertarik membahas peran wirausahawan dalam industrialisasi dan pembangunan. Topik tentang peran wirausahawan ini tidak dibahas sama sekali dalam perspektif ekonomi politik Liberalisme klasik maupun neoklasik. Sedangkan, John R. Commons, Ronald Coase, Douglas North, dan Williamson lebih terfokus pada peran hukum (dan kebijakan) dalam sistem ekonomi politik. Bagi Commons, kelembagaan adalah "collective action in restraint, liberation and expansion of individual action", sedangkan bagi North (1994) kelembagaan diartikan sebagai "humanly devised constrains that shape human interaction". ${ }^{14}$

Penelitian ini dapat dianalisis lebih mendalam dengan menggunakan pendekatan peran hukum dalam ekonomi politik kelembagaan yang dikemukakan oleh Commons, Coase dan North. Hal ini sejalan dengan pendapat pakar-pakar kelembagaan yang menyatakan bahwa ekonomi pasar tidak tercipta dengan sendirinya. Ekonomi pasar

${ }^{13}$ Ibid. 
perlu memenuhi prasyarat tegaknya suatu institusi yang dapat mengatur pola interaksi beberapa aktor dalam suatu arena transaksi yang disepakati bersama. Kelembagaan dilihat dari sisi hukum menentukan dan/atau mewarnai transaksi, terutama melalui aturan main yang berlaku, sekaligus juga mengatur kelompok atau agen ekonomi untuk mewujudkan kontrol kolektif terhadap transaksi. Tanpa kehadiran institusi, biaya transaksi menjadi tinggi. Selain itu, pelaku ekonomi akan menghadapi resiko penipuan, pemerasan, ancaman fisik dan bentuk-bentuk ketidaksiapan lainnya. ${ }^{15}$

Commons merupakan orang pertama yang memperkanlkan istilah "working rules" yang mengaitkan kelembagaan dengan aspek legalistik dalam perspektif ekonomi politik kelembagaan. Commons (1961) menjelaskan tentang aspek legalistik sebagai berikut: "Individuals must or must not do (duty) what they may do without interference from other individuals (privilege), what they can do with the aid of the collective power (right) and what they cannot expect the collective power to do in their behalf (no right)". Pernyataan tersebut dapat diartikan: Individu harus atau tidak harus melakukan (tugas) apa yang mungkin mereka lakukan tanpa campur tangan dari orang lain (hak istimewa), apa yang bisa mereka lakukan dengan bantuan kekuatan bersama (benar) dan apa yang mereka tidak bisa mengharapkan kekuatan bersama yang dapat dilakukan atas nama mereka (tidak benar).

${ }^{15}$ Ibid. h. 99. 
Ronald Coase juga cukup intens membahas peran hukum, terutama terkait dengan hak-hak kepemilikan. Menurut Coase dalam The Problem of Social Cost (1960), "with positive transaction costs, resource allocations are altered by the structure of property rights". Arti pernyataan tersebut: dengan biaya transaksi yang positif, alokasi sumber daya dapat diubah oleh struktur hak-hak kepemilikan. Pandangan ini didukung oleh Harold Demsetz dan Richard Posner. Sebagai catatan, pemikiran Desetz dan Posner tentang superioritas hak-hak kepemilikan swasta konsisten dengan pemikiran ekonom aliran utama. ${ }^{16}$ (Bromley, 1989)

Douglas North dan Robert Fogel semakin mempopulerkan pendekatan kelembagaan. North seperti pakar-pakar ekonomi politik kelembagaan yang lain juga menolak anggapan klasik bahwa pasar adalah satu-satunya penggerak roda ekonomi, sebab peran institusi (ekonomi maupun politik) tidak kalah penting dalam pembangunan. North dan Thomas (1973) mendefinisikan institusi sebagai: "an arrangement between economic units defines and specifies the way by which these units can co-operate or compete". Artinya, institusi berperan dalam mengatur bagaimana unit-unit ekonomi melakukan kerjasama atau berkompetisi satu sama lainnya. ${ }^{17}$

Dalam Institutional and a Transaction Cost Theory of Exchange (1994), North dengan tegas menyatakan: "institutions are the humanly devised constraints that shape human interaction". Selain itu, North dalam artikel "Transaction Costs, Institutions and Economic History" (1984)

${ }^{16}$ Ibid.

17 Ibid. 
menjelaskan bahwa: "institutions consists of a set of constraints or behavior in the form of rules and regulations; a set of procedures to detect deviations from the rules and regulations; and finally a set of moral, ethical behavioral norms which define the countours that constrain the way in which the rules and regulations are specified and enforcement is carried out... institutions are rules of procedures that prescribe, proscribe or permit particular behavior". ${ }^{18}$ Artinya, "institusi terdiri dari beberapa batasan terhadap prosedur untuk mendeteksi penyimpangan dari aturan dan regulasi, dan yang terakhir beberapa norma moral dan behavioral yang mendefinisikan pola-pola (contour) yang membatasi cara aturan dan regulasi dispesifikasi dan membatasi cara pelaksanaan penegakan aturan dan regulasi itu... lembaga adalah prosedur yang membolehkan, melarang atau mengizinkan perilaku tertentu".

Deliarnov menyimpulkan bahwa bagi North kelembagaan adalah aturan-aturan dan norma-norma yang tercipta dalam masyarakat yang menentukan apa yang boleh dan tidak boleh dilakukan, mana tugas dan kewajiban yang harus dilakukan atau tidak dilakukan. Di sini terlihat bahwa North lebih memperlakukan institusi sebagai peluang sekaligus sebagai kendala eksternal bagi agen-agen ekonomi. Artinya, pelaku ekonomi boleh saja berusaha untuk memaksimumkan sesuatu, tetapi dalam upayanya tersebut agen-agen ekonomi dibatasi tidak hanya oleh sumber daya, teknologi dan preferensi-preferensi, tetapi juga oleh institusi-institusi yang ada dan berlaku dalam masyarakat. ${ }^{19}$

\footnotetext{
18 Ibid.

${ }^{19}$ Ibid. hh. 99-100.
} 
Sedangkan bagi Caporaso dan Levine, North memandang institusi sebagai batasan atau peluang yang bersifat eksternal terhadap pelaku ekonomi (tidak dapat dikendalikan pelaku ekonomi secara individu -pent). Perlakuan seperti ini sangat penting karena dengan cara itu maka telaah yang dilakukan berdasarkan definisi itu tetap bisa memfokuskan analisis terhadap individu dengan menggunakan hipotesis perilaku maksimalisasi keuntungan pribadi dan yang bisa berubah hanya biaya dan keuntungan dari berbagai alternatif tindakan. Individu akan memaksimalkan keuntungan sesuai dengan distribusi dari sumber daya, teknologi, pilihan dan pengaturan institusional yang ada. Artinya adalah bahwa semua variabel yang digunakan di sini adalah variabel-variabel yang sebelumnya sudah ada dalam persamaan dasar ekonomi ditambah satu variabel baru yaitu institusi atau pengaturan institusional. ${ }^{20}$ Sehingga, analisis ekonomi terhadap institusi memfokuskan pada cara-cara bagaimana institusi bisa memupuk perilaku instrumental (perilaku untuk mencapai tujuan tertentupent) yang kooperatif, mengurangi atau menambah biaya transaksi dan memberikan landasan organisasional bagi produksi dan pertukaran. Fokusnya adalah pada hubungan antara institusi dengan efisiensi, yaitu pada cara bagaimana institusi dapat memfasilitasi atau menghambat kegiatan pemenuhan kebutuhan pribadi. ${ }^{21}$

Menurut Deliarnov pandangan North sangat berbeda dengan pandangan pakar ekonomi politik kelembagaan lain seperti Veblen. Veblen mengartikan institusi sebagai norma-norma, nilai-nilai, tradisi dan

\footnotetext{
${ }^{20}$ James A. Caporaso dan David P. Levine, (2008), Teori-Teori Ekonomi Politik, Yogyakarta: Pustaka Pelajar, h. 361.

${ }^{21}$ Ibid. h. 362.
} 
budaya. Sedangkan bagi North, institusi adalah peraturan perundangundangan berikut sifat-sifat memaksa (enforcement) dari peraturanperaturan tersebut serta norma-norma perilaku yang membentuk interaksi antara manusia secara berulang-ulang. North menganalogikan institusi sebagai aturan permainan sedangkan organisasi adalah sebagai tempat bermain bagi sekumpulan orang. Dalam sebuah permainan, setiap pemain mempunyai tujuan yang sama, yaitu bagaimana memenangkan permainan. Akan tetapi, dalam upaya memenangkan permainan tersebut ada rambu-rambu yang tidak boleh dilanggar dan ada aturan-aturan yang harus diikuti. ${ }^{22}$

Penyimpangan aturan main akan menyebabkan sistem berjalan tidak normal. Dengan demikian, institusi selain harus dipandang sebagai aturan permainan, juga merupakan pondasi utama sistem modern, sebab baik atau buruknya sistem ekonomi dan politik sangat ditentukan oleh peran dan fungsi kelembagaan yang membingkainya. Selama institusi tidak dibenahi, berbagai masalah yang muncul dalam masyarakat akan sulit diselesaikan. Dengan demikian, untuk mengatasi berbagai masalah yang ada, North merekomendasikan institusi inilah yang pertama-tama harus dibangun, direkaya, direkonstruksi, dikembangkan, dijaga kebekerjaannya, serta ditegakkan aturan mainnya oleh berbagai pihak terkait. $^{23}$

Deliarnov menyatakan bahwa hal yang sama berlaku dalam dunia ekonomi dan bisnis, dimana ada aturan main yang mengkoordinasi

${ }^{22}$ Deliarnov, 2006, op. cit. h. 100.

23 Ibid. 
aktivitas-aktivitas ekonomi. Pasar hanya dapat bekerja dengan efektif bila ditopang oleh institusi yang tepat, dan adanya institusi pada gilirannya akan mengurangi unsur ketidakpastian. North (1994) menyatakan bahwa "... they reduce uncertainty by providing a structure to political, social and economic exchange". Pernyataan North di atas menjawab pertanyaan tentang bagaimana kelembagaan dapat mengurangi unsur ketidakpastian dalam ekonomi dan bisnis. Dari pernyataan North di atas dapat dijelaskan bahwa adanya institusi yang baik akan dapat menyelesaikan masalah koordinasi dan produksi, sebab masalah koordinasi dan produksi terkait dengan motivasi para aktor, lingkungan dan kemampuan pemain dalam ‘menjinakkan' lingkungan. ${ }^{24}$

Menurut Caporaso dan Levine, dalam kerangka pendekatan ini institusi dipahami sebagai aturan atau prosedur yang menetapkan, yaitu melarang atau memperbolehkan perilaku tertentu. Institusi politik bisa menetapkan barang-barang apa yang boleh dipertukarkan, menetapkan aturan-aturan bagi proses pertukaran dan menetapkan hak-hak kepemilikan apa yang berlaku untuk keuntungan dan tanggungan/liabilitas. Aspek politik dari institusi politik terletak pada asal muasalnya yaitu berasal dari atau ditetapkan oleh negara dan juga terletak pada adanya penggunaan kekuasaan atau kewenangan atau sanksi dari negara untuk menegakkan ketetapan-ketetapan yang mengatur perilaku itu. ${ }^{25}$

\footnotetext{
24 James A. Caporaso dan David P. Levine, 2008, op. cit. h. 362.

25 Ibid. hh. 362-363.
} 
Pendekatan ekonomi terhadap institusi ini juga bisa dipahami dengan cara dibandingkan dengan pendekatan-pendekatan sosiologis, maka mungkin institusi politik akan lebih mudah dipahami jika dibandingkan dengan pasar. Ide tentang perilaku pasar memandang bahwa individu-individu akan berusaha memenuhi kebutuhan atau kepentingan mereka dalam sebuah konteks di mana ada banyak pelaku lain yang saling mempertemukan barang yang bisa atau boleh dipertukarkan (alienable goods). Berapa nilai dari barang-barang yang dipertukarkan ini akan tergantung pada interaksi antara tingkat kelangkaan relatif dan pilihan-pilihan relatif yang ada. Institusi politik juga memberikan peluang dan batasan, tapi itu dilakukan lewat kebijakankebijakan yang bersifat wajib dipatuh (authoritariative) yang bisa mengubah besaran biasaya. ${ }^{26}$

Arifin dan Rachbini (2001) menyatakan bahwa penelusuran yang mendalam tentang ekonomi politik kelembagaan biasanya didekati dengan format dan pola hubungan antara swasta, masyarakat, organisasi buruh, partai politik, pemerintah, lembaga konsumen dan sebagainya. ${ }^{27}$ Keberadaan pekerja migran Indonesia sebagai individu yang berorientasi terhadap maksimalisasi keuntungan. Orientasi ini seringkali melanggar aturan-aturan yang telah ditetapkan sehingga penyimpanganpenyimpangan seperti TKI/PMI ilegal atau tidak berdokumen di negara penempatan hingga WNI yang menjadi korban perdagangan manusia terjadi. Oleh karena itu dibutuhkan sinergitas dan optimalisasi peran

\footnotetext{
${ }^{26}$ Ibid.

${ }^{27}$ Deliarnov, 2006, op. cit. h. 123.
} 
pemerintah, swasta dan masyarakat sipil untuk memenuhi hak-hak pekerja migran Indonesia, lebih spesifik pekerja migran asal sulawesi selatan.

\subsubsection{Peran Pemerintah}

Perekonomian tidak bisa hanya diserahkan pada produsen dan konsumen yang berinteraksi satu sama lain melalui mekanisme pasar. Di sana sini diperlukan adanya campur tangan pemerintah. Campur tangan pemerintah diperlukan jika mekanisme pasar tidak bekerja dengan sempurna. Selain itu, campur tangan pemerintah diperlukan untuk mengatasi eksternalitas dan untuk pengadaan barang-barang publik. Adapun berbagai keputusan yang menyangkut kebijakan publik dilaksanakan oleh pemerintah sesuai institusi ekonomi dan politik yang ada. Dari uraian tersebut, jelas ada hubungan antara ekonomi politik kelembagaan dengan kebijakan publik. ${ }^{28}$

Kebijakan publik sendiri terkait dengan transaksi institusional yang mendefinisikan kembali domain pilihan keputusan. Lebih jelas, transaksi institusional adalah sebuah kelas tentang perilaku ekonomi sehubungan dengan pengaturan kelembagaan, dan dengan demikian juga terkait dengan perangkat-perangkat pilihan yang membatasi arena pilihan bagi agen-agen yang memaksimumkan kepuasan individu. Dalam hal ini, ada empat jenis transaksi institusional yang menentukan domain pilihan keputusan pelaku-pelaku ekonomi. Pertama, terkait dengan hal-hal di mana perubahan institusi akan meningkatkan efisiensi produktif ekonomi.

${ }^{28}$ Ibid. 
Kedua, terkait dengan hal-hal di mana distribusi pendapatan secara sengaja ditingkatkan, apapun alasannya. Ketiga, terkait dengan relokasi kesempatan ekonomi dan keempat, terkait dengan redistribusi keuntungan ekonomi. ${ }^{29}$

Dua transaksi institusional yang disebutkan pertama, yaitu meningkatkan efisiensi dan distribusi pendapatan, sudah lama dikenal dalam ekonomi kesejahteraan. Akan tetapi, dua transaksi institusional yang lainnya merupakan hal-hal baru, yang mencerminkan aspek dominan kebijakan publik. Dalam pembahasan selanjutnya, kita akan lebih banyak membahas dua transaksi yang disebutkan terakhir, yaitu transaksi yang terkait dengan relokasi kesempatan ekonomi dan transaksi yang terkait dengan redistribusi keuntungan ekonomi. Ekonomi politik kelembagaan lebih banyak berhubungan dengan kebijakan publik, baik yang sifatnya ex-post maupun ex-ante. Dalam analisisnya, ekonomi politik kelembagaan lebih banyak diarahkan untuk menjelaskan suatu hasil akhir dari suatu pola interaksi aktivitas perekonomian. ${ }^{30}$

Perlunya campur tangan pemerintah, terutama yang menyangkut kebijakan publik dikarenakan adanya beberapa hal yang menyebabkan pasar tidak bekerja semestinya. Lewat campur tangan pemerintah, mekanisme koordinasi penyediaan barang-barang dan jasa dilaksanakan melalui hierarki yang dilakukan berdasarkan perintah dan kontrol oleh pemegang otoritas dan kewenangan. Menurut Bromley (1989), "public policy is essentially about the structure of institutional arrangements that

\footnotetext{
29 Ibid.

30 Ibid.
} 
define individual and group choice sets". Artinya, masalah kebijakan publik terkait dengan perubahan dalam aransemen kelembagaan. ${ }^{31}$ Arifin dan Rachbini (2001) juga menyatakan bahwa pembahasan ekonomi politik kelembagaan jelas terkait dengan kebijakan publik, mulai dari proses perancangan, perumusan, sistem organisasi dan implementasi kebijakan publik yang salah satu aktornya adalah pemerintah. ${ }^{32}$

Kebijakan publik (public policy) dari pandangan para pakar didefinisikan sebagai berikut. Harold Laswell dan Abraham Kaplan (1970:71) menyatakan sebagai suatu program yang diproyeksikan dengan berbagai tujuan, nilai dan praktik tertentu (a projected programs of goals, values and practices). David Easton (1965:212) menyatakan a relative stable, purposive course of action followed by an actor or set of actors in dealing with a problem or matter of concern. Sedangkan, Kraft dan Furlong (2004:4): menyatakan a course of government action (or inaction) taken in response to social problems. Social problems are conditions the public widely perceives to be unacceptable and therefore requiring intervention. ${ }^{33}$

Selanjutnya, James Lester dan Robert Steward (2000:18) menyatakan a process or a series or pattern of governmental activities or decisions that are design to remedy some public problem, either real or imagined. Austin Ranney (dikutip Lester dan Steward, 2000:18) menyatakan a selected line of action or declaration of inten. Steve A. Peterson (2003:103) menyatakan government action to address some

${ }^{31}$ Ibid. h. 125.

32 Ibid. h. 123.

${ }^{33}$ Riant Nugroho, 2013, Metode Penelitian Kebijakan, Yogyakarta: Pustaka Pelajar. h. 3. 
problem. B. G. Peters (1993:4) menyatakan the sum of government activities, whether acting directly of through agents, as it has an influence on the lives of citizens. Sedangkan, Carl I. Friedrick (1963:79) mendefinisikannya sebagai serangkaian tindakan yang diusulkan seseorang, kelompok atau pemerintah dalam suatu lingkungan tertentu dengan ancaman dan peluang yang ada, di mana kebijakan yang diusulkan tersebut ditujukan untuk memanfaatkan potensi sekaligus mengatasi hambatan yang ada dalam rangka mencapai tujuan tertentu. ${ }^{34}$

Kemudian, William Jenkins (1978) menyatakan bahwa kebijakan publik sebagai a set of interrelated decision taken by a political actor or group of actors concerning the selection of goals and the means of achieving them within a specified situations where those decisions should in principle, be within the power of those actors to achieve... public policy is a goal oriented behavior on the part of government... public policies are decisions taken by government which define a goal and set our means to achieve it. Sedangkan, Michael Howlett dan M. Ramesh (1995:7) mengemukakan bahwa public policy is a complex phenomenon consisting of numerous decisions made by numerous individual and organizations. It is often shaped by earlier policies and is frequently linked closely with other seemingly unrelated decisions. ${ }^{35}$

Definisi lainnya dikemukakan oleh Thomas R. Dye (2011:1) yang mendefinisikan kebijakan publik sebagai segala sesuatu yang dikerjakan pemerintah, mengapa mereka melakukan dan hasil yang membuat

\footnotetext{
34 Ibid. hh. 3-4.

35 Ibid. h. 4.
} 
sebuah kehidupan bersama tampil berbeda (public policy is "whetever governments choose to do or not to do. Public policy is what government do, why they do it and what difference it makes"). Clarke E. Cochran menggambarkan bahwa the term public policy always refers to the actions of government and the intentions that determine those actions. Public policy is the outcome of the struggle in government over who gets what. Sedangkan, Thomas Birkland (2001) mengemukakan bahwa ... the elements common to all definitions of public policy are as follows: (1) the policy is made in the name of the "public", (2) policy is generally made or initiated by government, (3) policy is interpreted and implemented by public and private actors, (4) policy is what the government intends to do, dan (5) policy is what the government chooses not to do. ${ }^{36}$

Stella Theodoulou (2005) mengemukakan bahwa ... the public policy process is essentially movement from the emergence of a problem, to it being placed on to the policy agenda and finally, to its enactment and reflection on its effectiveness. The public policy process may be thus broken up into six fluid stages, as follows: (1) problem recognition: problems that may potentially make their way onto the public policy agenda are recognized; (2) agenda setting: problems that are deemed worthy of attention are placed on the agenda; (3) policy formulation: various policies are crafted to deal with the problem that has been set on the agenda; (4) policy adoption: an official policy is agreed upon; (5) policy implementation: the public policy that has been officially agreed upon is

\footnotetext{
${ }^{36}$ Ibid. hh. 4-5.
} 
put into action; dan (6) policy analysis and evaluation: the implemented policy is evaluated for its effectiveness. Daniel C. McCool (1995:4) mengemukakan bahwa while the study of politics has a long history. The systematic study of public policy, on the other hand, can be said to be twentieth century creation. It dates to 1922, when political scientist Charles Merriam sought to connect the theory and practices of politics to understanding the actual activities of government, that is public policy. ${ }^{37}$

Definisi tentang kebijakan publik telah dipaparkan di atas dan tidak ada dari satu definisi tersebut yang keliru, semuanya benar dan saling melengkapi. Hanya satu hal yang perlu dicatat, beberapa ilmuwan sosial di Indonesia menggunakan istilah kebijaksanaan sebagai kata ganti policy. Perlu ditekankan, kebijaksanaan bukanlah kebijakan, karena kebijaksanaan adalah salah satu ciri dari kebijakan publik yang unggul.

Namun demikian untuk merangkum definisi di atas, maka Riant Nugroho (2013:6-7) merumuskan definisi sederhana. Pertama, kebijakan terbentuk dari dua kata: kebijakan dan publik. Kebijakan (policy) adalah an authoritative decision. Decision made by the one who hold the authority, formal and informal. Publik adalah sekelompok orang yang terikat dengan suatu isu tertentu. Jadi, "publik" bukanlah umum, rakyat, masyarakat atau sekedar stakeholders. Publik adalah a sphere where people become citizen, a space where citizens interact, where state and society exist. Jadi public policy adalah "... any of state or government (as the holder of the authority) decision to manage public life (as the sphere) in order to reach

${ }^{37}$ Ibid. hh. 5-6. 
the mission of the nation (remember, nation is consist of two institutions: state and society)". Secara sederhana dapat dikatakan bahwa kebijakan publik adalah: “... setiap keputusan yang dibuat oleh Negara, sebagai strategi untuk merealisasikan tujuan dari Negara. Kebijakan publik adalah strategi untuk mengantar masyarakat pada masa awal, memasuki masyarakat pada masa transisi, untuk menuju kepada masyarakat yang dicita-citakan". ${ }^{38}$

Kebijakan publik dalam penelitian ini dimaknai sebagai kebijakan/aturan yang mengatur proses migrasi pekerja Indonesia ke luar negeri meliputi kebijakan payung yang diatur dalam UU No. 39 Tahun 2004 tentang Penempatan dan Perlindungan Tenaga Kerja Indonesia di Luar Negeri dan kebijakan turunan yang meliputi: Peraturan Pemerintah, Peraturan Presiden, Peraturan Menteri, Peraturan Kepala Badan maupun Peraturan Daerah. Peraturan-peraturan yang dihimpun dalam penelitian ini dikelompokkan berdasarkan pembahasan mengenai pemenuhan hakhak pekerja migran Indonesia pada masa pra-penempatan, masa penempatan dan purna-penempatan. Namun dalam penelitian ini secara spesifik peneliti memfokuskan pada dua tahapan yakni masa prapenempatan dan masa penempatan.

Salah satu model yang sering digunakan dalam analisis ekonomi politik, aliran kelembagaan adalah model hierarki kebijakan publik. Dalam model hierarki kebijakan publik, digunakan preposisi bahwa perubahan aransemen kelembagaan sangat berhubungan dengan hakikat, model dan

${ }^{38}$ Ibid. hh. 6-7. 
analisis kebijakan publik. Dalam model hierarki kebijakan publik ini ada tiga lapisan kelembagaan, yaitu (1) pada level konstitusi, (2) level pemerintah dan (3) level operasional. Sehubungan dengan tiga lapisan kelembagaan di atas, juga ada tiga tingkatan kebijakan publik, yaitu: (1) tingkatan kebijakan, (2) tingkatan organisasi (institusi, aturan main) dan (3) tingkatan implementasi (untuk evaluasi, umpan balik). Lebih jelas tentang model hierarki kebijakan publik ini dapat dilihat pada bagan $2.2 .^{39}$

Bagan 2.2 Model Hierarki Kebijakan Publik

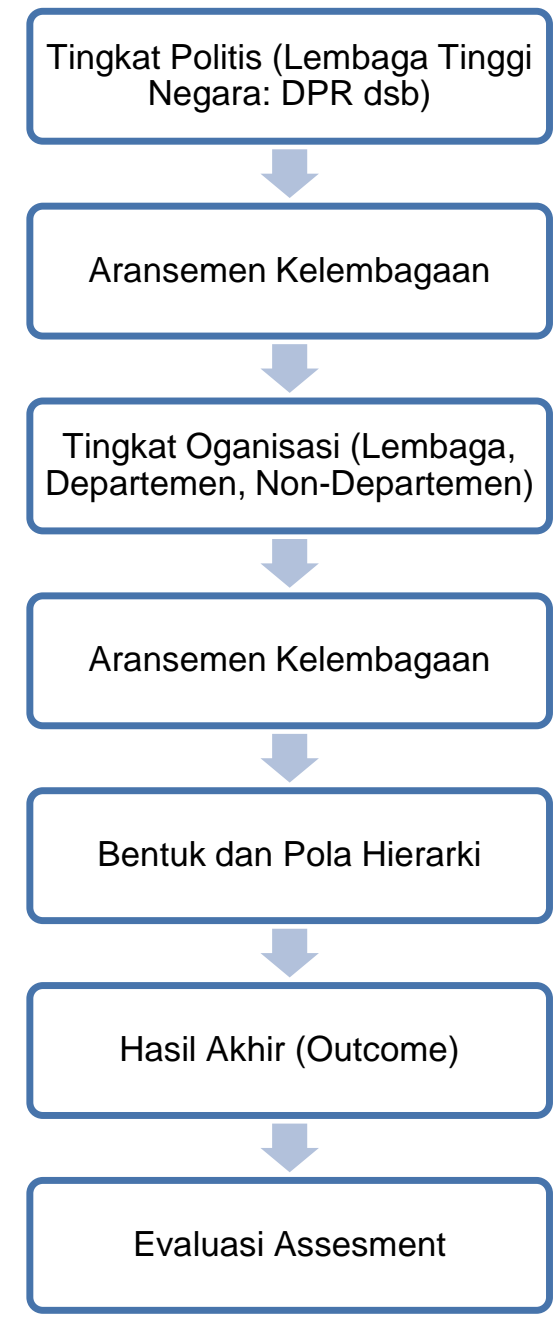

Sumber: Bromley (1989:33) dalam Deliarnov (2006:126)

39 Ibid. 
Sebuah hierarki kebijakan mengilustrasikan bahwa aransemen kelembagaan timbul dari level kebijakan dan dari level organisasional untuk membatasi perangkat-perangkat pilihan bagi agen-agen atomistik pada level operasional. Jika tindakan kolektif tersebut gagal, maka tetap digunakan aransemen institusi yang lama. Kalau berhasil, lewat tindakan kolektif dan transaksi-transaksi kelembagaan dilakukan modifikasi aransemen kelembagaan yang ada dengan yang baru. Sekali terjadi perubahan eksogen selanjutnya mensimulasi respons kelembagaannya sendiri. $^{40}$

Dalam suatu perekonomian, banyak orang dan organisasi yang terlibat dengan motivasi yang beragam. Jenis dan klasifikasinya sebagai berikut: (1) sektor swasta, umumnya bergerak dalam kegiatan komersial dan beroperasi dengan tujuan mencari keuntungan. Termasuk dalam organisasi swasta ini antara lain perusahaan, perseroan, firma dan sebagainya; (2) sektor pemerintah (publik), biasanya bergerak dalam kegiatan-kegiatan yang sifatnya memberikan pelayanan dan menjalankan aturan main, seperti lembaga negara, departemen, dinas, kantor, badan dan sebagainya; (3) organisasi masyarakat, umumnya bergerak dalam kegiatan-kegiatan yang sifatnya bukan untuk mengejar keuntungan, tetapi memperjuangkan ideologi atau nilai, seperti LSM atau organisasi nonpemerintah (ornop), kelompok tani, himpunan profesi, organisasi kemasyarakatan, dan sebagainya. Selain ketiga klasifikasi di atas, ada juga organisasi yang klasifikasinya "abu-abu" antara sektor swasta dan

\footnotetext{
${ }^{40}$ Ibid. h. 126.
} 
publik, seperti BUMN/BUMD, antara sektor swasta dan organisasi masyarakat seperti: KADIN, Serikat dan Koperasi; atau antara sektor publik dan organisasi masyarakat seperti: Universitas dan Yayasan. ${ }^{41}$

Bagan 2.3 Jenis Klasifikasi Organisasi

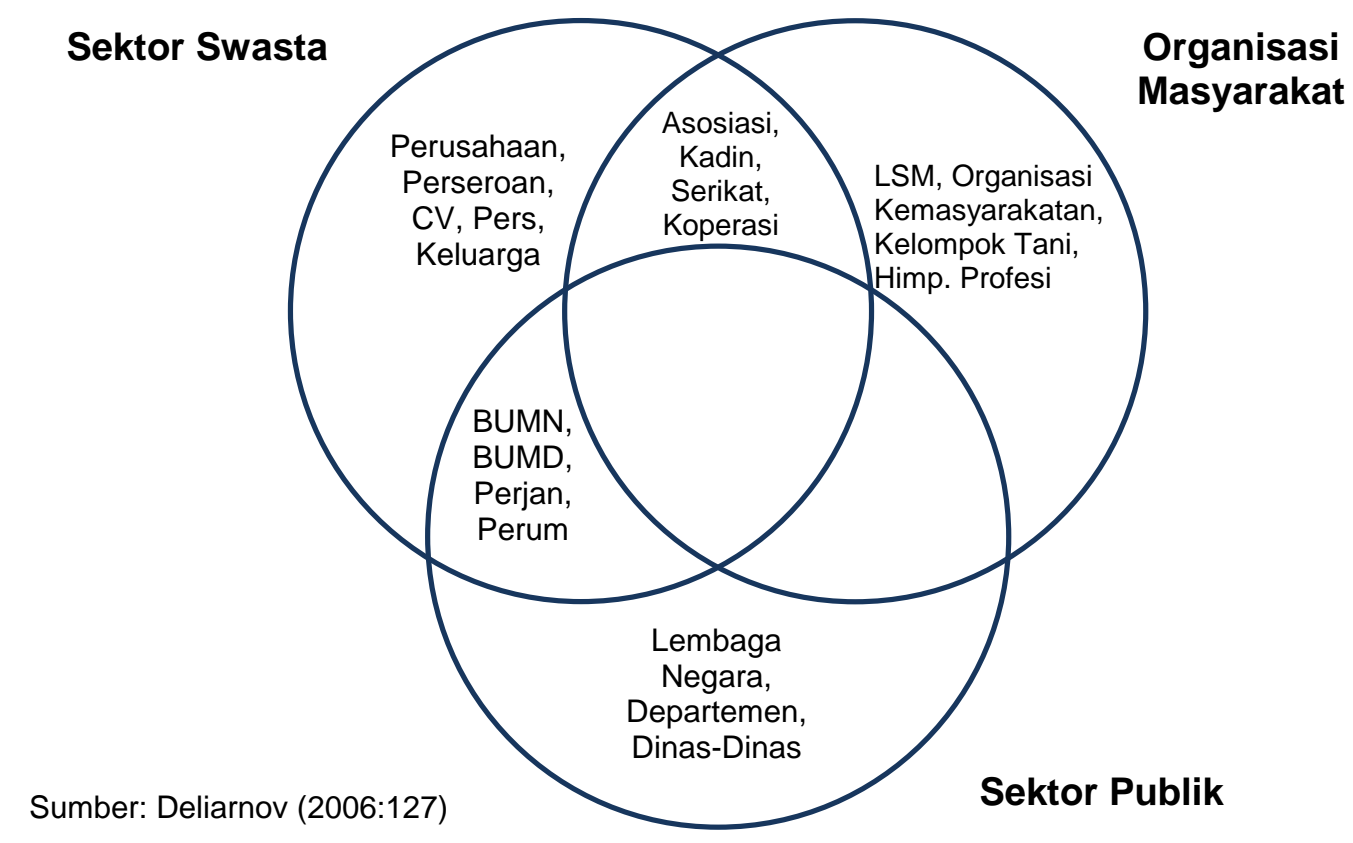

Hierarki kebijakan publik di atas menunjukkan bahwa kebijakan publik memiliki tingkatan dan klasifikasi. Tingkatan teratas dari kebijakan penempatan dan perlindungan TKI adalah UU No. 39 Tahun 2004 tentang Penempatan dan Perlindungan Tenaga Kerja Indonesia di Luar Negeri yang disahkan dengan persetujuan bersama antara Dewan Perwakilan Rakyat RI dan Presiden RI yang merupakan hierarki kebijakan publik tertinggi, kemudian kebijakan publik yang menjadi turunan adalah Peraturan Pemerintah yang membantu memberikan penjelasan dari UU No. 39/2004. Peraturan yang mengatur teknis pelaksanaan biasanya diatur oleh Menteri melalui Peraturan Menteri hingga di tingkat operasional

${ }^{41}$ Ibid. 
juga diterbitkan Peraturan Kepala BNP2TKI. Peraturan turunan dari UU No. 39/2004 maupun yang terkait akan banyak ragamnya. Hal yang ingin ditegaskan dari penjelasan di atas yakni pemerintah memegang peranan sentral dalam ekonomi politik kelembagaan.

\subsubsection{Interaksi Pemerintah dan Swasta}

Setiap agen pada semua jenis organisasi memiliki motivasi yang berbeda, yang kadang-kadang konflik satu sama lainnya. Untuk menghindari dampak yang tidak diinginkan, dalam analisis ekonomi politik kelembagaan sering dikaji apa saja keputusan atau kebijakan yang dapat memperbaiki suatu hasil dan apa pula aturan main (norma-norma, aturanaturan, hubungan kepemilikan) yang mampu memberi naungan dan sanksi terhadap tingkah laku masing-masing pihak yang terlibat dalam suatu aktivitas ekonomi. Sehubungan dengan hal tersebut, ada beberapa pilihan yang bisa diambil untuk memperbaiki kinerja dan hasil suatu sistem (perekonomian), antara lain: (1) mengubah kodrat/tingkah laku manusia sehingga tindakannya lebih terkontrol dan tidak merugikan orang lain; (2) mengubah hakikat barang/jasa (untuk itu perlu rekayasa, desain dan teknologi); dan (3) mengubah aturan main. Mengubah kodrat manusia dan hakikat barang bukan pekerjaan mudah. Oleh karena yang paling mungkin untuk dilakukan adalah mengubah aturan main. ${ }^{42}$

Aturan main sangat penting sebab perekonomian yang sehat dan berdaya saing menuntut adanya aturan tentang hukum untuk menjamin tegaknya persaingan sehat di pasar ekonomi dan pasar politik untuk

\footnotetext{
${ }^{42}$ Ibid. h. 127.
} 
mewujudkan kemakmuran yang berkeadilan. Aturan main di pasar ekonomi diperlukan untuk menjamin alokasi sumber daya yang efisien bagi sebesar-besarnya kemakmuran rakyat, sedangkan aturan main di pasar politik diperlukan untuk menjamin agar kekuasaan politik yang ada merepresentasikan berbagai kepentingan masyarakat yang berbedabeda. $^{43}$

Menurut Weber (1978), negara memiliki hak monopoli untuk menggunakan legitimasi kekuasaan dalam suatu wilayah tertentu. Monopoli untuk menggunakan legitimasi kekuasaan penting karena tidak ada negara yang mau ditantang atau diragukan perannya dalam mengorganisasi semua hal yang diperlukan untuk mencapai tujuan yang hendak dicapai. Legitimasi untuk menggunakan kekuasaan diperoleh lewat prosedur demokrasi. Hal ini, diperlukan agar populasi menerima setiap kebijakan yang diambil pemerintah. ${ }^{44}$

Tabel 2.2 Model-Model Interaksi Birokrasi (Pemerintah) dan Dunia Usaha (Swasta)

\begin{tabular}{|c|c|c|c|}
\hline No & Model & Sistem Hukum & Peraturan/Regulasi \\
\hline 1. & $\begin{array}{l}\text { Invisible } \\
\text { Hand }\end{array}$ & $\begin{array}{l}\text { Pemerintah tidak di atas } \\
\text { hukum dan menyediakan } \\
\text { sarana dan prasarana } \\
\text { dasar barang publik. } \\
\text { Sistem hukum ditegakkan } \\
\text { dan pengadilan } \\
\text { berwibawa. }\end{array}$ & $\begin{array}{l}\text { Pemerintah } \\
\text { mengeluarkan peraturan } \\
\text { dan ikut mematuhi } \\
\text { peraturan. Peran dunia } \\
\text { usaha dalam ekonomi } \\
\text { cukup besar. Korupsi } \\
\text { ada tetapi terkelola. }\end{array}$ \\
\hline
\end{tabular}

${ }^{43}$ Ibid.

${ }^{44}$ Ibid. 


\begin{tabular}{|c|l|l|l|}
\hline 2. & Helping Hand & $\begin{array}{l}\text { Pemerintah kadang di } \\
\text { atas hukum, tetapi } \\
\text { menggunakan } \\
\text { kekuatannya untuk } \\
\text { membantu dunia usaha. } \\
\text { Aparat pemerintah } \\
\text { menjadi penegak kontrak. }\end{array}$ & $\begin{array}{l}\text { Pemerintah secara } \\
\text { agresif mengeluarkan } \\
\text { peraturan untuk } \\
\text { memajukan dunia usaha. } \\
\text { Pola korupsi lebih } \\
\text { terorganisasi dengan } \\
\text { jaringan cukup rapi. }\end{array}$ \\
\hline 3. & $\begin{array}{l}\text { Grabbing } \\
\text { Hand }\end{array}$ & $\begin{array}{l}\text { Pemerintah di atas } \\
\text { hukum dan } \\
\text { menggunakan kekuatan } \\
\text { untuk memburu rente. } \\
\text { Sistem hukum tidak jalan. } \\
\text { Preman dan mafia yang } \\
\text { menjadi penegak kontrak. }\end{array}$ & $\begin{array}{l}\text { Peraturan pemerintah } \\
\text { bersifat predator dan } \\
\text { mengganggu dunia } \\
\text { usaha. Korupsi } \\
\text { umumnya tidak } \\
\text { terorganisasi, hampir } \\
\text { menjadi "norma". }\end{array}$ \\
\hline
\end{tabular}

Sumber: Bustanul Arifin, dari Materi Kuliah Ekonomi Politik dan Kebijakan Publik dalam Deliarnov (2006:128)

Negara adalah simbol pemegang kekuasaan. Otoritas terjelma dalam bentuk kekuatan. Dengan kekuasaan yang ada di tangan, orang bisa melakukan apa saja, termasuk menggunakan kekuasaan untuk kepentingan diri sendiri dan kelompok. Dalam kenyataan, kekuasaan memang sangat menggoda. Siapa pun, kapan pun, dimana pun pada setiap jenjang kekuasaan, selalu ada kecenderungan untuk menyalahgunakan kekuasaan. Yang diharapkan ialah bahwa kekuasaan digunakan untuk menegakkan keadilan (seperti dalam model invisible hand) atau penegak kontrak (model helping hand), bukan malah digunakan untuk memburu rente (model grabbing hand). Lihat Tabel 2.2. ${ }^{45}$

Walau bisa digunakan untuk hal-hal yang membawa dampak negatif, kekuasaan tetap diperlukan, sebab hanya dengan kekuasaanlah keadilan bisa ditegakkan. Oleh karena fungsi kekuasaan tidak tergantikan, yang dapat dilakukan ialah membingkainya sedemikian rupa, sehingga dapat meminimalisasi penyalahgunaan kekuasaan itu sendiri. Begitu juga

\footnotetext{
${ }^{45}$ Ibid. h. 128.
} 
di pasar ekonomi harus ada otoritas yang menjamin tegaknya keadilan dan ketertiban. Walau pasar tidak suci, perannya tidak tergantikan oleh mekanisme apa pun. Agar bisa berperan optimal, seperti halnya kekuasaan, pasar harus dibingkai dalam suatu aturan main. Dengan ditegakkannya aturan main, diharapkan perekonomian dengan menyelesaikan masalah-masalah ekonomi yang dihadapi sekaligus mencapai tujuan bersama. ${ }^{46}$

Aturan main dalam penempatan dan perlindungan TKI adalah negara (pemerintah) berperan sebagai fasilitator untuk memberangkatkan TKI ke luar negeri, di sisi lain pemerintah juga sebagai regulator, sedangkan pihak yang merekrut TKI dari berbagai daerah adalah perusahaan swasta (PPTKIS) yang berorientasi terhadap perolehan keuntungan. Pemenuhan hak-hak pekerja migran sulit diwujudkan apabila pemerintah masih longgar dalam menetapkan aturan penempatan dan perlindungan TKI terhadap PPTKIS selaku pihak swasta. Penyimpangan yang dilakukan oleh PPTKIS terhadap pemenuhan hak-hak dasar TKI pada masa pra-penempatan berpotensi untuk menimbulkan permasalahan pada masa penempatan. Sehingga kebijakan penempatan dan perlindungan TKI harus dilihat secara komprehensif dari setiap tahapannya.

\subsubsection{Peran Masyarakat Sipil}

Kelembagaan (dan aransemen kelembagaan) yang efisien dapat menurunkan biaya transaksi secara signifikan, baik di pasar ekonomi

\footnotetext{
${ }^{46}$ Ibid.
} 
maupun pasar politik. Persoalan menjadi pelik ketika kelembagaan yang efisien itu tidak dirancang, diorganisasi dan ditegakkan dengan baik oleh pemerintahan yang ada. Dalam situasi seperti inilah diharapkan kehadiran masyarakat sipil (civil society, yang tahu akan hak-hak dan kewajibannya) yang menghendaki harmoni dan keberadaban. ${ }^{47}$

Masyarakat sipil harus peduli terhadap kelembagaan sebab kelembagaanlah yang menentukan aturan main dan mengkoordinasikan aktivitas di pasar ekonomi maupun pasar politik. Agar dapat menjalankan perannya dengan baik, masyarakat sipil seyogyanya didukung oleh individu-individu, LSM dan orang-orang pemikir dari kalangan perguruan tinggi. Untuk menjalankan perannya, masyarakat sipil memerlukan kekuatan. Agar memperoleh kekuatan yang efektif, sebaiknya masyarakat sipil tergabung dalam partai politik; pressure group; kelompok kepentingan dan minimal berperan dalam pendidikan politik. Jika memiliki kekuatan, masyarakat sipil bisa "memaksakan" dibentuknya sistem hukum yang dapat diandalkan dan bebas dari tekanan politik, birokrasi yang bersih dan kepemimpinan yang kuat. ${ }^{48}$

Peran masyarakat sipil dalam pemenuhan hak-hak pekerja migran dapat dilihat dari peran aktif dari CTKI/TKI/TKI Purna sebagai individu dalam memahami 'aturan main', demikian juga dengan peran kelembagaan dari Lembaga Swadaya Masyarakat (LSM) yang turut mengadvokasi hak-hak pekerja migran. Peran akademisi juga diperlukan untuk melakukan kajian akademik agar permasalahan dan pemenuhan

\footnotetext{
${ }^{47}$ Ibid.

${ }^{48}$ Ibid. h. 129.
} 
hak-hak pekerja migran dapat diakomodasi dalam kebijakan yang dibuat pemerintah. Oleh karena itu, masyarakat sipil dalam kaitannya dengan penempatan dan perlindungan TKI menempati posisi yang signifikan untuk perubahan "aturan main" yang lebih berpihak pada penegakan hak asasi manusia (HAM) pekerja migran.

\subsection{Ekonomi Politik Sektoral}

Ekonomi politik sektoral merupakan salah satu instrumen dalam analisis ekonomi politik. Organization for Economic Cooperation and Development - Development Assistance Committee (OECD-DAC) mendefinisikan analisis ekonomi politik sebagai berikut: "Political economy analysis is concerned with the interaction of political and economic processes in a society: the distribution of power and wealth between different groups and individuals, and the processes that create, sustain and transform these relationships over time". Artinya, analisis ekonomi politik berkaitan dengan interaksi proses politik dan ekonomi di masyarakat: distribusi kekuasaan dan kekayaan antara kelompok dan individu, dan proses yang menciptakan, mempertahankan dan mentransformasikan hubungan ini dari waktu ke waktu. ${ }^{49}$

Definisi ini menitikberatkan pada aspek politik yang dapat dipahami dalam hal kontestasi dan tawar-menawar antara kelompok-kelompok kepentingan dengan klaim antara hak-hak dan sumber daya. Namun, sama-sama fokus pada proses ekonomi yang menghasilkan kekayaan, dan bagaimana pengaruh pilihan politik yang dibuat. Pada kenyataannya

\footnotetext{
${ }^{49}$ Department for International Development, 2009, Political Economy Analysis: How to Note - http://www.gsdrc.org/docs/open/po58.pdf, diakses 3 Maret 2016.
} 
proses ini erat hubungannya dan bagian dari kesatuan terpadu dari dinamika yang mempengaruhi luaran pembangunan. ${ }^{50}$

Analisis ekonomi politik dibagi ke dalam tiga jenis antara lain: (1) Analisis negara tingkat makro (macro-level country analysis) digunakan untuk meningkatkan sensitivitas umum ke konteks negara dan pemahaman tentang lingkungan politik-ekonomi yang luas; (2) analisis tingkat sektoral (sector-level analysis) digunakan untuk mengidentifikasi hambatan tertentu dan kesempatan dalam sektor-sektor tertentu; dan (3) analisis berbasis masalah (problem-driven analysis) diarahkan untuk memahami dan menyelesaikan masalah tertentu di tingkat proyek atau dalam kaitannya dengan masalah kebijakan tertentu. ${ }^{51}$

Analisis ekonomi politik yang digunakan dalam penelitian ini adalah analisis tingkat sektoral (sector-level analysis). Analisis ekonomi politik di tingkatan ini berguna untuk membantu menjelaskan mengapa reformasi di area seperti: pendidikan, kesehatan dan infrastruktur (maupun ketenagakerjaan) terhambat; apa insentif dan kendala yang mempengaruhi politisi, pegawai negeri sipil (PNS) dan reformis lainnya di sektor ini. Hampir semua analisis sektoral melibatkan pemetaan awal pemangku kepentingan utama, seperti bagan 2.4 berikut:

50 Ibid.

${ }^{51}$ Ibid. 
Bagan 2.4 Peta Pemangku Kepentingan Sektoral

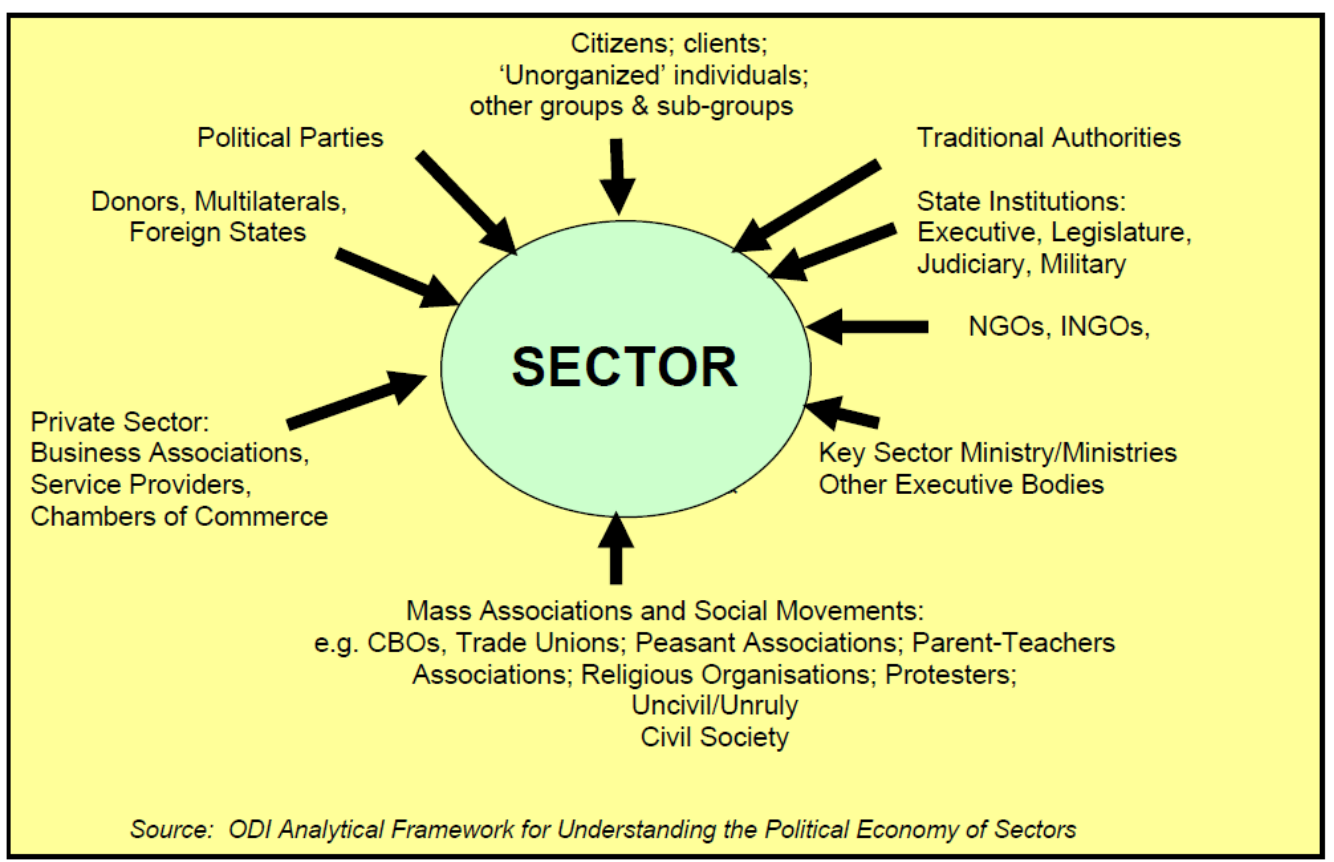

Setelah pemangku kepentingan (stakeholders) diidentifikasi, tahap selanjutnya adalah mendalami siapa aktor yang paling berpengaruh dan apa kepentingan dan insentif dan bagaimana aktor ini membentuk dinamika di dalam sektor, termasuk kelayakan reformasi kebijakan yang diusulkan. Hal ini dirilis oleh Overseas Development Institute (ODI) dalam ODI Analytical Framework for Conducting Political Economy Analysis in Sectors; World Bank Problem Driven Governance and Political Economy Analysis. Analisis ekonomi politik tingkat sektoral merupakan instrumen/alat bantu yang digunakan dalam penelitian ini untuk memetakan interaksi antar pemangku kepentingan dalam sektor ketenagakerjaan antar-negara (Indonesia-Malaysia).

\subsection{Hak-Hak Pekerja Migran Indonesia}

Pemerintah (negara) hadir dalam proses migrasi pekerja Indonesia ke luar negeri merupakan amanat Undang-Undang Dasar (UUD) 1945 
Pasal 27 Ayat 2 yang menyatakan jaminan terhadap hak setiap warga negara untuk memperoleh pekerjaan. Hal ini kemudian dipertegas dalam UUD 1945 (hasil amandemen kedua) Bab XA tentang Hak Asasi Manusia (Pasal 28A-28J). Pasal 28 D mengamanatkan bahwa "setiap orang berhak untuk bekerja serta mendapatkan imbalan dan perlakuan yan adil dan layak dalam hubungan kerja". Selanjutnya dalam pasal 28 I ayat 4 menegaskan bahwa perlindungan (protection), pemajuan (furtherance), penegakan (enforcement), dan pemenuhan (fulfillment) hak asasi manusia adalah tanggungjawab negara dalam hal ini pemerintah. Selanutnya, UU No. 29 Tahun 1999 tentang Hak Asasi Manusia (HAM) dalam Pasal 39 ayat 2 juga menyatakan bahwa: "setiap orang berhak dengan bebas memilih pekerjaan yang disukainya dan berhak pula atas syarat-syarat ketenagakerjaan yang adil". Sedangkan, dalam pasal 71 mengatur mengenai tanggungjawab pemerintah untuk menghormati, melindungi, menegakkan, dan memajukan hak asasi manusia baik yang diatur dalam undang-undang maupun hukum internasional.

Pelaksanaan amandemen kedua dengan dimasukkannya nilai HAM pada UUD 1945 merupakan upaya mempertegas komitmen Indonesia terhadap pemajuan dan perlindungan HAM dengan mengintegrasikan ketentuan-ketentuan penting dari instrumen-intrumen internasional mengenai HAM, sebagaimana tercantum dalam Bab XA tentang Hak Asasi Manusia. Sehingga ditetapkannya HAM dalam bab tersendiri di dalam UUD 1945, pemerintah menunjukkan komitmen bangsa Indonesia untuk menghormati, mengakui, dan melindungi hak-hak asasi manusia. 
Landasan konstitusional sebagaimana disebutkan di atas mengenai hak atas pekerjaan (right to work) dan hak dalam bekerja (rights in work) merupakan hak asasi manusia (HAM). Keduanya memang kelihatan sama, namun secara prinsip berbeda. Pemenuhan hak atas pekerjaan lebih menitikberatkan akses dunia kerja tanpa diskriminasi atas dasar agama, etnis dan sebagainya, sementara pemenuhan hak dalam bekerja adalah implementasi pemenuhan hak-hak normatif bagi pekerja seperti gaji, fasilitas keamanan dan keselamatan, serta masa depan mereka (jaminan hari tua). Konsekuensinya adalah negara wajib memberikan fasilitas keterbukaan dan ketersediaan lapangan kerja berikut juga memberikan ruang aktualisasi kehidupan bermartabat dalam dunia kerja. $^{52}$

Undang-undang yang mengatur tentang penempatan TKI di luar negeri diawali Ordonansi tentang Pengerahan Orang Indonesia untuk Melakukan Pekerjaan di Luar Negeri (Staatsblad Tahun 1887 No. 8) yang berasal dari aturan Belanda. Pasca kemerdekaan, aturan tersebut hanya ditambahkan dengan berbagai Peraturan Menteri sebagai petunjuk pelaksanaan. Sehingga jika dibandingkan dengan UU, maka aturan tersebut tentunya memiliki kekuatan hukum yang lemah. Perhatian pemerintah di bidang ketenagakerjaan baru dilakukan sejak reformasi hukum di bidang ketenagakerjaan dengan disahkannya Undang-Undang No. 13 Tahun 2003 tentang Ketenagakerjaan. Dengan hadirnya UU tersebut, maka Ordonansi tentang Pengerahan Orang Indonesia untuk

\footnotetext{
52 Majda El Muhtaj. 2013. Dimensi-Dimensi HAM: Mengurai Hak Ekonomi, Sosial dan Budaya. Jakarta: Rajawali Pers. hh. 179-180.
} 
Melakukan Pekerjaan di Luar Negeri dinyatakan tidak berlaku lagi dan diamanatkan agar penempatan tenaga kerja ke luar negeri diatur dengan undang-undang tersendiri. Menindaklanjuti amanat UU 13/2003 tersebut, maka pada tahun 2004, disahkan sebuah UU yang mengatur tentang mekanisme penempatan dan perlindungan TKI di luar negeri yakni UU No. 39 Tahun 2004 tentang Penempatan dan Perlindungan TKI di Luar Negeri. ${ }^{53}$

UU No. 39 Tahun 2004 dalam bagian pertimbangan menekankan aspek pemenuhan hak-hak asasi manusia sebagai inti dari pelaksanaan penempatan dan perlindungan TKI di luar negeri, selengkapnya sebagai berikut: (a) bahwa bekerja merupakan hak asasi manusia yang wajib dijunjung tinggi, dihormati, dan dijamin penegakannya; (b) bahwa setiap tenaga kerja mempunyai hak dan kesempatan yang sama tanpa diskriminasi untuk memperoleh pekerjaan dan penghasilan yang layak, baik di dalam maupun di luar negeri sesuai dengan keahlian, keterampilan, bakat, minat, dan kemampuan; (c) bahwa tenaga kerja Indonesia di luar negeri sering dijadikan obyek perdagangan manusia, termasuk perbudakan dan kerja paksa, korban kekerasan, kesewenang wenangan, kejahatan atas harkat dan martabat manusia, serta perlakuan lain yang melanggar hak asasi manusia; (d) bahwa negara wajib menjamin dan melindungi hak asasi warga negaranya yang bekerja baik di dalam maupun di luar negeri berdasarkan prinsip persamaan hak,

53 Achmad Zulfikar. (2013). Alasan Pemerintah Indonesia Meratifikasi Konvensi Internasional Perlindungan Hak Pekerja Migran Tahun 2012. Skripsi. Universitas Muhammadiyah Yogyakarta. hh. 41-42. 
demokrasi, keadilan sosial, kesetaraan dan keadilan gender, anti diskriminasi, dan anti perdagangan manusia.

UU No. 39/2004 ini juga menyebutkan: (e) bahwa penempatan tenaga kerja Indonesia di luar negeri merupakan suatu upaya untuk mewujudkan hak dan kesempatan yang sama bagi tenaga kerja untuk memperoleh pekerjaan dan penghasilan yang layak, yang pelaksanaannya dilakukan dengan tetap memperhatikan harkat, martabat, hak asasi manusia dan perlindungan hukum serta pemerataan kesempatan kerja dan penyediaan tenaga kerja yang sesuai dengan kebutuhan nasional; dan (f) bahwa penempatan tenaga kerja Indonesia di luar negeri perlu dilakukan secara terpadu antara instansi Pemerintah baik Pusat maupun Daerah dan peran serta masyarakat dalam suatu sistem hukum guna melindungi tenaga kerja Indonesia yang ditempatkan di luar negeri.

Hak dan kewajiban TKI secara eksplisit disebutkan dalam Bab III Pasal 8-9 UU No. 39/2004 sebagai berikut. Setiap calon TKI mempunyai hak dan kesempatan yang sama untuk: (a) bekerja di luar negeri; (b) memperoleh informasi yang benar mengenai pasar kerja luar negeri dan prosedur penempatan TKI di luar negeri; (c) memperoleh pelayanan dan perlakuan yang sama dalam penempatan di luar negeri; (d) memperoleh kebebasan menganut agama dan keyakinannya serta kesempatan untuk menjalankan ibadah sesuai dengan agama dan keyakinan yang dianutnya; (e) memperoleh upah sesuai dengan standar upah yang berlaku di negara tujuan; (f) mempeoleh hak, kesempatan dan perlakuan 
yang sama yang diperoleh tenaga kerja asing lainnya sesuai dengan peraturan perundang-undangan di negara tujuan; (g) memperoleh jaminan perlindungan hukum sesuai dengan peraturan perundang-undangan atas tindakan yang dapat merendahkan harkat dan martabatnya serta pelanggaran atas hak-hak yang ditetapkan sesuai dengan peraturan perundang-undangan selama penempatan di luar negeri.

Hak TKI selanjutnya: (h) memperoleh jaminan perlindungan keselamatan dan keamanan kepulangan TKI ke tempat asal; dan (i) memperoleh naskah perjanjian kerja yang asli. Sedangkan kewajiban setiap calon TKI/TKI antara lain: (a) mentaati peraturan perundangundangan baik di dalam negeri maupun di negara tujuan; (b) mentaati dan melaksanakan pekerjaannya sesuai dengan perjanjian kerja; (c) membayar biaya pelayanan penempatan TKI di luar negeri sesuai dengan peraturan perundang-undangan; dan (d) memberitahukan atau melaporkan kedatangan keberadaan dan kepulangan TKI kepada perwakilan Republik Indonesia di negara tujuan.

Pemenuhan hak-hak pekerja migran Indonesia dalam UU No. 39 Tahun 2004 tidak hanya dimaknai secara eksplisit sebagaimana dipaparkan di atas, tetapi peneliti lebih menitikberatkan pada aspek perlindungan TKI. Perlindungan TKI adalah segala upaya untuk melindungi kepentingan calon TKI/TKI dalam mewujudkan terjaminnya pemenuhan hak-haknya sesuai dengan peraturan perundang-undangan, baik sebelum, selama maupun sesudah bekerja. Dalam Pasal 77 UU No. 39/2004 ayat (1) menyatakan bahwa setiap calon TKI/TKI mempunyai hak 
untuk memperoleh perlindungan sesuai dengan peraturan perundang undangan. Sedangkan ayat (2) menyatakan bahwa perlindungan sebagaimana dimaksud pada ayat (1) dilaksanakan mulai dari pra penempatan, masa penempatan, sampai dengan purna penempatan.

Pemerintah menindaklanjuti Pasal 77 UU No. 39/2004 pada tahun 2013 mengesahkan Peraturan Pemerintah Republik Indonesia Nomor 3 Tahun 2013 tentang Perlindungan Tenaga Kerja Indonesia di Luar Negeri. Dalam Pasal 2 PP No. 3/2013 menyebutkan peraturan pemerintah ini mengatur mengenai: (a) perlindungan TKI mulai dari pra penempatan, masa penempatan sampai dengan purna penempatan; (b) perlindungan TKI melalui penghentian dan pelarangan penempatan TKI; dan (c) program pembinaan dan perlindungan TKI. Pasal 3 PP No. 3/2013 menegaskan bahwa perlindungan sebagaimana dimaksud dalam Pasal 2 diberikan kepada calon TKI/TKI yang ditempatkan oleh BNP2TKI, PPTKIS, perusahaan yang menempatkan TKI untuk kepentingan sendiri, dan TKI yang bekerja secara perseorangan. Kemudian pada Pasal 4 PP No. 3/2013 menyatakan bahwa pemerintah bersama pihak terkait dalam penempatan dan perlindungan TKI di luar negeri, wajib memberikan perlindungan secara penuh dan tanpa diskriminasi kepada calon TKI/TKI.

Perlindungan calon TKI pada masa pra-penempatan berdasarkan PP No. 3 Tahun 2013 meliputi: (1) perlindungan administratif dan (2) perlindungan teknis.

(1) Perlindungan administratif meliputi:

(a) pemenuhan dokumen penempatan meliputi: 
(a) Kartu Tanda Penduduk, ijazah pendidikan terakhir, akte kelahiran, atau surat keterangan kenal lahir;

(b) sertifikat kompetensi kerja;

(c) surat keterangan sehat berdasarkan hasil pemeriksaan psikologi dan pemeriksaan kesehatan;

(d) paspor yang diterbitkan oleh Kantor Imigrasi setempat;

(e) visa kerja;

(f) Kartu Tenaga Kerja Luar Negeri (KTKLN); dan

(g) dokumen lain yang dipersyaratkan sesuai dengan ketentuan peraturan perundang-undangan.

(b) penetapan biaya penempatan dilakukan berdasarkan:

a. negara tujuan penempatan; dan

b. sektor jabatan.

(c) penetapan kondisi dan syarat kerja meliputi jam kerja, upah dan tata cara pembayaran, hak cuti dan waktu istirahat, fasilitas, dan jaminan sosial.

(2) Perlindungan teknis meliputi:

(a) sosialisasi dan diseminasi informasi:

(1) dilakukan dalam bentuk penyuluhan dan kampanye peningkatan pemahaman cara bekerja di luar negeri.

(2) dilakukan secara langsung atau tidak langsung melalui media cetak dan/atau elektronik. 
(3) dilakukan oleh Pemerintah dan pemangku kepentingan terkait yang dikoordinasikan oleh instansi yang bertanggung jawab di bidang ketenagakerjaan.

(b) peningkatan kualitas calon TKI meliputi:

a. pelatihan;

b. uji kompetensi; dan

c. PAP (Pembekalan Akhir Pemberangkatan)

(c) pembelaan atas pemenuhan hak-hak TKI dilakukan dalam hal calon TKI meninggal dunia, sakit dan cacat, kecelakaan, gagal berangkat bukan karena kesalahan calon TKI, tindak kekerasan fisik dan pemerkosaan atau pelecehan seksual; dan (d) pembinaan dan pengawasan dilakukan terhadap pelaksana penempatan dan pihak terkait lainnya.

Perlindungan masa penempatan TKI di luar negeri berdasarkan PP No. 3 Tahun 2013 meliputi: (a) pembinaan dan pengawasan; (b) bantuan dan perlindungan kekonsuleran; (c) pemberian bantuan hukum; (d) pembelaan atas pemenuhan hak-hak TKI; dan (e) perlindungan dan bantuan lainnya sesuai dengan ketentuan peraturan perundang-undangan serta hukum dan kebiasaan internasional; dan (f) upaya diplomatik.

(a) pembinaan dan pengawasan meliputi:

a. pembinaan dan pengawasan terhadap TKI, perwakilan PPTKIS, mitra usaha, dan pengguna;

b. memberikan bimbingan dan advokasi kepada TKl; 
c. fasilitasi penyelesaian perselisihan atau sengketa TKI dengan pengguna dan/atau pelaksana penempatan $\mathrm{TKI}$;

d. menyusun dan mengumumkan daftar mitra usaha dan pengguna tidak bermasalah dan bermasalah secara berkala sesuai dengan ketentuan peraturan perundang-undangan; dan

e. melakukan kerja sama internasional dalam rangka perlindungan TKI sesuai dengan ketentuan peraturan perundang-undangan.

(b) bantuan dan perlindungan kekonsuleran;

a. pengurusan TKI sakit, kecelakaan, meninggal dunia;

b. akses komunikasi antara Perwakilan dan TKI; dan

c. akses informasi kepada negara penerima mengenai TKI yang mendapat masalah hukum.

(c) pemberian bantuan hukum meliputi:

a. pemberian mediasi;

b. pemberian advokasi;

c. pendampingan terhadap TKI yang menghadapi masalah hukum;

d. penanganan masalah TKI yang mengalami tindak kekerasan fisik dan pelecehan seksual; dan

e. penyediaan advokat/pengacara.

(d) pembelaan atas pemenuhan hak-hak TKI meliputi:

a. memanggil pihak yang tidak memenuhi hak-hak TKI; 
b. melaporkan kepada otoritas yang berwenang;

c. menuntut pemenuhan hak-hak TKl;

d. memperkarakan pihak yang tidak memenuhi hak-hak TKI;

e. bantuan terhadap TKI yang dipindahkan ke tempat lain/majikan lain yang tidak sesuai dengan perjanjian kerja;

f. penanganan terhadap TKI yang dipekerjakan tidak sesuai dengan perjanjian kerja; dan

g. penyelesaian tuntutan dan/atau perselisihan TKI dengan pengguna jasa TKI dan/atau mitra usaha.

Hak-hak TKI yang dibela meliputi hak-hak TKI yang diatur dalam perjanjian kerja, hukum nasional, hukum perburuhan setempat, dan konvensi internasional.

(e) perlindungan dan bantuan lainnya sesuai dengan ketentuan peraturan perundang-undangan serta hukum dan kebiasaan internasional, atau paling sedikit (a) menyediakan penerjemah bahasa; (b) pemulangan TKI; dan (c) pendekatan untuk mendapatkan pengampunan hukuman/pidana; dan

(f) upaya diplomatik dilakukan melalui saluran diplomatik dengan cara damai dan dapat diterima oleh kedua belah pihak sesuai dengan ketentuan peraturan perundang-undangan nasional serta hukum dan kebiasaan internasional. Upaya diplomatik ini dikoordinasikan oleh menteri yang bertanggung jawab di bidang hubungan luar negeri dan politik luar negeri. 
Perlindungan masa purna penempatan TKI berdasarkan PP No. 3 Tahun 2013 meliputi:

(a) pemberian kemudahan atau fasilitas kepulangan TKI;

(b) pemberian upaya perlindungan terhadap TKI dari kemungkinan adanya tindakan pihak-pihak lain yang tidak bertanggung jawab dan dapat merugikan TKI dalam kepulangan dari negara tujuan, di debarkasi, dan dalam perjalanan sampai ke daerah asal;

(c) fasilitasi pengurusan klaim asuransi;

(d) fasilitasi kepulangan TKI berupa pelayanan transportasi, jasa keuangan, dan jasa pengurusan barang;

(e) pemantauan kepulangan TKI sampai ke daerah asal;

(f) fasilitasi TKI bermasalah berupa fasilitasi hak-hak TKI; dan

(g) penanganan TKI sakit berupa fasilitasi perawatan kesehatan dan rehabilitasi fisik dan mental.

UU No. 29/1999 tentang HAM di awal pembahasan menyatakan bahwa pemerintah diminta menghormati, melindungi, menegakkan, dan memajukan hak asasi manusia baik yang diatur dalam undang-undang maupun hukum internasional. Penempatan dan perlindungan calon TKI/TKI dalam UU No. 39/2004 bertujuan untuk: (a) memberdayakan dan mendayagunakan tenaga kerja secara optimal dan manusiawi; (b) menjamin dan melindungi calon TKI/TKI sejak di dalam negeri, di negara tujuan, sampai kembali ke tempat asal di Indonesia; dan (c) meningkatkan kesejahteraan TKI dan keluarganya. 
Di samping itu, hukum internasional dapat digunakan dalam konteks pemajuan perlindungan TKI. Bustamante (2002) dalam Pranoto (2011:6) menyatakan bahwa keadaan ini tidak bisa dilepaskan dari faktafakta yang menunjukkan akan pemberian hak khusus bagi para pekerja migrant di mata masyarakat internasional. Dalam kaitannya dengan itu, Antoine Pécoud dan Paul deGuchteneire memandang stagnasi yang ada lebih disebabkan karena ketidaan kehendak politik semata. Oleh karenanya sangatlah tepat apabila kita hendak memajukan perlindungan hukum bagi pekerja migran untuk mulai secara serius mempertimbangkan pemanfaatan terhadap hukum internasional. ${ }^{54}$

Pranoto (2011:7-8) menyatakan ia mendorong semua pihak untuk secara serius mempertimbangkan pemanfaatan hukum HAM internasional bagi pemajuan HAM, khususnya bagi pekerja migran Indonesia (atau yang lebih dikenal sebagai Tenaga Kerja Indonesia atau TKI) dan penciptaan sebuah manajemen migrasi yang baik. Usulan ini tidak bisa dilepaskan dari fakta yang menunjukkan bahwa baik pemerintah Indonesia maupun para pihak yang terlibat dalam advokasinya belum mampu memanfaatkannya secara maksimal. Hal yang terjadi justru sebaliknya, mereka cenderung menaruh curiga yang berlebih-lebihan terhadap hukum internasional. Padahal pemanfaatan hukum internasional oleh para advokat HAM pekerja migran di negara-negara lain telah menjadi pilihan utama dalam perjuangannya. Padahal secara legal-formal pemanfaatan mekanisme hukum internasional telah diakui sebagai HAM

\footnotetext{
${ }^{54}$ Pranoto Iskandar (ed.), (2011), Standar Internasional Migrasi Ketenagakerjaan Berbasis HAM, Cianjur: IMR Press, h. 6.
} 
oleh hukum nasional. Dengan kata lain, diabaikannya pemanfaatan mekanisme internasional yang seakan dilakukan secara sistematis bisa disamakan sebagai pelanggaran HAM serius. ${ }^{55}$ Ismantoro (2011:167-168) juga menyatakan bahwa pemerintah Indonesia dalam melakukan pembaruan hukum tentang TKI juga harus berpedoman dengan hukum internasional, yakni nilai-nilai konvensi internasional yang berkaitan dengan perlindungan terhadap buruh migran dan keluarganya. ${ }^{56}$

Pranoto (2011:43) menyatakan standar yang paling komprehensif bagi praktek migrasi di tingkat lokal dan internasional dapat dirujuk Convention of Migrant Workers (CMW). Nilai penting CMW tidak bisa dilepaskan dari 7 fitur yang dikandungnya: (1) langkah awal bagi perlindungan HAM dasar; (2) menawarkan pendekatan HAM dalam isu pekerja migran; (3) mengangkat situasi buruk yang dihadapi oleh sebagian pekerja migran; (4) bersifat komprehensif mulai dari pembahasan sampai pemulangan; (5) pengakuan secara tegas akan HAM para migran tanpa mempertimbangkan status migrasinya; (6) memuat pengertian-pengertian yang telah diakui secara internasional; dan (7) memiliki komite khusus yang ditujukan untuk menangani isu pekerja migran. $^{57}$

Hukum substantif bagi perlindungan pekerja migran dalam hukum internasional menurut Pranoto (2011:44) perlu memperhatikan prinsip dasar dalam sistem perlindungan internasional bagi pekerja migran di

\footnotetext{
55 Ibid. hh. 7-8.

56 Ismantoro Dwi Yuwono, (2011), Hak dan Kewajiban Tenaga Kerja Indonesia di Luar Negeri, Yogyakarta: Penerbit Pustaka Yustisia, hh. 167-168.

57 Pranoto Iskandar (ed.), op.cit. h. 43.
} 
mana negara dimungkinkan untuk menolak memberikan pekerjaan kepada bukan warga negaranya, tetapi "ketika hubungan kerja telah tercipta, maka semua orang berhak atas hak-hak perburuhan dan kepegawaian". Berikut adalah daftar hak-hak yang dimiliki oleh para pekerja migran sesuai dengan hukum internasional. ${ }^{58}$

Hak-Hak Dasar meliputi:

1) Perlindungan yang sama di depan hukum dan tidak ada pembatasan terhadap kebanyakan hak-hak sipil dan politik tanpa mempertimbangkan "status lainnya", termasuk status tak berdokumen;

2) Kewajiban untuk menghormati dan menjalankan HAM tanpa... status keimigrasian seseorang;

3) Hak atas "upaya hukum efektif" bagi pelanggaran-pelanggaran HAM dan atas "perimbangan secara adil oleh sebuah peradilan yang kompeten, independen dan imparsial ... untuk menentukan hak-hak dan kewajiban-kewajiban $\ldots$ terkait dengan hakikat kesipilannya [atau] pekerjaan;

4) Pelarangan atas kerja paksa;

5) Gaji yang sepadan dengan pekerjaan dan bayaran yang setara dengan kerja "tanpa dibeda-bedakan";

6) Kebebasan untuk berkelompok, berserikat dan menegosiasikan hak, termasuk memperoleh upaya hukum atas pelanggarannya;

7) Lembur dan sebuah hari kerja dengan waktu yang masuk akal;

58 Ibid. h. 44. 
8) Hari libur periodik dengan bayaran;

9) Kondisi kerja yang layak, termasuk perlindungan atas keselamatan dan kesehatan;

10)Kompensasi bagi para pekerja migrant dan perlindungan kesehatan bagi para pekerja migran yang mengalami kecelakaan;

11)Perbaikan atas segala aspek kebersihan industrial dan pencegahan atas penyakit akibat pekerjaan;

12)Tersedianya "jaminan judicial dan administratif" dan upaya hukum yang efektif bagi segala pelanggaran yang terjadi;

13)Keikutsertaan dalam skema jaminan sosial atau hak untuk mendapat kontribusi jaminan sosial;

14)Kewajiban negara penerima untuk mengambil langkah "pencegahan dan perbaikan atas persoalan serius akibat ... belitan hutang";

15)Kewajiban negara penerima untuk melakukan tindakan-tindakan khusus "untuk mencegah dan memperbaiki persoalan serius terkait dengan ... penahanan paspor";

16) Kewajiban negara penerima untuk mengambil langkah-langkah khusus "untuk mencegah dan memperbaiki persoalan serius terkait dengan ... penahanan ilegal oleh majikan atau pemberi kerja; 
17)Kewajiban negara penerima untuk mengambil langkah-langkah khusus "untuk mencegah dan memperbaiki persoalan serius terkait ... pemerkosaan dan penyerangan fisik";

18)Kewajiban negara penerima untuk mencegah diskriminasi dalam rangka bekerja;

19)Bagi korban penjualan manusia "layanan konseling dan informasi", khususnya terkait dengan hak-haknya dalam bahasa yang dimengerti dan ... kesempatan untuk memperoleh pelatihan, pendidikan dan pekerjaan;

20)Bagi korban penjualan manusia, status hukum keimigrasiannya didasarkan pada traum yang mereka derita dan padaa saat pemulangannya dituntut kerjasama dengan pejabat penegak hukum untuk penanganan atas kejahatan yang mana ia merupakan korbannya. ${ }^{59}$

Hak-Hak Tambahan bagi Pekerja Migran Berdokumen meliputi:

1) Kewenangan untuk memilih/merubah pekerjaan tanpa kehilangan statusnya (kurang dinyatakan secara tegas);

2) Tidak kehilangan status dan izin kerja hanya dikarenakan kehilangan pekerjaan;

3) Hak untuk bekerja bagi para anggota keluarganya (dinyatakan secara tidak tegas);

4) Unifikasi keluarga (dinyatakan secara tidak tegas);

59 Ibid. hh. 44-48. 
5) Asuransi pengangguran (didasarkan pada pertimbangan nasionalitas) dan "skema kerja publik" (didasarkan pada pertimbangan nasionalitas). ${ }^{60}$

Selain hak-hak yang telah dipaparkan di atas, hukum internasional yang menetapkan standar-standar yang menciptakan suatu model bagi hukum-hukum serta prosedur administrasi dan peradilan masing-masing negara diatur dalam Konvensi Internasional Perlindungan Hak-Hak Pekerja Migran (International Convention of the Protection of the Rights of All Migrant Workers and Members of their Families). Setiap negara yang meratifikasi konvensi ini dikenai kewajiban untuk menetapkan langkahlangkah guna menjamin bahwa pekerja migran dilindungi hak-haknya dan dapat mencari upaya penyelesaian bila hak tersebut dilanggar. Indonesia menjadi negara pihak Konvensi ini setelah melalui proses panjang yakni penandatanganan pada 22 September 2004, pembahasan di Dewan Perwakilan Rakyat (DPR) Republik Indonesia pada 9 dan 12 April 2012. Konvensi ini ditandatangani oleh Presiden Susilo Bambang Yudhoyono pada 2 Mei 2012 menjadi UU No. 6 Tahun 2012 tentang pengesahan International Convention on the Protection of The Rights Of All Migrant Workers and Members of Their Families (Konvensi Internasional mengenai Perlindungan Hak-Hak Seluruh Pekerja Migran dan Anggota Keluarganya). Perserikatan Bangsa-Bangsa (PBB) menerima dokumen hasil ratifikasi Indonesia pada 31 Mei 2012.

60 Ibid. h. 49. 
Ketentuan konvensi ini berlaku selama seluruh proses pekerja migran dan anggota keluarganya, yang terdiri dari persiapan untuk migrasi, pemberangkatan, transit dan seluruh masa tinggal dan pekerjaan yang dibayar di dalam negara tempat bekerja dan juga kembalinya ke negara asal atau negara tempatnya bertempat tinggal. Dan negara asal, negara tempat bekerja atau negara transit berkewajiban memberitahukan hak-hak yang muncul dari konvensi ini kepada pekerja migran dan anggota keluarganya, baik kondisi pemeriksaan mereka, hak dan kewajiban pekerja migran menurut hukum dan praktek negara yang bersangkutan. Dalam ketentuan konvensi ini telah diatur tentang jenis, macam dan bentuk-bentuk hak buruh migran antara lain:

1) Hak anti diskriminasi, hak ini berkaitan dengan hak buruh migran guna memperoleh hak yang diatur dalam konvensi ini tanpa diskriminasi, baik jenis kelamin, ras, warna kulit, bahasa, agama, kepercayaan, etnis dan lain-lain;

2) Hak hidup;

3) Hak bebas dari kekerasan, penyiksaan dan perlakuan tidak manusiawi lainnya;

4) Kebebasan untuk berpikir, keyakinan dan beragama;

5) Hak berpendapat;

6) Hak untuk bebas bekerja;

7) Hak keamanan pribadi dan privasi serta berkomunikasi dengan orang lain;

8) Perlindungan yang baik dalam proses kerja; 
9) Hak atas perawatan kesehatan;

10)Hak atas pendidikan berdasarkan persamaan perlakuan dengan warga negara dari negara yang bersangkutan;

11)Hak untuk berlibur;

12)dan lain sebagainya. ${ }^{61}$

Hak-hak yang tercantum dalam ketentuan Konvensi Internasional tentang Perlindungan atas Hak Pekerja Migran dan Anggota Keluarganya ini terdapat dalam 3 klasifikasi yaitu:

1. Hak buruh migran sebagai pekerja, yaitu:

a. Hak untuk bekerja;

b. Hak untuk diakui secara hukum sebagai pekerja;

c. Hak atas kondisi kerja yang layak;

d. Hak atas rasa aman dan kondisi kerja yang aman;

e. Hak untuk memiliki dan memelihara kehidupan pribadi;

f. Hak untuk berorganisasi dan berserikat;

g. Hak untuk bebas dari kerja paksa dan perbudakan.

2. Hak buruh migran sebagai warga, yaitu bahwa buruh migran adalah sekaligus warga komunitas asalnya, warga negara dan warga dunia, sehingga mereka berhak diakui potensinya untuk berkontribusi terhadap kehidupan bermasyarakat di negara asing tempatnya bekerja.

3. Hak buruh migran sebagai perempuan. Hak ini didasarkan pada kondisi perempuan yang rentan terhadap kekerasan termasuk

${ }^{61}$ Ismantoro Dwi Yuwono, op.cit., hh. 118-119. 
jati dirinya. Konteks Indonesia hak ini juga sangat penting karena mayoritas buruh migran adalah perempuan, antara lain: hak atas integritas jiwa dan raga, khususnya untuk bebas dari segala bentuk kekerasan fisik, psikis dan seksual, hak untuk bebas dari diskriminasi berbasis gender, hak atas senksualitas dan kesehatan reproduksi, termasuk pengetahuan tentang hal ini dan akses termasuk pengetahuan tentang hal ini dan akses pada layanan kesehatan yang bermutu, hak untuk mendapatkan pemberdayaan dan pendampingan sebagai perempuan. ${ }^{62}$

Dalam konvensi internasional ini diatur secara tegas mengenai aspek dari kewajiban negara, baik negara asal maupun negara tempat buruh migran bekerja. Kewajiban-kewajiban tersebut adalah sebagai berikut:

1. Kewajiban untuk memberikan perlindungan efektif terhadap kekerasan fisik, kerugian fisik, ancaman dan intimidasi, baik yang dilakukan oleh pejabat publik maupun perorangan, kelompok maupun lembaga termasuk verifikasi oleh petugas penegak hukum harus dilakukan sesuai dengan prosedur hukum yang berlaku;

2. Negara wajib memberitahukan setiap penangkapan terhadap buruh migran dan anggota keluarganya, termasuk alasannya, serta tuduhan yang diajukan dengan menggunakan bahasa yang dimengerti oleh mereka;

62 Ibid. hh. 119-120. 
3. Kewajiban memberitahukan setiap penangkapan, penahanan, selama menunggu untuk diadili dan penahanan dalam bentuk lainnya, kepada konsuler atau pejabat diplomatik negara asalnya apabila yang bersangkutan memintanya;

4. Kewajiban memberitahukan hak-hak dan kesempatan kepada buruh yang ditahan untuk berkomunikasi dengan pejabatpejabat tertentu;

5. Negara harus memberitahukan hak-haknya berdasarkan perjanjian internasional lain yang berlaku antara negara-negara yang bersangkutan untuk berkorespondensi dan bertemu dengan pejabat tersebut di atas, dan mengatur advokat dengan mereka;

6. Kewajiban untuk melaksanakan peradilan guna menentukan keabsahan penahanan dan memerintahkan pembebasan apabila penahanan tersebut ternyata tidak sah menurut hukum. Negara wajib memberikan ganti kerugian terhadap penahanan yang dilakukan secara melawan hukum;

7. Kewajiban untuk menyediakan bantuan hukum, penerjemah, jika perlu tanpa membayar;

8. Kewajiban untuk melakukan tindakan yang manusiawi, menghormati martabat yang melekat pada diri manusia dan identitas budaya terhadap buruh migrant dan anggota keluarganya yang ditahan; 
9. Kewajiban negara untuk memisahkan dari orang yang dipidana terhadap buruh migran dan anggota keluarganya yang dikenakan tuduhan. Terdakwa di bawah umur harus dipisahkan dari orang dewasa, dan segera mungkin dihadapkan ke siding pengadilan;

10. Kewajiban negara untuk memisahkan dari orang yang dipidana atau tengah menunggu persidangan terhadap buruh migran dan anggota keluarganya yang ditahan karena melanggar ketentuan migrasi;

11. Negara harus menjamin bahwa perbuatan seseorang yang menghancurkan atau mencoba menghancurkan dokumen identitas, dokumen yang memberikan ijin masuk atau keluar, tempat kediaman, atau tempat tinggal dalam wilayah nasional, atau ijin kerja merupakan perubahan melawan hukum;

12. Negara tempat bekerja yang melakukan pengusiran tidak boleh mengurangi hak apapun yang telah diperoleh buruh migran dan anggota keluarganya sesuai dengan hukum negara tersebut, termasuk hak untuk menerima upah/gaji dan hal lain yang menjadi haknya;

13. Negara harus melindungi hak-hak buruh migran dan memastikan hak-hak tersebut dijalankan oleh majikan dengan perjanjian kerja. $^{63}$

${ }^{63}$ Ibid. hh. 121-123. 
Konvensi ini juga membagi kategori hak-hak buruh migran/TKI menjadi dua yakni hak asasi untuk buruh migran dan keluarganya secara umum dan hak buruh. Berikut daftar hak buruh migrant dalam Konvensi yang dikutip dari kertas kerja Human Rights Working Group (2010) berjudul "Ratifikasi Konvensi Perlindungan Hak Semua Buruh Migran dan Anggota Keluarganya! Belajar dari Meksiko". Hak yang dijamin bagi semua buruh migran dan keluarganya, di antara hak-hak tersebut adalah:

1. Bebas keluar masuk dari negara asal. Hak ini tidak boleh dibatasi kecuali pada kasus-kasus yang:

a. Ditentukan oleh Undang-Undang;

b. Dipandang perlu untuk melindungi keselamatan bangsa, keteraturan masyarakat, kesehatan masyarakat dan moral atau hak dan kebebasan orang lain;

c. Konsisten dengan hak-hak lain yang diakui dalam bagian Konvensi yang masih berlaku (Pasal 8).

2. Hak atas kehidupan yang dilindungi oleh hukum (Pasal 9);

3. Hak untuk tidak menjadi korban penyiksaan atau bentuk-bentuk tindakan atau hukuman yang kejam, tidak manusiawi dan merendahkan (Pasal 10);

4. Bebas dari perbudakan atau memberikan pelayanan kerja paksa, termasuk kerja dalam tahanan (Pasal 11);

5. Hak untuk bebas berpikir, memiliki keyakinan dan berpendapat (Pasal 12); 
6. Hak untuk memiliki pendapat yang bebas dari intervensi bebas berekspresi termasuk bebas untuk mencari, menerima dan berbagai informasi (Pasal 13);

7. Bebas dari bentuk intervensi sewenang-wenang maupun di luar hukum terhadap privasi yang bersangkutan (Pasal 14);

8. Hak untuk memiliki properti/barang-barang dan bebas dari perampasan harta yang sewenang-wenang (Pasal 15);

9. Hak kebebasan atau keselamatan individu (Pasal 16);

10. Hak atas proses hukum yang sesuai dengan Undang-Undang dalam kasus-kasus terjadinya tindakan kejahatan (Pasal 17 dan 18);

11. Tidak ada penyitaan atau penghancuran terhadap dokumen identitas, atau dokumen izin masuk atau izin tinggal atau izin kerja (Pasal 19);

12. Tidak ada pemecatan/dipulangkan secara kolektif. Setiap kasus pemecatan akan dikaji dan diputuskan secara individual, kecual diputuskan oleh pejabat yang kompeten, sesuai dengan Undang-Undang (Pasal 21) dan pembiayaan pemulangan (Pasal 22);

13. Hak untuk meminta perlindungan dan bantuan dari konsuler atau perwakilan diplomatik Negara yang bersangkutan (Pasal 23);

14. Hak untuk memperoleh pengakuan sebagai individu di depan hukum (Pasal 24); 
15. Hak untuk memperoleh perlakuan yang adil sesuai kewarganegaraan terkait dengan penghasilan (Pasal 25);

16. Bebas berasosasi atau memiliki hak untuk bergabung dengan serikat pekerja (Pasal 26);

17. Hak untuk memperoleh jaminan sosial; sesuai dengan kewarganegaraannya jika memenuhi persyaratan (Pasal 27);

18. Hak untuk memperoleh pelayanan kesehatan (Pasal 28);

19. Penghormatan atas identitas budaya pekerja migran dan anggota keluarga mereka (Pasal 29);

20. Hak untuk memindahkan pendapatan atau simpanan mereka, barang-barang milik pribadi, saat berakhirnya izin tinggal, sesuai dengan Undang-Undang yang berada dalam Negara terkait (Pasal 30-32);

21. Hak untuk diberitahukan mengenai hak-hak mereka berdasarkan Perjanjian, persyaratan izin masuk, serta hak-hak dan kewajiban mereka berdasarkan Undang-Undang dari Negara penerima (Pasal 33).

Kebijakan/hukum di tingkat nasional dan internasional telah dipaparkan di atas. Ketentuan-ketentuan tersebut akan menjadi acuan bagi peneliti untuk menyusun indikator pemenuhan hak-hak pekerja migran (Indonesia) asal Sulawesi Selatan, utamanya kebijakan yang berlaku nasional dikarenakan kebijakan tersebut merupakan representasi pemerintah terhadap penanganan persoalan yang dihadapi oleh warga negaranya (TKI). Walau demikian, kebijakan di negara tujuan yakni 
Malaysia tetap akan menjadi bahan pertimbangan untuk mengkonfirmasi apakah hak-hak yang tercantum dalam hukum internasional dipatuhi oleh negara tujuan kerja atau tidak.

\subsection{Hasil Penelitian yang Relevan}

Penelitian yang relevan dengan penelitian ini yakni, penelitian mengenai Hak Asasi Manusia, khususnya hak-hak pekerja migran maupun hubungan Indonesia-Malaysia di bidang ketenagakerjaan.

Penelitian Pelanggaran Malaysia terhadap Standar Hak Asasi Manusia (HAM) CEDAW dalam Isu Kekerasan Migrant Domestic Worker Indonesia merupakan penelitian dari Kardina. Penelitian ini mengkaji kepatuhan Malaysia terhadap standar HAM Internasional CEDAW dan penyebab kekerasan terhadap pekerja migran (MDW) Indonesia di Malaysia. Penelitian ini menemukan bahwa penyebab kekerasan terhadap pekerja migran (MDW) Indonesia berasal dari persepsi ancaman yang diterapkan oleh pemerintah Malaysia kepada migran ilegal yang mempengaruhi kapabilitas aktor elit domestik untuk membangun mekanisme enforcement perlindungan yang sesuai dengan prinsip CEDAW. Sehingga, kebijakan Malaysia dalam menangani masalah pekerja migran Indonesia (MDW) masih mengandung unsur diskriminasi terhadap perlindungan HAM yang merupakan pelanggaran prinsip konvensi. $^{64}$

${ }^{64}$ Kardina, (2015), Pelanggaran Malaysia terhadap Standar HAM Convention on the Elimination of All Forms of Discrimination Against Women dalam Isu Kekerasan Migrant Domestic Worker Indonesia, Tesis, Universitas Gadjah Mada. 
Penelitian mengenai pemenuhan hak-hak pekerja migran Indonesia, dikaji Faizah Khotimatul Husna dalam penelitian yang berjudul Kajian Kebijakan Pemerintah dalam Penempatan dan Perlindungan Tenaga Kerja Indonesia. Penelitian ini bertujuan untuk mengetahui isi regulasi yang ada dalam merespon permasalahan tentang Tenaga Kerja Indonesia, serta untuk mengetahui pembagian tugas dan kewenangan lembaga pelaksana penanganan TKI. Hasil penelitian ini menunjukkan bahwa sebagian permasalahan penempatan TKI yang terjadi disebabkan oleh regulasi yang kurang, yaitu belum adanya regulasi yang mengatur secara spesifik, padahal dalam peraturan perundang-undangan yang lebih tinggi telah mengamanatkan hal tersebut. Misalnya dalam hal sosialisasi penempatan TKI kepada masyarakat luas, dan dalan dalam hal bantuan hukum kepada TKI yang terkena masalah hukum. Di samping itu terdapat dua tugas dan kewenangan pemerintah kabupaten/kota dalam hal pelaksanaan rekrutmen yang semestinya tidak dapat dijalankan sekaligus, yaitu sebagai pelaksana rekrutmen dan pengawas. ${ }^{65}$

Penelitian mengenai Analisis Masalah Sosial, Politik dan Ekonomi pada Migrasi Tenaga Kerja Indonesia ke Luar Negeri dilaksanakan oleh tim peneliti Indah Susilowati, Mudji Rahardjo dan Waridin. Secara umum, kajian ini menganalisis masalah sosial, politik dan ekonomi pada migrasi TKI ke luar negeri. Secara khusus penelitian ini mengkaji faktor-faktor yang mempengaruhi niat TKI bermigrasi secara permanen ke luar negeri, mengetahui faktor-faktor yang mendorong calon TKI untuk bermigrasi ke

\footnotetext{
65 Faizah Khotimatul Husna, (2013), Kajian Kebijakan Pemerintah dalam Penempatan
} dan Perlindungan Tenaga Kerja Indonesia, Tesis, Universitas Gadjah Mada. 
luar negeri, mencari solusi dari masalah-masalah yang sering dihadapi TKI atau calon TKI dan memberikan rekomendasi kepada pihak-pihak terkait. $^{66}$

Hasil penelitian ini menunjukkan bahwa sebagian besar calon TKI belum berpengalaman bekerja di luar negeri. Faktor harapan untuk mencari pekerjaan lebih baik merupakan faktor dominan yang menyebabkan TKI bermigrasi ke luar negeri. TKI bermigrasi dan bekerja ke luar negeri karena kesempatan kerja dengan hasil yang sesuai tidak banyak tersedia di dalam negeri. Dengan demikian faktor ekonomi merupakan determinan utama bagi calon TKI/migran kembali dan TKI untuk bermigrasi ke luar negeri. Sedangkan faktor non-ekonomi seperti mencari pengalaman kerja di luar negeri dan mencari kepuasan menempati urutan yang lebih rendah. Dijumpai cukup banyak TKI yang belum memiliki keterampilan dan pengetahuan yang memadai. Akibat kondisi yang demikian banyak di antara mereka yang menghadapi masalah di negara tujuan, baik dalam hubungan mereka dengan pihak majikan maupun dengan pihak pemerintah di negara tujuan, khususnya yang menyangkut pemenuhan aturan-aturan perundangan yang berlaku. ${ }^{67}$

Hasil estimasi yang dilakukan dengan menggunakan model Logit Binary dapat diketahui bahwa empat faktor yang dapat mempengaruhi niat responden untuk bermigrasi (dan bekerja) secara permanen di negara tujuan. Faktor-faktor tersebut adalah: status perkawinan dan lama tinggal

\footnotetext{
${ }^{66}$ Indah Susilowati, Mudji Rahardjo dan Waridin, (2001), Analisis Masalah Sosial, Politik dan Ekonomi pada Migrasi Tenaga Kerja Indonesia ke Luar Negeri, Laporan Penelitian DCRG, Universitas Diponegoro. ${ }^{67}$ Ibid.
} 
di negara tujuan (keduanya termasuk faktor sosial), pendapatan yang diperoleh di negara tujuan (faktor ekonomi), serta pengalaman kerja di luar negeri yang ditunjukkan dari banyaknya kepulangan TKI ke daerah asal setelah bekerja di luar negeri. Sedangkan faktor-faktor lainnya yang diduga mempengaruhi niat TKI melakukan migrasi/bekerja di luar negeri, secara statistik tidak dapat menjelaskan fenomena dari niat untuk menetap secara permanen di negara tujuan migrasi. Apabila diurutkan menurut tingkat signifikansi statistiknya, maka faktor penentu utama yang dapat mempengaruhi niat TKI bekerja di luar negeri adalah pengalaman bekerja di luar negeri, diikuti besarnya pendapatan, status perkawinan dan lama tinggal di negara tujuan. Hasil analisis dari model Logit Multinominal menunjukkan TKI yang berumur muda, berpendidikan rendah, tidak sering pergi-pulang dan berasal dari daerah subur cenderung tidak berniat untuk menetap di negara tujuan. ${ }^{68}$

Penelitian tentang kebijakan pemerintah Indonesia terhadap TKI diteliti oleh Desi Auliani Hasibuan dengan judul: Kebijakan Politik Pemerintah Susilo Bambang Yudhoyono Mengenai Hak Asasi Manusia (HAM) Tahun 2004-2009 (Studi Analisis Mengenai TKI yang Bekerja di Malaysia). Penelitian ini mengkaji kebijakan politik SBY mengenai Hak Asasi Manusia terhadap tenaga kerja Indonesia yang bekerja di Malaysia, serta memahami apakah kebijakan ini terealisasi atau tidak. Hasil penelitian ini menunjukkan terjadinya pergeseran struktur ekonomi yang disusul dengan perubahan komposisi tenaga kerja. Pergeseran struktur

${ }^{68}$ Ibid. 
ekonomi maupun perubahan komposisi tenaga kerja ini berimplikasi terhadap proses pergeseran nilai. Kebijakan (politik) pemerintah diarahkan untuk memberdayakan dan mendorong kapasitas tenaga kerja yang mampu diandalkan secara pengetahuan dan keterampilan. Hal ini sangat berkaitan dengan kemampuan pemerintah dalam menyusun rencanarencana dan kebijakan yang lebih berpihak pada publik, terutama tenaga kerja Indonesia. $^{69}$

Penelitian Analisis Kebijakan Susilo Bambang Yudhoyono dalam Menangani Masalah Tenaga Kerja Indonesia di Malaysia dalam Perspektif Ekonomi Politik diteliti oleh Aspiannor Masrie. Penelitian ini mengkaji peluang dan tantangan hubungan bilateral Indonesia-Malaysia di bidang ketenagakerjaan di era kedua pemerintahan Susilo Bambang Yudhoyono (2009-2014), dan kajian mengenai strategi kebijakan ekonomi politik yang diterapkan pemerintahan Susilo Bambang Yudhoyono (SBY) dalam menangani berbagai kasus tenaga kerja Indonesia di Malaysia. Hasil penelitian menunjukkan bahwa permasalahan TKI di Malaysia sangat kompleks dan melibatkan berbagai elemen yang saling terkait. Di masa pemerintahan Susilo Bambang Yudhoyono (SBY), secara politik, persoalan TKI belum banyak mengalami perubahan sebagaimana kasus yang dialami Winfaidah, wanita asal Lampung yang menjadi korban penyiksaan majikannya di Penang dan Nurul Aidah yang ditemukan tewas dalam bagasi mobil majikannya. Secara ekonomi, keberadaan TKI memberikan sumbangsih yang cukup signifikan terhadap perekonomian

${ }^{69}$ Desi Auliani Hasibuan, (2011), Kebijakan Politik Pemerintah Susilo Bambang Yudhoyono Mengenai Hak Asasi Manusia (HAM) Tahun 2004-2009 (Studi Analisis Mengenai TKI yang Bekerja di Malaysia), Skripsi, Universitas Sumatera Utara. 
dalam negeri dengan pemasukan devisa yang dihasilkan dari remitansi yang dikirimkan TKI, bisa mencapai Rp. 60 triliun (US\$ 6,615 miliar) setiap tahunnya. Sedangkan strategi yang diterapkan SBY, melalui strategi politik dan ekonomi dengan pendekatan ekonomi politik. ${ }^{70}$

Penelitian dari Faridah Jaafar terkait Kebijakan terhadap Pekerja Asing: Tantangan dalam Hubungan Indonesia-Malaysia merupakan hal terkait lainnya. Penelitian ini mengkaji dua sisi pemerintah yakni Malaysia dan Indonesia. Penelitian ini menyimpulkan permasalahan pekerja migran Indonesia di Malaysia tidak akan pernah selesai, jika permasalahan ini tidak diselesaikan oleh kedua pihak, maka kedua negara harus mencari perspektif yang sama untuk mengurangi perbedaan dan bekerja dalam kerangka mutual understanding. ${ }^{71}$

Penelitian mengenai kondisi Pekerja Migran Indonesia di Malaysia juga dikaji oleh Amarjit Kaur. Penelitian ini mengevaluasi migrasi pekerja Indonesia ke Malaysia dari perspektif sejarah dan kontemporer yang difokuskan pada tujuan migrasi dan dinamika kebijakan perbatasan. Penelitian ini juga mengkaji secara meluas gap ekonomi, sosial dan demografis antara dua negara dan membahas secara garis besar arus

\footnotetext{
70 Aspiannor Masrie, (2015), Analisis Kebijakan Susilo Bambang Yudhoyono dalam Menangani Masalah Tenaga Kerja Indonesia di Malaysia dalam Perspektif Ekonomi Politik, Tesis, Universitas Hasanuddin.

${ }^{71}$ Faridah Jaafar, (2015), Foreign Workers Policies: Challenges in Malaysia-Indonesia Relations dalam Muhammad Nasir Badu (ed.), Proceeding of International Seminar Democracy and Election: Solution for Establishing Good Governance, Yogyakarta: LeutikaBooks.
} 
migrasi, pola rekrutmen, praktek kebijakan negara dan pertumbuhan migrasi ilegal ke Malaysia. $^{72}$

Penelitian tentang kondisi pekerja migran Indonesia di Malaysia dari perspektif peneliti Indonesia dilakukan oleh Nur Angga Ardiyanto dengan judul: Kajian Migrasi dan Penghidupan Tenaga Kerja asal Indonesia di Kampung Pandan dalam Ampang Jaya Malaysia. Penelitian ini dilatarbelakangi permasalahan legalitas yang merupakan hal yang fundamental dalam kajian migrasi internasional yang menitikberatkan pada migrasi tenaga kerja berkeahlian rendah dari Indonesia, tetapi pekerja migran Indonesia memiliki pemahaman yang kurang terkait birokrasi dalam pengurusan izin kerja. Penelitian ini mengkaji tentang faktor penarik dan pendorong yang mempengaruhi motivasi tenaga kerja asal Indonesia untuk bekerja di Malaysia dan mengkaji peranan kepemilikan aset di daerah asal terhadap status legalitas migrasi, serta mengidentifikasi pengaruh legalitas terhadap keberhasilan migrasi yang diukur melalui indikator besaran upah yang diterima setiap bulannya dan yang dikirimkan ke daerah asalnya. Hasil penelitian ini menunjukkan bahwa status legalitas turut memegang peranan dalam keberhasilan migrasi yang dinilai melalui indikator upah dan uang kiriman setiap bulannya. Sedangkan status legalitas dipengaruhi oleh kepemilikan aset di

\footnotetext{
${ }^{72}$ Amarjit Kaur, (2005), Indonesian migrant workers in Malaysia: from preferred migrants to 'last to be hired' workers dalam Jurnal Review of Indonesian and Malaysian Affairs, Vol. 39 No. 2 (2005), hh. 3-30.
} 
daerah asal tenaga kerja dan juga proses yang terjadi selama migrasinya. $^{73}$

Jika dibandingkan dengan penelitian yang telah dilakukan sebelumnya, maka penelitian tentang analisis ekonomi politik pemenuhan hak-hak pekerja migran asal Sulawesi Selatan di Malaysia merupakan penelitian yang memiliki nilai kebaruan (novelty) dari sisi pendekatan. Pendekatan yang digunakan dalam penelitian ini menggunakan analisis ekonomi politik, secara spesifik ekonomi politik kelembagaan. Di samping itu, lokasi penelitian yang lebih spesifik ke Sulawesi Selatan (Sulsel). Penelusuran yang dilakukan oleh peneliti, belum menemukan penelitian tentang pekerja migran yang spesifik pada provinsi Sulsel, diharapkan melalui penelitian ini maka potensi yang dimiliki oleh Sulsel dapat tergali dan juga menjadi bahan masukan bagi pemerintah daerah.

\subsection{Kerangka Pemikiran}

Pekerja Migran Indonesia dan Warga Negara Indonesia merupakan objek yang sama. Apabila kita membicarakan hak warga negara Indonesia untuk memperoleh pekerjaan, maka hak itu juga melekat pada pekerja migran. Penempatan PMI/TKI di luar negeri merupakan alternatif solusi untuk mengatasi pengangguran di Indonesia, karena pemerintah belum dapat memenuhi lapangan kerja di dalam negeri, sehingga PMI/TKI melakukan migrasi kerja ke berbagai negara di dunia.

\footnotetext{
${ }^{73}$ Nur Angga Ardiyanto, (2013), Kajian Migrasi dan Penghidupan Tenaga Kerja asal Indonesia di Kampung Pandan dalam Ampang Jaya Malaysia, Skripsi, Universitas Gadjah Mada.
} 
Malaysia merupakan negara tujuan utama bagi Pekerja Migran asal Sulawesi Selatan. Data BP3TKI Makassar menyatakan 90 persen penempatan pekerja migran asal Sulawesi Selatan selama empat tahun terakhir (2012-2015) ditujukan ke Malaysia. Hal ini semakin dikuatkan data Kedutaan Besar Republik Indonesia (KBRI) di Kuala Lumpur, Malaysia menyebutkan 1.306.756 jiwa dari 2.591.447 WNI di Malaysia atau sebesar $50,42 \%$ berstatus TKI/PMI yang bekerja di berbagai sektor. Hal ini menunjukkan Malaysia merupakan negara tujuan TKI/PMI asal Sulawesi Selatan dengan jumlah yang signifikan.

Analisis ekonomi politik (kelembagaan) menjadi instrumen peneliti untuk mendalami peran lembaga-lembaga yang terlibat maupun memberikan perhatian terhadap pemenuhan hak-hak pekerja migran. Lembaga yang terlibat dalam penelitian ini antara lain: Kementerian Kementerian Ketenagakerjaan RI, Kementerian Luar Negeri RI, Badan Nasional Penempatan dan Perlindungan TKI (BNP2TKI) sebagai wakil pemerintah pusat. Selanjutnya lembaga di daerah antara lain: BP3TKI yang merupakan instansi vertikal dari BNP2TKI bertugas mengkoordinasikan hal-hal terkait penempatan dan perlindungan TKI di daerah, Dinas Tenaga Kerja dan Transmigrasi Provinsi/Kabupaten/Kota sebagai institusi yang bertanggungjawab atas bidang ketenagakerjaan dan tentunya pemerintah provinsi Sulawesi Selatan yang memberikan perhatian kepada warganya yang mendorong pembangunan di daerah dengan mencari peluang kerja ke luar negeri. Sedangkan lembaga di luar pemerintah yang juga terkait dengan proses migrasi tenaga kerja ke luar 
negeri antara lain: Pelaksana Penempatan Tenaga Kerja Indonesia Swasta (PPTKIS) sebagai pihak swasta yang menyalurkan tenaga kerja Indonesia ke luar negeri maupun dan Pengguna/Majikan di negara penempatan sebagai pengguna jasa TKI, sedangkan masyarakat sipil (civil society) diwakili individu TKI/PMI, akademisi maupun Lembaga Swadaya Masyarakat (LSM) yang menaruh perhatian terhadap upaya pemenuhan hak-hak pekerja migran.

\section{Skema Pikir}

Skema pikir dalam penelitian ini disusun untuk memudahkan pemahaman terhadap luaran yang ingin dicapai dari penelitian ini. Dalam skema pikir penelitian ini digambarkan bahwa Pemenuhan Hak-Hak Pekerja Migran asal Sulawesi Selatan di Malaysia berdasarkan UU No. 39 Tahun 2004 pada masa pra-penempatan dan masa penempatan merupakan topik yang dikaji dan berada di tengah. Di tiga sisi dari sektor tersebut terdapat pemerintah, swasta dan masyarakat sipil yang merupakan lembaga/institusi yang berinteraksi dalam ekonomi politik. Selengkapnya dipaparkan sebagai berikut:

Bagan 2.5 Skema Pikir Analisis Ekonomi Politik Pemenuhan Hak-Hak Pekerja Migran Asal Sulawesi Selatan di Malaysia

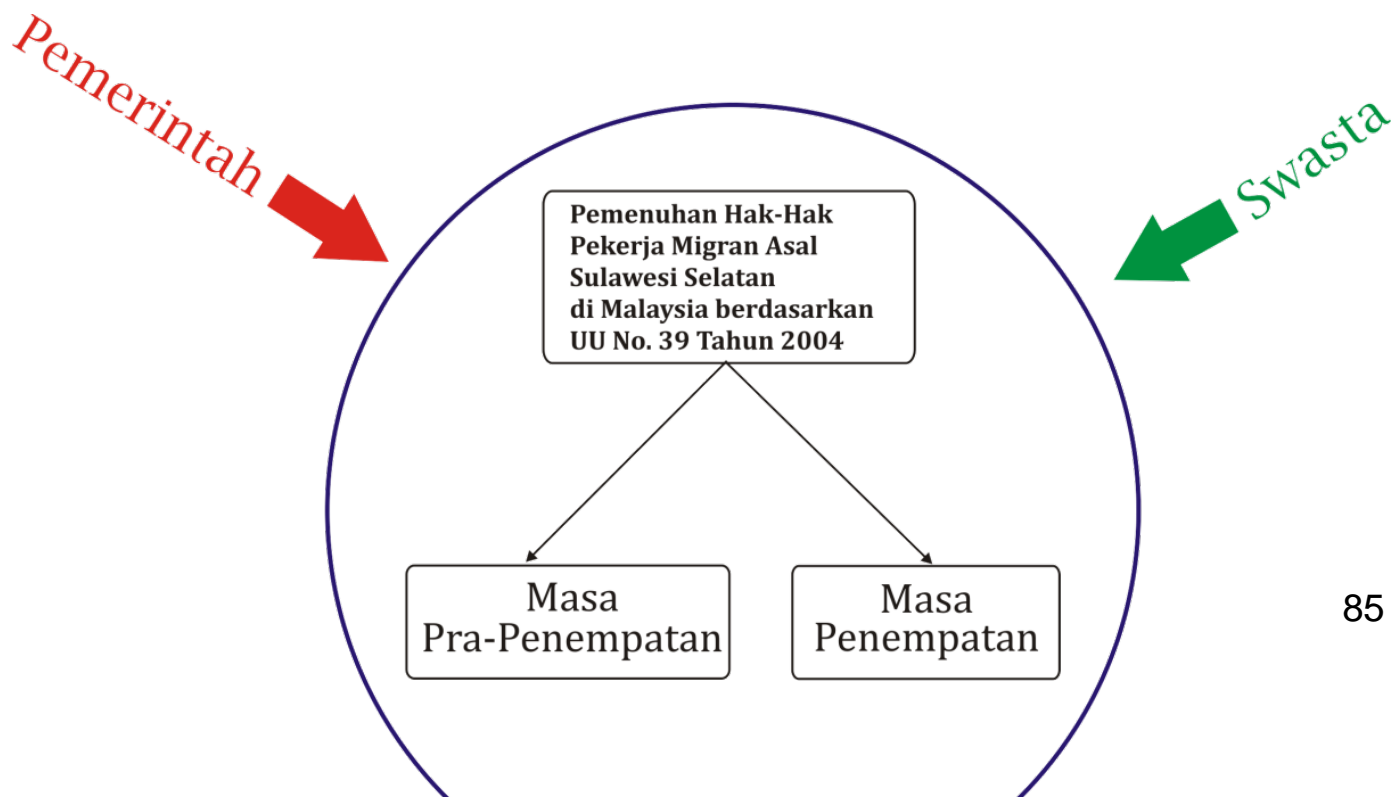




\section{BAB III \\ METODE PENELITIAN}

Bab ini membahas lima bagian antara lain: Tipe dan Dasar Penelitian, Lokasi Penelitian, Sumber Data, Teknik Pengumpulan Data dan Teknik Analisis Data.

\subsection{Tipe dan Dasar Penelitian}

Penelitian ini menggunakan tipe dan dasar metode kualitatif dengan pendekatan studi kasus. Bogdan dan Taylor (1990) mengemukakan penelitian kualitatif adalah prosedur penelitian yang menghasilkan data deskriptif berupa kata-kata tertulis atau lisan dari orang-orang dan perilaku yang dapat diamati. Moehar Daniel (2002:116) menyatakan bahwa metode studi kasus memiliki populasi yang lebih terarah atau terfokus pada sifat tertentu yang tidak berlaku umum. Biasanya dibatasi oleh kasus, lokasi, tempat tertentu, serta waktu tertentu. Metode pengambilan contoh dalam studi kasus tidak terlalu mengikat sejauh penetapan suatu kasus benar-benar tepat. ${ }^{1}$

Daniel juga menyatakan bahwa case (kasus) yang dimaksud dapat berbentuk satu individu, satu institut atau satu golongan yang dianggap sebagai satu satuan di dalam penelitian bersangkutan. Apapun yang menjadi satuan objek yang diteliti, case study (studi kasus) ini berusaha memberikan gambaran yang dirinci dengan tekanan pada situasi keseluruhan mengenai proses atau urutan suatu kejadian. Keuntungan dari suatu case study (studi kasus), peneliti akan mendapatkan gambaran

\footnotetext{
${ }^{1}$ Moehar Daniel, (2002), Metode Penelitian Sosial Ekonomi, Jakarta: Bumi Aksara. h .116.
} 
yang luas dan lengkap dari suatu obyek yang diteliti. ${ }^{2}$ Daniel menambahkan dalam melakukan case study langkah-langkah berikut dapat dijadikan sebagai tambahan dari langkah-langkah umum penelitian, yakni: (1) tentukan tujuan penelitian. Tujuan case study pada umumnya adalah satu di antara tiga tujuan berikut: (a) untuk mendapatkan keterangan-keterangan yang rinci mengenai suatu operasi, metode atau cara kerja (practice); (b) untuk mendapatkan data yang tepat dari suatu obyek; (c) untuk mendapatkan data perbandingan dari beberapa satuan obyek; (2) tentukan satuan case study yang akan dipakai; (3) tentukan pemilihan case yang akan dipakai; (4) tentukan jumlah case yang akan diteliti. Dalam case study, kasus yang diselidiki dapat berjumlah satu, beberapa buah atau banyak. ${ }^{3}$

Tujuan dari penelitian studi kasus yang dilakukan oleh peneliti adalah untuk mengetahui bagaimana pemenuhan hak-hak pekerja migran asal Sulawesi Selatan di Malaysia pada masa pra-penempatan dan masa penempatan. Satuan yang diteliti berasal dari unsur pemerintah, swasta dan masyarakat sipil. Pemilihan kasus berasal dari proses pada masa prapenempatan dan masa penempatan pekerja migran asal Sulsel.

\subsection{Lokasi Penelitian}

Penelitian ini dilaksanakan di Indonesia dan Malaysia. Lokasi penelitian di Indonesia yakni Provinsi Sulawesi Selatan dengan mengambil fokus di beberapa kabupaten/kota yakni: Kota Makassar, Kota Pare-Pare dan Kabupaten Gowa, Daerah Khusus Ibukota Jakarta dan

${ }^{2}$ Ibid. h. 117.

${ }^{3}$ Ibid. hh. 118-119 
Provinsi Kalimantan Utara dengan fokus di Kabupaten Nunukan. Sedangkan lokasi penelitian di Malaysia yakni Sabah dengan fokus di Tawau. Institusi dituju yakni pihak-pihak yang mewakili Pemerintah, Swasta dan Masyarakat Sipil.

\subsection{Sumber Data}

Sumber data yang digunakan dalam penelitian ini disesuaikan dengan objek penelitian, sehingga data-data yang dijadikan nantinya mampu memberikan gambaran tentang objek penelitian secara utuh. Sumber data penelitian ini digolongkan ke dalam dua kategori yakni data primer dan data sekunder.

Data primer diperoleh peneliti dengan melakukan penelitian lapangan (field research) untuk mengumpulkan data-data wawancara dengan narasumber yang telah ditentukan. Proses wawancara yang dilakukan menghimpun data-data seperti: kelembagaan pemerintah dan swasta dalam pemenuhan hak-hak pekerja migran asal Sulawesi Selatan di Malaysia pada masa pra-penempatan dan masa penempatan.

Sedangkan data sekunder diperoleh peneliti dengan melakukan telaah pustaka yakni mengumpulkan data dari buku, jurnal, media cetak dan elektronik, serta sumber informasi lainnya yang erat kaitannya dengan masalah penelitian.

\subsection{Teknik Pengumpulan Data}

Menurut Silalahi (2012:280), data merupakan bahan penting yang digunakan oleh peneliti untuk menjawab pertanyaan atau menguji hipotesis dan mencapai tujuan penelitian. Oleh karena itu, data dan 
kualitas data merupakan pokok penting dalam penelitian karena menentukan kualitas hasil penelitian. Data diperoleh melalui suatu proses yang disebut pengumpulan data. Pengumpulan data dapat didefinisikan sebagai satu proses mendapatkan data empiris melalui responden dengan menggunakan metode tertentu. ${ }^{4}$

Pengumpulan data dalam penelitian ini dilakukan dengan teknik wawancara mendalam (in-depth interview) mengacu pada pedoman wawancara (interview guide) agar wawancara tetap berada pada fokus penelitian, meski tidak menutup kemungkinan terdapat pertanyaanpertanyaan berlanjut. Proses pengumpulan diawali dengan membuat pedoman wawancara yang disusun berdasarkan indikator-indikator ekonomi politik yang telah dibahas pada tinjauan pustaka. Pedoman wawancara ini berisi pertanyaan-pertanyaan mendasar yang nantinya akan berkembang dalam wawancara. Wawancara mendalam dilaksanakan dengan membuat kesepakatan dengan informan mengenai waktu dan tempat untuk melakukan wawancara.

Penetapan informan dalam penelitian ini menggunakan metode purposive yakni peneliti menetapkan informan berdasarkan asumsi bahwa informan dapat memberikan informasi yang diperlukan dalam penelitian sesuai dengan pengetahuan maupun keterlibatan mereka dengan permasalahan yang diteliti. Memperhatikan karakteristik informan di atas, maka informan yang diwawancarai berasal dari institusi berikut:

Pusat

a. R.Soes Hindharno, S.H., Direktur Jenderal Penempatan dan Perlindungan Tenaga Kerja Luar Negeri, Kemenaker RI

\footnotetext{
${ }^{4}$ Ulber Silalahi, (2012), Metode Penelitian Sosial, Bandung: PT. Refika Aditama, h. 280.
} 
b. Krishna Djelani, Kepala Subdirektorat Pengawasan Kekonsuleran, Direktorat Perlindungan WNI dan BHI, Kemlu RI.

c. R. Wisantoro, Direktur Media dan Advokasi, Deputi III Bidang Perlindungan, BNP2TKI.

d. Mike Verawati, Project Officer Advokasi Buruh Migran berbasis Teknologi, LSM Migrant Care.

Daerah (Provinsi Sulawesi Selatan)

a. Dr. Syahrul Yasin Limpo, S.H., M.H., M.Si., Gubernur Sulawesi Selatan

b. Drs. H. Andi Marzkui Wadeng, Ketua Komisi E Dewan Perwakilan Rakyat Daerah (DPRD) Provinsi Sulawesi Selatan

c. Tenri Ulleng, S.S., M.Pd., Kasi Penyiapan Penempatan, Balai Pelayanan Penempatan dan Perlindungan Tenaga Kerja Indonesia (BP3TKI) Makassar

d. Nurmiati, S.Sos., M.M., Kasi Kelembagaan dan Pemasyarakatan Program, BP3TKI Makassar

e. Imrana Syatar, S.E., M.M., Kasi Perlindungan dan Pemberdayaan, BP3TKI Makassar

f. Balai Pelayanan Penempatan dan Perlindungan Tenaga Kerja Indonesia (BP3TKI) Nunukan

g. Zulkifli, S.E., Koordinator Pos Pelayanan Penempatan dan Perlindungan Tenaga Kerja Indonesia (P4TKI) Pare-Pare 
h. Dr. Syamsi Alang, M.M., Koordinator Fungsional Pengantar Kerja, Dinas Tenaga Kerja dan Transmigrasi Provinsi Sulawesi Selatan.

i. Andi Iskandar, Kepala Seksi Perluasan Kerja, Dinas Tenaga Kerja dan Transmigrasi Kota Makassar

j. Yusran, S.Pd., Kepala Bidang Penempatan Tenaga Kerja, Dinas Tenaga Kerja Kota Pare-Pare

k. Mustamin Raga, Dinas Tenaga Kerja dan Transmigrasi Kabupaten Gowa

I. Andi Nagauleng, S.E., Direktur Utama PT. Amalindo Bhakti Persada, Pare-Pare (PPTKIS)

m. Kartini Baharuddin F., S,Ag, Kepala Kantor Konsorsium Asuransi Tenaga Kerja Indonesia (ASTINDO) Perwakilan Daerah Sulawesi Selatan

Negara Penempatan (Tawau, Sabah, Malaysia)

a. Dian Ratri Astuti, Kepala Kanselerai/Fungsi Pensosbud, Konsulat Republik Indonesia (KRI) Tawau

b. Prakoso Wicaksono, Fungsi Ekonomi dan Protokol Kekonsuleran, KRI Tawau

c. Ujo Sujoto, Staf Teknis Imigrasi, KRI Tawau

d. Suhaili bin Ismail, Senior Assistant Director, Pejabat Tenaga Kerja Tawau, Jabatan Tenaga Kerja Sabah, Kementerian Sumber Manusia, Malaysia

e. Mostyn bin Marsuki, Direktur Agensi Pekerjaan Mospia 
f. Mustaslifah binti Mostyn, Bagian Pengurusan Agensi Pekerjaan Mospia

\subsection{Teknik Analisis Data}

Analisis data adalah proses penyederhanaan data dan penyajian data dengan mengelompokkannya dalam suatu bentuk yang mudah dibaca dan diinterpretasi. Menurut Nan Lin (1976) dalam Silalahi (2012:332), analisis data mempunyai dua tujuan yakni meringkas dan menggambarkan data (to summarize and describe the data) dan membuat inferensi dari data untuk populasi darimana sampel ditarik (to make inferences from the data to the population from which the sample was drawn). Kerlinger dalam Silalahi (2012:332) menyatakan analisis berarti kategorisasi, penataan, manipulasi dan peringkatan data untuk memperoleh jawaban atas pertanyaan penelitian. Kegunaan analisis ialah mereduksikan data menjadi perwujudan yang dapat dipahami dan ditafsir dengan cara tertentu hingga relasi masalah penelitian dapat ditelaah serta diuji. ${ }^{5}$

Teknik analisis data dalam penelitian ini menggunakan analisis data kualitatif. Analisis data kualitatif dilakukan apabila data empiris yang diperoleh adalah data kualitatif berupa kumpulan berwujud kata-kata dan bukan rangkaian angka serta tidak dapat disusun dalam kategorikategori/struktur klasifikasi. Data (dalam wujud kata-kata) mungkin telah dikumpulkan dalam aneka cara (observasi, wawancara, intisari dokumen, pita rekaman) dan biasanya "diproses" sebelum siap digunakan (melalui

\footnotetext{
${ }^{5}$ Ibid. hh. 331-332
} 
pencatatan, pengetikan, penyuntingan atau alih-tulis), tetapi analisis kualitatif tetap menggunakan kata-kata yang biasanya disusun ke dalam teks yang diperluas, dan tidak menggunakan perhitungan matematis atau statistika sebagai alat bantu analisis. ${ }^{6}$

Menurut Miles dan Huberman dalam Silalahi (2012:339), kegiatan analisis terdiri dari tiga alur kegiatan yang terjadi secara bersamaan, yaitu reduksi data, penyajian data, dan penarikan kesimpulan/verifikasi. Terjadi bersamaan berarti reduksi data, penyajian data dan penarikan kesimpulan/verifikasi sebagai sesuatu yang jalin menjalin merupakan proses siklus dan interaktif pada saat sebelum, selama dan sesudah pengumpulan data dalam bentuk sejajar untuk membangun wawasan umum yang disebut "analisis".

Bagan 3.1 Komponen-Komponen Analisis Data: Model Interaktif

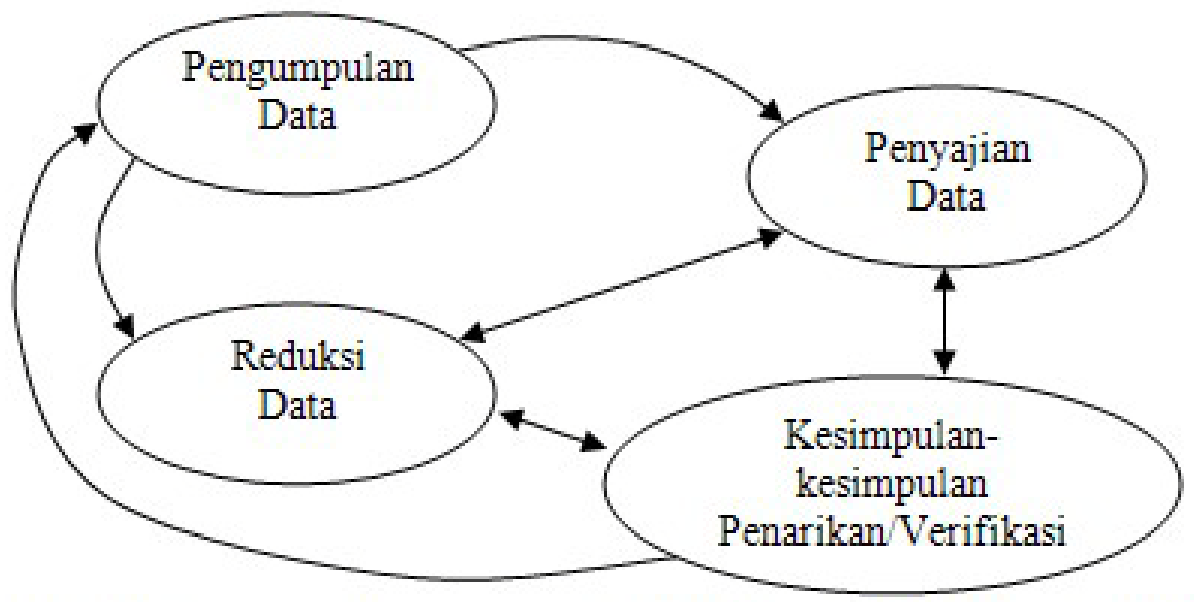

Sumber: Miles dan Huberman (1992:20) dalam Silalahi (2012:340)

Bagan 3.1 di atas merupakan komponen-komponen analisis data dengan model interaktif yang digunakan dalam penelitian ini. Deskripsi

${ }^{6}$ Ibid. h. 339. 
reduksi data, penyajian data dan menarik kesimpulan dijelaskan sebagai berikut:

\subsubsection{Reduksi Data}

Reduksi data merupakan suatu bentuk analisis yang menajamkan, menggolongkan, mengarahkan, membuang yang tidak perlu, dan mengorganisasi data sedemikian rupa sehingga kesimpulan-kesimpulan finalnya dapat ditarik dan diverifikasi. Reduksi data atau proses transformasi ini berlanjut terus sesudah penelitian lapangan, sampai laporan akhir lengkap tersusun. Jadi dalam penelitian kualitatif, "reduksi data" tidak perlu mengartikannya sebagai kuantifikasi. Data kualitatif dapat disederhanakan dan ditransformasikan dalam aneka macam cara: melalui seleksi ketat, melalui ringkasan atau uraian singkat, menggolongkan dalam suatu pola yang lebih luas dan sebagainya. ${ }^{7}$

Langkah-langkah yang ditempuh dalam mereduksi data hasil wawancara yakni hasil wawancara yang telah direkam melalui alat perekam, handphone maupun catatan tertulis diinventaris/dikumpulkan. Selanjutnya dilakukan proses pembersihan dengan data-data yang diperoleh dengan cara, hasil rekaman didengarkan dan dibuat transkrip sesuai dengan keadaannya, selanjutnya transkrip tersebut dirapikan dan diperbaiki seperlunya agar teratur dan sistematis.

\subsubsection{Penyajian Data}

Penyajian data merupakan alur kedua yang penting dalam kegiatan analisis data kualitatif. Penyajian data yaitu sekumpulan informasi

\footnotetext{
${ }^{7}$ Ulber Silalahi, hh. 339-340.
} 
tersusun yang memberi kemungkinan adanya penarikan kesimpulan dan pengambilan tindakan. Melalui data yang disajikan, kita melihat dan akan dapat memahami apa yang sedang terjadi dan apa yang harus dilakukanlebih jauh menganalisis ataukah mengambil tindakan berdasarkan atas pemahaman yang didapat dari penyajian-penyajian tersebut. $^{8}$

Penyajian data penelitian ini menempatkan data yang hasil wawancara dan hasil telaah pustaka pada posisinya sesuai dengan kerangka hasil dan pembahasan yang disusun mengacu pada rumusan masalah yakni pemenuhan hak-hak pekerja migran asal Sulawesi Selatan di Malaysia pada masa pra-penempatan dan masa penempatan.

\subsubsection{Penarikan Kesimpulan}

Kegiatan analisis yang ketiga adalah menarik kesimpulan dan verifikasi. Ketika kegiatan pengumpulan data dilakukan, seorang penganalisis kualitatif mulai mencari arti benda-benda, mencatat keteraturan, pola-pola, penjelasan, konfigurasi-konfigurasi yang mungkin, alur sebab akibat dan proposisi. Mula-mula kesimpulan belum jelas, tetapi kemudian kian meningkat menjadi lebih terperinci. Kesimpulankesimpulan "final" mungkin tidak muncul sampai pengumpulan data berakhir, bergantung pada besarnya kumpulan-kumpulan catatan lapangan, pengkodeannya, penyimpanan dan metode pencarian ulang yang digunakan, kecakapan peneliti, dan tuntutan pemberi dana, tetapi seringkali kesimpulan itu telah dirumuskan sejak awal, sekalipun seorang peneliti menyatakan telah melanjutkanya "secara induktif". 9

\footnotetext{
${ }^{8}$ Ibid. h. 340.

9 Ibid.
} 
Kesimpulan-kesimpulan diverifikasi selama penelitian berlangsung. Verifikasi itu mungkin sesingkat pemikiran kembali yang melintas dalam pikiran penganalisis selama dia menulis, suatu tinjauan ulang pada catatan-catatan lapangan atau mungkin begitu seksama dengan peninjauan kembali untuk mengembangkan "kesepakatan intersubjektif". Singkatnya, makna-makna yang muncul dari data harus diuji kebenarannya, kekukuhannya dan kecocokannya yakni merupakan validitasnya. Jika tidak demikian, yang kita miliki adalah cita-cita yang menarik mengenai sesuatu yang terjadi dan yang tidak jelas kebenarannya dan kegunaannya. ${ }^{10}$

Proses penarikan kesimpulan dalam penelitian ini dilakukan dari kumpulan data dan informasi yang diolah dan dianalisa dengan melihat bagaimana pemenuhan hak-hak pekerja migran asal Sulawesi Selatan di Malaysia pada masa pra-penempatan dan masa penempatan yang disimpulkan berdasarkan data yang telah dianalisis dari sumber data primer (wawancara) dan data sekunder (buku, jurnal dan dokumen).

10 Ibid. 


\section{BAB IV \\ GAMBARAN OBJEK PENELITIAN}

Bab ini membahas tiga bagian yang menjadi objek penelitian yakni: statistik penempatan dan negara tujuan pekerja migran Indonesia, pemetaan masalah pekerja migran Indonesia, statistik pengaduan pekerja migran Indonesia dan struktur UU No. 39 Tahun 2004.

\subsection{Statistik Penempatan dan Negara Tujuan Pekerja Migran Indonesia}

Statistik penempatan pekerja migran Indonesia ini merupakan data kompilasi dari Badan Nasional Penempatan dan Perlindungan TKI (BNP2TKI) yang bertanggungjawab terhadap penempatan dan perlindungan TKI. Berikut data penempatan TKI dalam 5 tahun terakhir (2011-2015).

Grafik 4.1 Penempatan Tenaga Kerja Indonesia Tahun 2011-2015

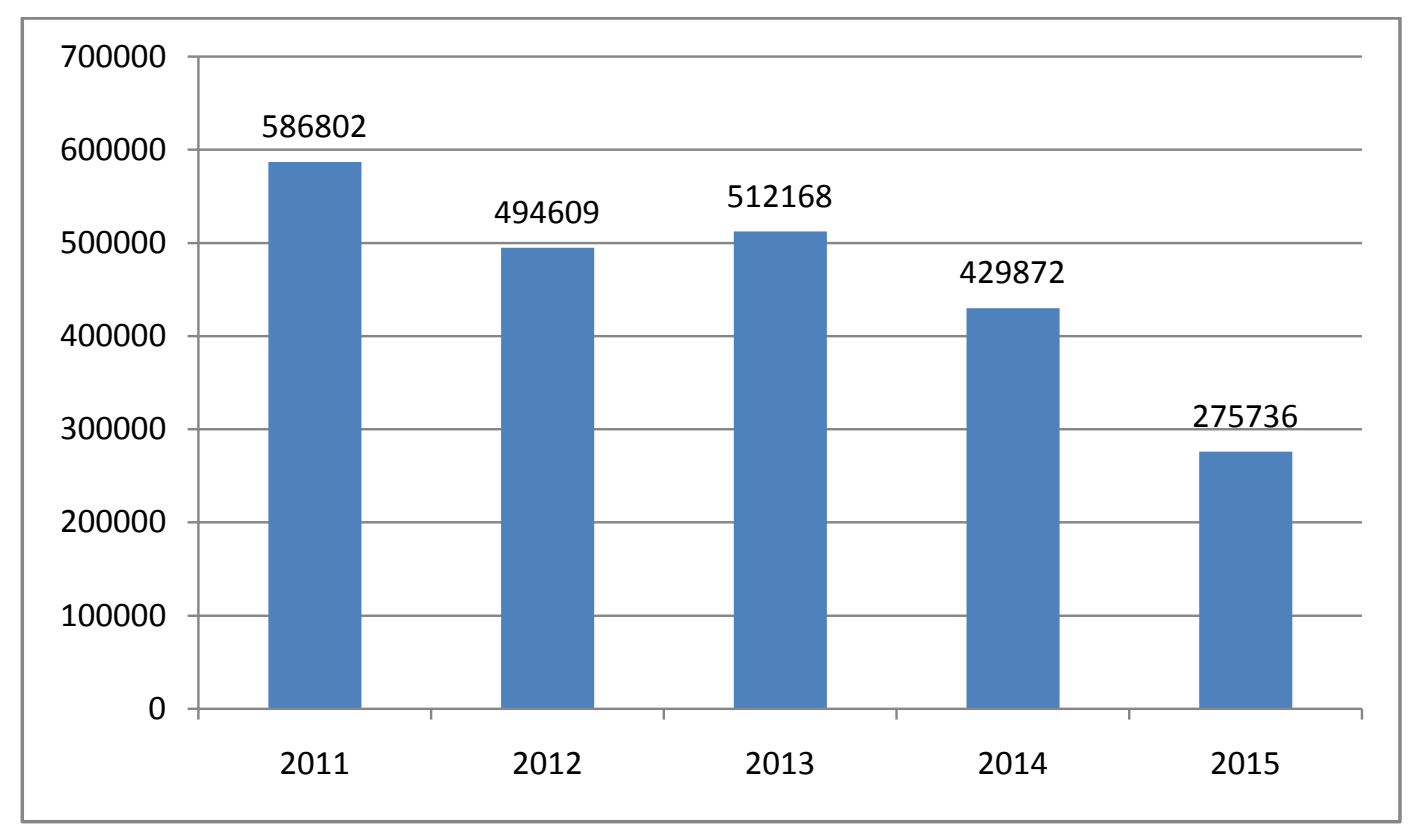

Sumber: Data Penempatan dan Perlindungan TKI Tahun 2015 (BNP2TKI) 
Data di atas menunjukkan penempatan TKI dari tahun 2011 hingga 2015 mengalami penurunan yang signifikan. Walaupun pada tahun 2013 sempat mengalami kenaikan, tetapi penempatan TKI pada tahun 2015 jika dibandingkan tahun sebelumnya (2014) mengalami penurunan yang drastis.

Lebih spesifik penempatan tenaga kerja luar negeri Indonesia berdasarkan provinsi dalam 5 tahun terakhir (2011-2015) sebagai berikut:

Tabel 4.1 Penempatan Tenaga Kerja Luar Negeri Indonesia Berdasarkan Provinsi Periode 2011-2015

\begin{tabular}{|c|c|c|c|c|c|c|}
\hline \multirow{2}{*}{ No. } & \multirow{2}{*}{ Provinsi } & \multicolumn{5}{|c|}{ Tahun } \\
\hline & & $2011^{*}$ & $2012^{* *}$ & $2013^{\star *}$ & $2014^{\star \star}$ & $2015^{\star \star}$ \\
\hline 1. & Jawa Barat & 145.603 & 119.620 & 129.885 & 105.479 & 63.102 \\
\hline 2. & Jawa Tengah & 123.154 & 115.456 & 105.971 & 92.590 & 57.077 \\
\hline 3. & Jawa Timur & 109.233 & 100.368 & 93.843 & 78.306 & 48.312 \\
\hline 4. & Nusa Tenggara Barat & 72.835 & 46.245 & 63.438 & 61.139 & 51.743 \\
\hline 5. & Lampung & 17.085 & 16.259 & 17.975 & 18.500 & 16.109 \\
\hline 6. & Sumatera Utara & 12.447 & 13.728 & 13,299 & 14.782 & 12.054 \\
\hline 7. & DKI Jakarta & 18.718 & 15.021 & 14.248 & 7.561 & 1.212 \\
\hline 8. & Bali & 15.066 & 14.082 & 14.617 & 7.716 & 4.869 \\
\hline 9. & Banten & 27.576 & 10.853 & 13.244 & 9.720 & 4.257 \\
\hline 10. & Sulawesi Selatan & 13.948 & 13.875 & 10.358 & 7.497 & 2.348 \\
\hline 11. & Nusa Tenggara Timur & 10.905 & 8.328 & 5.308 & 5.515 & 3.307 \\
\hline 12. & Kalimantan Barat & 1.689 & 2.607 & 10.091 & 5.190 & 2.221 \\
\hline 13. & DI Yogyakarta & 4.395 & 4.620 & 4.967 & 3.808 & 1.856 \\
\hline 14. & Sumatera Selatan & 2.233 & 1.874 & 2.662 & 1.958 & 1.403 \\
\hline 15. & Sulawesi Utara & 1.196 & 1.742 & 1.543 & 1.076 & 428 \\
\hline 16. & Kepulauan Riau & 1.179 & 1.427 & 1.540 & 1.223 & 804 \\
\hline 17. & Sumatera Barat & 960 & 1.176 & 1.639 & 1.227 & 789 \\
\hline 18. & Sulawesi Tengah & 1.273 & 820 & 1.066 & 896 & 586 \\
\hline 19. & Aceh & 1.490 & 762 & 910 & 951 & 786 \\
\hline 20. & Jambi & 578 & 747 & 934 & 835 & 528 \\
\hline 21. & Kalimantan Selatan & 1.250 & 797 & 888 & 711 & 422 \\
\hline 22. & Kalimantan Timur & 665 & 959 & 716 & 449 & 179 \\
\hline 23. & Riau & 495 & 459 & 717 & 868 & 556 \\
\hline 24. & Sulawesi Tenggara & 496 & 641 & 689 & 423 & 135 \\
\hline 25. & Sulawesi Barat & 1.082 & 625 & 542 & 450 & 132 \\
\hline 26. & Maluku & 462 & 353 & 325 & 312 & 78 \\
\hline 27. & Bengkulu & 373 & 317 & 334 & 319 & 294 \\
\hline 28. & Bangka Belitung & 225 & 144 & 110 & 49 & 22 \\
\hline
\end{tabular}




\begin{tabular}{|c|c|c|c|c|c|c|}
\hline 29. & Maluku Utara & 54 & 44 & 56 & 121 & 85 \\
\hline 30. & Papua & 85 & 47 & 110 & 48 & 8 \\
\hline 31. & Kalimantan Tengah & 107 & 67 & 60 & 69 & 24 \\
\hline 32. & Papua Barat & 73 & 75 & 54 & 47 & 6 \\
\hline 33. & Gorontalo & 52 & 46 & 29 & 37 & 4 \\
\hline & Total & 586.802 & 494.609 & 512.168 & 429.872 & 275.736 \\
\hline
\end{tabular}

Data di atas menunjukkan bahwa TKI asal Jawa Barat menempati posisi pertama, diikuti TKI asal Jawa Tengah, Jawa Timur, Nusa Tenggara Barat, Lampung, Sumatera Utara, DKI Jakarta, Bali dan Banten. Di posisi kesepuluh ditempati TKI asal Sulawesi Selatan. Jumlah TKI asal Sulawesi Selatan tercatat menurun signifikan dari tahun 2012 hingga 2015.

Pekerja migran Indonesia tersebar di 170 negara berdasarkan 25 negara penempatan dengan jumlah TKI terbesar dipaparkan sebagai berikut:

Tabel 4.2 Negara Penempatan Tenaga Kerja Luar Negeri Indonesia Periode 2011-2015

\begin{tabular}{|c|c|c|c|c|c|c|}
\hline \multirow{2}{*}{ No. } & \multirow{2}{*}{ Negara } & \multicolumn{5}{|c|}{ Tahun } \\
\hline & & $2011^{*}$ & $2012^{\star \star}$ & $2013^{\star \star}$ & $2014^{\star \star}$ & $2015^{\star \star}$ \\
\hline 1. & Malaysia & 134.120 & 134,069 & 150,250 & 127,827 & 97,635 \\
\hline 2. & Taiwan & 78.865 & 81,071 & 83,544 & 82,665 & 75,303 \\
\hline 3. & Saudi Arabia & 137.835 & 40,655 & 45,394 & 44,325 & 23,000 \\
\hline 4. & Hongkong & 50.301 & 45,478 & 41,769 & 35,050 & 15,322 \\
\hline 5. & Singapura & 47.786 & 41,556 & 34,655 & 31,680 & 20,895 \\
\hline 6. & Uni Emirat Arab & 39.917 & 35,888 & 44,505 & 17,962 & 7,619 \\
\hline 7. & Qatar & 16.616 & 20,380 & 16,237 & 7,862 & 2,460 \\
\hline 8. & Korea Selatan & 11.392 & 13,593 & 15,374 & 11,848 & 5,501 \\
\hline 9. & Amerika Serikat & 13.749 & 15,353 & 15,021 & 9,233 & 1,029 \\
\hline 10. & Oman & 7.306 & 10,719 & 10,719 & 10,719 & 6,766 \\
\hline 11. & Brunei Darussalam & 10.804 & 13,146 & 11,269 & 11,616 & 9,993 \\
\hline 12. & Bahrain & 4.379 & 6,328 & 5,384 & 5,472 & 2,570 \\
\hline 13. & Jepang & 2.508 & 3,293 & 3,042 & 2,428 & 468 \\
\hline 14. & Italia & 3.408 & 3,691 & 3,746 & 1,295 & 1,516 \\
\hline 15. & Kuwait & 2.723 & 2,518 & 2,534 & 1,714 & 210 \\
\hline 16. & China & 1.072 & 1,967 & 2,055 & 915 & 108 \\
\hline 17. & Spanyol & 1.484 & 1,746 & 1,417 & 889 & 268 \\
\hline 18. & Turki & 1.016 & 1,209 & 1,518 & 1,246 & 1,108 \\
\hline
\end{tabular}




\begin{tabular}{|l|l|r|r|r|r|r|}
\hline 19. & Afrika Selatan & 1.272 & 1,388 & 905 & 587 & 113 \\
\hline 20. & Mauritius & 478 & 982 & 1,017 & 838 & 144 \\
\hline 21. & Thailand & 1.113 & 1,035 & 1,041 & 717 & 90 \\
\hline 22. & Belanda & 592 & 798 & 1,176 & 796 & 52 \\
\hline 23. & Kepulauan Fiji & 556 & 970 & 848 & 902 & 246 \\
\hline 24. & Australia & 526 & 945 & 1,012 & 644 & 77 \\
\hline 25. & Jerman & 299 & 697 & 1,168 & 556 & 194 \\
\hline 26. & Lainnya & 59.059 & 17,017 & 16,568 & 11,664 & 3,049 \\
\hline \multicolumn{2}{|c|}{ Total } & 586.802 & 494,609 & 512,168 & 429,872 & 275,736 \\
\hline
\end{tabular}

Sumber: Data Penempatan dan Perlindungan TKI Tahun *2011-2013 \& **2015 (BNP2TKI)

Data di atas menunjukkan Malaysia merupakan negara tujuan dengan penempatan tertinggi setiap tahun selama 5 tahun terakhir (20112015). Di posisi berikutnya adalah Taiwan, Saudi Arabia, Hongkong dan Singapura di urutan kelima. Jika diperhatikan seksama penempatan TKI di Malaysia relatif stabil pada 2011 dan 2012, kemudian terjadi peningkatan pada 2013 dan penurunan kembali pada 2014. TKI pada tahun 2015 mengalami penurunan yang cukup besar jika dibandingkan tahun-tahun sebelumnya.

Selanjutnya dipaparkan posisi/jabatan yang ditempati oleh TKI di negara penempatan, sebagai berikut:

Tabel 4.3 Jabatan TKI di Negara Penempatan Periode 2011-2015

\begin{tabular}{|c|c|c|c|c|c|c|}
\hline \multirow{2}{*}{ No. } & \multirow{2}{*}{ Jabatan } & \multicolumn{5}{|c|}{ Tahun } \\
\hline & & $2011^{*}$ & $2012^{\star \star}$ & $2013^{\star \star}$ & $2014^{\star *}$ & $2015^{\star \star}$ \\
\hline 1. & Dosmetic Worker & 267.231 & 164.981 & 168.318 & 133.390 & 52.328 \\
\hline 2. & Caregiver/Caretaker & 48.492 & 52.565 & 48.188 & 49.069 & 44.941 \\
\hline 3. & Plantation Worker & 39.622 & 36.478 & 47.598 & 47.790 & 38.526 \\
\hline 4. & Operator & 40.847 & 40.347 & 46.799 & 38.836 & 35.187 \\
\hline 5. & Deck Hand & - & 12.283 & 11.249 & 10.410 & 1.166 \\
\hline 6. & Lainnya & 191.610 & 187.955 & 190.016 & 150.377 & 103.588 \\
\hline \multicolumn{2}{|r|}{ Total Keseluruhan } & 586.802 & 494,609 & 512,168 & 429,872 & 275,736 \\
\hline
\end{tabular}

Data di atas menunjukkan 5 jabatan teratas yang ditempati oleh TKI di negara penempatan. Posisi pertama ditempati oleh TKI yang 
bekerja sebagai domestic worker / penata laksana rumah tangga, selanjutnya caregiver/caretaker di posisi kedua, posisi ketiga ditempati plantation worker, posisi keempat oleh operator dan posisi kelima ditempati deck hand.

\subsection{Pemetaan Masalah Pekerja Migran Indonesia}

Permasalahan yang dihadapi oleh pekerja migran Indonesia yang ditempatkan ke luar negeri telah dipetakan oleh pemerintah melalui BNP2TKI yang dinyatakan dalam Peraturan Kepala BNP2TKI No. Per. 13/KA/VII/2012 tentang Standar Pelayanan Perlindungan Tenaga Kerja Indonesia yang merupakan turunan payung kebijakan UU No. 39 Tahun 2004 tentang Penempatan dan Perlindungan TKI di Luar Negeri. Bab III aturan ini membahas permasalahan CTKI/TKI dan Penanganannya sebagai upaya memetakan permasalahan yang dihadapi CTKI/TKI pada pra-penempatan, penempatan dan purna penempatan.

Permasalahan CTKI/TKI pada pra penempatan antara lain:

1. Gagal berangkat: CTKI yang telah ditampung dan telah menandatangani perjanjian penempatan dengan PPTKIS gagal berangkat.

2. Penipuan: CTKI yang telah direkrut dan dipungut biaya oleh PPTKIS maupun perorangan yang tidak dapat ditempatkan akibat tidak adanya Job Order dan persyaratan dokumen.

3. Dokumen tidak lengkap: TKI diberangkatkan tidak dilengkapi dokumen sesuai ketentuan yang berlaku. 
4. Sakit: TKI menderita sakit yang disebabkan kecelakaan, penganiayaan, cuaca, ingat/kangen kampung halaman (homesick) setelah di luar negeri, depresi dan lain-lain.

5. TKI hamil: TKI hamil yang disebabkan oleh pihak keluarga, maupun orang lain yang bukan kehendak dari TKI.

6. Usia TKI di bawah umur: umur TKI di bawah usia minimum yang dipersyaratkan.

7. TKI meninggal dunia: disebabkan sakit, kecelakaan, dibunuh atau bunuh diri, meninggal karena takdir.

Permasalahan TKI yang terjadi pada masa penempatan, antara lain:

1. Putus komunikasi: TKI yang telah ditempatkan oleh PPTKIS sejak keberangkatan hingga saat pengaduan dari pihak keluarga, tidak ada komunikasi baik dengan keluarga maupun PPTKIS.

2. Komunikasi tidak lancar: TKI tidak dapat berkomunikasi secara baik dalam bahasa Negara penempatan dengan pengguna.

3. Gaji tidak dibayar: TKI tidak memperoleh gaji selama bekerja atau sebagian dari masa kerjanya.

4. Under-paid: Gaji TKI dibayar tidak sesuai/di bawah yang tertera dalam perjanjian kerja.

5. Tidak mampu bekerja: TKI tidak dapat/tidak mampu melaksanakan tugas pekerjaan sesuai dengan perjanjian kerja. 
6. Penganiayaan: TKI mendapatkan penganiayaan atau tindak kekerasan dari pengguna/keluarga pengguna/agensi yang disebabkan kurang terampil maupun kurang lancar berbahasa negara penempatan maupun sebab lainnya.

7. Pelecehan seksual: Sesuai perbuatan yang dilakukan oleh pengguna maupun pihak lain terhadap TKI yang melanggar norma-norma susila.

8. Pengguna meninggal: pengguna meninggal dunia sehingga TKI dipulangkan ke negara asal dan hak-haknya belum terpenuhi.

9. Pekerjaan tidak sesuai perjanjian kerja (PK): TKI dipekerjakan pada pekerjaan yang tidak sesuai dengan perjanjian kerja.

10.Pemutusan hubungan kerja (PHK) sepihak: TKI yang dipekerjakan dipulangkan oleh pengguna ke Negara asal tanpa diketahui sebab/alasan yang jelas bukan karena kesalahan TKI.

11. Kecelakaan kerja: TKI yang mengalami kecelakaan pada saat melakukan pekerjaan.

12. Sakit: TKI menderita sakit yang disebabkan kecelakaan, penganiayaan, pekerjaan berat, cuaca, homesick, dan sebagainya yang berakibat cacat permanen, cacat sebagian, depresi dan sebagainya.

13.Pengguna pindah ke luar negeri: TKI dipulangkan akibat pengguna pindah ke luar negeri, apabila TKI tidak mau dibawa serta atau tidak mendapatkan izin KBRI. 
14. TKI ganti pengguna dan pindah ke negara lain: TKI pindah pada pengguna yang lain ke Negara yang berbeda tanpa memperoleh hak-haknya.

15. TKI hamil: TKI hamil akibat perbuatan pengguna, keluarga maupun orang lain.

16. Depresi/gangguan jiwa: TKI mengalami gangguan jiwa akibat tekanan mental.

17. TKI meninggal dunia: TKI meninggal disebabkan karena sakit, kecelakaan, penganiayaan, pembunuhan, bunuh diri atau karena takdir.

18. TKI berbuat kriminal: TKI yang melakukan pembunuhan, pencurian, perampokan, penipuan, pemerkosaan maupun narkotika.

19.Pemerasan: TKI mengalami pemerasan sehingga mengalami kerugian kehilangan yang dilakukan oleh pengguna/agensi/pihak-pihak lain di negara penempatan.

20.Potongan gaji tidak sesuai dengan ketentuan: Gaji TKI yang dipotong oleh agensi melebihi batas waktu dan besaran.

21. TKI kabur: TKI melarikan diri dari pengguna.

22. Pengguna/pabrik bangkrut: Pengguna tidak mampu lagi membayar gaji TKI.

23.TKI gagal ditempatkan oleh agensi: Setelah sampai di luar negeri, TKI gagal ditempatkan akibat tidak sesuai dengan kriteria yang berlaku di negara penempatan. 
24. TKI di bawah umur: Usia TKI di bawah usia minimum yang ditetapkan.

25. Data TKI dalam paspor tidak sesuai dengan aslinya: Nama, alamat, tanggal lahir, dan wajah TKI di dalam paspor tidak sama dengan aslinya.

26. TKI melakukan demonstrasi atau unjuk rasa: TKI melakukan demonstrasi atau unjuk rasa yang melanggar hukum Negara setempat yang disebabkan karena ketidakpuasan terhadap perlakuan pengguna.

27. TKI membawa jimat/izim: TKI yang membawa jimat atau sesuatu barang yang mencurigakan dan oleh majikan hal tersebut dianggap/merupakan ilmu sihir.

28. TKI koma: TKI yang sakit karena tidak sadar sampai batas waktu yang tidak dapat ditentukan.

Permasalahan TKI yang terjadi pada purna-penempatan (sejak tiba di bandara/pelabuhan laut di Indonesia sampai ke daerah asal), antara lain:

1. TKI meninggal dunia: TKI meninggal dunia disebabkan karena sakit, kecelakaan, penganiayaan, pembunuhan, maupun bunuh diri.

2. Pemerasan: TKI mengalami tekanan/paksaan dari pihak/oknum tertentu yang mengakibatkan kerugian/kehilangan pada saat pulang ke daerah asal. 
3. TKI pulang membawa anak: TKI pulang membawa anak akibat perbuatan TKI dengan pengguna maupun dengan orang lain.

4. Sakit: TKI menderita sakit yang disebabkan kecelakaan, penganiayaan, pekerjaan berat, cuaca, ingat/kangen kampung halaman (homesick) dan sebagainya yang dapat berakibat cacat permanen, cacat sebagian atau depresi.

5. TKI koma: TKI yang sakit karena tidak sadar sampai batas waktu yang tidak dapat ditentukan.

6. Kecelakaan: TKI mengalami kecelakaan pada saat pulang ke daerah asal.

7. TKI berbuat kriminal: TKI melakukan pencurian, penipuan, penggelapan dan tindak kriminal lainnya.

8. Pelecehan seksual: TKI yang dalam perjalanan menuju daerah asal mendapat pelecehan seksual dari pihak/oknum tertentu.

9. Penipuan: TKI saat pulang ke daerah asal mengalami penipuan.

10. TKI pulang membawa anak: TKI pulang membawa anak akibat perbuatan TKI dengan majikan maupun dengan orang lain.

\subsection{Statistik Pengaduan Pekerja Migran Indonesia}

Pemetaan masalah yang telah dipaparkan pada bagian sebelumnya merupakan gambaran secara umum. Namun, secara empiris, permasalahan yang dihadapi pekerja migran Indonesia dan asal Sulawesi Selatan di Malaysia dipaparkan dalam data statistik mengenai pengaduan dan kasus TKI/PMI secara nasional, sebagai berikut: 
Tabel 4.4 Status Pengaduan TKI 2012-2015

\begin{tabular}{|c|l|r|r|r|r|r|r|}
\hline \multirow{2}{*}{ No } & Statistik & \multicolumn{5}{|c|}{ Tahun } & \multirow{2}{*}{ Total } \\
\cline { 2 - 7 }. & Pengaduan & 2011 & 2012 & 2013 & 2014 & 2015 & \\
\hline 1. & Pengaduan Baru & 0 & 0 & 0 & 0 & 0 & 0 \\
\hline 2. & Proses Validasi & 11 & 42 & 49 & 163 & 261 & 526 \\
\hline 3. & Proses Distribusi & 28 & 304 & 198 & 311 & 314 & 1.155 \\
\hline 4. & Internal BNP2TKI & 162 & 643 & 625 & 545 & 858 & 2.833 \\
\hline 5. & Eksternal BNP2TKI & 43 & 116 & 269 & 317 & 605 & 1.350 \\
\hline 6. & Pengaduan Selesai & 4.376 & 4.320 & 3.291 & 2.607 & 2.856 & 17.450 \\
\hline \multicolumn{2}{|c|}{ Total Pengaduan } & 4.620 & 5.425 & 4.432 & 3.943 & 4.894 & 23.314 \\
\hline
\end{tabular}

Sumber: Data Penempatan dan Perlindungan TKI 2015 (BNP2TKI)

Keterangan: (1) Pengaduan yang masuk rata-rata 14 pengaduan per-hari dan diselesaikan 10 pengaduan per-hari; dan (2) Total Kasus yang telah diselesaikan BNP2TKI tahun 2011 s.d 2015 sejumlah 17.450 pengaduan

Tabel 4.5 Pengaduan Berdasarkan Provinsi 2012-2015

\begin{tabular}{|c|l|r|r|r|r|r|}
\hline \multirow{2}{*}{ No. } & \multirow{2}{*}{ Provinsi } & \multicolumn{4}{|c|}{ Tahun } & \multirow{2}{*}{ Total } \\
\cline { 3 - 6 } & & 2012 & 2013 & 2014 & 2015 & \\
\hline 2 & Jawa Barat & 2,497 & 1,848 & 1,343 & 1,846 & 7,534 \\
\hline 3 & Jusa Tenggara Barat & 711 & 549 & 424 & 487 & 2,171 \\
\hline 4 & Jawa Tengah & 378 & 340 & 426 & 447 & 1,591 \\
\hline 5 & Banten & 246 & 272 & 286 & 607 & 1,411 \\
\hline 6 & Nusa Tenggara Timur & 269 & 195 & 179 & 132 & 775 \\
\hline 7 & Lampung & 111 & 98 & 181 & 465 & 817 \\
\hline 8 & DKI Jakarta & 152 & 79 & 103 & 206 & 500 \\
\hline 9 & Sumatera Utara & 40 & 46 & 73 & 39 & 308 \\
\hline 10 & Sulawesi Selatan & $\mathbf{3 1}$ & $\mathbf{4 1}$ & $\mathbf{6 2}$ & 137 & 296 \\
\hline 11 & Sumatera Selatan & 51 & 34 & 22 & 43 & $\mathbf{2 5 1}$ \\
\hline 12 & DI Yogyakarta & 33 & 27 & 30 & 38 & 150 \\
\hline 13 & Kalimantan Barat & 18 & 42 & 18 & 30 & 128 \\
\hline 14 & Sulawesi Tengah & 21 & 16 & 31 & 32 & 108 \\
\hline 15 & Bali & 21 & 15 & 27 & 23 & 86 \\
\hline 16 & Sulawesi Utara & 18 & 24 & 21 & 30 & 93 \\
\hline 17 & Aceh & 0 & 23 & 25 & 79 & 127 \\
\hline 18 & Kalimantan Selatan & 18 & 11 & 9 & 19 & 57 \\
\hline 19 & Jambi & 1 & 5 & 20 & 25 & 51 \\
\hline 20 & Kepulauan Riau & 7 & 7 & 8 & 10 & 32 \\
\hline 21 & Maluku & 13 & 8 & 1 & 1 & 23 \\
\hline 22 & Bengkulu & 11 & 3 & 3 & 4 & 21 \\
\hline 23 & Sulawesi Tenggara & 4 & 8 & 5 & 16 & 33 \\
\hline 24 & Kalimantan Timur & 1 & 1 & 8 & 14 & 24 \\
\hline 25 & Sulawesi Barat & 2 & 2 & 6 & 12 & 22 \\
\hline
\end{tabular}




\begin{tabular}{|r|l|r|r|r|r|r|}
\hline 26 & Riau & 1 & 5 & 3 & 18 & 27 \\
\hline 27 & Sumatera Barat & 3 & 1 & 4 & 7 & 15 \\
\hline 28 & Maluku Utara & 0 & 1 & 5 & 3 & 9 \\
\hline 29 & Kalimantan Tengah & 1 & 3 & 1 & 0 & 5 \\
\hline 30 & Gorontalo & 1 & 0 & 4 & 2 & 7 \\
\hline 31 & Papua Barat & 0 & 0 & 1 & 2 & 3 \\
\hline 32 & Lainnya & 693 & 648 & 586 & 2 & 1,929 \\
\hline \multicolumn{2}{|c|}{ Total } & 5,426 & 4,432 & 3,953 & 4,894 & 18,075 \\
\hline
\end{tabular}

Sumber: Data Penempatan dan Perlindungan TKI 2015 (BNP2TKI)

Data di atas menunjukkan bahwa pekerja migran asal Sulawesi Selatan dengan jumlah pengaduan relatif kecil dalam 4 tahun terakhir (2012-2015).

Tabel 4.6 Pengaduan Berdasarkan Negara Penempatan 2012-2015

\begin{tabular}{|c|c|c|c|c|c|c|}
\hline \multirow{2}{*}{ No. } & \multirow{2}{*}{ Negara } & \multicolumn{4}{|c|}{ Tahun } & \multirow{2}{*}{ Total } \\
\hline & & 2012 & 2013 & 2014 & 2015 & \\
\hline 1 & Arab Saudi & 2,769 & 1,863 & 1,296 & 1,103 & 7,031 \\
\hline 2 & Malaysia & 613 & 723 & 893 & 1,994 & 4,223 \\
\hline 3 & Uni Emirat Arab & 305 & 262 & 280 & 264 & 1,111 \\
\hline 4 & Taiwan & 204 & 345 & 277 & 274 & 1,100 \\
\hline 5 & Suriah & 345 & 166 & 129 & 99 & 739 \\
\hline 6 & Jordania & 282 & 188 & 132 & 70 & 672 \\
\hline 7 & Singapura & 149 & 110 & 154 & 154 & 567 \\
\hline 8 & Oman & 109 & 147 & 155 & 158 & 569 \\
\hline 9 & Qatar & 94 & 189 & 126 & 93 & 502 \\
\hline 10 & Kuwait & 138 & 86 & 55 & 56 & 335 \\
\hline 11 & Hongkong & 76 & 86 & 89 & 102 & 353 \\
\hline 12 & Bahrain & 64 & 64 & 86 & 107 & 321 \\
\hline 13 & Korea Selatan & 63 & 35 & 51 & 55 & 204 \\
\hline 14 & Brunei Darussalam & 40 & 25 & 63 & 79 & 207 \\
\hline 15 & Mesir & 17 & 10 & 9 & 33 & 69 \\
\hline 16 & Kanada & 12 & 3 & 10 & 22 & 47 \\
\hline 17 & Turki & 6 & 3 & 15 & 15 & 39 \\
\hline 18 & Peru & 11 & 5 & 3 & 8 & 27 \\
\hline 19 & Algeria & 11 & 3 & 2 & - & 16 \\
\hline 20 & Rusia & 0 & 5 & 10 & - & 15 \\
\hline 21 & Lainnya & 118 & 114 & 118 & 208 & 558 \\
\hline & Total & 5,426 & 4,432 & 3,953 & 4,894 & 18,075 \\
\hline
\end{tabular}

Sumber: Data Penempatan dan Perlindungan TKI 2015 (BNP2TKI)

Data di atas menunjukkan Malaysia menempati posisi kedua untuk pengaduan TKI. Posisi pertama ditempati Arab Saudi. 
Tabel 4.7 Pengaduan Berdasarkan Jenis Masalah 2012-2015

\begin{tabular}{|c|c|c|c|c|c|c|}
\hline \multirow{2}{*}{ No. } & \multirow{2}{*}{ Jenis Masalah } & \multicolumn{4}{|c|}{ Tahun } & \multirow{2}{*}{ Total } \\
\hline & & 2012 & 2013 & 2014 & 2015 & \\
\hline 1 & TKI Ingin Dipulangkan & 1,030 & 1,055 & 818 & 524 & 3,427 \\
\hline 2 & Gaji tidak dibayar & 898 & 666 & 514 & 488 & 2,566 \\
\hline 3 & Putus Hubungan Komunikasi & 636 & 527 & 359 & 287 & 1,809 \\
\hline 4 & $\begin{array}{l}\text { Meninggal dunia di negara } \\
\text { tujuan }\end{array}$ & 550 & 363 & 496 & 680 & 2,089 \\
\hline 5 & Pekerjaan tidak sesuai PK & 622 & 329 & 234 & 171 & 1,356 \\
\hline 6 & TKI sakit/rawat inap & 227 & 196 & 175 & 244 & 842 \\
\hline 7 & $\begin{array}{l}\text { Tindak kekerasan dari } \\
\text { majikan }\end{array}$ & 206 & 120 & 105 & 104 & 537 \\
\hline 8 & $\begin{array}{l}\text { Pemutusan hubungan kerja } \\
\text { sebelum masa perjanjian } \\
\text { kerja berakhir }\end{array}$ & 147 & 147 & 90 & 167 & 551 \\
\hline 9 & TKI gagal berangkat & 84 & 96 & 136 & 658 & 974 \\
\hline 10 & TKI mengalami kecelakaan & 97 & 89 & 93 & 95 & 374 \\
\hline 11 & TKI tidak berdokumen & 30 & 120 & 73 & 81 & 304 \\
\hline 12 & $\begin{array}{l}\text { TKI dalam tahanan/proses } \\
\text { tahanan }\end{array}$ & 97 & 60 & 63 & 46 & 266 \\
\hline 13 & $\begin{array}{l}\text { Penahanan paspor atau } \\
\text { dokumen lainnya oleh } \\
\text { PPTKIS }\end{array}$ & 88 & 56 & 50 & 39 & 233 \\
\hline 14 & Ilegal Rekrut calon TKI & 31 & 37 & 110 & 37 & 215 \\
\hline 15 & Sakit & 45 & 64 & 38 & 38 & 185 \\
\hline 16 & Lari dari majikan (Saudi) & 60 & 44 & 41 & 38 & 183 \\
\hline 17 & $\begin{array}{l}\text { TKI tidak harmonis dengan } \\
\text { pengguna }\end{array}$ & 40 & 45 & 47 & - & 132 \\
\hline 18 & $\begin{array}{l}\text { Potongan gaji melebihi } \\
\text { ketentuan }\end{array}$ & 60 & 38 & 33 & 34 & 165 \\
\hline 19 & Meninggal & 55 & 48 & 28 & - & 131 \\
\hline 20 & Pelecehan seksual & 68 & 40 & 22 & - & 130 \\
\hline 21 & Lainnya & 355 & 292 & 428 & 1,163 & 2,238 \\
\hline & Total & 5,426 & 4,432 & 3,953 & 4,894 & 18,705 \\
\hline
\end{tabular}

Sumber: Data Penempatan dan Perlindungan TKI 2015 (BNP2TKI)

Data di atas menunjukkan masalah yang dihadapi TKI dengan jumlah pengaduan tertinggi adalah TKI ingin dipulangkan, disusul gaji tidak dibayar dan posisi ketiga putus hubungan komunikasi. 


\subsection{Struktur Undang-Undang No. 39 Tahun 2004}

Undang-Undang Nomor 39 Tahun 2004 terdiri dari 16 Bab dengan 109 Pasal.

a. Bab I Ketentuan Umum (Pasal 1-4)

b. Bab II Tugas, Tanggung Jawab dan Kewajiban Pemerintah (Pasal 5-7)

c. Bab III Hak dan Kewajiban TKI (Pasal 8-9)

d. Bab IV Pelaksanaan Penempatan TKI di Luar Negeri (Pasal 1026)

e. Bab V Tata Cara Penempatan

i. Bagian Pertama: Umum (Pasal 27-30)

ii. Bagian Kedua: Pra-Penempatan TKI (Pasal 31)

1. Paragraf 1: Surat Izin Pengerahan (Pasal 32)

2. Paragraf 2: Perekrutan dan Seleksi (Pasal 34-40)

3. Paragraf 3: Pendidikan dan Pelatihan Kerja (Pasal 41-47)

4. Paragraf 4: Pemeriksaan Kesehatan dan Psikologi (Pasal 48-50)

5. Paragraf 5: Pengurusan Dokumen (Pasal 51-54)

iii. Bagian Ketiga: Perjanjian Kerja (Pasal 55-69)

iv. Bagian Keempat: Masa Tunggu di Penampungan (Pasal 70)

v. Bagian Kelima: Masa Penempatan (Pasal 71-72)

vi. Bagian Keenam: Purna Penempatan (Pasal 73-75) 
vii. Bagian Ketujuh: Pembiayaan (Pasal 76)

f. Bab VI Perlindungan TKI (Pasal 77-84)

g. Bab VII Penyelesaian Perselisihan (Pasal 85)

h. Bab VIII Pembinaan (Pasal 86-91)

i. Bab IX Pengawasan (Pasal 92-93)

j. Bab X Badan Nasional Penempatan dan Perlindungan TKI (Pasal 94-99)

k. Bab XI Sanksi Administratif (Pasal 100)

I. Bab XII Penyidikan (Pasal 101)

m. Bab XIII Ketentuan Pidana (Pasal 102-104)

n. Bab XIV Ketentuan Lain-Lain (105-106)

o. Bab XV Ketentuan Peralihan (Pasal 107-108)

p. Bab XVI Ketentuan Penutup (Pasal 109) 


\section{BAB V}

\section{HASIL DAN PEMBAHASAN}

Bab ini merupakan hasil elaborasi antara tinjauan pustaka yang telah dirujuk dalam penelitian ini dengan proses pengumpulan data di lapangan. Proses elaborasi ini bertujuan untuk mempertemukan antara instrumen ekonomi politik dan pemenuhan hak-hak pekerja migran asal Sulawesi Selatan di Malaysia.

\subsection{Pemenuhan Hak-Hak Pekerja Migran asal Sulawesi Selatan pada}

\section{Masa Pra-Penempatan}

\subsubsection{Peran Pemerintah}

Pemerintah merupakan lembaga yang berperan sentral dalam pemenuhan hak-hak pekerja migran. Sebagaimana diamanatkan dalam UU No. 39 Tahun 2004 tentang Penempatan dan Perlindungan Tenaga Kerja Indonesia di Luar Negeri (PPTKILN). Pasal 5-7 menjelaskan tugas, tanggungjawab dan kewajiban pemerintah. Tugas pemerintah yakni mengatur, membina, melaksanakan, dan mengawasi penyelenggaraan penempatan dan perlindungan TKI di luar negeri. Sedangkan dalam melaksanakan tugasnya, pemerintah dapat melimpahkan sebagian wewenangnya dan/atau tugas perbantuan kepada pemerintah daerah sesuai dengan peraturan perundang-undangan. Tanggungjawab pemerintah yakni meningkatkan upaya perlindungan TKI di luar negeri.

Dalam menjalankan tugas dan tanggung jawab, pemerintah berkewajiban: (a) menjamin terpenuhinya hak-hak calon TKI/TKI, baik yang berangkat melalui pelaksana penempatan TKI, maupun yang berangkat secara mandiri; (b) mengawasi pelaksanaan penempatan calon 
TKI; (c) membentuk dan mengembangkan sistem informasi penempatan calon TKI di luar negeri; (d) melakukan upaya diplomatik untuk menjamin pemenuhan hak dan perlindungan TKI secara optimal di negara tujuan; dan (e) memberikan perlindungan kepada TKI selama masa sebelum pemberangkatan, masa penempatan, dan masa purna penempatan.

Pemerintah telah memulai perannya saat dokumen job order/demand letter dikaji dan disetujui oleh perwakilan Republik Indonesia di negara tujuan. Konsulat Republik Indonesia di Tawau yang menerima pengajuan dokumen demand letter dari pengguna/majikan menerapkan sejumlah persyaratan untuk memberikan persetujuan. Prakoso Wicaksono, Fungsi Ekonomi dan Protokol Kekonsuleran KRI Tawau menjelaskan:

"Selain demand letter, konsul juga mensyaratkan dokumendokumen untuk diperiksa. Konsul juga mengecek apakah majikan di Malaysia maupun PPTKIS di Sulsel ada masalah yang belum diselesaikan" ${ }^{1}$

Dokumen-dokumen yang dibutuhkan dijelaskan lebih lanjut dalam Buku Tugas Pokok dan Fungsi Konsulat Republik Indonesia Tawau yang diberikan oleh informan. Dalam buku tersebut dijelaskan ada 12 dokumen yang dipersyaratkan untuk pelayanan rekrutmen TKI (demand letter) antara lain: (1) surat permohonan dari perusahaan pengguna TKI; (2) surat permohonan dari agensi pekerjaan di Sabah; (3) surat permohonan dari PPTKIS di Indonesia; (4) surat penunjukan agensi pekerjaan dan PPTKIS dari perusahaan pengguna TKI; (5) draf perjanjian kerja antara perusahaan pengguna dengan TKI; (6) perjanjian kerjasama penempatan

\footnotetext{
${ }^{1}$ Wawancara dengan Prakoso Wicaksono, Fungsi Ekonomi dan Protokol Kekonsuleran/Vice Consul KRI Tawau, 24 Mei 2016 di Kantor KRI Tawau.
} 
antara agensi pekerjaan di Sabah dengan PPTKIS di Indonesia; (7) fotokopi kelulusan menjamin pekerja (kuota yang dikeluarkan oleh Imigrasi di Sabah); (8) profil perusahaan pengguna TKI (izin pendirian perusahaan dII); (9) fotokopi SIUP PPTKIS; (10) fotokopi izin usaha dari Agensi Pekerjaan di Sabah; (11) formulir permohonan perekrutan TKI (demand letter); dan (12) struktur penggajian TKI.

Pengesahan demand letter dalam dua tahun terakhir (2014 dan 2015) secara kumulatif mengalami peningkatan dari 1.382 permohonan di tahun 2014 menjadi 2.375 di tahun 2015. Selengkapnya pada tabel:

Tabel 5.1 Pengesahan Demand Letter Tahun 2014 dan 2015

\begin{tabular}{|l|l|c|c|}
\hline No & \multicolumn{1}{|c|}{ Sektor } & Tahun 2014 & Tahun 2015 \\
\hline 1 & Perladangan & 982 & 2.295 \\
\hline 2 & Pabrik/Manufaktur & 400 & 80 \\
\hline 3 & Konstruksi & 0 & 0 \\
\hline 4 & Servis/Jasa & 0 & 0 \\
\hline \multicolumn{2}{|l}{ Jumlah } & 1.382 & 2.375 \\
\hline
\end{tabular}

Sumber: LKj Konsulat RI Tawau TA 2015

Data di atas menunjukkan permintaan untuk pekerja sektor perladangan mengalami peningkatan signifikan dibanding tahun 2014, yaitu dari 982 pada tahun 2014 menjadi 2.295 pada tahun 2015, naik 1.313 permohonan. Namun terjadi penurunan untuk pekerja pabrikan atau kilang dari 400 (tahun 2014) menjadi 80 (tahun 2015).

Dian Ratri Astuti, Kepala Kanselerai/Fungsi Pensosbud KRI Tawau menerangkan faktor-faktor yang menyebabkan kenaikan dan penurunan pengesahan demand letter yang diajukan kepada KRI Tawau.

"Kenaikan pekerja sektor perladangan (perkebunan) antara lain disebabkan banyaknya para tenaga kerja dari kota-kota di Sabah yang mengurus visa izin tinggal di Tawau. Sedangkan menurunnya aktivitas pabrik-pabrik atau kilang, khususnya pabrik kayu, akibat 
kekurangan bahan baku, selain itu banyak WNI/PMI pekerja pabrik beralih ke sektor perladangan. Faktor perekrutan tenaga kerja asal Bangladesh di pabrik-pabrik juga mempengaruhi penurunan (kebutuhan) tenaga kerja asal Indonesia. Di samping itu aturan upah minimum pekerja asing di Sabah sebesar RM 800 yang menjadi syarat mutlak yang wajib dipenuhi oleh perusahaan/majikan untuk mendapatkan pengesahan (endorsement) dari KRI Tawau, juga ikut mempengaruhi peningkatan tersebut" ${ }^{2}$

Pernyataan di atas memperlihatkan bahwa majikan/pengguna menjalin komunikasi yang cukup intensif dengan perwakilan RI di Tawau. Interaksi ini ini terjadi atas amanat dari UU No. 39/2004 yang mempersyaratkan demand letter. Selain itu, pernyataan KRI Tawau juga mengkonfirmasi bahwa pekerja migran Indonesia, termasuk yang berasal dari Sulawesi Selatan secara formal dibutuhkan di wilayah Sabah. Terlihat dari peningkatan permohonan demand letter pada tahun 2015 di sektor perkebunan yang mengalami kenaikan yang signifikan. Pelayanan permohonan demand letter ini sesuai dengan tugas dan fungsi pelayanan ketenagakerjaan KRI Tawau sebagai upaya perlindungan WNI/TKI.

Peran pemerintah dalam pra-penempatan lainnya yakni penerbitan Surat Izin Pengerahan (SIP) oleh BNP2TKI. Pasal 32 ayat (4) UU No. 39/2004 dinyatakan bahwa tata cara penerbitan SIP diatur lebih lanjut dengan Peraturan Menteri. Kementerian Ketenagakerjaan RI yang menaungi Direktorat Penempatan dan Perlindungan Tenaga Kerja Luar Negeri (PPTKLN) merupakan bagian yang mengurusi pekerja migran Indonesia (TKI). Direktorat ini memiliki visi yakni: terwujudnya penempatan dan perlindungan Tenaga Kerja Indonesia di luar negeri dan industri jasa

\footnotetext{
${ }^{2}$ Wawancara dengan Dian Ratri Astuti, Kepala Kanselerai/Fungsi Pensosbud KRI Tawau, 24 Mei 2016 di Kantor KRI Tawau.
} 
yang sehat menuju kesejahteraan masyarakat dan misi: (1) menciptakan ketentuan hukum dalam lingkup penempatan dan perlindungan TKI; (2) melakukan kerjasama bilateral dan multilateral dalam peningkatan penempatan dan perlindungan TKI; (3) meningkatkan profesionalisme pelaksanaan penempatan TKI (PPTKIS) dan lembaga penunjang lainnya; (4) memberikan pelayanan kepada masyarakat yang mudah,murah, dan cepat; (5) memperkecil penempatan TKI non-prosedural melalui peningkatan sosialisasi dan koordinasi lintas sektor; (6) meningkatkan promosi dan peluang pasar kerja luar negeri sektor formal; dan (7) meningkatkan efisiensi dan efektifitas pasar kerja. ${ }^{3}$

Pasal 3 Permenaker No. 22 Tahun 2014 menyatakan bahwa untuk memperoleh SIP, PPTKIS harus mengajukan permohonan secara tertulis kepada Kepala BNP2TKI dengan melampirkan dokumen: (a) copy perjanjian kerja sama penempatan; (b) surat permintaan TKI dari pengguna/job order/demand letter/wakalah; (c) rancangan perjanjian kerja; dan (d) rancangan perjanjian penempatan. Dokumen poin $a, b$ dan $c$ tersebut dibuat dalam dua bahasa yaitu bahasa Indonesia dan bahasa negara penempatan, serta telah mendapat persetujuan dari Perwakilan Republik Indonesia di negara penempatan atau KDEI. Dokumen ini jika telah dinyatakan lengkap dan sah sesuai dengan peraturan perundangundangan dengan memperhatikan rencana kerja penempatan yang telah disetujui, maka Surat Izin Pengerahan (SIP) dapat diterbitkan. SIP memuat: (a) nomor dan tanggal surat permintaan TKI; (b) nama calon

\footnotetext{
${ }^{3}$ Direktorat Jenderal Binapenta dan PKK Kemenaker RI, n.d., Direktorat Penempatan dan Perlindungan Tenaga Kerja Luar Negeri (PPTKLN) -

http://binapenta.naker.go.id/page/direktorat-pptkln, diakses 11 Juli 2016.
} 
mitra usaha atau pengguna di negara penempatan; (c) jumlah calon TKI yang akan direkrut pada provinsi yang bersangkutan; (d) jenis pekerjaan/jabatan serta syarat-syarat dan kondisi kerja; (e) jangka waktu berlakunya SIP; dan (f) daerah rekrut.

Penerbitan SIP merupakan kewenangan Badan Nasional Penempatan dan Perlindungan Tenaga Kerja Indonesia (BNP2TKI) yang merupakan lembaga pemerintah yang mengkoordinasikan penempatan dan perlindungan TKI di luar negeri dan berkedudukan di Ibukota negara dan Balai Pelayanan Penempatan dan Perlindungan Tenaga Kerja Indonesia (BP3TKI) di Ibukota Provinsi. BNP2TKI dibentuk berdasarkan UU No. 39 Tahun 2004 Pasal 95 ayat 1 yang menyatakan bahwa badan ini merupakan lembaga pemerintah non-departemen yang bertanggungjawab kepada Presiden yang berkedudukan di Ibukota negara. Lembaga ini dibentuk berdasarkan Peraturan Presiden No. 81 Tahun 2006 tentang BNP2TKI.

Tahap selanjutnya yakni PPTKIS yang telah memperoleh SIP, melaporkan pada dinas provinsi daerah rekrut untuk memperoleh Surat Pengantar Rekrut (SPR). Dinas menentukan daerah rekrut di wilayah kabupaten/kota di wilayah provinsi yang bersangkutan. Syamsi Alang, Disnakertrans Provinsi Sulsel menjelaskan tupoksi lembaganya:

"Tugas pokok dan fungsi kami di Disnakertrans Sulsel yakni melakukan pembinaan kepada PPTKIS dan mengeluarkan SPR. Surat ini dikeluarkan setelah melakukan pengkajian terhadap data yang telah kami kumpulkan dari Disnaker kabupaten/kota di Sulsel 
untuk memformulasikan kabupaten/kota yang menjadi daerah rekrut PPTKIS" 4

Penjelasan mengenai tupoksi di atas telah sesuai dengan tugas yang diberikan kepada Dinas Provinsi dalam UU No. 39/2004 yang diturunkan dalam Permenaker No. 22 Tahun 2014. Pasal 9 dalam peraturan tersebut menyatakan bahwa PPTKIS yang telah memperoleh SIP, melaporkan pada dinas provinsi daerah rekrut dan BP3TKI untuk memperoleh surat pengantar rekrut.

Pemerintah kabupaten/kota di Sulawesi Selatan yang menjadi lokasi penelitian yakni Kota Makassar, Kabupaten Gowa dan Kota ParePare memberikan respon yang berbeda-beda terhadap tupoksi yang dijalankan. Andi Iskandar, Dinas Tenaga Kerja Kota Makassar memberi tanggapan:

"Disnaker kota Makassar melaksanakan dua tugas yakni rekrutmen dan seleksi juga rekom passport. Tahun 2013 kami melakukan seleksi ketat terhadap 10 orang. Menanggapi rendahnya minat warga Makassar menjadi TKI, karena pertumbuhan ekonomi sudah tinggi dan investasi di Makassar yang sudah cukup bagus. Sehingga orang lebih memilih bekerja di dalam negeri daripada bekerja di luar negeri yang dianggap lebih beresiko" 5

Tanggapan dari informan di atas menunjukkan bahwa Disnaker Kota Makassar mengetahui tupoksi yang diberikan. Namun demikian bergeraknya ekonomi di Makassar memberikan pengaruh terhadap minat warga Makassar untuk menjadi TKI.

\footnotetext{
${ }^{4}$ Wawancara dengan Dr. Syamsi Alang, M.M., Koordinator Fungsional Pengantar Kerja Dinas Tenaga Kerja dan Transmigrasi Provinsi Sulawesi Selatan, 4 April 2016 di Kantor Disnakertrans Prov. Sulsel, Makassar.

${ }^{5}$ Wawancara dengan Andi Iskandar, Kepala Seksi Perluasan Kerja, Dinas Tenaga Kerja Kota Makassar, 29 Maret 2016 di Kantor Disnaker Kota Makassar.
} 
Kabupaten Gowa merupakan daerah dengan penempatan TKI terbesar dari Sulawesi Selatan. Mustamin Raga, Kepala Bidang Tenaga Kerja, Disnakersostrans Gowa memberi tanggapan:

"Tugas pokok dan fungsi dinas kabupaten/kota memang tidak terlalu detil disebutkan dalam UU No. 39 Tahun 2004 tetapi lebih spesifik dijelaskan tugasnya dalam Peraturan Menteri Tenaga Kerja dan Transmigrasi Nomor Per.14/Men/X/2010 tentang Pelaksanaan Penempatan dan Perlindungan Tenaga Kerja Indonesia di Luar Negeri. Dalam peraturan ini sudah dijelaskan bahwa sebelum dilakukan keberangkatan banyak hal yang dilakukan seperti: sosialisasi, seleksi, rekrutmen, pendaftaran sampai rekomendasi paspor. Sampai di tahap ini tanggungjawab dinas sudah selesai. Kami aktif dan tertib memantau SISKOTKLN agar mengetahui perkembangan TKI yang berasal dari Gowa" 6

Pernyataan dari informan di atas secara tersirat menunjukkan

bahwa informan paham dengan peraturan perundang-undangan dan peraturan teknis yang mengatur keterlibatan pemerintah daerah dalam menangani pekerja migran. Perhatian yang diberikan oleh Kabupaten Gowa juga cukup serius terhadap $\mathrm{TKI}$, sehingga berpengaruh positif dengan angka penempatan yang tinggi.

Kota Pare-Pare merupakan kota pemberangkatan (embarkasi) TKI ke Sabah Malaysia. Yusran, Kepala Bidang Penempatan Tenaga Kerja Dinas Tenaga Kerja Kota Pare-Pare menanggapi:

"Kegiatan yang melibatkan Disnaker sudah dilaksanakan dengan baik. Tanggungjawab Disnaker Gowa meliputi penerimaan pendaftaran dan pemberian rekomendasi paspor. Hal yang ditekankan oleh Disnaker Pare-Pare bahwa pihak Imigrasi di ParePare tidak akan memberikan paspor kepada CTKI apabila tidak memiliki rekomendasi dari Disnaker"

\footnotetext{
${ }^{6}$ Wawancara dengan Mustamin Raga, Disnakersostrans Kabupaten Gowa, 22 April 2016 di Kompleks Kantor Bupati Gowa.

${ }^{7}$ Wawancara dengan Yusran, S.Pd., Kepala Bidang Penempatan Tenaga Kerja, Disnaker Kota Pare-Pare, 31 Maret 2016 di Kantor Disnaker Kota Pare-Pare.
} 
Pernyataan di atas menunjukkan ketegasan Disnaker Kota ParePare. Hal yang perlu diantisipasi CTKI yang ingin bekerja di luar negeri, namun tidak mendapatkan rekomendasi paspor dapat mengajukan paspor di Kantor Imigrasi Makassar. Sehingga penerapan aturan tersebut sulit dilakukan tetapi patut diapresiasi.

Menanggapi interaksi antar pemerintah daerah di Sulawesi Selatan. Gubernur Sulawesi Selatan, Dr. Syahrul Yasin Limpo menyatakan bahwa koordinasi kelembagaan memegang peranan penting dalam penempatan pekerja migran asal sulawesi selatan

“... yang paling memang direncanakan adalah bagaimana mengkoordinasikan secara kelembagaan program-program (penempatan dan perlindungan) tersebut baik dalam negeri maupun luar negeri. Dan setelah itu barulah kita berharap ada tuntutan-tuntunan yang kuat dari key position yang ada di dalam negeri maupun di luar negeri. Jadi memang ada orang-orang yang kita titipkan sebagai liaison officer baik dalam negeri maupun luar negeri yang dipersiapkan dengan baik agar tidak bias program. Artinya lain yang kita persiapkan, lain yang terjadi. Barulah kemudian memberangkatkan tenaga kerja kita"

Pernyataan di atas menunjukkan komitmen pemerintah provinsi Sulawesi Selatan untuk turut terlibat dalam proses penempatan dan perlindungan pekerja migran asal Sulawesi Selatan. Tetapi peran pemerintah daerah masih sangat terbatas dalam UU No. 39/2004 sehingga perlu diperkuat.

Pemaparan mengenai keterlibatan pemerintah daerah secara normatif telah diatur dalam turunan UU No. 39/2004 dalam Peraturan Menteri Tenaga Kerja dan Transmigrasi Republik Indonesia No. Per.14/Men/X/2010 tentang Pelaksanaan Penempatan dan Perlindungan

\footnotetext{
${ }^{8}$ Wawancara dengan Dr. Syahrul Yasin Limpo, S.H., M.H., M.Si., Gubernur Sulawesi Selatan, 20 Mei 2016 di Jakarta,
} 
Tenaga Kerja Indonesia di Luar Negeri. Beberapa bagian yang menyebutkan frasa dinas provinsi dan/atau dinas kabupaten/kota dalam peraturan tersebut sebagai berikut:

(1) SIP (Surat Ijin Pengerahan) disampaikan kepada PPTKIS dengan tembusan pada dinas provinsi dan dinas kabupaten/kota daerah rekrut (Pasal 4);

(2) PPTKIS yang telah memperoleh SIP, melaporkan pada dinas provinsi daerah rekrut dan BP3TKI untuk memperoleh surat pengantar rekrut (Pasal 9);

(3) Dinas kabupaten/kota menerbitkan berita acara hasil seleksi calon TKI berdasarkan daftar nominasi dan disampaikan pada PPTKIS dengan tembusan pada dinas provinsi dan BP3TKI. Berdasarkan Berita Acara tersebut dinas kabupaten/kota mengeluarkan rekomendasi penerbitan paspor TKI (Pasal 19);

(4) Perjanjian Kerja ditandatangani calon TKI pada saat mengikuti PAP (Pembekalan Akhir Pemberangkatan) dihadapan pejabat dinas provinsi atau dinas kabupaten/kota (Pasal 27);

(5) Program PAP diselenggarakan oleh BP3TKI dan difasilitasi oleh dinas provinsi (Pasal 32);

(6) Dinas provinsi mengkoordinasikan BP3TKI, dinas kabupaten/kota dan instansi pemerintah terkait dalam memberikan pelayanan penempatan dan perlindungan TKI sesuai tugas masing-masing (Pasal 42); 
(7) Guna memberikan pelayanan terbaik penempatan dan perlindungan TKI, Gubernur sebagai wakil Pemerintah, dapat menyelenggarakan layanan satu atap sesuai dengan peraturan perundang-undangan. Lebih lanjut, koordinasi pelaksanaan layanan satu atap dilakukan oleh gubernur sebagai wakil Pemerintah dengan melibatkan BP3TKI, dinas provinsi, dinas kabupaten/kota, dan instansi pemerintah terkait sesuai tugas masing-masing (Pasal 43-44).

Peraturan di atas telah mengalami revisi menjadi Peraturan Menteri Ketenagakerjaan No. 22 Tahun 2014 tentang Pelaksanaan Penempatan dan Perlindungan Tenaga Kerja Indonesia di Luar Negeri. Setelah melakukan perbandingan dengan peraturan yang lama, tidak ditemukan adanya perbedaan yang signifikan dengan peraturan yang sudah direvisi. Sehingga tugas pemerintah provinsi dan kabupaten/kota yang telah diidentifikasi masih relevan.

Berdasarkan hasil pengkajian di atas, maka dapat dipahami bahwa ada beberapa tugas yang diamanatkan kepada pemerintah daerah provinsi maupun kabupaten/kota yakni: penerbitan surat pengantar rekrut (SPR) oleh dinas provinsi, penerbitan rekomendasi paspor oleh dinas kabupaten/kota, penandatanganan perjanjian kerja oleh calon TKI dihadapan pejabat dinas provinsi atau kabupaten/kota, koordinasi yang dipimpin oleh dinas provinsi dengan BP3TKI dan dinas kabupaten/kota, dan peluang bagi Gubernur untuk menginisiasi layanan satu atap untuk memberikan pelayanan terbaik bagi TKI. Pengaturan penempatan dan 
perlindungan Tenaga Kerja Indonesia di luar negeri dalam peraturan ini merupakan norma, standar, prosedur, dan kriteria yang telah disesuaikan dengan Peraturan Pemerintah Republik Indonesia No. 38 Tahun 2007 tentang Pembagian Urusan Pemerintahan Antara Pemerintah, Pemerintahan Daerah Provinsi dan Pemerintahan Daerah Kabupaten/Kota.

Perekonomian utamanya masalah hak-hak pekerja migran (TKI) tentu tidak bisa diserahkan sepenuhnya pada produsen (swasta) dan konsumen (majikan/pengguna) yang berinteraksi satu sama lain melalui mekanisme pasar. Campur tangan pemerintah diperlukan untuk menjadi penengah antara PPTKIS di Indonesia sebagai penyalur tenaga kerja ke luar negeri dengan majikan/pengguna di negara penempatan dalam hal ini Malaysia. Sehingga perlu diatur mekanisme penempatan dan perlindungannya dalam suatu kebijakan publik (UU No.39 Tahun 2004).

Bagan 5.1 Hierarki Kebijakan Publik dalam Pemenuhan Hak-Hak Pekerja Migran Indonesia Masa Pra-Penempatan

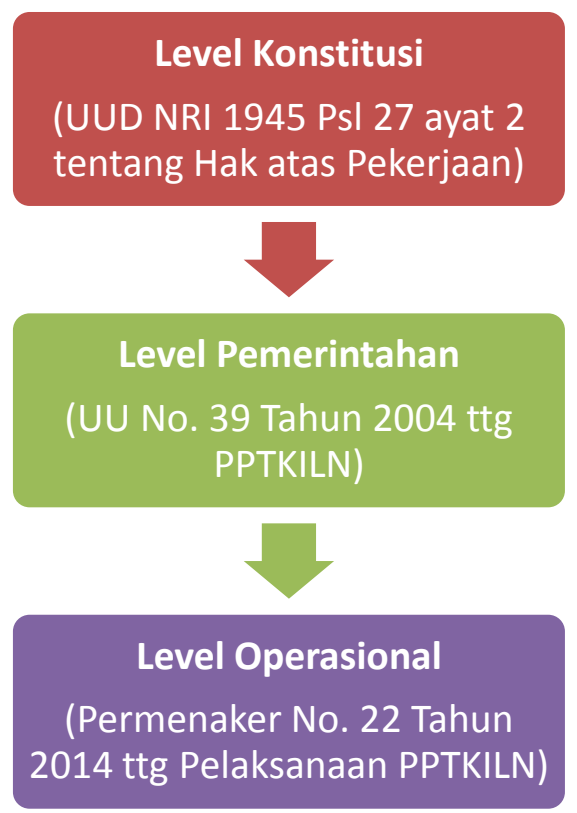


Model hierarki kebijakan publik merupakan salah satu model yang sering digunakan dalam analisis ekonomi politik. Dalam model hierarki kebijakan publik ada tiga lapis kelembagaan yaitu: (1) level konstitusi; (2) level pemerintah dan (3) level operasional. Jika digunakan dalam konteks pemenuhan hak-hak pekerja migran asal Sulawesi Selatan pada masa pra-penempatan, maka tiga tingkat hierarki kebijakan publik ini digambarkan pada di atas.

\subsubsection{Interaksi Pemerintah dan Swasta}

Pelaksana Penempatan Tenaga Kerja Indonesia Swasta (PPTKIS) merupakan bagian dari pelaksana penempatan TKI di luar negeri bersama-sama dengan pemerintah (Pasal 10 UU No. 39/2004) Namun demikian, perusahaan pelaksana penempatan TKI swasta wajib mendapat izin tertulis berupa Surat Izin Pelaksana Penempatan TKI (SIPPTKI). Dalam rangka memperoleh izin tersebut, PPTKIS diharuskan memenuhi persyaratan: (a) berbentuk badan hukum perseroan terbatas (PT) yang didirikan berdasarkan peraturan perundang-undangan; (b) memiliki modal disetor yang tercantum dalam akta pendirian perusahaan, sekurangkurangnya sebesar Rp. 3.000.000.000 (tiga milyar rupiah); (c) menyetor uang kepada bank sebagai jaminan dalam bentuk deposito sebesar Rp. 15.000.000 (lima belas juta rupiah) pada bank pemerintah; (d) memiliki rencana kerja penempatan dan perlindungan TKI di luar negeri sekurangkurangnya untuk kurun waktu 3 (tiga) tahun berjalan; (e) memiliki unit pelatihan kerja; dan (f) memiliki sarana dan prasarana pelayanan penempatan TKI. 
Selanjutnya, tanggungjawab PPTKIS yang berkaitan dengan penempatan dan perlindungan TKI, antara lain:

1) Bertanggung jawab kepada TKI yang ditempatkan sejak dari daerah asal sampai kembali ke daerah asal.

2) Untuk melakukan rekrut calon $\mathrm{TKI}$, harus mempunyai surat permintaan tenaga kerja dari pengguna di luar negeri (job order).

3) Calon TKI yang direkrut oleh PPTKIS harus mempunyai :

a. Perjanjian Penempatan; perjanjian penempatan antara TKI dan PPTKIS untuk menjamin kepastian keberangkatan calon TKI serta hak dan kewajiban masing-masing pihak.

b. Perjanjian Kerja; perjanjian antara TKI dan pengguna untuk menetapkan hak dan kewajiban TKI dan pengguna di luar negeri.

4) PPTKIS wajib memberangkatkan calon TKI selambat-lambatnya 3 (tiga) bulan sejak diterbitkannya Kartu Identitas Tenaga Kerja Indonesia (KI TKI/KTKLN)

5) Sebagai upaya pembinaan PPTKIS dan perlindungan calon TKI serta TKI. Dirjen atas nama Menteri Tenaga Kerja dapat menjatuhkan sanksi: (a) teguran tertulis; (b) penghentian kegiatan sementara (skorsing); (c) pencabutan SIUP-PPTKIS.

6) Dalam hal PPTKIS dicabut SIUP-PPTKIS-nya maka PPTKIS wajib melakukan:

a. Mengembalikan seluruh biaya yang telah diterima; 
b. Memberangkatkan calon TKI yang telah memiliki dokumen pemberangkatan;

c. Menyelesaikan permasalahan yang dialami TKI;

d. Deposito jaminan dapat dicairkan setelah 2 tahun TKI diberangkatkan terakhir.

7) Dalam hal calon TKI tidak memenuhi perjanjian penempatan TKI, calon TKI harus mengembalikan seluruh biaya yang dikeluarkan oleh PPTKIS. ${ }^{9}$

Sedangkan, hak yang dimiliki oleh PPTKIS, antara lain: (1) berhak mendapatkan pelayanan berdasarkan ketentuan yang berlaku dalam penempatan tenaga kerja ke luar negeri; (2) berhak mendapatkan informasi yang berkaitan dengan penempatan tenaga kerja ke luar negeri. Sedangkan kewajiban PPTKIS, yakni: (1) menempatkan dan melindungi TKI serta bertanggung jawab mulai sejak pemberangkatan sampai dengan kepulangan ke daerah asal TKI; (2) Menyelesaikan masalah dan (3) membuat laporan hal-hal yang terkait dengan penempatan TKI. ${ }^{10}$

BNP2TKI mencatat bahwa PPTKIS tahun 2015 yang berpusat di provinsi Sulawesi Selatan yakni PT. Bagoes Bersaudara di Makassar dengan negara penempatan: (a) Saudi Arabia; (b) UEA; (c) Oman; (d) Malaysia dan (e) Brunei Darussalam. PPTKIS ini membuka cabang di Mataram, Lombok Barat, Lombok Timur, Sumbawa dan Kupang. Selanjutnya, PT. Trimulti Citrabahari di Makassar dengan negara

9 LPK Korindo, (2012), Apa itu PPTKIS? Mari mengenal lebih jauh PPTKIS http://www.lpkkorindo.com/2012/07/apa-itu-pptkismari-mengenal-lebih-jauh.html, diakses 11 Juli 2016.

${ }^{10} \mathrm{Ibid}$. 
penempatan Jepang. ${ }^{11}$ Lebih spesifik, BP3TKI Makassar mencatat sebanyak 33 PPTKIS terdaftar di provinsi Sulawesi Selatan yang memiliki job order tahun 2015. Selengkapnya dipaparkan sebagai berikut:

Tabel 5.2 Daftar PPTKIS/Cabang di Prov. Sulawesi Selatan Tahun 2015

\begin{tabular}{|c|c|c|}
\hline No & Nama PPTKIS/Cabang & Alamat Kantor Pusat/Cabang \\
\hline \multirow{2}{*}{1} & PT. Anugrah Usaha Jaya & Jl. Siliwalan Tengah No. 88 Surabaya \\
\hline & Cabang Makassar & Jl. Toddopuli 2 Stp. 4 No. 4, Makassar \\
\hline \multirow{2}{*}{2} & PT. Arwana Citra Lestari & JI. RE Martadinata, Pontianak \\
\hline & Cabang Pare-Pare & Jl. Jambu No. 27, Pare-Pare \\
\hline \multirow{2}{*}{3} & PT. Bahrindo Mahdi & Jl. Kayu Manis No. 3, Condet, Jakara Tmr \\
\hline & Cabang Pare-Pare & Jl. Bau Massepe No. 147B, Pare-Pare \\
\hline \multirow{2}{*}{4} & PT. Bagoes Bersaudara & Jl. P. Kemerdekaan Km. 13, Makassar \\
\hline & Cabang Pare-Pare & Jl. Andi Camming No. 98, Pare-Pare \\
\hline \multirow{2}{*}{5} & PT. Kurnia Bina Rizki & Jl. Anggrek No., 1, Jakarta Timur \\
\hline & Cabang Pare-Pare & Jl. Abubakar No. 281, Pare-Pare \\
\hline 6 & PT. Trimulti Citra Bahari & Jl. Letjend Mappaoddang No. 92, Makassar \\
\hline \multirow[t]{2}{*}{7} & $\begin{array}{l}\text { PT. Wahana Karya } \\
\text { Suplaindo }\end{array}$ & Komp. Pluit Mas No. 5, Jakarta Utara \\
\hline & Cabang Makassar & Jl. Baji Nyawa Lr. 2 No. 5, Makassar \\
\hline \multirow{4}{*}{8} & $\begin{array}{l}\text { PT. Sukses Mandiri } \\
\text { Utama }\end{array}$ & $\begin{array}{l}\text { Komp. Taman Bougenvil Blok A No. 18, } \\
\text { Caman Bekasi. }\end{array}$ \\
\hline & Cabang Makassar & $\begin{array}{l}\text { Jl. Perintis Kemerdekaan Griya Alam } \\
\text { Permai Ruko No. 9, Makassar }\end{array}$ \\
\hline & Cabang Gowa & $\begin{array}{l}\text { Btn Bumi Batara Gowa Blok E.9/11 Kel. } \\
\text { Tompobalang, Kec. Somba Opu, Gowa }\end{array}$ \\
\hline & Cabang Pare-Pare & $\begin{array}{l}\text { Jl. Jambu Tengah No. } 29 \text { RT 001/RW } 005 \\
\text { Kel. Labukang Kec. Ujung, Pare-Pare }\end{array}$ \\
\hline \multirow{6}{*}{9} & PT. Persada Duta Utama & $\begin{array}{l}\text { Jl. Swadaya I No. 33, Pejaten Timur, Pasar } \\
\text { Minggu, Jakarta. }\end{array}$ \\
\hline & Cabang Bulukumba & $\begin{array}{l}\text { Jl. Bontotanae Desa Bonto Raja Kec. } \\
\text { Gantarang, Bulukumba }\end{array}$ \\
\hline & Cabang Soppeng & - \\
\hline & Cabang Jeneponto & $\begin{array}{l}\text { Balombongan Kel. Tolo Utara Kec. Kelara } \\
\text { Kab. Jeneponto }\end{array}$ \\
\hline & Cabang Pare-Pare & $\begin{array}{l}\text { Jl. Lambo No. } 26 \text { RT 001/RW } 005 \text { Kel. } \\
\text { Cappagulung Kec. Bacukiki, Pare-Pare }\end{array}$ \\
\hline & Cabang Barru & - \\
\hline 10 & PT. Putra Hidayah & Jl. Otista Dalam III No. 111, Jakarta \\
\hline
\end{tabular}

11 BNP2TKI, 2016, Daftar PPTKIS Provinsi Sulawesi Selatan 2016 http://www.bnp2tki.go.id/read/11027/Daftar-PPTKIS-Provinsi-Sulawesi-Selatan2016.html, diakses 12 Juli 2016. 


\begin{tabular}{|c|c|c|}
\hline & Cabang Pinrang & Ulu Tedong Kel. Moccorowali, Kab. Pinrang \\
\hline & Cabang Pare-Pare & Jl. Lambo No. 30 A, Pare-Pare \\
\hline \multirow{2}{*}{11} & PT. Duta Sapta Perkasa & Jl. Tebet Barat III No. 19, Jakarta Selatan \\
\hline & Cabang Pinrang & Jl. Poros Polmas Pinrang \\
\hline \multirow{2}{*}{12} & PT. Arwana Citra Lestari & Jl. Apel No, 2, Pontianak, Kalbar \\
\hline & Cabang Soppeng & Jl. H. Musa No. 48, Soppeng \\
\hline \multirow{2}{*}{13} & PT. Esdema Mandiri & - \\
\hline & Cabang Pinrang & Jl. Poros Pinrang Pare \\
\hline \multirow{2}{*}{14} & PT. Dima Kurnia Abadi & - \\
\hline & Cabang Makassar & Jl. Barukang 4 No. 22, Makassar \\
\hline \multirow[t]{2}{*}{15} & $\begin{array}{l}\text { PT. Bumi Mas Citra } \\
\text { Mandiri }\end{array}$ & 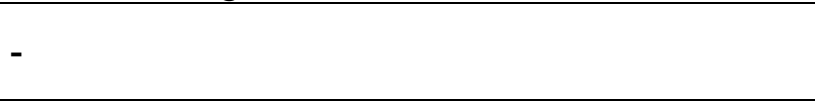 \\
\hline & Cabang Makassar & Jl. Adhyaksa I No. 11, Makassar \\
\hline \multirow{2}{*}{16} & PT. Alfatah Nur Nisa & - \\
\hline & Cabang Luwu Timur & Desa Cendana Hijau, Luwu Timur \\
\hline \multirow[t]{2}{*}{17} & $\begin{array}{l}\text { PT. Mangga Dua } \\
\text { Mahkota }\end{array}$ & $\begin{array}{l}\text { Jl. Jatiluhur Kampung Pedurenan, Jati } \\
\text { Asih, Bekasi }\end{array}$ \\
\hline & Cabang Pinrang & Jl. Briptu Suherman, Pinrang \\
\hline \multirow[t]{2}{*}{18} & $\begin{array}{l}\text { PT. Maharani Tri Utama } \\
\text { Mandiri }\end{array}$ & Jl. Pondok Serat, Pondok Aren, Bekasi \\
\hline & Cabang Bulukumba & Jl. Poros Desa Bontomacinna, Bulukumba \\
\hline \multirow[b]{2}{*}{19} & PT. Tulus Widodo Putra & Jl. R. Wijaya No. 28 A, Ponorogo, Jatim \\
\hline & Cabang Gowa & $\begin{array}{l}\text { BTN Griya Persada Manggarupi Blok B4, } \\
\text { Sungguminasa, Gowa }\end{array}$ \\
\hline \multirow[b]{2}{*}{20} & PT. Rayana Manggahina & - \\
\hline & Cabang Makassar & $\begin{array}{l}\text { Jl. Batuna Para RT 001/RW 002, } \\
\text { Kel. Baruga, Kec. Bantimurung, Maros }\end{array}$ \\
\hline \multirow[t]{2}{*}{21} & $\begin{array}{l}\text { PT. Amrita Mahesa } \\
\text { Prima }\end{array}$ & Jl. Cingsana No. 64, Gunung Putri, Bogor \\
\hline & Cabang Maros & Perum Graha Azzikrul Toha, Maros \\
\hline \multirow[t]{2}{*}{22} & $\begin{array}{l}\text { PT. Andhika Putra } \\
\text { Mandiri }\end{array}$ & $\begin{array}{l}\text { Jl. Seloaji No. 54, Ngrupit Jenangan, } \\
\text { Ponorogo }\end{array}$ \\
\hline & Cabang Gowa & $\begin{array}{l}\text { Kaledupayya Desa Taeng Kec. Palangga, } \\
\text { Kab. Gowa }\end{array}$ \\
\hline 23 & $\begin{array}{l}\text { PT. Amalindo Bhakti } \\
\text { Persada } \\
\text { (Kantor Pusat Pare-Pare) }\end{array}$ & $\begin{array}{l}\text { Jl. Mattirotasi No. } 149 \text { RT 001/RW } 004 \text {, } \\
\text { Cappa Galung, Bacukiki Barat, Pare-Pare }\end{array}$ \\
\hline \multirow{2}{*}{24} & PT. Teja Mukti Utama & Jl. Pondok Haji Raya No. 7, Bekasi \\
\hline & Cabang Gowa & BTN Restika indah Blok A No. 17, Gowa \\
\hline \multirow[b]{2}{*}{25} & PT. Bina Adidaya Mandiri & Jl. Masjid IV No. 3, Jatiwaringin, Bekasi \\
\hline & Cabang Makassar & $\begin{array}{l}\text { Bumi Tamalanrea Permai (BTP) Blok E } \\
\text { No. 159, Makassar }\end{array}$ \\
\hline
\end{tabular}

Sumber: Diolah dari data BP3TKI Makassar 
Data di atas menunjukkan bahwa mayoritas PPTKIS yang beroperasi di provinsi Sulawesi Selatan merupakan PPTKIS yang berasal dari luar provinsi Sulsel, seperti: Jakarta (6 PPTKIS), Bekasi (4 PPTKIS), Pontianak (2 PPTKIS), Ponorogo (2 PPTKIS), Surabaya (1 PPTKIS), Bogor (1 PPTKIS) dan yang tidak diketahui (5 PPTKIS). Sedangkan PPTKIS yang kantor pusatnya berada di provinsi Sulawesi Selatan hanya 3 PPTKIS yakni 2 PPTKIS di Makassar dan 1 PPTKIS di Pare-Pare.

PPTKIS yang membuka cabang di provinsi Sulawesi Selatan tersebar 10 kabupaten/kota di Sulsel, antara lain: Kota Makassar (7 PPTKIS), Kota Pare-Pare (7 PPTKIS), Kabupaten Gowa (4 PPTKIS), Kabupaten Pinrang (4 PPTKIS), Kabupaten Bulukumba (2 PPTKIS), Kabupaten Soppeng (2 PPTKIS), Kabupaten Jeneponto (1 PPTKIS), Kabupaten Barru (1 PPTKIS), Kabupaten Luwu Timur (1 PPTKIS) dan Kabupaten Maros (1 PPTKIS).

Penelitian ini memfokuskan pada salah satu PPTKIS yang berkantor pusat di Pare-Pare yakni PT. Amalindo Bhakti Persada. Penentuan PPTKIS ini dengan mempertimbangkan rekomendasi dari BP3TKI Makassar dan P4TKI Pare-Pare serta akses terhadap sumber data. Interaksi PT. Amalindo sebagai pihak swasta dengan pemerintah melalui kewajibannya mematuhi kebijakan pemerintah.

Interaksi pertama diawali PT. Amalindo saat menyediakan informasi yang dibutuhkan bagi majikan/pengguna di negara penempatan terkait job order atau demand letter yang merupakan dokumen yang harus dipersiapkan. Andi Nagauleng, Direktur PT. Amalindo Bhakti Persada, Pare-Pare menjelaskan:

"Jadi, kami memberitahukan kepada majikan/pengguna yang akan mempekerjakan TKI di Sabah kalau ada surat yang harus mereka (majikan/pengguna) buat. Intinya ada jumlah pekerja yang mereka perlukan, umur, jenis kelamin dan minimum pendidikan pekerjanya. 
Disebutkan juga nama dan alamat lengkap majikan dan PPTKISku. Ada juga masa kontrak, gaji dan fasilitas yang disediakan oleh mereka. Hal yang paling penting itu biaya yang ditanggung mereka, karena terkait dengan biayanya TKI"12

Pernyataan di atas merupakan salah satu indikator bahwa PPTKIS mengikuti ketentuan pemerintah yang mensyaratkan demand letter yang dibuat oleh majikan/pengguna. Demand letter dalam dokumen majikan/pengguna mencantumkan komponen meliputi: (1) dokumen persetujuan/kelulusan yang berisi jenis pekerjaan, jumlah pekerja yang diperlukan, umur, jenis kelamin, pendidikan dan batas waktu ketibaan TKI di Sabah Malaysia; (2) nama dan alamat lengkap majikan, PPTKIS dan agensi; (3) kemudahan dan syarat-syarat bekerja meliputi: masa kontrak kerja, waktu kerja, sistem gaji//upah, waktu pembayaran gaji/upah, kerja lembur, uang kematian, peralatan kerja, tunjangan pengangkutan, perumahan, insentif, fasilitas kesehatan, tunjangan lain-lain, serta tiket ketibaan dan kepulangan; (4) lokasi kerja TKI di Sabah Malaysia; (5) daftar kos pemasukan tahun pertama dan (6) lain-lain yang berisi: biaya rekrutmen yang dtinggung sepenuhnya oleh pengguna/majikan, sistem penggajian; masa percobaan dan ketentuan jika TKI tidak fit. (Dokumen demand letter pada Lampiran 1)

Interaksi antara PT. Amalindo berikutnya yakni penerbitan SIP oleh BNP2TKI, salah satu contohnya sebagai berikut:

\footnotetext{
${ }^{12}$ Wawancara dengan Andi Nagauleng, S.E., Direktur Utama PT. Amalindo Bhakti Persada, 24 Maret 2016 di Pare-Pare.
} 
Gambar 5.1 Surat Izin Pengerahan dari BNP2TKI

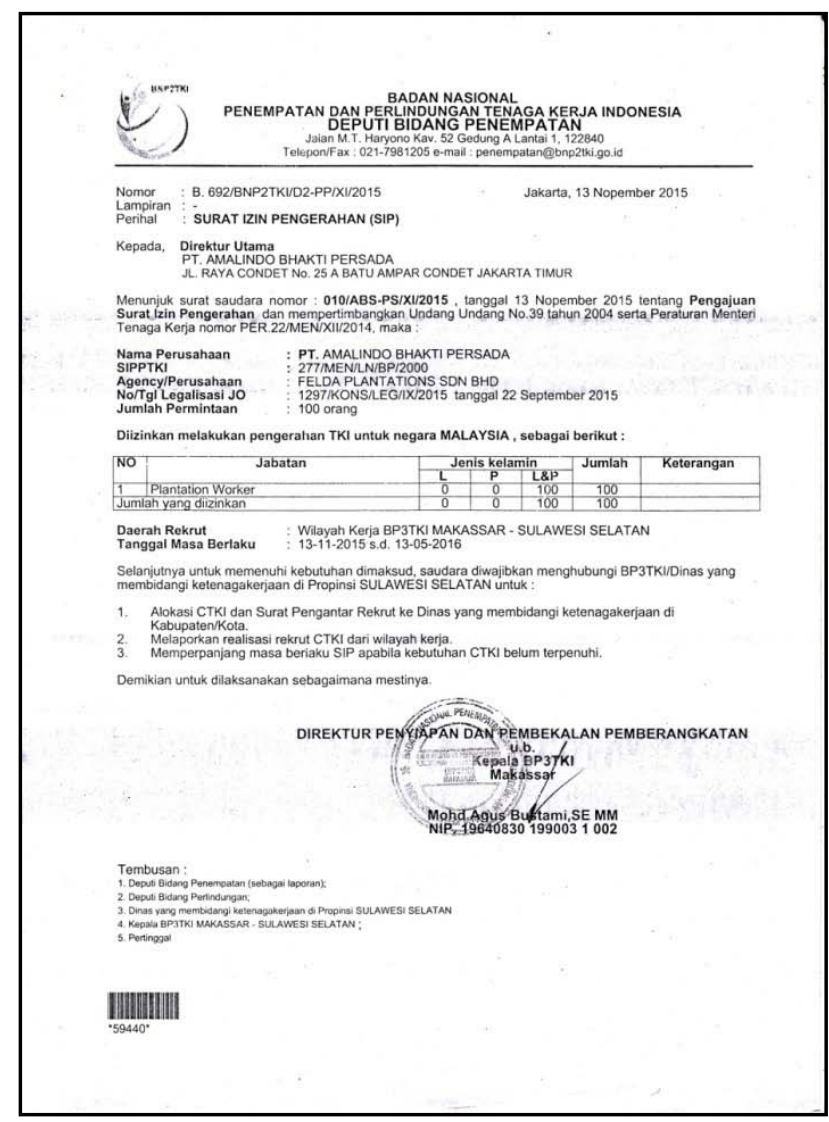

sumber: Dokumen PT. Amalindo Bhakti Persada

Andi Nagauleng, Direktur PT. Amalindo Bhakti Persada membenarkan prosedur di atas perlu ditempuh oleh PPTKIS. Ia menjelaskan bahwa SIP merupakan prasyarat untuk merekrut TKI/PMI. Dokumen ini menandakan bahwa perekrutan yang dilakukan oleh kami (PPTKIS) sesuai dengan prosedur.

"Setelah berkas yang sudah disetujui perwakilan Indonesia di Tawau diterima oleh majikan, kami dikirimkan rangkap berkasnya. Setelah itu kami cocokkan lagi dengan berkas yang dibutuhkan supaya dapat surat izin untuk merekrut (SIP) dari BNP2TKI. Contohnya dokumen SIP yang sudah dikeluarkan BNP2TKI kepada kami untuk merekrut TKI sebanyak 100 orang dengan jabatan sebagai pekerja perkebunan dengan pengguna Felda Plantations Sdn. Bhd."13

${ }^{13}$ Ibid. 
Pernyataan di atas menjelaskan bahwa PPTKIS tersebut mengikuti prosedur yang telah ditetapkan oleh UU No.39/2004 sehingga memperoleh legitimasi untuk merekrut TKI. Dokumen tersebut berfungsi sebagai kontrol bagi PPTKIS yakni membatasi jumlah TKI yang direkrut dan masa berlaku izin yang telah diberikan. (Dokumen SIP selengkapnya pada Lampiran 2)

Setelah itu dilanjutkan dengan pengurusan SPR yang diterbitkan oleh Dinas Tenaga Kerja dan Transmigrasi Provinsi Sulawesi Selatan.

Gambar 5.2 Surat Pengantar Rekrut (SPR) dari Disnakertrans Sulsel

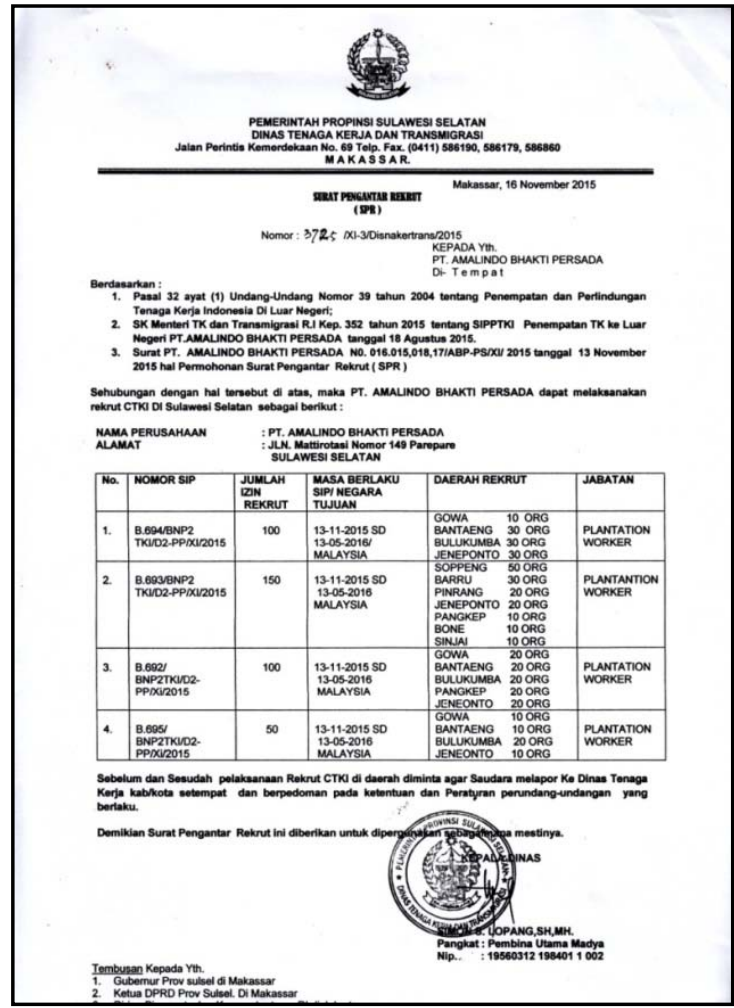

sumber: Dokumen PT. Amalindo Bhakti Persada, Pare-Pare

Informasi yang diperoleh dari SPR di atas yakni PT. Amalindo Bhakti Persada dapat melaksanakan rekrutmen CTKI di Sulawesi Selatan dengan jumlah izin rekrut yang diberikan sebanyak 400 orang dengan negara tujuan Malaysia dan daerah rekrut meliputi: Gowa, Bantaeng, 
Bulukumba Jeneponto, Soppeng, Barru, Pinrang, Pangkep, Sinjai dan Bone dengan jumlah yang telah ditentukan untuk masing-masing daerah.

Interaksi pemerintah dan PPTKIS (swasta) yang krusial pada masa pra-penempatan yakni proses rekrutmen TKI. Pekerja Migran Indonesia/Tenaga Kerja Indonesia (PMI/TKI) adalah setiap warga negara Indonesia yang memenuhi syarat untuk bekerja di luar negeri dalam hubungan kerja untuk jangka waktu tertentu dengan menerima upah. Sementara itu, Calon Tenaga Kerja Indonesia (CTKI) didefinisikan setiap warga negara Indonesia yang memenuhi syarat sebagai pencari kerja yang akan bekerja di luar negeri dan terdaftar di instansi pemerintah kabupaten/kota yang bertanggung jawab di bidang ketenagakerjaan. (Pasal 1 UU No. 39 Tahun 2004)

Pasal 35 UU No. 39/2004 menjelaskan syarat-syarat TKI untuk bekerja di luar negeri, antara lain: (1) berusia sekurang-kurangnya 18 tahun, kecuali bagi calon TKI yang dipekerjakan pada pengguna perseorangan/rumah tangga sekurang-kurangnya berusia 21 tahun; (2) sehat jasmani dan rohani; (3) tidak dalam keadaan hamil bagi calon tenaga kerja perempuan; (4) berpendidikan sekurang-kurangnya lulus SLTP atau yang sederajat; (5) terdaftar di Dinas Ketenagakerjaan di daerah tempat tinggalnya; (6) memiliki dokumen lengkap.

Poin 6 Pasal 35 UU No. 39/2004 tentang syarat bekerja di luar negeri dijelaskan lebih lanjut pada pasal 51 UU No. 39/2004 antara lain: (1) KTP, ijazah pendidikan terakhir, akte kelahiran atau surat keterangan kenal lahir; (2) surat keterangan status perkawinan, bagi yang telah 
menikah melampirkan copy buku nikah; (3) surat keterangan izin suami/istri, izin orang tua atau izin wali; (4) sertifikasi kompetensi kerja; (5) surat keterangan sehat berdasarkan hasil pemeriksaan kesehatan dan psikologi; (6) paspor yang diterbitkan oleh Kantor Imigrasi setempat; (7) visa kerja; (8) perjanjian penempatan TKI; (9) perjanjian kerja; dan (10) KTKLN (Kartu Tenaga Kerja Luar Negeri).

Penjelasan di atas secara jelas mendefinisikan bahwa pekerja migran Indonesia atau tenaga kerja Indonesia adalah warga negara Indonesia dengan kriteria: 1) memenuhi syarat untuk bekerja di luar negeri, 2) hubungan kerja untuk jangka waktu tertentu dan 3) menerima upah. Hal ini berlaku untuk PMI/TKI yang berasal dari berbagai wilayah di Indonesia, termasuk PMI asal Sulawesi Selatan. Seperangkat standar bagi pekerja migran Indonesia juga telah ditetapkan oleh pemerintah, sehingga penyimpangan/pelanggaran atas standar tersebut dapat mengakibatkan pekerja migran Indonesia tidak dapat dipenuhi hakhaknya.

Proses ini harus dikawal oleh PPTKIS dengan baik, karena menyangkut pemenuhan hak administratif TKI dan juga hak sosial ekonomi. Pemenuhan hak-hak pekerja migran Indonesia, termasuk pekerja migran asal Sulsel tersebut menurut PP No. 3 Tahun 2013 tentang Perlindungan Tenaga Kerja Indonesia di Luar Negeri meliputi: pemenuhan dokumen penempatan, penetapan biaya penempatan dan penetapan kondisi dan syarat kerja. 
Pemenuhan dokumen penempatan yang dimaksud antara lain: Kartu Tanda Penduduk (KTP), ijazah pendidikan terakhir, akte kelahiran, atau surat keterangan kenal lahir; sertifikat kompetensi kerja; surat keterangan sehat berdasarkan hasil pemeriksaan psikologi dan pemeriksaan kesehatan; paspor yang diterbitkan oleh Kantor Imigrasi setempat; visa kerja; Kartu Tenaga Kerja Luar Negeri (KTKLN); dan dokumen lain yang dipersyaratkan sesuai dengan ketentuan peraturan perundang-undangan.

Pemenuhan dokumen penempatan menjadi bagian dari tanggungjawab PPTKIS untuk memastikan bahwa TKI telah siap dengan dokumen tersebut. Andi Nagauleng, Direktur PT. Amalindo Bhakti Persada menjelaskan:

"Kami (PPTKIS) mempersiapkan berkas awal seperti KTP, KK, Akte Lahir dan Izin Ortu untuk digunakan mendaftar ID TKI. Melalui sistem ini juga berkas yang diminta keterangan sehat dari sarkes (sarana kesehatan) yang ditunjuk juga akan menginput hasil pemeriksaannya. ID ini digunakan selama proses penempatan, setelah semua lengkap dan sudah di PAP, maka lewat sistem ini juga e-KTKLN di cetak"14

Penjelasan di atas menunjukkan bahwa interaksi antara PPTKIS (swasta) dan pemerintah terus berjalan melalui sistem, sehingga tetap dalam pengawasan negara. Namun demikian, ada juga mekanisme yang berkaitan dengan rekrutmen tetapi dilakukan oleh mitra PPTKIS/agensi di Malaysia. Mustaslifah binti Mostyn, Bagian Pengurusan Agensi Pekerjaan Mospia menjelaskan Mekanisme kerjasama antara agensinya dengan PT. Amalindo, sebagai berikut:

${ }^{14}$ Ibid. 
"Pekerja dari Indonesia tidak semata-mata ingin bekerja dan disetujui oleh agensi. Merekapun mesti melewati tapisan. Tapisan pertama dari majikan, kami kirimkan nama-nama dari PT di Indonesia untuk diperiksa, ada record atau tidak. Apa pernah bekerja di perusahaan yang sama atau ada bad record. Setelah ada yang disetujui, kami antar daftar ke Imigresen. Imigresen punya tapisan tersendiri. Selepas tu baru dapat ambil lesen di JTK untuk dapat landing di Sabah dan kami inform ke PT"15

Pernyataan di atas memperlihatkan bahwa ada proses yang harus ditempuh di Malaysia. Proses ini berpotensi untuk memperpanjang waktu tunggu TKI, karena izin yang di urus oleh agensi menjadi penentu dikeluarkannya visa kerja oleh pemerintah Malaysia. Apabila CTKI pernah bekerja di Malaysia dan dipulangkan atau memiliki rekam jejak yang kurang baik di Malaysia, maka izin tentunya tidak dapat diberikan.

Pemenuhan hak ekonomi dalam proses rekrutmen menjadi elemen vital bagi pekerja migran asal Sulawesi Selatan sebagai bagian dari perlindungan TKI untuk mengetahui penetapan biaya penempatan berdasarkan negara tujuan dan sektor jabatan.Publikasi BSR dalam Step Up: Improving Recruitment of Migrant Workers in Indonesia menyatakan bahwa standar biaya rekrutmen tidak ada di Indonesia. Saat ini, biaya yang dikeluarkan meliputi: biaya kesehatan, biaya proses paspor, asuransi, biaya perjalanan dan pengeluaran administratif lainnya. Tidak adanya standar mengakibatkan terjadinya perbedaan pembayaran yang dilakukan oleh CTKI yang berpotensi meningkatkan biaya yang

\footnotetext{
${ }^{15}$ Wawancara dengan Mustaslifah binti Mostyn, Bagian Pengurusan Agensi Pekerjaan Mospia, 25 Mei 2016 di Tawau, Malaysia.
} 
dikeluarkan untuk bekerja di luar negeri. ${ }^{16}$ Berdasarkan hasil kajian dari BSR berikut skenario pembiayaan pada masa pra-penempatan:

Bagan 5.1 Skenario Biaya Rekrutmen

\begin{tabular}{|c|c|}
\hline \multicolumn{2}{|l|}{$\begin{array}{l}\text { More common } \\
\text { practice }\end{array}$} \\
\hline $\begin{array}{c}\text { Scenario } 1-\text { Worker Pays } \\
100 \% \text { of Fee }\end{array}$ & $\begin{array}{c}\text { Scenario } 2-\text { Worker Pays a } \\
\text { Portion of Fee }\end{array}$ \\
\hline $\begin{array}{l}\text { - A monthly amount is deducted } \\
\text { from the worker's paycheck } \\
\text { until the total recruitment fee } \\
\text { has been repaid. }\end{array}$ & $\begin{array}{l}\text { - A monthly amount is deducted } \\
\text { from the worker's paycheck for } \\
\text { a proportion and/or specific } \\
\text { fee element (for example, the } \\
\text { medical exam or } \\
\text { insurance).The cost is shared } \\
\text { with the employer. }\end{array}$ \\
\hline \multicolumn{2}{|c|}{$\begin{array}{l}\text { Variables include: } \\
\text { - Amount of interest charged-as little as } 7 \text { percent and as much as } 50 \\
\text { percent } \\
\text { - Repayment period-typically } 6 \text { months butcan be longer depending } \\
\text { on salary and fee amount }\end{array}$} \\
\hline
\end{tabular}

Less common practice

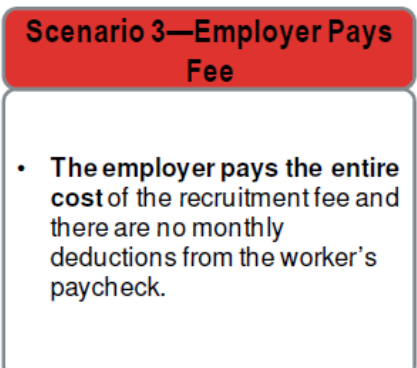

While not standard practice

among employers, Western

Digital and Sime Darby were

referenced as examples of

employers who pay all fees.

sumber: Bussiness for Social Responsibility

Bagan di atas menunjukkan bahwa skenario pertama yakni

TKI/PMI membayar $100 \%$ biaya, dimana setiap bulan mereka dikenai potongan hingga seluruh biaya penempatan dapat dibayarkan kembali. Skenario kedua yakni TKI/PMI membayar sejumlah tertentu, skemanya hampir sama dengan skenario pertama, perbedaannya terletak pada jumlah yang dibayarkan menyangkut elemen tertentu seperti: pemeriksaan kesehatan atau asuransi). Hal ini dikarenakan biaya juga dibebankan kepada perusahaan (PPTKIS maupun pengguna). Skenario ketiga yang jarang ditemui yakni perusahaan membayarkan seluruh biaya rekrutmen dan tidak ada potongan terhadap TKI/PMI.

\footnotetext{
${ }^{16}$ Business for Social Responsibility, 2011, Improving Migrant Worker Recruitment in Indonesia -

http://www.bsr.org/reports/Improving_Migrant_Worker_Recruitment_in_Indonesia.pdf, diakses 15 Juli 2016
} 
BSR menemukan bahwa praktek yang umum dilakukan yakni TKI/PMI dibebankan 100 persen biaya rekrutmen. TKI/PMI dengan pendapatan rata-rata 3 juta rupiah per bulan rata-rata mendapatkan potongan sebesar 500 ribu rupiah yang membawa dampak yang signifikan terhadap uang yang tersedia untuk digunakan sehari-hari dan dikirimkan ke kampung halaman. Salah satu TKI/PMI menyatakan bahwa enam bulan pertama saat bekerja di Malaysia, ia hanya memiliki sedikit uang yang tersisa untuk dikirimkan ke Indonesia. ${ }^{17}$

Pasal 39 UU No.39/2004 menyatakan bahwa segala biaya yang diperlukan dalam kegiatan perekrutan caton TKI, dibebankan dan menjadi tanggung jawab pelaksana penempatan TKI swasta. Lebih spesifik dalam Permenaker No. 22 Tahun 2014 dalam Pasal 42 ayat 1 dinyatakan bahwa PPTKIS hanya dapat membebankan biaya penempatan kepada calon TKI untuk komponen biaya: (a) pengurusan dokumen jati diri; (b) pemeriksaan kesehatan dan psikologi; (c) pelatihan kerja dan sertifikasi kompetensi kerja; (d) visa kerja; (e) akomodasi dan konsumsi selama masa penampungan; (f) tiket pemberangkatan dan retribusi jasa pelayanan bandara (airport tax); (g) transportasi lokal sesuai jarak asal TKI ke tempat pelatihan/penampungan; (h) premi asuransi.

PT. Amalindo Bhakti Persada, PPTKIS yang menyalurkan TKI/PMI asal Sulsel menyatakan bahwa PPTKIS memfasilitasi pengurusan dokumen untuk kelengkapan berkas pada masa pra-penempatan. Hal ini

${ }^{17}$ Ibid. 
untuk memastikan bahwa hak administratif TKI/PMI terpenuhi. ${ }^{18}$ Sedangkan pembiayaan yang dilakukan oleh pihak majikan (pengguna) dalam hal ini Felda Global Ventures Plantations (Malaysia) Sdn. Bhd. menanggung pembiayaan antara lain:

Tabel 5.3 Bayaran Kos Kemasukan Tahun Pertama Ditanggung Majikan

\begin{tabular}{|c|c|c|c|}
\hline No. & Komponen & $\begin{array}{l}\text { Biaya } \\
\text { (RM) }\end{array}$ & $\begin{array}{c}\text { Biaya (Rp.) } \\
{[1 \text { RM = }} \\
\text { Rp. 3.300] }\end{array}$ \\
\hline 1. & Levi & 590.00 & 1.947 .000 \\
\hline 2. & PLKS & 60.00 & 198.000 \\
\hline 3. & Proses (Administrasi) & 120.00 & 396.000 \\
\hline 4. & Single \& Multiple Entry Visa & 30.00 & 99.000 \\
\hline 5. & Insurance Guarantee & 57.70 & 190.410 \\
\hline 6. & Insuran Pekerja (SPPA) & 86.02 & 283.866 \\
\hline 7. & Medical Check-up (Growarisan) + 6\% gst & 201.40 & 664.620 \\
\hline 8. & $\begin{array}{l}\text { Penginapan/Makan/Minum sewaktu } \\
\text { pemeriksaan kesihatan di Tawau }\end{array}$ & 95.00 & 313.500 \\
\hline \multicolumn{2}{|r|}{ Jumlah } & 1.240 .12 & 4.092.396 \\
\hline
\end{tabular}

Sumber: Demand Letter PT. Amalindo Bhakti Persada dan Felda Global Ventures Plantations (Malaysia) Sdn. Bhd.

Tabel di atas menunjukkan bahwa biaya yang ditanggung oleh majikan (perusahaan pengguna jasa) di Malaysia cukup besar. Sehingga, perusahaan di Indonesia (Sulawesi Selatan) yang merekrut TKI/PMI harus memastikan bahwa TKI/PMI yang direkrut sesuai prosedur dari daerah asalnya.

Pemenuhan hak TKI lainnya yakni penetapan kondisi dan syarat kerja meliputi jam kerja, upah dan tata cara pembayaran, hak cuti dan waktu istirahat, fasilitas dan jaminan sosial. Andi Nagauleng, Direktur PT. Amalindo Bhakti Persada menjelaskan mengenai kondisi dan syarat kerja:

\footnotetext{
${ }^{18}$ Wawancara dengan Andi Nagauleng, S.E., Direktur Utama PT. Amalindo Bhakti Persada, 24 Maret 2016 di Pare-Pare.
} 
"Kondisi dan syarat kerja TKI di ladang telah diatur dalam perjanjian kontrak pekerjaan di antara PT. Felda Global Ventures Plantations zon Sabah dengan Tenaga Kerja Asing Ladang (TKI)"19

Penjelasan di atas hanya menyebutkan dasar perjanjian yang berisi kondisi dan syarat kerja. Informan memberikan copy dokumen tersebut kepada peneliti untuk menjadi referensi. Pertama, jam kerja dalam dokumen tersebut disebutkan bahwa waktu bekerja yang ditetapkan oleh majikan yaitu 8 jam sehari dan 6 hari seminggu dengan waktu mula kerja ditetapkan oleh pengurus ladang atau pegawai ladang.

Selanjutnya, upah dan tata cara pembayaran. Gaji/upah dan lainlain pembayaran insentif/bonus yang dibayar kepada pekerja adalah berdasarkan kepada jenis kerja, kuantiti kerja dan kualiti kerja yang dibuat. Kadar gaji/upah pekerja merujuk kepada arahan kerajaan perintah penetapan gaji minimum RM 900 sebulan berkuatkuasa pada 1 Januari 2013. Ada 2 jenis kadar upah yang ditawarkan oleh Majikan ialah Harian dan Kadaran (piece rates). Kaedah pembayaran merujuk Kadar Upah Kerja Ladang (KUK Ladang Sabah) supaya pembyaran upah dapat diseragamkan di semua ladang milik Felda di Sabah.

Hak cuti dan waktu istirahat dibagi ke dalam 4 kategori yakni:

(1) Cuti tahun - jumlah cuti yang diperuntukkan kepada setiap Pekerja setiap tahun. Kelayakan cuti bergantung kepada tahun perkhidmatan Pekerja berdasarkan Ordinan Sabah. Pekerja boleh memohon untuk bercuti tahun mengikut kelayakan kepada Pengurus ladang, namun kelulusan cuti akan diambil kira keperluan tenaga kerja semasa.

\footnotetext{
19 Ibid.
} 
(2) Cuti umum - cuti yang diumumkan oleh Kerajaan Malaysia dan Kerajaan Negeri Sabah dalam kalendar tahunan. Cuti umum yang telah diwartakan oleh Kerajaan Negeri Sabah ialah sebanyak 15 hari.

(3) Cuti sakit - cuti yang diberikan oleh pegawai perubatan/doctor yang diiktiraf karena Pekerja disahkan tidak sihat/sakit atau tidak mampu untuk menjalankan kerja setelah diperiksa. Cuti diberikan dalam 2 kategori yaitu sama ada berehat di rumah sakit (pesakit luar) atau dimasukkan ke wad/hospital.

(4) Cuti ke negara asal - kelayakan untuk bercuti ke negara asal adalah pekerja haruslah berkhidmat lebih dari 2 tahun dan cuti yang diperuntukkan ialah sebanyak 30-90 hari (cuti ini tidak berbayar), kelulusan cuti bergantung kepada pihak pengurusan ladang.

Berdasarkan penjelasan di atas maka dapat dipahami bahwa pekerja migran asal Sulawesi Selatan yang bekerja di perkebunan (PT. Felda) mendapatkan 4 kategori hak cuti. Cuti yang berlaku secara umum di Sabah yakni kategori 2, sedangkan kategori 1, 3 dan 4 atas kebijakan masing-masing majikan/pengguna.

Fasilitas dan jaminan sosial yang diperoleh oleh TKI yakni majikan akan menginsurankan semua pekerja asing yang bekerja dengan skim Pampasan Pekerja Asing (SPPA). Skim perlindungan insuran ini melindungi Pekerja di dalam waktu kerja dan di luar waktu kerja (24 jam) sepanjang tempo perkhidmatan yang dipersetujui. Skim ini dicarumkan 
oleh majikan dengan nilai maksima perlindungan ialah sebanyak RM 25.000 per orang.

Setelah TKI direkrut oleh PPTKIS dari daerah asal masing-masing serta telah bersesuaian dengan ketentuan di negara penempatan yakni Malaysia. TKI dari berbagai kabupaten/kota di Sulsel dipusatkan keberangkatannya di Pare-Pare. Koordinator P4TKI Pare-Pare, Zulkifli memberikan alasannya:

"Pare-Pare selama ini dipercaya sebagai tempat transit dari berbagai Kabupaten/Kota di Sulsel. Saat ini sarana kesehatan yang mempunyai izin sebagai sarkes TKI dan terkoneksi dengan SISKOTKLN di Sulsel hanya ada di RSUD Andi Makkasau, ParePare. Sarkes ini menjadi salah satu persyaratan memperoleh KTKLN. Setelah itu, perusahaan (PPTKIS) mengajukan permohonan PAP dan KTKLN kepada BP3TKI" ${ }^{20}$

Pernyataan di atas menunjukkan bahwa Kota Pare-Pare menjadi daerah yang perlu mendapatkan perhatian lebih dikarenakan saat ini perannya semakin sentral sebagai pintu keluar bagi TKI yang berangkat dari Sulawesi Selatan. Selain itu, kelembagaan P4TKI Pare-Pare yang merupakan pos pelayanan bagi TKI perlu dikuatkan agar mampu merespon dinamika dalam penempatan TKI.

Pos Pelayanan Penempatan dan Perlindungan TKI (P4TKI) ParePare memiliki tugas yakni melakukan pelayanan untuk memperlancar pemberangkatan dan pemulangan TKI di pintu-pintu embarkasi dan debarkasi. Sedangkan fungsi pos ini, antara lain: (1) pendataan dan informasi pemberangkatan dan pemulangan TKI; (2) pengkoordinasian penyediaan fasilitas pelayanan pemberangkatan dan pemulangan $\mathrm{TKI}$; (3)

\footnotetext{
${ }^{20}$ Wawancara dengan Mustaslifah binti Mostyn, Bagian Pengurusan Agensi Pekerjaan Mospia, 25 Mei 2016 di Tawau, Malaysia.
} 
penanganan awal bagi TKI yang mengalami gangguan fisik dan psikis dan (4) pengarahan penyelesaian masalah pemberangkatan dan pemulangan TKI.

Pembekalan Akhir Pemberangkatan (PAP) merupakan instrumen pemerintah untuk memberikan pembekalan kepada TKI. Pasal 69 ayat 1 UU No. 39/2004 menyatakan bahwa pelaksana penempatan TKI swasta wajib mengikutsertakan TKI yang akan diberangkatkan ke luar negeri dalam pembekalan akhir pemberangkatan. Andi Tenri Ulleng, Kepala Seksi Penempatan BP3TKI Makassar menyebutkan:

"Materi PAP yang diberikan antara lain: Adat Istiadat, Peraturan di Negara Tujuan, Perjanjian Kerja, Bahaya Narkoba dan Trafficking dan Mental Kepribadian"11

Materi yang disampaikan dalam PAP di atas diharapkan dapat menjadi bekal bagi TKI untuk dapat memahami kondisi negara penempatan dengan lebih baik dan dapat menghindarkan diri dari hal-hal yang dapat mencederai hak-hak TKI. Setelah mengikuti rangkaian tahapan sebelum diberangkatkan, PPTKIS melengkapi TKI dengan eKTKLN yang diterbitkan oleh BNP2TKI/BP3TKI/P4TKI sebagai identitas TKI/PMI legal dan prosedural. (E-KTKLN selengkapnya pada Lampiran 3)

BP3TKI Makassar sebagai lembaga vertikal dari BNP2TKI merupakan lembaga yang bertanggungjawab melakukan koordinasi penempatan TKI asal Sulsel. Tugas pokok lembaga ini yakni memberikan kemudahan pelayanan pemrosesan, seluruh dokumen penempatan, perlindungan dan penyelesaian masalah Tenaga Kerja Indonesia secara

\footnotetext{
${ }^{21}$ Wawancara dengan Tenri Ulleng, S.S., M.Pd., Kepala Seksi Penyiapan Penempatan BP3TKI Makassar, 30 Desember 2015 di Kantor BP3TKI Makassar
} 
terkoordinasi dan terintegrasi di seluruh wilayah masing-masing unit pelaksana teknis penempatan dan perlindungan tenaga kerja Indonesia dan dilakukan bersama-sama dengan instansi pemerintah terkait baik pemerintah pusat maupun pemerintah daerah. Salah satu luaran dari lembaga ini yakni data penempatan pekerja migran asal Sulawesi Selatan yang berasal dari 24 Kabupaten/Kota, sebagai berikut:

Tabel 5.4 Data Penempatan TKI ke Luar Negeri Kab/Kota Se Sulawesi Selatan Tahun 2012-2015

\begin{tabular}{|c|c|c|c|c|c|}
\hline \multirow[b]{2}{*}{ No. } & \multirow[b]{2}{*}{ Kabupaten I Kota } & \multicolumn{4}{|c|}{ Tahun } \\
\hline & & 2012 & 2013 & 2014 & $\begin{array}{c}2015 \\
\text { (sd Nov) }\end{array}$ \\
\hline 1. & Kab. Bantaeng & 1.568 & 1.415 & 725 & 293 \\
\hline 2. & Kab. Barru & 77 & 55 & 21 & 4 \\
\hline 3. & Kab. Bone & 158 & 200 & 89 & 32 \\
\hline 4. & Kab. Bulukumba & 1.047 & 869 & 672 & 107 \\
\hline 5. & Kab. Enrekang & 2 & 10 & 20 & 4 \\
\hline 6. & Kab. Gowa & 1.665 & 1.563 & 981 & 263 \\
\hline 7. & Kab. Jeneponto & 577 & 689 & 433 & 147 \\
\hline 8. & Kab. Kep. Selayar & 1 & 7 & 7 & 2 \\
\hline 9. & Kab. Luwu & 21 & 64 & 58 & 7 \\
\hline 10. & Kab. Luwu Timur & 6 & 15 & 14 & 7 \\
\hline 11. & Kab. Luwu Utara & 16 & 48 & 52 & 5 \\
\hline 12. & Kab. Maros & 42 & 71 & 54 & 14 \\
\hline 13. & Kab. Pangkep & 13 & 28 & 26 & 6 \\
\hline 14. & Kab. Pinrang & 126 & 148 & 144 & 75 \\
\hline 15. & Kab. Sidrap & 22 & 27 & 24 & 11 \\
\hline 16. & Kab. Sinjai & 15 & 21 & 15 & 1 \\
\hline 17. & Kab. Soppeng & 335 & 293 & 81 & 56 \\
\hline 18. & Kab. Takalar & 30 & 45 & 41 & 10 \\
\hline 19. & Kab. Tana Toraja & 18 & 23 & 25 & 3 \\
\hline 20. & Kab. Toraja Utara & - & 6 & 18 & 14 \\
\hline 21. & Kab. Wajo & 13 & 18 & 9 & 2 \\
\hline 22. & Kota Makassar & 236 & 664 & 509 & 112 \\
\hline 23. & Kota Palopo & 14 & 56 & 36 & 4 \\
\hline 24. & Kota Pare-Pare & 46 & 25 & 22 & 7 \\
\hline & Total & 6.048 & 6.360 & 4.076 & 1.186 \\
\hline
\end{tabular}

Sumber: BP3TKI Makassar 
Data di atas merepresentasikan pekerja migran asal Sulawesi Selatan yang ditempatkan melalui prosedur ke Malaysia berdasarkan hasil rekapitulasi BP3TKI Makassar. Sedangkan pekerja migran asal Sulsel tersebut ditempatkan ke negara-negara berikut:

Tabel 5.5 Negara Penempatan TKI Tahun 2012-2015 Se Wilayah BP3TKI Makassar (Makassar, Pare-Pare, Mamuju)

\begin{tabular}{|c|c|c|c|c|c|}
\hline \multirow[b]{2}{*}{ No. } & \multirow[b]{2}{*}{ Negara } & \multicolumn{4}{|c|}{ Tahun } \\
\hline & & 2012 & 2013 & 2014 & $\begin{array}{c}2015 \\
\text { (sd Nov) }\end{array}$ \\
\hline 1. & Malaysia & 5.959 & 6.028 & 3.514 & 1098 \\
\hline 2. & Arab Saudi & 110 & 171 & 231 & 51 \\
\hline 3. & Brunei Darussalam & 55 & 22 & 29 & 4 \\
\hline 4. & Jepang & 52 & 69 & 47 & 30 \\
\hline 5. & Singapura & 52 & 230 & 166 & 14 \\
\hline 6. & Hongkong & 21 & 35 & 14 & - \\
\hline 7. & Korea Selatan & 17 & 7 & 9 & 1 \\
\hline 8. & Kuwait & 16 & 17 & 7 & 1 \\
\hline 9. & Uni Emirat Arab & 6 & 66 & 127 & 4 \\
\hline 10. & Amerika Serikat & 4 & 27 & 12 & 1 \\
\hline 11. & Kamboja & - & - & - & - \\
\hline 12. & Laos & 2 & 14 & 6 & - \\
\hline 13. & Myanmar & - & 4 & 1 & - \\
\hline 14. & Filipina & - & - & - & - \\
\hline 15. & Thailand & 1 & 24 & 21 & 2 \\
\hline 16. & Vietnam & 2 & 2 & 6 & - \\
\hline 17. & Lainnya & 27 & 234 & 229 & 81 \\
\hline & Total & 6.324 & 6.950 & 4.419 & 1.287 \\
\hline
\end{tabular}

Sumber: BP3TKI Makassar

Data di atas menunjukkan Malaysia merupakan negara tujuan dengan jumlah penempatan terbesar selama 4 tahun (2012-2015). Hal ini menunjukkan bahwa Malaysia merupakan negara tujuan favorit pekerja migran asal Sulawesi Selatan. Malaysia mendominasi penempatan TKI ke luar negeri pada tahun 2012 (94,2 persen), 2013 (86,7 persen), 2014 (79.5 persen) dan 2015 (85,3 persen). Jika dibandingkan dengan negara 
anggota ASEAN yang lain (kecuali Malaysia), TKI asal Sulsel juga ditempatkan ke Brunei Darussalam, Singapura dan Thailand.

Apabila ditinjau secara normatif pemerintah di pusat hingga daerah memberikan pelayanan terhadap TKI (melalui PPTKIS) dengan tahapan yang berjenjang mulai dari pengesahan job order/demand letter dari majikan/pengguna di negara penempatan oleh perwakilan RI, penerbitan Surat Izin Pengerahan (SIP) oleh BNP2TKI/BP3TKI hingga penerbitan Surat Pengantar Rekrut (SPR) oleh Dinas Tenaga Kerja Provinsi. Keseluruhan proses tersebut merupakan upaya pemerintah untuk menjalankan kebijakan penempatan dan perlindungan TKI.

Namun demikian, interaksi yang terjadi antara pemerintah dan swasta terkadang tidak berjalan sebagaimana diharapkan. Bahkan TKI yang merupakan objek pemerintah untuk ditempatkan dan dilindungi dalam beberapa kasus tidak mau mengikuti aturan (prosedur) yang telah ditetapkan oleh pemerintah. Akibatnya masa pra-penempatan yang memegang peran vital dalam mempersiapkan calon TKI justru menjadi pangkal permasalahan TKI di negara penempatan.

Berikut ini beberapa kasus pekerja migran asal Sulawesi Selatan dengan pengalaman yang berbeda-beda menanggapi prosedur yang ditetapkan oleh pemerintah yang harus dipenuhi oleh swasta untuk menempatkan TKI/PMI.

Muh. Fadhli (21 tahun) CTKI Prosedural asal Pangkep, Sulsel dari PT. ABP menceritakan:

"Saya pertama kali ini berangkat ke Malaysia. Keluarga sudah ada yang duluan di sana dan diajak kerja, tapi lewat proses di 
perusahaan dulu. Rencana mau kerja di perkebunan kelapa sawit. Saya melengkapi dokumen dibantu oleh perusahaan (PT. ABP), setelah sampai di Pare-Pare dilakukan cek kesehatan di RS dan didaftarkan untuk asuransi. Harapannya bekerja di Malaysia pulang bawa uang, walaupun saya sudah menunggu di proses selama 4 bulan, tetapi sabar saja"

Proses ini juga dirasakan oleh Fery Irawan (20 tahun) CTKI prosedural asal Pangkep yang juga pertama kali berangkat dan diproses selama 4 bulan. la merasa proses yang cukup lama tersebut biasa saja. Harapannya sama yakni dapat membawa pulang uang dari hasil kerjanya nanti. Sedangkan Dimas (27 tahun) CTKI prosedural asal Barru bahkan berproses lebih lama yakni 7 bulan. la bahkan mengajak anggota keluarganya untuk turut bekerja di Malaysia dengan harapan bahwa ia dapat bekerja di Malaysia dan pulang membawa uang. Ketiga potret CTKI prosedural ini bukan tidak memiliki pekerjaan sebelumnya, Muh. Fadhli meninggalkan pekerjaannya di industri ban. Fery sebelumnya bekerja di salah satu pabrik Semen sedangkan Dimas adalah Petani.

Berbeda dengan yang dialami oleh Johan (33 tahun) asal Toraja, ia menceritakan proses penempatannya yang berada pada masa transisi.

"Saya pernah menjadi TKI yang hanya berbekal paspor ketika berangkat pertama kali ke Malaysia tahun 2000.Saya berangkat bersama teman-teman satu kampung ke Sabah untuk bekerja di ladang sawit. Kami sempat ditangkap waktu itu karena beberapa di antara kami ada yang tidak memiliki paspor. Tetapi akhirnya setelah di lepas kami dipulangkan kembali ke kampung. Setelah itu saya mencoba lagi berangkat tetapi tidak lagi satu kampung yang jumlahnya 33 orang, saya membentuk kelompok kecil yang hanya berjumlah 5 orang, dan seluruhnya sudah memiliki paspor. Kami lolos dan bisa menyeberang ke Malaysia. Sampai di Malaysia saya kerja di ladang sawit selama 4 tahun di ladang yang berbeda-beda. Hingga paspor saya habis dan kembali lagi ke Nunukan untuk memperpanjang di Imigrasi. Tetapi ketika ingin kembali lagi ke Malaysia saya ditahan. Akhirnya saya ke Pare-Pare untuk 
mengurus lewat perusahaan dan bisa kembali bekerja di Malaysia setelah melengkapi dokumen-dokumen".

Johan mengaku berangkat pertama kali pada tahun 2000. Kondisi waktu itu pemerintah belum mengatur secara ketat penempatan TKI. Di samping itu kebutuhan atas tenaga kerja dan masih longgarnya aturan di negara penempatan terkait ketenagakerjaan menjadikan proses prapenempatan masih memberi ruang bagi TKI yang berbekal paspor untuk bekerja di Malaysia. Tetapi pemerintah pada waktu itu telah mengantisipasi terjadinya perdagangan manusia (trafficking), sehingga pemberangkatan dalam jumlah besar seperti yang dilakukan Johan dan warga sekampungnya dihalangi oleh aparat penegak hukum. Memasuki tahun 2004 ketika UU yang mengatur tentang penempatan TKI disahkan dan aturan untuk melintas bagi tenaga kerja semakin ketat. Johan mengalami kesulitan untuk bekerja kembali di Malaysia dan akhirnya melalui jalur prosedural.

Pengalaman berbeda dialami Asma asal Pare-Pare yang menceritakan proses ia ditempatkan.

"Saya berangkat dari Pare-Pare ke Sabah tidak pake surat, dibawa teman satu kampung. Kejadiannya tahun 1995. Kami berangkat dari pelabuhan Pare-Pare rombongan kira-kira 50 orang. Kami dijanji untuk bekerja di ladang sawit. Saat itu tidak ada masalah saat perjalanan hingga kami tiba di Malaysia. Tetapi kami mengalami masalah saat tiba di ladang dan dikejar-kejar polis"

Ketiga kasus yang dialami CTKI maupun TKI Purna di atas menunjukkan karakteristik yang berbeda dan tingkat keterlibatan pemerintah dan swasta yang juga berbeda. Di rentang waktu 1995-2000 yang dialami Asma asal Pare-Pare dan Johan asal Toraja pengawasan yang diberikan pemerintah terhadap TKI masih minim, sehingga migrasi 
kerja yang terjadi masih bersifat alami. Memasuki masa penerapan UU No. 39 Tahun 2004 seperti yang dialami Johan saat kembali bekerja di Malaysia, perusahaan mulai masuk untuk menempatkan TKI, sehingga kriteria prosedural adalah yang mengikuti ketentuan UU yang telah ditetapkan oleh pemerintah. Pelaksanaan UU semakin diperkuat seiring berjalannya waktu, sehingga masa pra-penempatan yang dialami oleh Muh. Fadhli asal Pangkep, Fery Irawan asal Pangkep dan Dimas asal Barru membutuhkan waktu tunggu hingga 4-7 bulan sebelum diberangkatkan untuk melengkapi dokumen-dokumen yang dipersyaratkan.

Proses migrasi yang pada awalnya berlangsung secara alami berdasarkan kasus yang ditemukan di lapangan hingga masuknya pengaturan pemerintah melalui Undang-Undang. Mempengaruhi kelembagaan yang terlibat dalam proses migrasi kerja ini. Lembaga yang awalnya hanya melibatkan Imigrasi yang menerbitkan paspor bagi WNI yang hendak ke luar negeri dan visa kerja yang diurus oleh pemilik ladang yang mempekerjakan TKI, semakin berkembang dengan seperangkat lembaga pemerintah maupun perusahaan (swasta) yang diamanatkan terlibat dalam proses ini. Keterlibatan lembaga pemerintah dan swasta ini berkontribusi terhadap perubahan pola migrasi TKI asal Sulsel.

\subsection{Peran Masyarakat Sipil}

Lembaga Swadaya Masyarakat (LSM) merupakan pengembangan dari organisasi non-pemerintah (omop) atau juga disebut sebagai lembaga non-governmental organization (NGO). Sehingga dapat dipahami bahwa 
Lembaga swadaya masyarakat merupakan sebuah organisasi di luar pemerintah, di luar birokrasi, tujuannya bisa membantu kinerja pemerintah bahkan justru ikut mengawasi jalannya pemerintahan agar tidak menjadi penyebab terjadinya penyalahgunaan kewenangan. Secara umum pengertian lembaga swadaya masyarakat (LSM) merupakan semua organisasi yang tidak terikat dengan pemerintah dan birokrasi. ${ }^{22}$

Fungsi LSM di Indonesia sebagai berikut:

(1) Wadah organisasi yang menampung, memproses, mengelola dan melaksanakan semua aspirasi masyarakat dalam bidang pembangunan terutama pada bagian yang kerap kali tidak diperhatikan oleh pemerintah;

(2) Menumbuhkembangkan jiwa dan semangat, serta memberdayakan masyarakat dalam bidang pembangunan;

(3) Melaksanakan, mengawasi, memotivasi dan merancang proses dan hasil pembangunan secara berkesinambungan;

(4) Memelihara dan menciptakan suasana yang kondusif di dalam kehidupan masyarakat;

(5) Wadah penyalur aspirasi atas hak dan kewajiban warga negara dan kegiatan dari masyarakat sesuai dengan tujuan yang telah ditetapkan oleh masing-masing Lembaga swadaya masyarakat;

(6) Menggali dan mengembangkan segala potensi yang dimiliki oleh anggotanya sehingga dapat mewujudkan tujuan yang telah ditetapkan bersama;

\footnotetext{
${ }^{22}$ Guru PPKN, n.d., Fungsi Lembaga Swadaya Masyarakat - http://guruppkn.com/fungsilembaga-swadaya-masyarakat, diakses 18 Juli 2016.
} 
(7) Wadah yang berperan mensukseskan pembangunan bangsa dan negara, serta dalam hal ini ikut menjaga kedaulatan negara serta menjaga ketertiban sosial.

Lembaga Swadaya Masyarakat (LSM) yang aktif mengadvokasi hak-hak TKI, beberapa diantaranya: Migrant CARE, Serikat Buruh Migran Indonesia maupun Yayasan TIFA, ketiga LSM ini berkantor di Jakarta. Peneliti mengunjungi satu dari tiga LSM tersebut yakni Migrant CARE. Mike Verawati, Aktivis Migrant CARE mengungkapkan fakta tentang TKI asal Sulsel:

"Sulawesi Selatan gak terlalu banyak (masalahnya). Migrant CARE banyak menangani TKI asal NTB, NTT, Papua, Sorong, Jawa Barat dan Jawa Timur. TKI asal Sulsel relatif tidak punya masalah dengan tata kelola yang cukup baik, jika dibandingkan tata kelola migrasi di tempat lain. Walaupun kita tahu bersama bahwa bekerja di luar negeri negara manapun rentan permasalahan"23

Pernyataan di atas menunjukkan bahwa LSM yang berada di luar Sulawesi Selatan menaruh perhatian terhadap kondisi TKI asal Sulsel. Walaupun menurut informasi di atas TKI asal Sulsel relatif minim masalah pada masa pra-penempatan. Selain Migrant CARE dalam penelitian ini peneliti sempat menjajaki LSM yang peduli dengan permasalahan TKI asal Sulsel yang secara nasional mengurusi persoalan migrasi yakni International Organization of Migration (IOM) yang juga memiliki kantor di Makassar, namun kantor lembaga ini tidak ditemukan.

Peran masyarakat sipil pada masa pra-penempatan di Sulawesi Selatan belum terlihat. Namun demikian, aturan main yang ditetapkan oleh pemerintah terhadap swasta masih diikuti, sehingga ketiadaan peran

\footnotetext{
${ }^{23}$ Wawancara dengan Mike Verawati, Project Officer Advokasi Buruh Migran berbasis Teknologi, 18 Mei 2016 di Jakarta.
} 
masyarakat sipil tidak berdampak signifikan terhadap aktivitas di pasar ekonomi maupun politik.

Berdasarkan pemaparan pada tiga bagian di atas, maka secara sederhana pemenuhan hak-hak pekerja migran asal Sulawesi Selatan pada masa pra-penempatan dapat dilihat dari tabel berikut:

Tabel 5.6 Pemenuhan Hak-Hak Pekerja Migran asal Sulsel pada Masa Pra-Penempatan

\begin{tabular}{|c|c|c|}
\hline No. & Analisis Ekonomi Politik & Tinjauan \\
\hline 1 & Peran Pemerintah & $\begin{array}{l}\text { - Tugas pemerintah mengatur, } \\
\text { membina, melaksanakan dan } \\
\text { mengawasi penyelenggaraan } \\
\text { penempatan dan perlindungan TKI di } \\
\text { luar negeri } \\
\text { - Pemerintah berkewajiban menjamin } \\
\text { terpenuhinya hak-hak calon TKI/TKI } \\
\text { - Peran pemerintah dalam pengesahan } \\
\text { job order/demand letter oleh KRI Tawau } \\
\text { - Penerbitan Surat Izin Pengerahan } \\
\text { (SIP) oleh BNP2TKI } \\
\text { - Penerbitan Surat Pengantar Rekrut } \\
\text { (SPR) oleh Disnaker Prov. Sulsel } \\
\text { - Peran pemerintah daerah di kota } \\
\text { Makassar, kabupaten Gowa dan kota } \\
\text { Pare-Pare dalam memberikan } \\
\text { pelayanan terhadap TKI/PMI }\end{array}$ \\
\hline 2 & $\begin{array}{l}\text { Interaksi Pemerintah dan } \\
\text { Swasta }\end{array}$ & $\begin{array}{l}\text { - PPTKIS wajib memiliki Surat Izin } \\
\text { Pelaksana Penempatan Tenaga Kerja } \\
\text { Indonesia (SIPPTKI) dari pemerintah } \\
\text { dengan seperangkat persyaratan } \\
\text { "finansial" untuk merekrut TKI } \\
\text { - PPTKIS mendampingi } \\
\text { majikan/pengguna TKI di Malaysia } \\
\text { untuk mempersiapkan job } \\
\text { order/demand letter serta dokumen } \\
\text { pendukung lainnya. } \\
\text { - PPTKIS mengurus SIP ke BNP2TKI } \\
\text { via BP3TKI dengan sejumlah } \\
\text { persyaratan } \\
\text { - PPTKIS mengurus SPR ke } \\
\text { Disnakertrans Prov. Sulsel dengan } \\
\text { menyertakan SIP }\end{array}$ \\
\hline
\end{tabular}




\begin{tabular}{|c|c|c|}
\hline & & $\begin{array}{l}\text { - Disnakertrans Prov. Sulsel } \\
\text { mengalokasikan daerah rekrut yang } \\
\text { menjadi batasan bagi PPTKIS } \\
\text { - Pemenuhan hak administratif } \\
\text { (dokumen) dan hak ekonomi (gaji/upah } \\
\text { di Malaysia) atas TKI yang dijamin } \\
\text { pemerintah oleh PPTKIS } \\
\text { - Majikan/pengguna dan pemerintah } \\
\text { Malaysia menerapkan mekanisme } \\
\text { "tapisan" untuk menjamin TKI yang } \\
\text { ditempatkan bebas masalah dan dapat } \\
\text { dijamin hak-haknya } \\
\text { - PPTKIS wajib mengikutkan TKI untuk } \\
\text { diberikan Pembekalan Akhir } \\
\text { Pemberangkatan (PAP) oleh } \\
\text { pemerintah melalui BP3TKI/P4TKI } \\
\text { - PPTKIS membekali TKI dengan E- } \\
\text { KTKLN yang diterbitkan pemerintah } \\
\text { sebagai identitas TKI yang legal dan } \\
\text { prosedural } \\
\text { - Kasus yang dialami TKI pada masa } \\
\text { pra-penempatan memiliki karakteristik } \\
\text { berdasarkan tingkat keterlibatan } \\
\text { pemerintah dan swasta yang berbeda. }\end{array}$ \\
\hline 3 & Peran Masyarakat Sipil & $\begin{array}{l}\text { - LSM yang aktif terbatas } \\
\text { - LSM yang aktif berpusat di Jakarta } \\
\text { (Ibukota) } \\
\text { - Migrant CARE (LSM) menyatakan TKI } \\
\text { Sulsel tidak ada masalah } \\
\text { - Peran LSM di Sulsel belum terlihat }\end{array}$ \\
\hline
\end{tabular}

Sumber: Diolah oleh Peneliti

Berdasarkan pemaparan di atas bersesuaian dengan pendekatan peran hukum dalam ekonomi politik kelembagaan yang dikemukakan oleh Commons, Coase dan North. Pakar kelembagaan menyatakan bahwa ekonomi pasar tidak tercipta dengan sendirinya. Ekonomi pasar perlu memenuhi prasyarat tegaknya suatu institusi yang dapat mengatur pola interaksi beberapa aktor dalam suatu arena transaksi yang disepakati bersama. Kelembagaan dilihat dari sisi hukum menentukan dan/atau mewarnai transaksi, terutama melalui aturan main yang berlaku, sekaligus 
juga mengatur kelompok atau agen ekonomi untuk mewujudkan kontrol kolektif terhadap transaksi.

Pandangan yang dikemukakan oleh Commons, Coase dan North mendukung asumsi peneliti bahwa pemenuhan hak-hak pekerja migran asal Sulawesi Selatan perlu di analisis dari sisi ekonomi politik kelembagaan, khususnya dalam melihat peran hukum/kebijakan. Peran pemerintah, interaksi pemerintah dan swasta, serta peran masyarakat sipil di atas menunjukkan bahwa pemerintah menerapkan seperangkat aturan untuk dipenuhi oleh PPTKIS (swasta). Hal ini direspon dengan baik oleh PT. Amalindo Bhakti Persada, salah satu PPTKIS yang berkantor pusat di Sulawesi Selatan. Perusahaan ini secara administratif berupaya untuk memenuhi ketentuan pemerintah. Selain itu, pemerintah Malaysia yang merupakan negara penempatan turut mengawasi pekerja migran Indonesia yang akan masuk ke negaranya melalui sistem tapisan yang dilakukan oleh majikan maupun pihak Jabatan Imigresen. Hal ini membentuk sistem ekonomi politik kelembagaan yang kondusif sehingga sinergi pemerintah dan swasta dapat terjaga.

Tanggapan dari CTKI dan Purna TKI asal Sulsel terhadap interaksi pemerintah dan swasta berdasarkan kasus yang ditemui di lapangan menunjukkan terjadinya perubahan tingkat keterlibatan pemerintah dalam rentang waktu TKI menjalani proses migrasi kerja. Rentang waktu 19952000, migrasi yang terjadi masih bersifat alami dan keterlibatan pemerintah masih minim, pengawasan yang dilakukan masih terbatas pada pengendalian jumlah WNI yang berangkat seperti yang disampaikan 
informan. Saat UU No. 39 Tahun 2004 diterapkan, pemerintah mulai mengatur keterlibatan perusahaan (swasta) dalam proses migrasi dengan menerapkan syarat-syarat bagi pelaksana penempatan TKI swasta (PPTKIS) dan Tenaga Kerja Indonesia (TKI) yang akan diberangkatkan maupun majikan/pengguna yang akan mempekerjakan TKI. Hal ini berdampak terhadap waktu tunggu bagi TKI asal Sulsel yang akan diberangkatkan mencapai 4-7 bulan berdasarkan pengalaman informan. Sehingga muncul persoalan baru yakni TKI asal Sulsel yang menempuh jalur non-prosedural dikarenakan proses pra-penempatan yang lama, sedangkan mayoritas TKI berorientasi untuk segera bekerja dan mendapatkan gaji.

Model interaksi yang terbentuk dari analisis ekonomi politik dalam pemenuhan hak-hak pekerja migran asal Sulawesi Selatan pada masa pra-penempatan berdasarkan identifikasi Bustanul Arifin dalam Deliarnov yakni model invisible hand. Ditinjau dari sisi sistem hukum, pemerintah menyediakan sarana dan prasarana dasar seperti pelayanan penempatan TKI. Sistem hukum ditegakkan dan diterapkan kepada swasta untuk melaksanakan penempatan TKI ke Malaysia sesuai ketentuan. Sedangkan tinjauan peraturan/regulasi pemerintah mengeluarkan peraturan dan ikut mematuhi peraturan. Peran dunia usaha (swasta) dalam ekonomi cukup besar, sehingga dapat membuka kesempatan kerja ke luar negeri bagi masyarakat. 


\subsection{Pemenuhan Hak-Hak Pekerja Migran asal Sulawesi Selatan di Malaysia pada Masa Penempatan}

\subsubsection{Peran Pemerintah}

Tugas, tanggungjawab dan kewajiban pemerintah Indonesia dalam pemenuhan hak-hak pekerja migran melintasi batas negara melalui perwakilannya di negara penempatan. Penelitian ini dilakukan di Tawau, Sabah Malaysia yang merupakan daerah transit bagi TKI sebelum masuk ke ladang/perkebunan yang tersebar di wilayah Sabah Malaysia. Konsulat Republik Indonesia (KRI) Tawau merupakan perwakilan pemerintah Indonesia dengan wilayah kerja meliputi: Majelis Perbandaran Kota Tawau, Majelis Daerah Lahad Datu, Majelis Daerah Kunak dan Majelis Daerah Semporna.

Perwakilan pemerintah Indonesia di Tawau hadir pada tahun 1961, ketika Kantor Perwakilan tingkat Konsulat di Kota Kinabalu yang wilayah kerjanya meliputi Sabah dan Serawak. Pada tahun 1968, Kantor Perwakilan Republik Indonesia di Tawau dibuka dengan nomenklatur Kantor Perwakilan Imigrasi dan Bea Cukai. Pada September tahun 2004, penyebutannya berubah menjadi Kantor Pelaksana Tugas dan Fungsi (KPTF) KJRI Kota Kinabalu di Tawau. Pada tanggal 29 Desember 2010, pemerintah Indonesia memutuskan untuk menetapkan KPTF KJRI Kota Kinabalu di Tawau menjadi Kantor Konsulat Republik Indonesia (KRI) Tawau. $^{24}$

\footnotetext{
${ }^{24}$ Konsulat Republik Indonesia Tawau. 2014. Tugas Pokok dan Fungsi Konsulat Republik Indonesia Tawau. Tawau: KRI Tawau. h. 11.
} 
KRI Tawau merupakan wujud kehadiran pemerintah Indonesia pada masa penempatan. Krishna Djelani, Kepala Subdirektorat Pengawasan Kekonsuleran, Direktorat Perlindungan WNI dan BHI Kementerian Luar Negeri RI menyatakan:

"Undang-Undang Nomor 39 Tahun 2004 Tentang Penempatan dan Perlindungan TKI di Luar Negeri pada Pasal 6 telah secara tegas menyebutkan bahwa pemerintah bertanggung jawab untuk meningkatkan upaya perlindungan TKI di luar negeri. Lebih lanjut dalam Peraturan Menlu Nomor 04 Tahun 2008 Tentang Pelayanan Warga Pada Perwakilan RI di Luar Negeri pada Pasal 1 huruf (k) menekankan bahwa perlindungan warga adalah segala upaya yang dilakukan oleh Perwakilan untuk melayani dan melindungi warga. Menteri Luar Negeri, Ibu Retno Marsudi dalam arahannya menitikberatkan perlindungan WNI sebagai salah satu dari 4 (empat) prioritas politik luar negeri, selain melindungi kedaulatan bangsa, memajukan diplomasi ekonomi, dan peningkatan kerjasama regional dan internasional." ${ }^{25}$

Pernyataan di atas merupakan sikap Kementerian Luar Negeri RI terhadap perlindungan Warga Negara Indonesia di luar negeri, termasuk pekerja migran Indonesia. Informan menyebutkan rujukan dasar dari penelitian ini yakni UU No. 39 Tahun 2004 yang juga menjadi dasar bagi Kemlu untuk memberikan perlindungan bagi TKI. Ditekankan juga dalam Peraturan Menlu No. 04 Tahun 2008 mengenai pelayanan dan perlindungan WNI oleh perwakilan RI di luar negeri. Menteri Luar Negeri RI, Ibu Retno Marsudi semakin menegaskan bahwa perlindungan WNI sebagai salah satu pilar prioritas politik luar negeri Indonesia. Garis koordinasi yang vertikal antara Kemlu dengan perwakilan RI di seluruh dunia tentunya menjadikan sikap Kemlu ini sebagai acuan dalam memberikan pelayanan kepada WNI di luar negeri, termasuk TKI/PMI.

\footnotetext{
${ }^{25}$ Wawancara dengan Krishna Djelani, Kepala Subdirektorat Pengawasan Kekonsuleran, Direktorat Perlindungan WNI dan BHI Kementerian Luar Negeri RI, 13 Mei 2016 di Kompleks Kemlu RI, Jakarta.
} 
Dian Ratri Astuti, Kepala Kanselerai/Fungsi Pensosbud KRI Tawau menyatakan bahwa:

"Perwakilan RI seyogyanya mengikuti arahan dari Kementerian Luar Negeri, karena orang-orang yang ditempatkan di perwakilan RI merupakan staf Kemlu. Setiap perwakilan RI memiliki tantangan masing-masing di negara tugasnya, tetapi dasar kebijakannya tentu mengacu pada hukum nasional dan juga arahan menteri. KRI Tawau yang berada di perbatasan Malaysia-Indonesia dan jadi pintu masuk bagi TKI, tentu memiliki prioritas untuk memberikan pelayanan dan perlindungan bagi TKI." ${ }^{26}$

Pernyataan di atas menegaskan posisi perwakilan RI sebagai wakil pemerintah Indonesia di negara penempatan. Nilai-nilai dasar kebijakan Kemlu dan tantangan di wilayah kerja KRI Tawau membentuk visi perwakilan RI ini yakni: terwujudnya kepentingan nasional dan optimalisasi pelayanan dan perlindungan terhadap WNI di wilayah kerja. Visi di atas sejalan dengan kewajiban pemerintah untuk melakukan upaya diplomatik untuk menjamin pemenuhan hak dan perlindungan TKI secara optimal di negara tujuan dan memberikan perlindungan kepada TKI pada masa penempatan.

Selanjutnya misi KRI Tawau yakni: (1) meningkatkan pelayanan kekonsuleran dan perlindungan terhadap WNI/BHI di wilayah kerja, (2) meningkatkan kerjasama bilateral di berbagai bidang dan people-topeople relation dengan melibatkan seluruh lapisan dan elemen di wilayah kerja dan pemangku kepentingan terkait di Indonesia, (3) meningkatkan kerjasama bidang trade, tourism dan investment, (4) menjaga keutuhan wilayah kerja NKRI melalui kerjasama yang konstruktif diantara pemangku kepentingan terkait di wilayah perbatasan dan (5) mewujudkan sarana dan

\footnotetext{
${ }^{26}$ Wawancara dengan Dian Ratri Astuti, Kepala Kanselerai/Fungsi Pensosbud KRI Tawau, 24 Mei 2016 di Kantor KRI Tawau.
} 
prasarana aparatur negara, serta tata kelola pemerintahan yang baik (good governance) dalam bidang pelayanan publik/masyarakat di wilayah kerja. $^{27}$

Urusan ketenagakerjaan merupakan salah satu tugas pokok dan fungsi dari Konsulat RI Tawau. Urusan ini dijalankan dengan mengacu pada empat tugas dan fungsi yakni: (1) memberikan pelayanan ketenagakerjaan, (2) memberikan perlindungan terhadap TKI, (3) membangun hubungan yang sinergi antara majikan (perusahaan/pengguna jasa), TKI dan pihak terkait di wilayah kerja dan (4) meningkatkan kesejahteraan TKI. $^{28}$ Dian Ratri Astuti, Kepala Kanselerai/Fungsi Pensosbud KRI Tawau menjelaskan lebih lanjut:

"Tugas dan fungsi pelayanan ketenagakerjaan diwujudkan dalam perlindungan WNI/TKI yang terdiri atas: pelayanan pengesahan ahli waris, pelayanan pemulangan jenazah ke Indonesia, pelayanan pemberian kontrak kerja, pelayanan penerimaan TKI di shelter KRI Tawau, pelayanan penyelesaian perselisihan antara WNI/TKI dengan pihak lain dan pelayanan rekrutmen TKI (demand letter)." ${ }^{29}$

Pernyataan di atas sesuai dengan turunan UU No. 39 Tahun 2004 dalam PP No. 3 Tahun 2013 terkait perlindungan TKI pada masa penempatan yang meliputi: (a) pembinaan dan pengawasan; (b) bantuan dan perlindungan kekonsuleran; (c) pemberian bantuan hukum; (d) pembelaan atas pemenuhan hak-hak TKI; dan (e) perlindungan dan bantuan lainnya sesuai dengan ketentuan peraturan perundang-undangan serta hukum dan kebiasaan internasional; dan (f) upaya diplomatik. Peran pemerintah dalam pemberian perlindungan TKi dan pemenuhan hak-

\footnotetext{
${ }^{27}$ Konsulat Republik Indonesia Tawau, 2014, op.cit. h. 7.

28 Ibid. hh. 21-22.

${ }^{29}$ Wawancara dengan Dian Ratri Astuti, Kepala Kanselerai/Fungsi Pensosbud KRI Tawau, 24 Mei 2016 di Kantor KRI Tawau.
} 
haknya akan dibahas lebih lanjut pada bagian interaksi pemerintah dan swasta, karena banyak melibatkan majikan/pengguna sebagai pihak yang tidak menjalankan hak-haknya kepada TKI.

Deportasi merupakan upaya mewujudkan perlindungan TKI/WNI di wilayah kerja KRI Tawau. Dian Ratri Astuti, Kepala Kanselerai/Fungsi Pensosbud KRI Tawau mengemukakan data terkini:

"Mengacu pada laporan (LKj) KRI Tawau data deportasi WNI/BMI dalam setahun terakhir, tahun 2015 berjumlah 6.014 orang. Jumlah tersebut merupakan jumlah total bersama WNI/BMI dari wilayah kerja KJRI Kota Kinabalu dan KRI Tawau. Semua WNI/BMI tersebut di deportasi karena melakukan tindak pelanggaran keimigrasian di Malaysia. Pemerintah secara rutin melakukan deportasi dari Tawau ke Nunukan dengan menggunakan kapal fery (minimal sekali dalam sebulan) dengan jumlah depotan lebih dari 100 orang per pemulangan." ${ }^{30}$

Pernyataan di atas menunjukkan jumlah yang cukup signifikan untuk WNI/BMI yang dideportasi hingga berjumlah 6.014 orang. Peneliti mencoba mengaitkan jumlah WNI/BMI deportasi tersebut dengan data yang ditemukan sebelum ke Sabah Malaysia, yakni BP3TKI Nunukan. Data dari KRI Tawau dan BP3TKI Nunukan memiliki kesesuaian. Data yang diperoleh di BP3TKI Nunukan, sebagai berikut:

Tabel 5.7 TKI/WNI Deportasi Berdasarkan Jenis Kelamin dan Jenis Dokumen

\begin{tabular}{|r|r|r|r|r|r|r|r|r|}
\hline \multirow{2}{*}{ No } & \multirow{2}{*}{ Thn } & \multicolumn{3}{|c|}{ Deportasi } & \multicolumn{4}{c|}{ Jenis Dokumen } \\
\cline { 3 - 9 } & & L & \multicolumn{1}{c|}{ P } & Jml & Ilegal & P TKI & P Umum & PLB \\
\hline 1 & 2012 & 2433 & 703 & 3136 & 2.001 & 369 & 640 & 126 \\
\hline 2 & 2013 & 2355 & 512 & 2867 & 1.620 & 433 & 712 & 102 \\
\hline 3 & 2014 & 2797 & 846 & 3643 & 2.539 & 395 & 650 & 62 \\
\hline 4 & 2015 & 4365 & 1654 & 6019 & 4.091 & 684 & 1153 & 91 \\
\hline \multicolumn{2}{|c|}{ Jumlah } & 11.950 & 3.715 & 15.665 & 10.251 & 1.881 & 3.155 & 381 \\
\hline
\end{tabular}

Sumber: BP3TKI Nunukan (2016)

${ }^{30}$ Ibid. 
Data di atas menunjukkan jumlah TKI/WNI yang dideportasi dari Malaysia sejak tahun 2012 hingga 2015 cukup signifikan hingga mencapai 15.665 orang dengan 10.251 orang diantaranya ilegal. Jika dipersentasekan maka 65,43\% TKI yang dideportasi adalah TKI ilegal. Hal ini bisa disebabkan banyak faktor, termasuk TKI non-prosedural.

Grafik 5.3 TKI/WNI Deportasi dari Malaysia 2012-2015

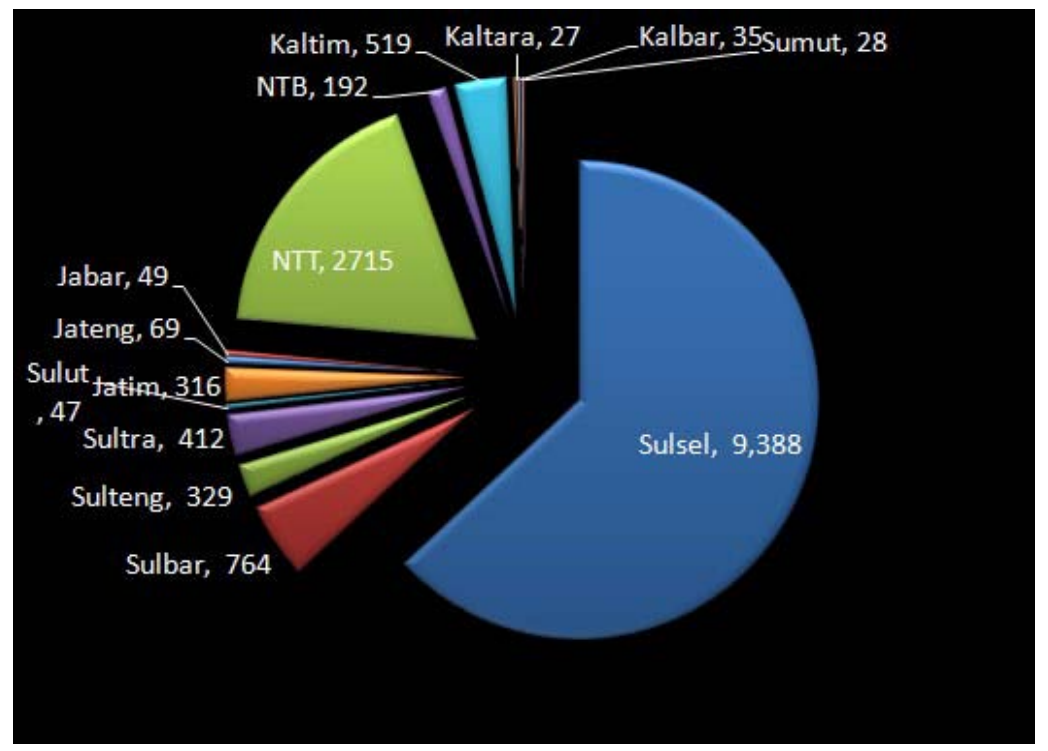

Sumber: BP3TKI Nunukan (2016)

Tabel 5.8 TKI/WNI Deportasi Berdasarkan Asal Daerah

\begin{tabular}{|c|c|c|c|c|c|c|c|c|c|c|c|c|c|c|}
\hline \multirow{2}{*}{ Th } & \multicolumn{2}{|c|}{ Sulsel } & \multicolumn{2}{|c|}{ Sulbar } & \multicolumn{2}{|c|}{ Sulteng } & \multicolumn{2}{|c|}{ Sultra } & \multicolumn{2}{|c|}{ Sulut } & \multicolumn{2}{|c|}{ Jatim } & \multicolumn{2}{|c|}{ Jateng } \\
\hline & $\mathrm{T}$ & $\%$ & $\mathrm{~T}$ & $\%$ & $\mathrm{~T}$ & $\%$ & $\mathrm{~T}$ & $\%$ & $\mathrm{~T}$ & $\%$ & $\mathrm{~T}$ & $\%$ & $\mathrm{~T}$ & $\%$ \\
\hline 2012 & 1884 & 60 & 177 & 5.6 & 81 & 2.6 & 100 & 3.2 & 13 & 0.4 & 89 & 2.9 & 21 & 0.7 \\
\hline 2013 & 1352 & 47.1 & 208 & 7.1 & 97 & 3.4 & 13 & 0.5 & 5 & 0.2 & 5 & 0.2 & 10 & 0.4 \\
\hline 2014 & 2302 & 63.2 & 151 & 4.1 & 57 & 1.6 & 113 & 3.1 & 12 & 0.3 & 85 & 2.3 & 16 & 0.4 \\
\hline 2015 & 3850 & 64 & 228 & 3.8 & 94 & 1.6 & 186 & 3.0 & 17 & 0.3 & 137 & 2.3 & 22 & 0.4 \\
\hline & 9388 & 60 & 764 & 4.9 & 329 & 2.6 & 412 & 2.6 & 47 & 0.3 & 316 & 2.0 & 69 & 0.4 \\
\hline
\end{tabular}




\begin{tabular}{|c|c|c|c|c|c|c|c|c|c|c|c|c|c|c|}
\hline \multirow{2}{*}{ Th } & \multicolumn{2}{|c|}{ Jabar } & \multicolumn{2}{|c|}{ NTT } & \multicolumn{2}{|c|}{ NTB } & \multicolumn{2}{|c|}{ Kaltim } & \multicolumn{2}{|c|}{ Kaltara } & \multicolumn{2}{|c|}{ Kalbar } & \multicolumn{2}{|c|}{ Sumut } \\
\hline & $\mathrm{T}$ & $\%$ & $\mathrm{~T}$ & $\%$ & $\mathrm{~T}$ & $\%$ & $\mathrm{~T}$ & $\%$ & $\mathrm{~T}$ & $\%$ & $\mathrm{~T}$ & $\%$ & $\mathrm{~T}$ & $\%$ \\
\hline 2012 & 5 & 0.2 & 539 & 17.2 & 39 & 1.2 & 161 & 5.1 & 0 & 0 & 8 & 0.3 & 3 & 0.09 \\
\hline 2013 & 5 & 0.2 & 500 & 17.4 & 0 & 0 & 0 & 0 & 0 & 0 & 0 & 0 & 0 & 0 \\
\hline 2014 & 20 & 0.6 & 648 & 17.8 & 63 & 1.7 & 118 & 3.2 & 18 & 0.5 & 9 & 0.3 & 9 & 0.25 \\
\hline 2015 & 19 & 0.3 & 1028 & 17.1 & 90 & 1.5 & 240 & 4 & 9 & 0.1 & 18 & 0.3 & 16 & 0.27 \\
\hline & 49 & 0.3 & 2715 & 17.3 & 192 & 1.2 & 519 & 3.3 & 27 & 0.1 & 35 & 0.2 & 28 & 0.18 \\
\hline
\end{tabular}

Sumber: BP3TKI Nunukan

Data BP3TKI Nunukan di atas memberikan informasi bahwa sebagian besar TKI/WNI yang di deportasi dari Sabah Malaysia dalam kurun waktu 2012-2015 adalah warga Sulawesi Selatan. Angka deportasi mencapai 9.388 orang. Sebagian besar TKI/WNI yang dideportasi tanpa dokumen/ilegal. Rata-rata persentase warga Sulsel yang dideportasi dalam 4 tahun terakhir yakni 60\% jika dibandingkan asal daerah lain. Maka TKI/WNI yang ilegal asal Sulsel juga berkisar persentase demikian. Hal ini sangat mengkhawatirkan, namun tidak mendapatkan sorotan media massa, sehingga kasus ini seolah-olah dikesampingkan. Sigit Triwibawanto, Kepala Seksi Perlindungan BP3TKI Nunukan memberi tanggapan:

"Besarnya jumlah TKI ilegal tidak terlepas dari kondisi geografis Nunukan sebagai pulau terluar/perbatasan yang medukung terjadinya hal ini. Setiap hari di pelabuhan saja saat kapal datang kami biasa melihat ratusan orang dari Indonesia menuju Malaysia. Tentunya kami berprasangka baik bahwa mereka ada urusan di Malaysia, tetapi tujuan orang tidak ada yang tahu. Sedangkan TKI/WNI yang telah deportasi hanya 10-15 orang diantaranya yang mau pulang kampung, yang tidak pulang kampung diterima keluarganya. Sehingga kami merancang program Poros 
Perbatasan untuk membuka kesempatan masuk kembali ke Malaysia dengan jalur prosedural." 31

Pernyataan di atas menyiratkan bahwa BP3TKI Nunukan menyadari bahwa kondisi geografisnya yang rentan sebagai transit TKI ilegal, namun kewenangan untuk mencegah TKI ilegal untuk menyeberang ke Malaysia tidak dimiliki. Sehingga BP3TKI Nunukan hanya bersifat penindakan pasca ditangkapnya TKI ilegal di Sabah Malaysia dan dideportasi. Setelah TKI di deportasi juga menimbulkan masalah baru karena hanya sebagian kecil yang ingin pulang kampung, sedangkan lainnya memilih untuk menetap di Nunukan, dan berpotensi untuk menjadi TKI ilegal lagi, sehingga dibuatlah program poros perbatasan sebagai salah satu solusi dari BP3TKI Nunukan dengan melibatkan berbagai instansi terkait.

Tanggapan dari pemerintah Provinsi Sulawesi Selatan sebagai daerah asal TKI/WNI yang dideportasi dan termasuk TKI ilegal menyatakan bahwa kejadian tersebut sudah teridentifikasi oleh pemerintah daerah, namun belum ada tindakan sampai saat ini. Andi Marzuki Wadeng, Ketua Komisi E DPRD Provinsi Sulawesi Selatan mengemukakan:

"Saat periode 2004-2009 saya di DPRD Provinsi Sulawesi Selatan, tim yang terdiri dari anggota Komisi E yakni pak Aji Padindang (Ketua Komisi), pak Adil Patu, pak Ramli Rewa dan saya didampingi Sahri Tajuddin, Wakil Kadisnaker Sulsel melakukan perjalanan dengan menempuh rute Makassar-Kuala Lumpur-Kota Kinabalu-Sandakan-Tawau-Nunukan. Kami menemukan bahwa di Tawau ada penampungan bagi orang Bugis yang akan dipekerjakan di Perkebunan Sawit. Sedangkan di Nunukan kami diperlihatkan jalur formal (resmi) dan jalur tikus. Hasil kunjungan

\footnotetext{
${ }^{31}$ Wawancara dengan Sigit Triwibawanto, Kepala Seksi Perlindungan dan Pemberdayaan BP3TKI Nunukan, 23 Mei 2016 di Kantor BP3TKI Nunukan
} 
kami pada waktu itu merekomendasikan bahwa semua tenaga kerja agar dilengkapi dokumen, menyediakan tenaga kerja yang siap dipekerjakan dan memberangkatkan yang punya keahlian dan dibutuhkan. Kunjungan tersebut menghasilkan himbauan untuk memperketat pengawasan bagi warga Sulsel ke sana dan di evaluasi pelaksanaannya." ${ }^{32}$

Pernyataan di atas menunjukkan bahwa pemerintah provinsi Sulawesi Selatan telah menaruh perhatian terhadap penempatan TKI asal Sulsel ke Sabah Malaysia. Terhitung sejak dilaksanakannya peninjauan tersebut 10 tahun yang lalu hingga saat ini permasalahan TKI ilegal belum ada tindakan yang efektif. Oleh karena itu dibutuhkan sikap yang lebih tegas dari pemerintah provinsi Sulawesi Selatan untuk turut serta dalam mencari solusi bagi warganya melalui koordinasi dengan pemerintah daerah Kabupaten Nunukan.

Selain pemerintah Indonesia melalui instansi terkait yang berperan dalam penempatan dan perlindungan TKI/PMI. Pemerintah Malaysia juga memiliki seperangkat lembaga yang menangani pekerja asing, termasuk pekerja migran asal Sulawesi Selatan di Sabah, Malaysia. Lembaga yang diberi wewenang adalah Jabatan Tenaga Kerja (JTK) Sabah. Lembaga ini adalah salah satu jabatan di Sabah yang bernaung di bawah Kementerian Sumber Manusia, Malaysia. Jabatan ini bertanggungjawab langsung kepada Kementerian Sumber Manusia, Malaysia dalam menjalankan tugas pengelolaan dan penegakan hukum ketenagakerjaan di Sabah. Visi JTK Sabah menjadi penggerak utama di dalam menjana pengurusan sumber manusia yang cemerlang di sektor swasta. Misi JTK Sabah yakni membangun masyarakat industri yang produktif, bermaklumat, berdisiplin,

\footnotetext{
${ }^{32}$ Wawancara dengan Drs. H. Andi Marzuki Wadeng, Ketua Komisi E DPRD Provinsi Sulawesi Selatan, 25 April 2016 di Gedung DPRD Provinsi Sulsel
} 
penyayang serta responsif kepada perubahan-perubahan persekitaran dalam suasana perburuhan. ${ }^{33}$

Objektif (tujuan) JTK Sabah yakni: (1) melindungi kepentingan dan memajukan kebajikan masyarakat industri; (2) mengutamakan dan mengekalkan peluang-peluang pekerjaan kepada warga negara Malaysia; (3) membantu industri dalam meningkatkan daya saing bagi menghadapi cabaran-cabaran globalisasi; dan (4) mewujudkan tenaga kerja dan majikan yang berpengetahuan dalam hal perburuhan dan undang-undang buruh demi membina suasana perburuhan yang kondusif bagi pembangunan perindustrian dan pelaburan. ${ }^{34}$

Lembaga yang mewakili pemerintah di negara penempatan dalam menjalankan visi, misi dan tujuannya tentu berorientasi terhadap optimalisasi penggunakan pekerja tempatan (tenaga kerja lokal) sebagai bagian dari kebijakan ketenagakerjaannya untuk memberikan lapangan kerja bagi warga negaranya. Sehingga pekerja asing patut menyadari posisinya di negara penempatan. Suhaili bin Ismail, Senior Assistant Director, Pejabat Tenaga Kerja Tawau, Jabatan Tenaga Kerja Sabah, Malaysia mengungkapkan:

"Setiap majikan yang ingin mengambil pekerja asing. Perlu mengambil pekerja tempatan terlebih dahulu di portal Jobs Malaysia. Tempo masa 2 minggu (14 hari) bagi majikan untuk menunggu, jika tiada applicant dari pekerja tempatan barulah job itu boleh dibuka kepada pekerja asing. Bila di tengok sektor construction (konstruksi) dan plantation (perkebunan) termasuk ke

\footnotetext{
${ }^{33}$ Jabatan Tenaga Kerja Sabah, n.d., Brosur Sepintas Lalu Jabatan Tenaga Kerja Sabah, Malaysia: Kementerian Sumber Manusia.

${ }^{34}$ Ibid.
} 
sektor yang 3D (dirty, dangerous dan difficult) tidak disukai oleh pekerja tempatan"35

Pernyataan di atas menguraikan bahwa pemerintah Malaysia sebagai negara tujuan bagi TKI/PMI tetap memprioritaskan tenaga kerjanya untuk medapatkan pekerjaan. Sedangkan untuk pekerja asing diberikan prioritas setelah pekerja lokal (Malaysia). Sektor konstruksi dan perkebunan yang masuk dalam kategori 3D yakni dirty, dangerous dan difficult (kotor, berbahaya dan sulit) diberikan kepada pekerja asing karena tidak diminati pekerja lokal. Hal ini menjelaskan mengapa pekerja migran asal Sulawesi Selatan 'dibutuhkan' oleh pemerintah Malaysia untuk bekerja di Sabah pada sektor perkebunan dikarenakan lapangan kerja ini tidak diminati pekerja lokal. Walaupun demikian, pemerintah provinsi Sulawesi Selatan perlu melakukan pengawasan terhadap sektor ini termasuk pada kategori 3D.

Fungsi dan aktiviti (tugas) utama JTK Sabah dijalankan sebagai upaya untuk mencapai tujuan. Fungsi utama sebagai berikut: (a) fungsi manajemen (pengurusan): (1) perkhidmatan; (2) pentadbiran; kewangan; dan (4) penyelidikan dan perancangan. (b) fungsi operasional: (1) penguatkuasaan Undang-undang Buruh (enforcement of Labour Laws); dan (2) perkhidmatan pekerjaan (employment services division). ${ }^{36}$ Suhaili bin Ismail, Senior Assistant Director, Pejabat Tenaga Kerja Tawau, Jabatan Tenaga Kerja Sabah, Malaysia menjelaskan:

\footnotetext{
${ }^{35}$ Wawancara dengan Suhaili bin Ismail, Senior Assistant Director, Pejabat Tenaga Kerja Tawau, Jabatan Tenaga Kerja Sabah, Kementerian Sumber Manusia, Malaysia, 27 Mei 2016 di Wisma Persekutuan Tawau.

${ }^{36} \mathrm{lbid}$.
} 
"Policy (kebijakan) bagi pekerja asing ialah Sabah Labour Ordinance yang diberlakukan kepada seluruh yang bekerja di wilayah Sabah Malaysia" ${ }^{37}$

Pernyataan di atas menegaskan bahwa kebijakan utama yang dirujuk untuk mengelola pekerja asing di Sabah yakni Sabah Labour Ordinance. Kebijakan yang dikuatkuasakan (ditegakkan) oleh JTK Sabah, antara lain: (1) Ordinan Buruh (Sabah Bab 67), (2) Akta Pampasan Pekerja 1952 dan Peraturan-Peraturan Pampasan Pekerja termasuk Perintah Pampasan Pekerja Asing 1998; (3) Akta Agensi Pekerjaan Swasta 1952; (4) Akta Majlis Penetapan Gaji 1947; (5) Akta Maklumat Pekerjaan 1953; (6) Akta Keselamatan dalam Negeri (Peraturan Pendaftaran Buruh) 1960 dan (7) Konvesyen-Konvesyen Pertubuhan Buruh Antarbangsa (ILO) yang diiktiraf. ${ }^{38}$

Berdasarkan pemaparan di atas dapat dipahami bahwa pemerintah Indonesia melalui perwakilannya di Sabah Malaysia yakni Konsulat Republik Indonesia Tawau turut menjalankan UU No. 39 Tahun 2004 sesuai dengan garis koordinasi dengan Kementerian Luar Negeri RI di Indonesia. Fakta yang ditemukan di lapangan menunjukkan bahwa terjadi deportasi WNI/TKI kembali ke Indonesia melalui Nunukan sebagai bagian dari peran pemerintah untuk melindungi hak-hak WNI/TKI. Setelah perwakilan Indonesia memfasilitas kepulangan TKI kembali ke Indonesia, seyogyanya pemerintah daerah asal TKI turut ambil bagian dalam upaya perlindungan warganya.

\footnotetext{
${ }^{37}$ Wawancara dengan Suhaili bin Ismail, Senior Assistant Director, Pejabat Tenaga Kerja Tawau, Jabatan Tenaga Kerja Sabah, Kementerian Sumber Manusia, Malaysia, 27 Mei 2016 di Wisma Persekutuan Tawau.

${ }^{38}$ Jabatan Tenaga Kerja Sabah, n.d., loc. cit.
} 
Selain pemerintah Indonesia, pemerintah di negara penempatan dalam hal ini pemerintah wilayah Sabah Malaysia memiliki peran yang signifikan terhadap pemenuhan hak-hak TKI, utamanya hak-hak yang menyangkut hak-hak TKI yang ditanggung oleh majikan/pengguna yang mempekerjakan TKI. Pemaparan di atas telah jelas menjelaskan posisi pekerja asing, termasuk TKI/PMI asal Sulsel yang bekerja di Malaysia berada pada kategori pekerjaan 3D. Sehingga potensi terjadinya hal-hal yang tidak diinginkan terhadap TKI perlu diantisipasi lebih awal.

\subsubsection{Interaksi Pemerintah dan Swasta}

Majikan/pengguna yang mempekerjakan pekerja migran asal Sulawesi Selatan di Malaysia merupakan perkebunan sawit yang berstatus badan usaha milik negara (pemerintah) dan badan usaha swasta. Konsulat RI di Tawau mendata perusahaan di Malaysia yang mempekerjakan TKI/PMI di wilayah kerjanya sebagai berikut:

Tabel 5.9 Senarai Syarikat di Wilayah Kerja KRI Tawau (Tawau)

\begin{tabular}{|c|c|c|}
\hline No. & Nama Syarikat/Ladang & Alamat \\
\hline 1 & Benta Wawasan Sdn. Bhd. & $\begin{array}{l}\text { TB } 9131 \text { \& } 9132 \text { Perdana Square, } \\
\text { Batu } 3^{1 / 2} \text { Jalan Apas Tawau }\end{array}$ \\
\hline 2 & Ikut Maju Sdn. Bhd. & $\begin{array}{l}2^{\text {nd }} \text { Floor Tb 580, Lot No. } 6 \text { Fajar } \\
\text { Complex, Jalan Haji Karim, Tawau, } \\
\text { Sabah, } 91000\end{array}$ \\
\hline 3 & IOI Baturong 3 & - \\
\hline 4 & Kalabakan Plywood Sdn. Bhd. & PO Box 983, 91008 Tawau, Sabah \\
\hline 5 & Kemabong Sdn. Bhd. & $\begin{array}{l}2145 \text { Jln. Habib Hussin, 91000, } \\
\text { Tawau, PO Box 531, 91008, Tawau } \\
\text { Sabah }\end{array}$ \\
\hline 6 & Khas Permata Sdn. Bhd. & $\begin{array}{l}\text { Mile 3, Tanjung Batu Laut, 91020, } \\
\text { Tawau Sabah }\end{array}$ \\
\hline 7 & KL Kepong (Sabah) Sdn. Bhd. & $\begin{array}{l}\text { Jln. Tawau-Kunak, Sigalong Golf } \\
\text { Club, 91009, Tawau, Sabah }\end{array}$ \\
\hline 8 & QL Plantation Sdn. Bhd. & $\begin{array}{l}\text { TB } 50 \text { \& 52, Mile 5, Apas Road, } \\
\text { 91000, Tawau PO Box No. 61651, } \\
\text { 91026, Tawau, Sabah }\end{array}$ \\
\hline 9 & Rajang Plywood Sdn. Bhd. & $\begin{array}{l}\text { TB. } 4327 \text { Blok 31, Fajar Kompleks, } \\
\text { 91000, Tawau, Sabah }\end{array}$ \\
\hline
\end{tabular}




\begin{tabular}{|c|l|l|}
\hline 10 & Sabah Softwood Bhd. & $\begin{array}{l}\text { Brumas Camp, PS 60966, 91019 } \\
\text { Tawau, Sabah }\end{array}$ \\
\hline 11 & Sawit Kinabalu & $\begin{array}{l}\text { Mile 2 } \\
28,2 \text { Jalan Kuhara, Locked Bag } \\
\text { 28, 91009, Tawau }\end{array}$ \\
\hline 12 & $\begin{array}{l}\text { Sime Darby (Sabah) Plantation } \\
\text { Sdn. Bhd. }\end{array}$ & $\begin{array}{l}\text { Km. 18, Jalan Merotai Bombalai PO } \\
\text { Box 135, 91007, Tawau, Sabah }\end{array}$ \\
\hline 13 & Srijaya Industri & $\begin{array}{l}\text { Tingkat 2, Bangunan TSH TB9 Km. } \\
\text { 7, Apas Road, 91000, Tawau }\end{array}$ \\
\hline 14 & Tamaco Plantations Sdn. Bhd. & - \\
\hline 15 & Teck Guan Holdings Sdn. Bhd. & $\begin{array}{l}\text { Teck Guan Regency 318 Jln. St. } \\
\text { Patrick, Off Jln. Bunulu PO Box 33, } \\
91007, \text { Tawau }\end{array}$ \\
\hline 16 & Tsh Plantations Berhad & $\begin{array}{l}\text { Bangun TSH, TB 9 Apas Road, } \\
91000, \text { Tawau }\end{array}$ \\
\hline 17 & Usahawan Borneo & - \\
\hline 18 & Yuwang Plantations Sdn. Bhd. & - \\
\hline
\end{tabular}

Sumber: Konsulat RI Tawau (2016)

Tenaga Kerja Indonesia merupakan penyokong bagi pertumbuhan ekonomi di Tawau, terutama perekonomian yang digerakkan oleh ladangladang kelapa sawit yang dimiliki oleh pemerintah Malaysia maupun swasta. Dian Ratri Astuti, Kepala Kanselerai/Fungsi Pensosbud KRI Tawau menerangkan:

"Penduduk daerah Tawau terdiri dari suku Melayu, Cina, Bugis, Suluk, Tidung, Bajau, Bolongan, Banjar, Buton, Kadazan, Arab, India, Murut, Orang Sungai dan sebagainya. Kehadiran tenaga kerja asing di Tawau terutama dari Indonesia dan Filipina merupakan kontributor utama pesatnya pertumbuhan penduduk di daerah Tawau. Diperkirakan tenaga kerja asing di Tawau 70\% merupakan Warga Negara Indonesia dan 30\% Warga Negara Filipina. Orang Indonesia yang bekerja di Tawau berasal dari suku Bugis dan Timor. Para pendatang ini telah mendukung pesatnya pertumbuhan ekonomi di daerah ini. Tawau mendapat julukan sebagai 'Bumi Peladang', yang sebagian besar wilayahnya merupakan kawasan perladangan. Ladang-ladang kelapa sawit ini, umumnya dimiliki oleh Government Link Company (GLC) seperti Sime Darby Corporation, Sabah Softwood Sdn. Bhd., Borneo Samudera (Sawit) dan Felda."39

Pernyataan di atas menjelaskan bahwa Tawau dan Bugis (TKI asal

Sulsel) telah memiliki hubungan yang sangat erat secara kultural. Hal ini

\footnotetext{
${ }^{39}$ Wawancara dengan Dian Ratri Astuti, Kepala Kanselerai/Fungsi Pensosbud KRI Tawau, 24 Mei 2016 di Kantor KRI Tawau.
} 
dikarenakan orang Bugis di Tawau telah menjadi pendatang secara turun temurun, sehingga daya tarik bagi warga Sulsel untuk bekerja di Tawau khususnya dan Sabah Malaysia secara umum semakin kuat. Government Link Company (GLC) merupakan perusahaan pemerintah sebagaimana PT. PN (Perkebunan Nasional) di Indonesia.

Kedutaan Besar Republik Indonesia (KBRI) di Kuala Lumpur merilis data bahwa sektor perkebunan (plantation) menjadi sektor yang diminati oleh TKI dengan jumlah pekerja sebanyak 550.422 orang. KJRI Kota Kinabalu merupakan perwakilan yang paling banyak mendata TKI sektor perkebunan di wilayah kerjanya, diikuti KRI Tawau, KBRI Kuala Lumpur, KJRI Kuching, KJRI Johor Bahru dan KJRI Penang. Selain itu, TKI juga bekerja di sektor PLRT (domestic worker), manufaktur dan konstruksi. Data selengkapnya sebagai berikut:

Tabel 5.10 Data Tenaga Kerja Indonesia di Malaysia

\begin{tabular}{|c|c|c|c|c|c|c|c|c|}
\hline \multirow[b]{2}{*}{ No } & \multirow[b]{2}{*}{ Sektor } & \multicolumn{6}{|c|}{ KBRI/KJRI } & \multirow[b]{2}{*}{ Total } \\
\hline & & $\begin{array}{l}\text { Kuala } \\
\text { Lumpur }\end{array}$ & $\begin{array}{l}\text { Johor } \\
\text { Bahru }\end{array}$ & Penang & Kuching & $\begin{array}{c}\text { Kota } \\
\text { Kinabalu }\end{array}$ & Tawau & \\
\hline 1. & Oils & & 15 & & 58 & 60 & & 133 \\
\hline 2. & PLRT & 167.605 & 56.229 & 8.057 & 790 & 5.024 & 2.425 & 240.130 \\
\hline 3. & Construction & 144.347 & 469 & 11.194 & 2.030 & 8.524 & 11.009 & 177.573 \\
\hline 4. & Manufacturing & 121.835 & 11.299 & 11.730 & 15.661 & 6.407 & 10.752 & 177.684 \\
\hline 5. & Services & 20.190 & 18.589 & 7.391 & 952 & 8.065 & 3.849 & 59.036 \\
\hline 6. & Plantation & 86.979 & 41.260 & 3.168 & 68.562 & 239.589 & 110.864 & 550.422 \\
\hline 7. & Farming & 53.852 & - & - & - & - & - & 53.852 \\
\hline 8. & $\begin{array}{l}\text { Peternakan/ } \\
\text { Perikanan }\end{array}$ & 265 & 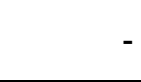 & 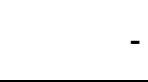 & - & - & - & 265 \\
\hline 9. & Lain-Lain & - & 24.564 & 1.296 & 227 & 825 & 20.749 & 47.661 \\
\hline & Total & 595.073 & 152.425 & 42.836 & 88.280 & 268.494 & 159.648 & 1.306 .756 \\
\hline & Jumlah WNI & 1.260 .270 & 353.628 & 54.635 & 230.758 & 454.035 & 237.721 & 2.591 .447 \\
\hline
\end{tabular}

Sumber: KBRI Kuala Lumpur (2013)

Berdasarkan data di atas 110.864 dari 550.422 orang atau $20 \%$ dari pekerja migran Indonesia di sektor perkebunan berada dalam wilayah 
kerja KRI Tawau. Sedangkan sebagian wilayah Sabah juga berada dalam wilayah KJRI Kota Kinabalu, sehingga jika keduanya ditambahkan maka 350.453 dari 550.422 orang atau $63,7 \%$ dari pekerja di sektor perkebunan berada di wilayah Sabah Malaysia. Hal ini semakin menguatkan perlunya advokasi terhadap pemenuhan hak-hak TKI di sektor perkebunan.

Konsulat RI Tawau juga melakukan pendataan terhadap pekerja migran Indonesia di wilayah kerjanya, sebagai berikut:

Tabel 5.11 Data Jumlah Buruh (Pekerja) Migran Indonesia dan Tanggungan di Wilayah Kerja Konsulat RI Tawau

\begin{tabular}{|l|l|c|c|c|c|}
\hline No & \multicolumn{1}{|c|}{ Nama Ladang } & L & P & T/I & TIA \\
\hline 1 & Felda Global VPM Sahabat 12 & 121 & 23 & 0 & 0 \\
\hline 2 & Serijaya Industri Sdn. Bhd. & 219 & 121 & 0 & 0 \\
\hline 3 & Pontian United Sdn. Bhd. & 445 & 313 & 219 & 0 \\
\hline 4 & Timor Enterprise Sdn. Bhd. & 341 & 170 & 94 & 358 \\
\hline 5 & Fuesb Estet Danum & 106 & 27 & 11 & 9 \\
\hline 6 & Kwantas Plantations Sdn. Bhd. & 432 & 181 & 48 & 126 \\
\hline 7 & IOI Plantation Services Sdn. Bhd. & 4.823 & 886 & 305 & 547 \\
\hline 8 & Lamsoon Plantations Sdn. Bhd. & 330 & 206 & 2 & 20 \\
\hline 9 & JC Jaya Plantations Sdn. Bhd. & 11 & 1 & 10 & 6 \\
\hline 10 & Ladang Tengah Nipah & 114 & 40 & 1 & 19 \\
\hline 11 & Felda Global VPM Sdn. Bhd. & 4.631 & 1454 & 148 & 643 \\
\hline & $\quad$ Jumlah & 11.573 & 3.422 & 838 & 1.728 \\
\hline
\end{tabular}

Ket: $\mathrm{L}$ = Laki-Laki; $\mathrm{P}=$ Perempuan; $\mathrm{T}$ = Tanggungan; I = Istri; A=Anak

Sumber: Konsulat RI Tawau (2016)

Data di atas merupakan data yang didapatkan dari KRI Tawau.

Data tersebut memang belum mencakup keseluruhan ladang di wilayah kerja KRI Tawau, tetapi setidaknya menjadi gambaran persebaran TKI di ladang-ladang pemerintah maupun swasta. Ladang Felda Global VPM mempekerjakan 6.085 orang, sedangkan ladang IOI Plantation mempekerjakan 5.709 orang. Jumlah keseluruhan yang terdata yakni 14.955 pekerja di luar tanggungan, jika dibandingkan dengan data KBRI 
Kuala Lumpur sebanyak 110.864 orang di wilayah Tawau berarti hanya $13,5 \%$ yang terdata.

KRI Tawau senantiasa memperbaharui data pekerja migran Indonesia di wilayah kerjanya dengan melakukan pemantauan secara langsung maupun tidak langsung. Pemantauan secara langsung dilakukan dengan mengunjungi ladang. Prakoso Wicaksono, Fungsi Ekonomi dan Protokol Kekonsuleran KRI Tawau menjelaskan:

"Beberapa hasil kunjungan KRI Tawau ke ladang diantaranya kunjungan ke Ladang Muis Melewar pada tanggal 14 Maret 2016 oleh Fungsi Sosbud KRI Tawau. Ladang ini berjarak kurang lebih $65 \mathrm{Km}$ dari pusat kota Tawau. Perjalanan melalui jalan raya dan gravel, ditempuh dalam waktu 1 jam 30 menit. Ladang Muis Melewar ini memiliki luas 5000 are. Dengan 268 (dua ratus enam puluh delapan pekerja) laki-laki dan wanita yang 95\% berasal dari Indonesia, selebihnya dari Filipina. Kunjungan lainnya juga dilakukan ke ladang Rajang Plywood Sabah pada 18 Maret 2016 oleh Staf Teknis Imigrasi KRI Tawau. Ladang ini memiliki 600 orang pekerja TKI yang terdiri dari 420 orang pekerja laki-laki dan 180 orang pekerja perempuan kesemuanya mempunyai paspor dan izin tinggal yang masih berlaku di Sabah, Malaysia."

Pernyataan di atas memberikan informasi bahwa KRI Tawau memiliki kegiatan untuk turun meninjau langsung ke ladang untuk melihat kondisi TKI. Informasi yang didapatkan dari kunjungan di dua ladang tersebut yakni ladang Muis Melewar mempekerjakan 268 orang dengan 95\% diantaranya adalah TKI, sedangkan ladang Rajang Plywood mempekerjakan 600 orang. Kehadiran KRI Tawau di ladang merupakan bagian dari fungsi pengawasan terhadap majikan, diharapkan dengan intensifnya komunikasi secara langsung, maka permasalahan yang

\footnotetext{
${ }^{40}$ Wawancara dengan Prakoso Wicaksono, Fungsi Ekonomi dan Protokol Kekonsuleran/Vice Consul KRI Tawau, 24 Mei 2016 di Kantor KRI Tawau.
} 
menimpa TKI dapat disampaikan segera kepada perwakilan RI dalam hal ini KRI Tawau untuk wilayah Tawau dan sekitarnya.

Perlindungan WNI/TKI merupakan bagian dari upaya pemenuhan hak-hak TKI. Dian Ratri Astuti, Kepala Kanselerai/Fungsi Pensosbud KRI Tawau menerangkan:

"Setiap WNI yang berada di Malaysia dapat meminta bantuan perlindungan kepada kami (KRI Tawau). Bantuan yang diberikan dapat berupa konsultasi, advokasi dan mediasi. Kami (KRI Tawau) akan membantu menyelesaikan kasus WNI yang bermasalah dengan majikan, agensi pekerjaan, atau pihak lainnya. Permasalahan yang dihadapi oleh WNI dapat disampaikan kepada kami (KRI Tawau) melalui telepon, faks, SMS, ataupun email, maupun datang langsung ke kantor. Namun demikian pada prinsipnya bantuan perlindungan yang diberikan adalah mengikut ketentuan hukum yang berlaku di negara setempat dan juga kaedah hukum internasional."

Pernyataan di atas mencerminkan sikap KRI Tawau yang pro terhadap perlindungan kepada WNI, termasuk TKI, serta menjadi jembatan penyelesaian masalah antara TKI dengan majikan/pengguna. KRI Tawau menerima pengaduan dari WNI/TKI melalui berbagai saluran untuk memudahkan akses terhadap perlindungan.

KRI Tawau melalui berbagai saluran pengaduan yang dibuka menerima kasus WNI/TKI bermasalah, sebagai berikut:

Tabel 5.12 Kasus WNI/TKI Bermasalah 2014 dan 2015

\begin{tabular}{|c|l|c|c|}
\hline No & \multicolumn{1}{|c|}{ Jenis Kasus } & Tahun 2014 & Tahun 2015 \\
\hline 1 & Tidak Dibayar Gaji & 21 & 27 \\
\hline 2 & PHK Sepihak & 75 & 58 \\
\hline 3 & Eksploitasi Kerja/Potongan Gaji & 32 & 20 \\
\hline 4 & Penipuan/Trafficking & 5 & 3 \\
\hline 5 & Keimigrasian & 19 & 17 \\
\hline 6 & Kriminal/Kekerasan/KDRT & 5 & 8 \\
\hline
\end{tabular}

\footnotetext{
${ }^{41}$ Wawancara dengan Dian Ratri Astuti, Kepala Kanselerai/Fungsi Pensosbud KRI Tawau, 24 Mei 2016 di Kantor KRI Tawau.
} 


\begin{tabular}{|c|l|c|c|}
\hline 7 & Terlantar/Sakit/Depresi & 5 & 2 \\
\hline 8 & Kecelakaan Kerja & 21 & 5 \\
\hline 9 & Lari dari Majikan & 1 & 0 \\
\hline \multicolumn{2}{|c|}{ Jumlah } & 184 & 140 \\
\hline
\end{tabular}

Sumber: Konsulat RI Tawau (2016)

Data di atas menunjukkan terjadi penurunan kasus WNI/TKI bermasalah yang dilaporkan ke KRI Tawau. Pengaduan para TKI diselesaikan konsulat RI Tawau dengan memberikan konsultasi dan mediasi antara TKI dengan pihak perusahaan/majikan. Pemaparan pelayanan bantuan kepada WNI/TKI bermasalah, sebagai berikut:

Tabel 5.13 Pelayanan Bantuan kepada WNI/TKI Bermasalah Tahun 2014 dan 2015

\begin{tabular}{|c|l|c|c|}
\hline No & \multicolumn{1}{|c|}{ Jenis Kasus } & Tahun 2014 & Tahun 2015 \\
\hline 1 & $\begin{array}{l}\text { Pemulangan WNI dari Shelter KRI } \\
\text { Tawau }\end{array}$ & 6 & 22 \\
\hline 2 & Konsultasi Ketenagakerjaan & 244 & 206 \\
\hline 3 & Konsultasi Perlindungan & 176 & 113 \\
\hline 4 & Konsultasi Keluarga & 30 & 38 \\
\hline 5 & Bantuan Penguburan Jenazah & 0 & 0 \\
\hline 6 & Bantuan Pemulangan Jenazah & 11 & 9 \\
\hline 7 & Bantuan Perobatan & 4 & 2 \\
\hline 8 & Bantuan Klaim Asuransi/Kematian & 34 & 23 \\
\hline 9 & $\begin{array}{l}\text { Bantuan Penampungan WNI/TKI } \\
\text { Bermasalah }\end{array}$ & 29 & 43 \\
\hline 10 & Bantuan Persidangan & 33 & 2 \\
\hline
\end{tabular}

Sumber: Konsulat RI Tawau (2016)

Data di atas menunjukkan bahwa selama tahun 2015 terjadi penurunan pada sebagian aspek terhadap WNI/TKI bermasalah di KRI Tawau. Dian Ratri Astuti, Kepala Kanselerai/Fungsi Pensosbud KRI Tawau menerangkan:

"Menurunnya kasus WNI/TKI pada tahun 2015 merupakan cerminan efektivitas kerja Satgas Perlindungan WNI/TKI yang telah dijadikan tumpuan dalam penyelesaian permasalahan antara WNI/TKI dengan pihak tempat mereka bekerja. Kami (KRI Tawau) 
secara berkesinambungan memberikan perlindungan dan pelayanan kepada WNI/BMI yang berada di wilayah kerja." ${ }^{42}$

Pernyataan di atas menjelaskan hubungan antara penurunan kasus WNI/TKI dengan efektivitas satuan tugas (satgas) perlindungan WNI/TKI yang dibentuk oleh KRI Tawau. Hal yang diharapkan dari penurunan kuantitas kasus yang ditangani oleh KRI Tawau yakni semakin meningkatnya kualitas pelayanan yang diberikan oleh satgas melalui perluasan jangkauan perlindungan WNI/TKI.

Salah satu hal yang krusial dalam pemenuhan hak-hak TKI adalah pemenuhan hak ekonomi. KRI Tawau memberikan perlindungan atas hak ekonomi tersebut melalui pelayanan pengembalian tuntutan gaji WNI/TKI, sebagai berikut:

Tabel 5.14 Pelayanan Pengembalian Tuntutan Gaji WNI/TKI

\begin{tabular}{|l|l|c|c|}
\hline No. & \multicolumn{1}{|c|}{ Uraian } & Tahun 2014 & Tahun 2015 \\
\hline 1 & Perusahaan/majikan & 68 & 45 \\
\hline 2 & Pekerja yang terlibat & 229 & 89 \\
\hline 3 & $\begin{array}{l}\text { Uang yang dikembalikan } \\
\text { (dalam Ringgit/RM) }\end{array}$ & $379.224,39$ & $309.010,51$ \\
\hline 4 & $\begin{array}{l}\text { Uang yang dikembalikan } \\
\text { dalam Rupiah (1 RM = Rp. } \\
\text { 3.200) }\end{array}$ & 1.327 .285 .365 & 1.081 .536 .185 \\
\hline
\end{tabular}

Sumber: Konsulat RI Tawau (2016)

Data di atas menunjukkan KRI Tawau pada tahun 2015 berhasil memberikan bantuan pelayanan perlindungan pengembalian tuntutan gaji kepada 89 WNI/TKI di wilayah kerja. Sedangkan total uang yang telah dikembalikan kepada WNI/TKI di wilayah kerja sebanyak RM 379.224,39 atau setara dengan Rp. 1.327.285.365. Dian Ratri Astuti, Kepala Kanselerai/Fungsi Pensosbud KRI Tawau menjelaskan lebih lanjut:

\footnotetext{
42 Ibid.
} 
"Jumlah perusahaan/majikan yang dilaporkan menurun, tetapi jumlah pengembalian tuntutan gaji TKI relatif sama. Hal ini menunjukkan bahwa kinerja dari Satgas pelayanan dan perlindungan WNI/TKI telah maksimal dalam upayanya memperjuangkan hak dari TKI yang telah dirugikan serta upaya sosialisasi tanggungjawab dan hak-hak kepada TKI yang disampaikan kepada para perusahaan/majikan telah tepat sasaran dan telah dipatuhi. Selain itu pada tahun 2009 kebijakan pemerintah Malaysia menghentikan kebijakan levy yang telah ditetapkan pada pekerja asing dan telah secara tegas melarang para majikan untuk melakukan pemotongan upah untuk penggantian levy telah mengakibatkan bertambahnya jumlah pengembalian gaji dari TKI."43

Pernyataan di atas menunjukkan bahwa keberhasilan Satgas Perlindungan WNI/TKI dalam memperjuangkan hak dari TKI yang telah dirugikan dapat dilihat dari jumlah dana yang berhasil dikembalikan. Hal ini merupakan salah satu indikator bahwa ekonomi politik kelembagaan di masa penempatan berjalan. Perwakilan pemerintah di negara penempatan memiliki posisi tawar dengan majikan.

Permasalahan yang terjadi pada masa penempatan juga diidentifikasi oleh BP3TKI Makassar sebagai berikut:

Tabel 5.15 Penanganan Kasus BP3TKI Makassar 2012-2015

\begin{tabular}{|c|c|c|c|c|c|c|c|c|c|c|c|c|c|}
\hline \multirow{3}{*}{ No } & \multirow{3}{*}{ Jenis Kasus } & \multicolumn{12}{|c|}{ Tahun } \\
\hline & & \multicolumn{3}{|c|}{2012} & \multicolumn{3}{|c|}{2013} & \multicolumn{3}{|c|}{2014} & \multicolumn{3}{|c|}{2015} \\
\hline & & JK & $\mathrm{S}$ & BS & JK & $\mathrm{S}$ & BS & JK & $\mathrm{S}$ & BS & JK & $\mathrm{S}$ & BS \\
\hline 1 & $\begin{array}{l}\text { Pencarian Ahli } \\
\text { Waris }\end{array}$ & 2 & 2 & 0 & 0 & 0 & 0 & 3 & 3 & 0 & 0 & 0 & 0 \\
\hline 2 & $\begin{array}{l}\text { Klaim } \\
\text { Asuransi }\end{array}$ & 22 & 20 & 2 & 10 & 10 & 0 & 18 & 12 & 4 & 6 & 6 & 0 \\
\hline 3 & $\begin{array}{l}\text { Pengaduan } \\
\text { Penganiayaan }\end{array}$ & 1 & 1 & 0 & 0 & 0 & 0 & 0 & 0 & 0 & 1 & 1 & 0 \\
\hline 4 & $\begin{array}{l}\text { Pemulangan } \\
\text { Jenazah }\end{array}$ & 10 & 10 & 0 & 8 & 8 & 0 & 11 & 9 & 2 & 5 & 5 & 0 \\
\hline 5 & $\begin{array}{l}\text { Permohonan } \\
\text { pemulangan } \\
\text { TKI }\end{array}$ & 1 & 1 & 0 & 3 & 3 & 0 & 1 & 1 & 0 & 4 & 4 & 0 \\
\hline 6 & Pemulangan & 4 & 2 & 2 & 2 & 2 & 0 & 6 & 6 & 0 & 17 & 17 & 0 \\
\hline
\end{tabular}

43 Ibid, 


\begin{tabular}{|c|l|c|c|c|c|c|c|c|c|c|c|c|c|}
\hline & TKI B & & & & & & & & & & & & \\
\hline 7 & $\begin{array}{l}\text { Pemulangan } \\
\text { WNI } \\
\text { bermasalah }\end{array}$ & 1 & 1 & 0 & 1 & 1 & 0 & 2 & 2 & 0 & 0 & 0 & 0 \\
\hline 8 & $\begin{array}{l}\text { Permohonan } \\
\text { bantuan } \\
\text { hukum }\end{array}$ & 1 & 1 & 0 & 0 & 0 & 0 & 3 & 3 & 0 & 0 & 0 & 0 \\
\hline 9 & $\begin{array}{l}\text { Gaji belum } \\
\text { dibayarkan }\end{array}$ & 2 & 2 & 0 & 1 & 1 & 0 & 0 & 0 & 0 & 0 & 0 & 0 \\
\hline & Total & 44 & 40 & 4 & 25 & 25 & 0 & 44 & 36 & 0 & 33 & 33 & 0 \\
\hline
\end{tabular}

Sumber: Diolah dari data BP3TKI Makassar | Keterangan: JK = Jumlah Kasus; $\mathrm{S}=$ Selesai; $\mathrm{BS}=$ Belum Selesai/Proses

Data di atas menunjukkan pekerja migran asal Sulsel selama 4 tahun terakhir mengalami 146 kasus dengan 134 kasus yang selesai pada kategori permasalahan masa penempatan. Kasus yang dialami oleh pekerja migran asal Sulsel di Malaysia setelah disortir dari data di atas, sebagai berikut:

Tabel 5.16 Jumlah Kasus BP3TKI Makassar di Malaysia 2012-2015

\begin{tabular}{|c|l|c|c|c|c|c|}
\hline \multirow{2}{*}{ No } & Jenis Kasus & 2012 & 2013 & 2014 & 2015 & Total \\
\cline { 2 - 6 } 1 & $\begin{array}{l}\text { Pencarian Ahli } \\
\text { Waris }\end{array}$ & 2 & 0 & 3 & 0 & 5 \\
\hline 2 & Klaim Asuransi & 21 & 8 & 14 & 4 & 47 \\
\hline 3 & $\begin{array}{l}\text { Pengaduan } \\
\text { Penganiayaan }\end{array}$ & 0 & 0 & 0 & 0 & 0 \\
\hline 4 & $\begin{array}{l}\text { Pemulangan } \\
\text { Jenazah }\end{array}$ & 6 & 7 & 8 & 3 & 24 \\
\hline 5 & $\begin{array}{l}\text { Permohonan } \\
\text { pemulangan } \\
\text { TKI }\end{array}$ & 1 & 2 & 1 & 1 & 5 \\
\hline 6 & $\begin{array}{l}\text { Pemulangan } \\
\text { TKI B }\end{array}$ & 0 & 0 & 3 & 7 & 10 \\
\hline 7 & $\begin{array}{l}\text { Pemulangan } \\
\text { WNI } \\
\text { bermasalah }\end{array}$ & 1 & 1 & 0 & 0 & 2 \\
\hline 8 & $\begin{array}{l}\text { Permohonan } \\
\text { bantuan hukum }\end{array}$ & 1 & 0 & 0 & 0 & 1 \\
\hline 9 & $\begin{array}{l}\text { Gaji belum } \\
\text { dibayarkan }\end{array}$ & 1 & 0 & 0 & 0 & 1 \\
\hline
\end{tabular}




\begin{tabular}{|c|c|c|c|c|c|}
\hline Total & 33 & 18 & 29 & 14 & 64 \\
\hline $\begin{array}{c}\text { Total Kasus } \\
\text { Keseluruhan }\end{array}$ & 44 & 25 & 44 & 33 & 146 \\
\hline
\end{tabular}

Sumber: Diolah dari data BP3TKI Makassar

Data di atas menunjukkan klaim asuransi menjadi kasus yang paling besar dialami oleh pekerja migran asal Sulsel di Malaysia. Disusul kasus pemulangan jenazah dan pemulangan TKI B (overstay). Total kasus yang dialami oleh pekerja migran asal Sulsel di Malaysia sebanyak 64 kasus dari 146 kasus secara keseluruhan. Menanggapi besarnya jumlah kasus klaim asuransi. Kartini Baharuddin, Kepala Kantor Pelayanan Konsorsium ASTINDO Sulawesi Selatan menjelaskan:

"Perusahaan yang melayani klaim asuransi TKI ada tiga secara nasional yakni ASTINDO, JASINDO dan Mitra. Untuk wilayah Sulawesi Selatan ada dua yakni ASTINDO dan Jasindo. Salah satu kasus yang pernah kami tangani adalah Nurbaya Lampe, TKI asal Bulukumba yang diberangkatkan dari Pare-Pare. Laporannya diterima BP3TKI Makassar pada 21 April 2014 dan kami bayarkan pada 13 Mei 2014 sebesar 80 juta. Penyelesaian klaim diusahakan dalam 14 hari kerja dengan syarat bahwa dokumen lengkap, proses klaim yang lama dikarenakan dokumen tidak lengkap."

Pernyataan di atas menguraikan proses klaim asuransi melalui konsorsium ASTINDO. Contoh kasus yang pernah ditangani oleh ASTINDO yakni Nurbaya Lampe, TKI asal Bulukumba. Penyelesaian klaim asuransi oleh TKI tersebut jika dihitung sejak laporan diterima BP3TKI Makassar pada 21 April 2014 hingga tanggal penyerahan 13 Mei 2014 maka waktu tunggu yang dibutuhkan selama 21 hari. Komitmen konsorsium ASTINDO yakni menyelesaikan klaim dalam 14 hari kerja. Perbedaan waktu tunggu dengan komitmen penyelesaian klaim bisa disebabkan berbagai faktor, salah satunya kelengkapan dokumen. 
Pemerintah Malaysia juga memberikan pengawasan terhadap pekerja maupun majikan melalui penegakan hukum ketenagakerjaan Sabah. Jabatan Tenaga Kerja Sabah melalui situs web resminya merilis:

"Penguatkuasaan undang-undang buruh/penegakan hukum ketenagakerjaan dijalankan sebagai berikut: (1) melakukan inspeksi ke tempat-tempat kerja untuk memastikan ketentuan hukum perburuhan dipatuhi oleh majikan dan pekerja; (2) menyelidiki dan menyelesaikan keluhan pekerja dan klaim kompensasi pekerja; (3) mengatur pekerja non-penduduk melalui penerbitan Izin untuk Memperkerjakan Karyawan Non-resident (License to Employ NonResident Employees); (4) melakukan operasi penegakan khusus dengan departemen terkait lainnya/instansi di tempat kerja dimana pekerja non-penduduk diduga dipekerjakan; (5) menuntut majikan yang telah melanggar ketentuan hukum perburuhan; (6) mengatur pekerjaan bagi anak-anak, pemuda dan perempuan; dan (7) menangani pertanyaan dan banding dari majikan, pekerja, serikat pekerja dan masyarakat mengenai masalah ketenagakerjaan." 44

Rilis di atas mengungkapkan bahwa JTK Sabah melakukan inspeksi ke tempat kerja, menangani kompensasi bagi pekerja, menerbitkan izin bagi pekerja non-penduduk, melakukan operasi bagi pekerja ilegal, menuntut majikan jika ada pelanggaran atau aduan dari pekerja, menerapkan aturan bagi pekerja anak, pemuda dan perempuan dan memberikan pelayanan atas pertanyaan maupun tuntutan hukum dari majikan, pekerja maupun masyarakat mengenai masalah ketenagakerjaan.

Pelayanan JTK Sabah tertuang dalam piagam pelanggan yang menjelaskan bahwa JTK Sabah bertanggungjawab terhadap pemenuhan dan pengaturan antara kepentingan majikan dan pekerja disamping itu juga menciptakan hubungan yang harmonis diantara keduanya dan serikat pekerja. Hal ini dilaksanakan berdasarkan janji dan komitmen,

\footnotetext{
${ }^{44}$ Jabatan Tenaga Kerja Sabah, n.d., Fungsi -

http://jtksbh.mohr.gov.my/index.php/en/about-us/functions, diakses 11 Juli 2016.
} 
sebagai berikut: (1) pengendalian kes aduan buruh (Handling of Labour Complaint Case): menyelidiki dan menyelesaikan setiap pengaduan pekerja dalam tempo 3 minggu dari tanggal pengaduan diterima, kecuali kasus yang sulit; (2) pengendalian kes tuntutan (Handling of Labour Claim Case): menyelidiki dan menyelesaikan setiap klaim dalam tempo satu setengah bulan dari tanggal kasus klaim diterima, kecuali kasus yang sulit atau informasi tidak lengkap.

Selanjutnya, (3) pengendalian kes pampasan kerja (Handling of Workmen's Compensation Claim Cases): (a) Kasus Ketidakmampuan Sementara: menyelidiki dan menyelesaikan setiap kasus dalam tempo 2 minggu dari tanggal pemberitahuan klaim kecelakaan diterima, kecuali kasus yang sulit atau informasi tidak lengkap; (b) Kasus Ketidakmampuan Tetap dan Fatal: menyelidiki dan menyelesaikan setiap kasus dalam 1 bulan dari tanggal pemberitahuan klaim kecelakaan diterima, keculai bagi kasus yang rumit atau informasi tidak lengkap; (4) pengendalian Permohonan Lesen untuk Menggaji Pekerja bukan Pemastautin (Handling of Application For Licenses To Employ Non-Resident Employee): memproses dan mengeluarkan lisensi untuk menggaji/mempekerjakan pekerja bukan penduduk dalam tempo 2 minggu selepas menerima permohonan lengkap dari majikan ${ }^{45}$.

Kemudian, (5) pengendalian pendakwaan: menyediakan dokumen hasil penyelidikan untuk tujuan pendakwaan dalam tempo waktu 1 bulan, kecuali bagi kasus yang sulit atau informasi tidak lengkap;

\footnotetext{
45 Jabatan Tenaga Kerja Sabah, n.d., Piagam Pelanggan -

http://jtksbh.mohr.gov.my/index.php/en/about-us/client-charter, diakses 11 Juli 2016.
} 
pengendalian permohonan permit: memproses permohonan permit (izin) dalam tempo waktu 1 bulan dan mengeluarkan izin di peringkat Ibu pejabat dalam tempo waktu 2 minggu berdasarkan permohonan yang lengkap; (7) permohonan lessen agensi pekerjaan swasta: memproses permohonan untuk mendapatkan lessen agensi pekerjaan swasta dalam tempo satu bulan dari permohonan lengkap diterima; dan (8) khidmat nasihat (saran): memberi khidmat nasihat kepada setiap pelanggan dengan segera, tepat, mesra dan prihatin. ${ }^{46}$

Berdasarkan pemaparan di atas maka dapat dipahami bahwa swasta dalam hal ini majikan/pengguna TKI di negara penempatan mendapatkan pengawasan dari pemerintah Indonesia melalui perwakilannya dan juga dari pemerintah Malaysia melalui Jabatan Tenaga Kerja Sabah. Pemerintah kedua negara tentu berupaya untuk menegakkan hukumnya masing-masing. Sebagaimana Konsulat RI Tawau dalam melaksanakan fungsi perlindungannya mengacu pada Undang-Undang dan menghormati Undang-Undang di negara penempatan, sedangkan Jabatan Tenaga Kerja Sabah yang berperan menegakkan hukum yang berlaku di Sabah Malaysia. Persamaan kedua lembaga tersebut dalam berinteraksi dengan majikan/perusahaan yakni menjadi jembatan bagi pekerja untuk menyelesaikan permasalahannya.

Walaupun pemerintah Malaysia turut memberikan pengawasan terhadap TKI di negara penempatan. Namun demikian, informan

${ }^{46}$ Jabatan Tenaga Kerja Sabah, n.d., loc. cit. 
mengakui bahwa masih ada ketakutan TKI terhadap aparat penegak hukum Malaysia. Berikut tanggapan yang diberikan:

Arief Cahyo Setyawan (29 tahun) yang telah kembali dari Malaysia menceritakan pengalamannya saat menjadi TKI:

"Saya sering melihat sendiri, TKI kita sembunyi di got kalau melihat polisi Malaysia atau lari ke hutan hanya untuk menghindari polisi, padahal mereka bukan TKI ilegal. Hal ini terjadi karena rendahnya pengetahuan hukum, sehingga tidak berani dan tidak bisa menjelaskan kepada polisi Malaysia. Saya pernah ditangkap polisi, tapi akhirnya bisa saya jelaskan, kalau saya TKI legal dan akhirnya dilepaskan".

Informasi dari Arief mengungkap bahwa aparat penegak hukum Malaysia menjadi sosok yang menakutkan bagi TKI, termasuk TKI legal. Hal ini terjadi disebabkan beberapa kemungkinan, salah satunya yang diungkap informan bahwa TKI memiliki pengetahuan hukum yang rendah, sehingga tidak berani dan tidak bisa menjelaskan. Kemungkinan lainnya kondisi saat bertemu aparat penegak hukum Malaysia, TKI tersebut tidak memiliki identitas apapun, sehingga ia memilih untuk menghindar.daripada mengambil resiko ditahan.

Perlakuan ini juga dialami Asma asal Pare-Pare yang pernah mengalaminya saat menjadi TKI.

"Saya dan teman-teman yang bekerja di ladang kalau ada polisi lari bersembunyi. Karena memang kami tidak punya surat-surat waktu itu. Polisi Malaysia kalau sedang penggerebekan dinaikkan semua, setelah itu baru dilihat mana lengkap suratnya dibebaskan, sedangkan yang tidak lengkap suratnya ditahan."

Informasi dari Asma mengungkap kasus yang sama dengan Arief. Perbedaannya terletak pada status mereka, Arief merupakan TKI legal/prosedural, sedangkan Asma adalah TKI ilegal/non-prosedural 
sehingga tingkat keberanian untuk memberikan penjelasan kepada aparat penegak hukum Malaysia berbeda.

Pemaparan di atas merupakan realita yang dihadapi oleh TKI di Sabah Malaysia, termasuk TKI asal Sulsel. Pengalaman Arief Cahyo yang pernah bekerja di Malaysia memperlihatkan kasus bahwa TKI masih dibayangi ketakutan ketika berhadapan dengan aparat penegak hukum di Malaysia. Hal tersebut juga dialami Asma yang merasa ketakutan ketika sedang terjadi penggerebekan (razia) di ladang tempatnya bekerja. Ditambah lagi dengan dokumen yang tidak lengkap, sehingga dirinya merasa terancam.

\subsubsection{Peran Masyarakat Sipil}

Peran masyarakat sipil di negara penempatan Malaysia memiliki karakteristik yang berbeda. Hasil kajian dari Muhammad Irsyadul Ibad, Koordinator Pusat Sumber Daya Buruh Migran (PSDBM) menyatakan:

"Kondisi organisasi dan kelompok Buruh Migran Indonesia (BMI) di Malaysia memiliki sedikit perbedaan, dengan organisasi dan kelompok BMI di negara penempatan lain seperti Hong Kong, Taiwan, dan Singapura. BMI di Malaysia, tidak bisa dengan leluasa mengikuti atau membuat suatu organisasi. Nihilnya keberadaan organisasi perburuhan pekerja migran Indonesia di Malaysia terkait erat dengan kondisi politik. Pemerintah Malaysia tidak membolehkan kelompok pekerja migran untuk mendirikan serikat buruh. Namun demikian, Pemerintah Malaysia masih mengizinkan pekerja migran untuk bergabung dengan serikat buruh yang ada di Malaysia" 47

Izin yang diberikan oleh Pemerintah Malaysia, sayangnya tidak disambut baik oleh serikat buruh di Malaysia. Hal ini dikarenakan, pekerja migran dinilai sebagai ancaman bagi pekerja asal Malaysia. Maria

\footnotetext{
${ }^{47}$ Buruhmigran.or.id, 2014, Mengenal Kondisi Organisasi dan Kelompok Buruh Migran di Malaysia - http://pantaupjtki.buruhmigran.or.id/index.php/read/mengenal-kondisiorganisasi-dan-kelompok-buruh-migran-di-malaysia, diakses 19 Juli 2016.
} 
Christine, anggota dewan di ASEAN Services Employees Trade Union Council (ASETUC) mengungkapkan:

"Tidak bolehnya pekerja migran masuk dalam serikat buruh di Malaysia, menyebabkan aspirasi pekerja migran menjadi sulit disampaikan pada pemerintah setempat. Lebih parahnya lagi, agenda dan aspirasi penting pekerja migran di Malaysia juga tidak turut menjadi agenda penting yang disampaikan oleh serikat buruh Malaysia"48

Oganisasi BMI di Malaysia, masih berdasarkan atas beberapa identitas seperti organisasi keagamaan, paguyuban daerah dan kesenian. Aktivitas BMI umumnya terfokus pada lingkup sosial, seperti pengurusan jenazah/kematian warga Indonesia; bidang agama seperti penyelenggaraan pengajian dan misa bersama; serta kegiatan pemberdayaan anggota komunitas, seperti pelatihan ketrampilan tertentu. Komunitas tersebut sayangnya belum dibersamai dengan kegiatan penyediaan informasi tentang ketenagakerjaan maupun soal proses migrasi. Padahal, kegiatan pemenuhan informasi tersebut sangat penting bagi BMI. Muhammad Irsyadul Ibad, Koordinator PSDBM menjelaskan:

"Buruh Migran Indonesia (BMI) di Malaysia sering kebingungan mencari tempat bertanya dan memperoleh informasi spesifik tentang proses pengurusan dokumen dan penanganan kasus. Hal inilah yang menunjukkan betapa penting keberadaan komunitas untuk menunjang informasi-informasi yang dibutuhkan oleh BMl"49

Pernyataan yang dipaparkan di atas menjelaskan karakteristik serikat pekerja di Malaysia. Pemerintah Malaysia tidak membolehkan dibentuknya serikat pekerja migran sebagaimana dilakukan di beberapa negara penempatan dengan jumlah TKI yang signifikan. Walaupun pekerja migran dibolehkan untuk bergabung dengan serikat buruh yang

\footnotetext{
${ }^{48}$ Ibid.

${ }^{49}$ Ibid.
} 
ada di Malaysia, namun kendala yang dihadapi yakni pekerja asal Malaysia memberikan penolakan. Hal ini mengakibatkan aspirasi pekerja migran di Malaysia tidak mendapatkan perhatian pemerintah. Komunitas yang terbentuk dari pekerja migran Indonesia di Malaysia saat ini justru organisasi keagamaan, paguyuban daerah dan kesenian. Sedangkan yang diharapkan yakni terbentuknya komunitas yang saling mengedukasi mengenai hak-haknya sebagai pekerja migran.

Realita bagi pekerja migran asal Sulawesi Selatan di Malaysia tidak terlalu bersinggungan dengan problematika di atas. Lingkungan kerja yang berkelompok dengan jumlah yang cukup besar di tiap ladang memberikan keuntungan bagi TKI/PMI asal Sulsel untuk menyampaikan keluhannya langsung kepada majikan. Di samping itu, Konsulat RI Tawau juga cukup aktif melakukan kunjungan lapangan untuk meninjau TKI di ladang, serta Jabatan Tenaga Kerja Sabah yang turut mengawasi perlakuan majikan kepada pekerjanya. Sehingga atmosfir peran masyarakat sipil dalam masa penempatan cukup kondusif bagi pekerja migran asal Sulsel.

Berdasarkan pemaparan pada tiga bagian di atas, maka secara sederhana pemenuhan hak-hak pekerja migran asal Sulawesi Selatan pada masa penempatan dapat dilihat dari tabel berikut:

Tabel 5.17 Pemenuhan Hak-Hak Pekerja Migran asal Sulsel pada Masa Pra-Penempatan

\begin{tabular}{|l|l|l|}
\hline No. & Analisis Ekonomi Politik & \multicolumn{1}{c|}{ Tinjauan } \\
\hline 1 & Peran Pemerintah & $\begin{array}{l}\text { - Pemerintah pada masa penempatan } \\
\text { berperan melalui perwakilan RI } \\
\text { - Sikap perwakilan RI mengacu pada }\end{array}$ \\
\hline
\end{tabular}




\begin{tabular}{|c|c|c|}
\hline & & $\begin{array}{l}\text { sikap Kementerian Luar Negeri RI } \\
\text { - KRI Tawau memiliki prioritas untuk } \\
\text { memberikan pelayanan dan } \\
\text { perlindungan bagi TKI } \\
\text { - Pemerintah melakukan deportasi } \\
\text { dalam rangka perlindungan TKI } \\
\text { - WNI/TKI yang dideportasi selama } \\
\text { 2012-2015 mayoritas berasal dari } \\
\text { Sulawesi Selatan } \\
\text { - Pemerintah provinsi Sulawesi Selatan } \\
\text { diharapkan berperan untuk mencari } \\
\text { solusi bagi TKI asal Sulsel } \\
\text { - Pemerintah Malaysia melalui Jabatan } \\
\text { Tenaga Kerja Sabah mengawasi } \\
\text { pekerja asing, termasuk TKI } \\
\text { - Pemerintah Malaysia memiliki } \\
\text { mekanisme untuk melindungi pasar } \\
\text { tenaga kerja lokal, sehingga lapangan } \\
\text { kerja dengan kategori 3D (dirty, } \\
\text { dangerous, difficult) yang tidak diminati } \\
\text { pekerja lokal dibuka untuk pekerja asing } \\
\text { - JTK Sabah mengacu pada Sabah } \\
\text { Labour Ordinance (Ordinan Buruh } \\
\text { Sabah) dalam penegakan aturan bagi } \\
\text { pekerja lokal dan pekerja asing di } \\
\text { Sabah }\end{array}$ \\
\hline 2 & $\begin{array}{l}\text { Interaksi Pemerintah dan } \\
\text { Swasta }\end{array}$ & $\begin{array}{l}\text { - Majikan/pengguna yang } \\
\text { mempekerjakan TKI asal Sulsel tidak } \\
\text { hanya swasta, tetapi juga perusahaan } \\
\text { milik pemerintah } \\
\text { - KRI Tawau mendata pekerja } \\
\text { perkebunan di wilayah Tawau dan } \\
\text { melakukan kunjungan ke ladang } \\
\text { - KRI Tawau menerima pengaduan } \\
\text { melalui telepon, faks, SMS, email, } \\
\text { maupun datang ke kantor, apabila ada } \\
\text { permasalahan dengan majikan } \\
\text { - KRI Tawau memiliki Satgas } \\
\text { Perlindungan WNI/TKI untuk melayani } \\
\text { permasalahan TKI } \\
\text { - KRI Tawau juga memberikan } \\
\text { pelayanan pengembalian tuntutan gaji } \\
\text { WNI/TKI } \\
\text { - Kasus TKI asal Sulsel pada masa } \\
\text { penempatan yang terdata BP3TKI } \\
\text { Makassar dengan jumlah terbesar } \\
\text { selama 2012-2015 yakni klaim asuransi } \\
\text { - BP3TKI Makassar di daerah asal }\end{array}$ \\
\hline
\end{tabular}




\begin{tabular}{|c|c|c|}
\hline & & $\begin{array}{l}\text { menangani kasus yang } \\
\text { penyelesaiannya berada di daerah asal } \\
\text { seperti asuransi sedangkian } \\
\text { pemenuhan hak-hak pada masa } \\
\text { penempatan sudah diselesaikan oleh } \\
\text { KRI Tawau } \\
\text { - Pemerintah Malaysia ikut memberikan } \\
\text { pengawasan kepada pekerja maupun } \\
\text { majikan melalui JTK Sabah dengan } \\
\text { melakukan inspeksi ke lapangan } \\
\text { maupun menerima aduan di kantor } \\
\text { - Piagam pelanggan JTK Sabah } \\
\text { mengatur kepentingan majikan dan } \\
\text { pekerja dan menciptakan hubungan } \\
\text { yang harmonis }\end{array}$ \\
\hline 3 & Peran Masyarakat Sipil & $\begin{array}{l}\text { - Serikat pekerja migran tidak diizinkan } \\
\text { di Malaysia } \\
\text { - Pekerja migran dianggap ancaman } \\
\text { bagi pekerja asal Malaysia } \\
\text { - Organisasi TKI di Malaysia masih } \\
\text { terbatas dengan kegiatan keagamaan, } \\
\text { paguyuban daerah dan kesenian } \\
\text { - Kegiatan penyediaan informasi } \\
\text { ketenagakerjaan maupun proses } \\
\text { migrasi belum diwadahi } \\
\text { - Pekerja migran asal Sulsel di Sabah } \\
\text { Malaysia memiliki mekanisme tersendiri } \\
\text { untuk menyelesaikan masalah dengan } \\
\text { majikan dikarenakan lingkungan kerja } \\
\text { yang berkelompok dengan jumlah yang } \\
\text { cukup besar }\end{array}$ \\
\hline
\end{tabular}

Sumber: Diolah oleh Peneliti

Berdasarkan pemaparan di atas peran hukum dalam ekonomi politik kelembagaan yang dikemukakan oleh Commons, Coase dan North sebagaimana yang telah diidentifikasi pada masa pra-penempatan jgua terlihat pada masa penempatan. Masing-masing aktor menerapkan aturan main, seperti Konsulat RI Tawau yang menjalankan fungsi kelembagaannya sebagai perwakilan pemerintah Indonesia di negara penempatan yang menjalankan kebijakan/hukum berdasarkan arahan dari Kementerian Luar Negeri RI. Demikian juga dengan pemerintah Malaysia 
yang telah menerapkan mekanisme tapisan sejak masa pra-penempatan, semakin mendominasi aturan main dikarenakan pekerja migran Indonesia berada dalam wilayah kekuasaan hukumnya, sehingga pekerja migran Indonesia yang dikategorikan pekerja asing di Malaysia wajib mematuhi aturan di Sabah Malaysia dengan mengacu pada aturan pokok Sabah Labour Ordinance (Ordinan Buruh Sabah).

Fakta di atas semakin menegaskan asumsi peneliti terkait kuatnya hubungan antara peran hukum/kebijakan dalam ekonomi politik kelembagaan dengan pemenuhan hak-hak pekerja migran asal Sulawesi Selatan. Seyogyanya aturan main dalam ekonomi politik kelembagaan memberikan rasa aman dan nyaman, sehingga tujuan ekonomi yang menjadi luaran dari proses migrasi pekerja dapat tercapai dan kelembagaan yang terlibat dalam proses tersebut juga dapat memperoleh manfaat.

Pernyataan jika pelaku ekonomi (TKI) dari aturan main yang telah ditetapkan melakukan pelanggaran/penyimpangan, maka akan menghadapi resiko. Pernyataan teoretis ini ditanggapi pada penjelasan di atas bahwa hadirnya kebijakan/hukum tersebut merupakan respon atas terjadinya kasus yang berkaitan dengan TKI/PMI yang berkembang ke arah perdagangan orang (trafficking), dikarenakan sebelum hadirnya kebijakan tersebut penempatan TKI hanya mengacu pada Ordonansi tentang Pengerahan Orang Indonesia Untuk Melakukan Pekerjaan di Luar Indonesia (Staatsblad Tahun 1887 Nomor 8) dan Keputusan Menteri serta 
peraturan pelaksanaannya yang masih sangat sederhana dan belum komprehensif.

Hal ini sejalan dengan semangat yang dinyatakan dalam penjelasan UU No. 39 Tahun 2004 yang menyatakan pada hakekatnya ketentuan ketentuan hukum yang dibutuhkan dalam masalah ini adalah ketentuan-ketentuan yang mampu mengatur pemberian pelayanan penempatan bagi tenaga kerja secara baik. Pemberian pelayanan penempatan secara baik didalamnya mengandung prinsip murah, cepat, tidak berbelit belit dan aman. Pengaturan yang bertentangan dengan prinsip tersebut memicu terjadinya penempatan tenaga kerja ilegal yang tentunya berdampak kepada minimnya perlindungan bagi tenaga kerja yang bersangkutan. Sejalan dengan semakin meningkatnya tenaga kerja yang ingin bekerja di luar negeri dan besarnya jumlah TKI yang sekarang ini bekerja di luar negeri, meningkat pula kasus perlakuan yang tidak manusiawi terhadap TKI baik di dalam maupun di luar negeri. Kasus yang berkaitan dengan nasib TKI semakin beragam dan bahkan berkembang ke arah perdagangan manusia yang dapat dikategorikan sebagai kejahatan terhadap kemanusiaan.

Pekerja migran asal Sulawesi Selatan yang mematuhi aturan main sejak masa pra-penempatan dapat bekerja dengan tenang dan aman di masa penempatan hingga kontrak kerja berakhir. Sehingga tujuan untuk memaksimalkan keuntungan ekonomi dari proses migrasi dapat tercapai. Sedangkan bagi TKI/PMI yang menempuh jalur non-prosedural mendapatkan akses yang minim terhadap lembaga-lembaga yang dapat 
menjamin pemenuhan hak-haknya seperti perwakilan RI maupun jabatan tenaga kerja. Akibatnya tanpa kehadiran institusi yang melindungi hakhaknya, biaya transaksi menjadi tinggi. Selain itu, TKI/PMI non-prosedural menghadapi resiko penipuan, pemerasan, ancaman fisik dan bentukbentuk ketidaksiapan lainnya. Hal tersebut terjadi pada TKI/WNI yang dideportasi setiap bulannya kembali ke Indonesia.

Model interaksi yang terbentuk dari analisis ekonomi politik dalam pemenuhan hak-hak pekerja migran asal Sulawesi Selatan pada masa penempatan berdasarkan identifikasi Bustanul Arifin dalam Deliarnov yakni model invisible hand. Ditinjau dari sisi sistem hukum, pemerintah Indonesia melalui perwakilannya maupun pemerintah Malaysia menyediakan sarana dan prasarana dasar seperti seperangkat pelayanan untuk perlindungan TKI. Pemerintah Indonesia menggunakan perangkat hukum setempat untuk menuntut hak-hak TKI yang tidak dipenuhi. Sedangkan pemerintah Malaysia menggunakan aturannya untuk mengawasi pekerja maupun majikan sehingga keduanya wajib mematuhi aturan tersebut. Sedangkan tinjauan peraturan/regulasi, pemerintah mengeluarkan peraturan dan ikut mematuhi peraturan. Pemerintah Indonesia menghormati peraturan pemerintah Malaysia dan perusahaan Malaysia yang ingin mendapatkan jaminan terhadap TKI yang dipekerjakan juga menempuh aturan yang ditetapkan oleh pemerintah Indonesia saat pra-penempatan. Kebutuhan dunia usaha terhadap TKI yang cukup tinggi atas pekerja sektor perkebunan membuka akses bagi TKI untuk ditempatkan pada sektor pekerjaan tersebut. 


\section{BAB VI}

\section{PENUTUP}

Bab ini membahas dua bagian yakni kesimpulan dan saran dari penelitian tesis Analisis Ekonomi Politik Pemenuhan Hak-Hak Pekerja Migran asal Sulawesi Selatan di Malaysia. Penarikan kesimpulan berdasarkan rumusan masalah dari penelitian yakni pemenuhan hak-hak pekerja migran pada masa pra-penempatan dan masa penempatan. Sedangkan saran-saran merupakan masukan yang didapatkan dari proses penelitian yang diharapkan dapat menjadikan penempatan TKI asal Sulawesi Selatan menjadi lebih baik.

\subsection{Kesimpulan}

1. Pemenuhan hak-hak pekerja migran asal Sulawesi Selatan pada masa pra-penempatan berdasarkan UU No. 39 Tahun 2004 bersesuaian dengan pendekatan peran hukum dalam ekonomi politik kelembagaan. Hal ini terlihat dari seperangkat aturan yang merupakan turunan dari UU No. 39 Tahun 2004 ditetapkan oleh pemerintah sebagai aturan main bagi swasta (PPTKIS) untuk menempatkan TKI. Pemerintah Malaysia juga telah terlibat dalam menerapkan standar tertentu bagi pekerja migran asal Sulawesi Selatan melalui mekanisme "tapisan" untuk memastikan bahwa TKI tidak mempunyai masalah dengan majikan dan bersih dari pelanggaran di Imigrasi Malaysia. Keuntungan politik bagi pemerintah Indonesia jika kebijakan penempatan TKI ini dipatuhi oleh swasta dan juga masyarakat (CTKI) akan menunjukkan wibawa pemerintah terhadap negara penempatan. Sedangkan 
keuntungan ekonomi juga diperoleh oleh TKI yakni dapat mengoptimalkan pendapatan (gaji) yang diperoleh dari hasil bekerja. Pemerintah juga mendapatkan keuntungan ekonomi dari TKI melalui devisa yang dihasilkan dari remitansi (kiriman uang) kepada pemerintah pusat, sedangkan bagi pemerintah daerah kiriman uang yang diterima oleh keluarga TKI berkontribusi terhadap pembangunan di daerah TKI, yakni Sulawesi Selatan. Keuntungan ekonomi dan politik ini dapat terwujud apabila TKI mengikuti prosedur yang telah ditetapkan oleh pemerintah.

2. Pemenuhan hak-hak pekerja migran asal Sulawesi Selatan pada masa penempatan berdasarkan UU No. 39 Tahun 2004 juga menunjukkan pendekatan yang sama dengan masa pra-penempatan yakni peran hukum dalam ekonomi politik kelembagaan. Perwakilan pemerintah Indonesia di Tawau menjalankan kebijakan/hukum berdasarkan arahan dari Kementerian Luar Negeri RI yang bersumber dari UU No. 37 Tahun 1999 terkait pelaksanaan hubungan luar negeri dan UU No. 39 Tahun 2004 terkait perlindungan TKI di masa penempatan kemudian diturunkan lagi dalam PP No. 3 Tahun 2013 yang mengatur lebih detil perlindungan yang diberikan. Pemerintah Malaysia sebagai negara penempatan juga menjalankan aturan mainnya dengan menerapkan kebijakan Sabah Labour Ordinance (Ordinan Buruh Sabah). Keuntungan politik pada masa penempatan tentunya diperoleh oleh kedua pihak yakni pemerintah Indonesia dan pemerintah Malaysia. Pemerintah Indonesia memberikan kesempatan 
kerja kepada warga negaranya di Malaysia, sedangkan Malaysia mempekerjakan tenaga kerja untuk mendorong pembangunan negaranya. Keuntungan ekonomi bagi pemerintah Indonesia terwujud melalui gaji yang diterima oleh TKI dan dikirimkan ke daerah asal yang membantu pemerintah pusat melalui devisa dari remitansi TKI dan juga penguatan ekonomi keluarga TKI di daerah asal yang menguntungkan pemerintah daerah dalam rangka pemerataan pembangunan dan peningkatan taraf hidup masyarakat.

\subsection{Saran}

1. Pemerintah provinsi Sulawesi Selatan seyogyanya meningkatkan kualitas sumber daya manusia (SDM) dan keterampilan TKI yang dikirimkan agar mampu bersaing dengan tenaga kerja terampil, selain sektor perkebunan.

2. Pemerintah provinsi Sulawesi Selatan seyogyanya memantau kondisi TKI di Sabah Malaysia dengan melakukan kunjungan langsung ke ladang atau memperbaharui informasi melalui perwakilan RI untuk memastikan bahwa hak-hak TKI selama masa penempatan dipenuhi oleh majikan/pengguna. 


\section{DAFTAR PUSTAKA}

\section{Buku}

Agusmidah. (2011). Dilematika Hukum Ketenagakerjaan: Tinjauan Politik Hukum. Medan: PT. Sofmedia.

Agustino, Leo. (2012). Dasar-Dasar Kebijakan Publik. Bandung: Penerbit Alfabeta Bandung.

Ali, Faried dan Andi Syamsu Alam. (2012). Studi Kebijakan Pemerintah. Bandung: Refika Aditama.

Ali, Faried, Andi Syamsu Alam, dan Sastro M. Wantu. (2012). Studi Analisa Kebijakan: Konsep, Teori dan Aplikasi Sampel Teknik Analisa Kebijakan Pemerintah. Bandung: Refika Aditama.

Asyhadie, Zaeni. (2007). Hukum Kerja: Hukum Ketenagakerjaan Bidang Hubungan Kerja. Jakarta: PT. RajaGrafindo Persada.

Budiardjo, Miriam. (2010). Dasar-Dasar Ilmu Politik: Edisi Revisi. Jakarta: Gramedia Pustaka Utama.

Caporaso, James A. dan David P. Levine. (2008). Teori-Teori Ekonomi Politik. Yogyakarta: Pustaka Pelajar.

Chuan, Goh Chen. (2013). Guide to the Employment Act and Labour Laws of Malaysia. Selangor: Leeds Publications.

Daniel, Moehar. (2002). Metode Penelitian Sosial Ekonomi. Jakarta: Bumi Aksara.

Deliarnov. (2006). Ekonomi Politik. Jakarta: Penerbit Erlangga.

Efriza. (2012). Political Explore: Sebuah Kajian Ilmu Politik. Bandung: Penerbit Alfabeta.

Fischer, Frank, Gerald J. Miller dan Mara S. Sidney. (2015). Handbook Analisis Kebijakan Publik (terj.). Bandung: Penerbit Nusa Media.

Husni, Lalu. (2012). Pengantar Hukum Ketenagakerjaan Indonesia. Jakarta: Rajawali Pers.

Indiahono, Dwiyanto. (2009). Kebijakan Publik Berbasis Dynamic Policy Analysis. Yogyakarta: Penerbit Gava Media.

Iskandar, Pranoto (ed.). (2011). Standar Internasional Migrasi Ketenagakerjaan Berbasis HAM. Cianjur: IMR Press 
Iskandar, Pranoto. (2013). Hukum HAM Internasional: Suatu Pengantar Kontekstual. Cianjur, IMR Press.

Keliat, Makmur dkk. (2012). Ekonomi Politik Independensi Bank Indonesia: Studi Kasus Bank Century. Jakarta: UI Press.

Kusumanegara, Solahuddin. (2010). Model dan Aktor dalam Proses Kebijakan Publik. Yogyakarta, Gava Media.

Muhtaj, Majda El. (2013). Dimensi-Dimensi HAM: Mengurai Hak Ekonomi, Sosial dan Budaya. Jakarta: Rajawali Pers.

Nugroho, Riant. (2012). Public Policy. Jakarta: PT. Elex Media Komputindo.

Nugroho, Riant. (2014). Metode Penelitian Kebijakan. Yogyakarta: Pustaka Pelajar.

Nugroho, Riant. (2014). Kebijakan Publik di Negara-negara Berkembang. Yogyakarta: Pustaka Pelajar.

Purwanto, Erwan Agus dan Dyah Ratih Sulistyastuti. (2012). Implementasi Kebijakan Publik: Konsep dan Aplikasinya di Indonesia. Yogyakarta: Penerbit Gava Media.

Rachbini, Didik J. (2001). Analisis Kritis Ekonomi Politik Indonesia. Yogyakarta: Pustaka Pelajar.

Rakasima, Mahmud F. dkk. (2012). Seratus TKI Sukses. Jakarta: BNP2TKI.

Silalahi, Ulber. (2012). Metode Penelitian Sosial. Bandung: PT. Refika Aditama.

Suharto, Edi. (2012). Analisis Kebijakan Publik: Panduan Praktis Mengkaji Masalah dan Kebijakan Sosial. Bandung: Penerbit Alfabeta.

Wibawa, Samodra. (2011). Politik Perumusan Kebijakan Publik. Yogyakarta: Graha Ilmu.

Yin, Robert K. (2003). Studi Kasus Desain dan Metode. Jakarta: Raja Grafindo Persada.

Yustika, Ahmad Erani. (2009). Ekonomi Politik: Kajian Teoretis dan Analisis Empiris. Yogyakarta: Pustaka Pelajar. 
Yuwono, Ismantoro Dwi. (2011). Hak dan Kewajiban Tenaga Kerja Indonesia di Luar Negeri. Yogyakarta: Penerbit Pustaka Yustisia.

\section{Dokumen/Laporan/Wawancara}

\section{Hukum Nasional}

Undang-Undang No. 39 Tahun 2004 tentang Penempatan dan Perlindungan Tenaga Kerja Indonesia di Luar Negeri

Peraturan Pemerintah No. 3 Tahun 2013 tentang Perlindungan Tenaga Kerja Indonesia di Luar Negeri

Jabatan Tenaga Kerja Sabah. (n.d.) Labour Ordinance (Sabah Cap. 67): Amanded as at 10.02.2005 by Act A.1238. Sabah: Kelab Kebajikan dan Sosial (KESERU).

Kaedah-Kaedah Buruh (Sabah) Kandungan Kontrak 2008

\section{Lembaga Pemerintah}

Bank Indonesia. (2009). Laporan Survei Nasional Pola Remitansi TKI Tahun 2008. Jakarta: Bank Indonesia.

BNP2TKI. (2012). Peraturan Kepala Badan Nasional Penempatan dan Perlindungan Tenaga Kerja Indonesia Nomor Per. 13/KA/VII/2012 tentang Standar Pelayanan Perlindungan Tenaga Kerja Indonesia. Jakarta: Deputi Bidang Perlindungan BNP2TKI.

BNP2TKI. (2015). BI Mencatat Remitansi TKI Tahun 2014 sebesar Rp. 105,9 Trilyun - http://www.bnp2tki.go.id/read/9887/BI-Mencatat-RemitansiTKI-Tahun-2014-Sebesar-Rp-1059-Trilyun, diakses 24 November 2015.

BNP2TKI. (2016). Daftar PPTKIS Provinsi Sulawesi Selatan 2016 http://www.bnp2tki.go.id/read/11027/Daftar-PPTKIS-Provinsi-SulawesiSelatan-2016.html, diakses 12 Juli 2016.

BP3TKI Makassar. (2013). Laporan Penerimaan Remitansi TKI BP3TKI Makassar Tahun 2013. Makassar: BP3TKI Makassar.

BP3TKI Makassar. (2014). Laporan Penerimaan Remitansi TKI BP3TKI Makassar Tahun 2014. Makassar: BP3TKI Makassar.

BP3TKI Makassar. (2015). Data Permasalahan TKI ke Luar Negeri BP3TKI Makassar, 2012, 2013, 2014 dan 2015. Makassar: BP3TKI Makassar. 
Direktorat Jenderal Binapenta dan PKK Kemenaker RI. n.d. Direktorat Penempatan dan Perlindungan Tenaga Kerja Luar Negeri (PPTKLN) http://binapenta.naker.go.id/page/direktorat-pptkln, diakses 11 Juli 2016.

Jabatan Tenaga Kerja Sabah. (n.d.) Brosur Sepintas Lalu Jabatan Tenaga Kerja Sabah. Malaysia: Kementerian Sumber Manusia.

Jabatan Tenaga Kerja Sabah. (n.d.) Fungsi http://jtksbh.mohr.gov.my/index.php/en/about-us/functions, diakses 11 Juli 2016.

Jabatan Tenaga Kerja Sabah. (n.d.) Piagam Pelanggan http://jtksbh.mohr.gov.my/index.php/en/about-us/client-charter, diakses 11 Juli 2016.

Kedutaan Besar Republik Indonesia (KBRI) Kuala Lumpur. (2011). Laporan Tahunan Fungsi Ketenagakerjaan Tahun 2011. Kuala Lumpur.

Kedutaan Besar Republik Indonesia Kuala Lumpur. (2013). Data Tenaga Kerja Indonesia Tahun 2013. Kuala Lumpur: KBRI Kuala Lumpur.

Konsulat Republik Indonesia Tawau. (2014). Tugas Pokok dan Fungsi Konsulat Republik Indonesia Tawau. Tawau: KRI Tawau.

\section{Lembaga Swadaya Masyarakat dan Organisasi Internasional}

Buruhmigran.or.id. (2014) Mengenal Kondisi Organisasi dan Kelompok Buruh Migran di Malaysia http://pantaupjtki.buruhmigran.or.id/index.php/read/mengenal-kondisiorganisasi-dan-kelompok-buruh-migran-di-malaysia, diakses 19 Juli 2016.

Business for Social Responsibility. (2011) Improving Migrant Worker Recruitment in Indonesia http://www.bsr.org/reports/Improving_Migrant_Worker_Recruitment_in_Ind onesia.pdf, diakses 15 Juli 2016.

Department for International Development. (2009). Political Economy Analysis: How to Note - http://www.gsdrc.org/docs/open/po58.pdf, diakses 3 Maret 2016.

International Labour Organization. (2013). Laporan ILO: 10 Tahun Menangani Migrasi Kerja di Indonesia http://www.ilo.org/wcmsp5/groups/public/---asia/---ro-bangkok/---ilojakarta/documents/publication/wcms_213360.pdf.

International Organization for Migration. (2010). Migrasi Tenaga Kerja dari Indonesia: Gambaran Umum Migrasi Tenaga Kerja Indonesia di Beberapa Negara Tujuan di Asia dan Timur Tengah. Jakarta: IOM. 
LPK Korindo. (2012), Apa itu PPTKIS? Mari mengenal lebih jauh PPTKIS http://www.Ipkkorindo.com/2012/07/apa-itu-pptkismari-mengenal-lebihjauh.html, diakses 11 Juli 2016.

Pusat Sumber Daya Buruh Migran. (2015). Pekerja Perkebunan Sawit Indonesia dan Malaysia Makin Termarjinalkan http://buruhmigran.or.id/2015/03/24/pekerjaperkebunansawitindonesiadan malaysiamakintermarjinalkan/, diakses 2 Maret 2016.

\section{Karya Tulis IImiah}

Ardiyanto, Nur Angga. (2013). Kajian Migrasi dan Penghidupan Tenaga Kerja asal Indonesia di Kampung Pandan dalam Ampang Jaya Malaysia. Skripsi. Universitas Gadjah Mada.

Bertone, Maria Paola dan Sophie Witter. (2015). An exploration of the political economy dynamics shaping health worker incentives in three districts in Sierra Leone dalam Jurnal Social Science and Medicine (2015).

Hasibuan, Desi Auliani. (2011). Kebijakan Politik Pemerintah Susilo Bambang Yudhoyono Mengenai Hak Asasi Manusia (HAM) Tahun 20042009 (Studi Analisis Mengenai TKI yang Bekerja di Malaysia). Skripsi, Universitas Sumatera Utara.

Husna, Faizah Khotimatul. (2013). Kajian Kebijakan Pemerintah dalam Penempatan dan Perlindungan Tenaga Kerja Indonesia. Tesis. Universitas Gadjah Mada.

Islam, M.R. (2013). 'Partnership Research Between Malaysia and Indonesia : A Case of Labor Welfare'. Social Research Reports, Vol. 25, 2013.

Kardina. (2015). Pelanggaran Malaysia terhadap Standar HAM Convention on the Elimination of All Forms of Discrimination Against Women dalam Isu Kekerasan Migrant Domestic Worker Indonesia. Tesis. Universitas Gadjah Mada.

Kaur, Amarjit. (2005). Indonesian migrant workers in Malaysia: from preferred migrants to 'last to be hired' workers dalam Jurnal Review of Indonesian and Malaysian Affairs, Vol. 39 No. 2 (2005).

Masrie, Aspiannor. (2015). Analisis Kebijakan Susilo Bambang Yudhoyono dalam Menangani Masalah Tenaga Kerja Indonesia di Malaysia dalam Perspektif Ekonomi Politik. Tesis. Universitas Hasanuddin. 
Nasir Badu, Muhammad (ed.). (2015). Proceeding of International Seminar Democracy and Election: Solution for Establishing Good Governance. Yogyakarta: LeutikaBooks.

Rasyid, Abd. (2013). Fungsi dan Tugas Balai Pelayanan, Penempatan dan Perlindungan Tenaga Kerja Indonesia (BP3TKI) di Kota Makassar. Skripsi. Universitas Hasanuddin.

Susilowati, Indah, Mudji Rahardjo dan Waridin. (2001). Analisis Masalah Sosial, Politik dan Ekonomi pada Migrasi Tenaga Kerja Indonesia ke Luar Negeri. Laporan Penelitian DCRG. Universitas Diponegoro.

Zulfikar, Achmad, Suleman, dan Aan Febriadi. (2013). Penguatan Kapasitas Tenaga Kerja Internasional Indonesia dalam Aspek Etika dan Hukum di Kalangan Penyalur Jasa TKI di Yogyakarta. Program Kreativitas Mahasiswa-Penelitian Didanai DIKTI Tahun 2013, Universitas Muhammadiyah Yogyakarta.

Zulfikar, Achmad. (2013). Alasan Pemerintah Indonesia Meratifikasi Konvensi Internasional Perlindungan Hak Pekerja Migran Tahun 2012. Skripsi. Universitas Muhammadiyah Yogyakarta.

Zulfikar, Achmad. (2015). Rasionalitas Ekonomi Politik dalam Ratifikasi Konvensi Internasional Perlindungan Hak Pekerja Migran Tahun 2012. Jurnal The Politics Vol. 1 No. 1 Januari 2015. Makassar: Magister IImu Politik Universitas Hasanuddin.

\section{Wawancara}

Wawancara dengan Prakoso Wicaksono, Fungsi Ekonomi dan Protokol Kekonsuleran/Vice Consul KRI Tawau, 24 Mei 2016 di Kantor KRI Tawau.

Wawancara dengan Dian Ratri Astuti, Kepala Kanselerai/Fungsi Pensosbud KRI Tawau, 24 Mei 2016 di Kantor KRI Tawau.

Wawancara dengan Dr. Syamsi Alang, M.M., Koordinator Fungsional Pengantar Kerja Dinas Tenaga Kerja dan Transmigrasi Provinsi Sulawesi Selatan, 4 April 2016 di Kantor Disnakertrans Prov. Sulsel, Makassar.

Wawancara dengan Andi Iskandar, Kepala Seksi Perluasan Kerja, Dinas Tenaga Kerja Kota Makassar, 29 Maret 2016 di Kantor Disnaker Kota Makassar.

Wawancara dengan Mustamin Raga, Disnakersostrans Kabupaten Gowa, 22 April 2016 di Kompleks Kantor Bupati Gowa.

Wawancara dengan Yusran, S.Pd., Kepala Bidang Penempatan Tenaga Kerja, Disnaker Kota Pare-Pare, 31 Maret 2016 di Kantor Disnaker Kota Pare-Pare. 
Wawancara dengan Dr. Syahrul Yasin Limpo, S.H., M.H., M.Si., Gubernur Sulawesi Selatan, 20 Mei 2016 di Jakarta,

Wawancara dengan Andi Nagauleng, S.E., Direktur Utama PT. Amalindo Bhakti Persada, 24 Maret 2016 di Pare-Pare.

Wawancara dengan Mustaslifah binti Mostyn, Bagian Pengurusan Agensi Pekerjaan Mospia, 25 Mei 2016 di Tawau, Malaysia.

Wawancara dengan Tenri Ulleng, S.S., M.Pd., Kepala Seksi Penyiapan Penempatan BP3TKI Makassar, 30 Desember 2015 di Kantor BP3TKI Makassar

Wawancara dengan Mike Verawati, Project Officer Advokasi Buruh Migran berbasis Teknologi, 18 Mei 2016 di Jakarta.

Wawancara dengan Krishna Djelani, Kepala Subdirektorat Pengawasan Kekonsuleran, Direktorat Perlindungan WNI dan BHI Kementerian Luar Negeri RI, 13 Mei 2016 di Kompleks Kemlu RI, Jakarta.

Wawancara dengan Sigit Triwibawanto, Kepala Seksi Perlindungan dan Pemberdayaan BP3TKI Nunukan, 23 Mei 2016 di Kantor BP3TKI Nunukan

Wawancara dengan Drs. H. Andi Marzuki Wadeng, Ketua Komisi E DPRD Provinsi Sulawesi Selatan, 25 April 2016 di Gedung DPRD Provinsi Sulsel

Wawancara dengan Suhaili bin Ismail, Senior Assistant Director, Pejabat Tenaga Kerja Tawau, Jabatan Tenaga Kerja Sabah, Kementerian Sumber Manusia, Malaysia, 27 Mei 2016 di Wisma Persekutuan Tawau.

\section{Media Massa}

\section{Media Cetak}

Lalu M. Iqbal. "Kontribusi PMI terhadap Kemajuan Malaysia: Perlu Diimbangi dengan Perlindungan dan Kesejahteraan" Tabloid Diplomasi No. 85 Tahun VIII 15 Februari-14 Maret 2015.

\section{Media Online}

Antara News. (2013). Kemlu bentuk 11 Kelompok Kerja Kongres Diaspora - http://www.antaranews.com/berita/384634/kemlu-bentuk-11-kelompokkerja-kongres-diaspora, diakses 22 November 2015.

Hidayat. (2012). Kisah Pilu Nasib Para Pekerja Sawit http://www.kompasiana.com/sangia/kisah-pilu-nasib-para-pekerjasawit_550dfea0813311b52cbc60bc, diakses 10 Agustus 2016. 
Detik Finance. (2014). Pekerja Perkebunan di Malaysia Didominasi TKI, Ini Alasannya -

http://finance.detik.com/read/2014/11/08/173138/2742842/4/pekerjaperkebunan-di-malaysia-didominasi-tki-ini-alasannya, diakses 2 Maret 2016.

Harian Amanah. (2016). 74 TKI asal Sulsel "Adu Nasib" ke Sarawak http://amanah.alharamnews.com/post/1232/74-tki-sulsel-adu-nasib-kesarawak, diakses 2 Maret 2016.

Liputan 6. (2014). Upah Tinggi Bukan Alasan Utama TKI Cari Kerja di Malaysia - http://bisnis.liputan6.com/read/2042867/upah-tinggi-bukanalasan-utama-tki-cari-kerja-di-malaysia, diakses 1 Maret 2016.

Suara Pembaruan. (2013). Remitansi TKI Tahun 2013 Capai Rp. 81,34 Triliun - http://sp.beritasatu.com/ekonomidanbisnis/remitansi-tki-tahun2013-capai-rp-8134-triliun/47110, diakses 22 November 2015.

Guru PPKN. (n.d.) Fungsi Lembaga Swadaya Masyarakat http://guruppkn.com/fungsi-lembaga-swadaya-masyarakat, diakses 18 Juli 2016. 